\title{
NOVA CONFIGURAÇÃO DE BIOFILTRO AERADO SUBMERSO UTILIZADO NO PÓS-TRATAMENTO DO EFLUENTE DE REATOR UASB
}

Tese de doutorado apresentada à Escola de Engenharia de São Carlos da Universidade de São Paulo, como parte dos requisitos para obtenção do título de Doutor em Engenharia Civil - Hidráulica e Saneamento.

Orientador:

Prof. Dr. Luiz Antônio Daniel 
AUTORIZO A REPRODUCAO E DVULGA CAO TOTAL OU PARCIAL DESTE TRABALHO, POR OUALOUER MEIO CONVENCIONAL OU ELETRONICO, PARA FING DE ESTUDO E PESOUISA, DESDE QUE CITADA A FONTE.

Ficha catalográfica preparada pda So,jōo de Tratamento da Informagio do Servigo de Biblioteca - EESCUSP

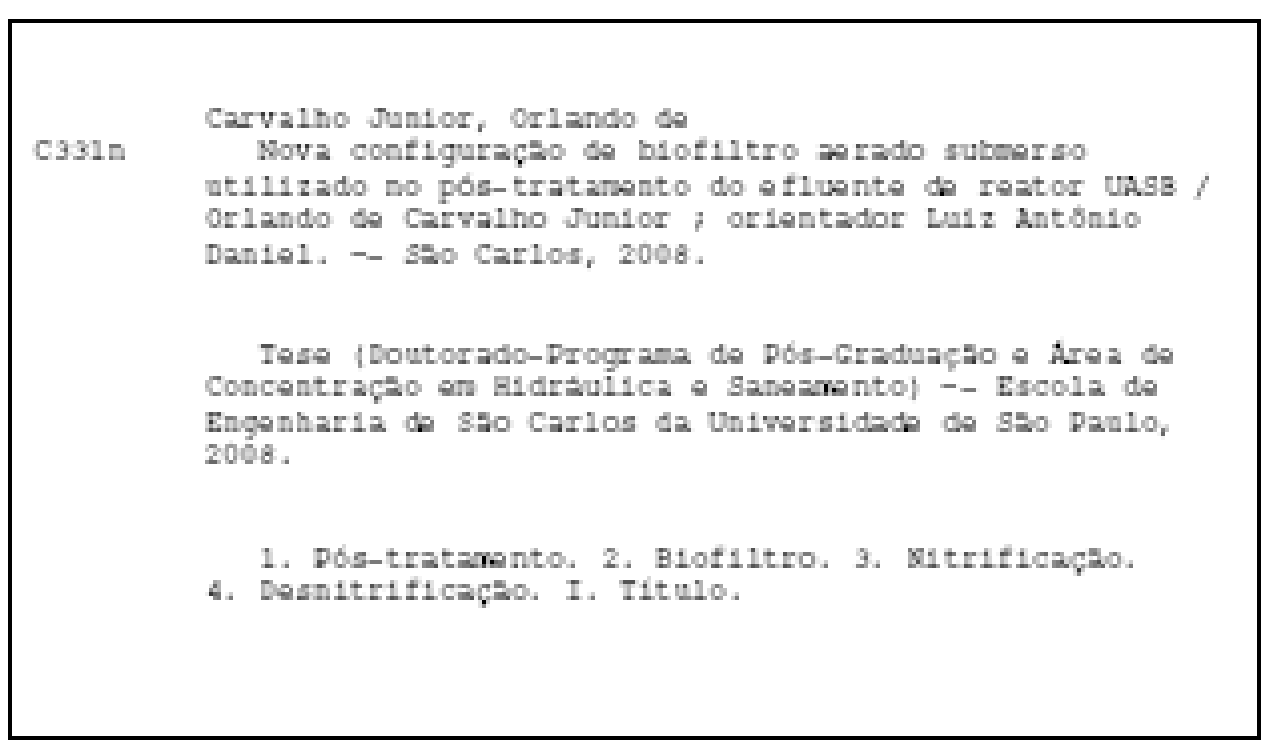


Candidato: Engenheiro ORLANDO DE CARVALHO JUNIOR

Tese defendida e julgada em 15/12/2008 perante a Comissão Julgadora:

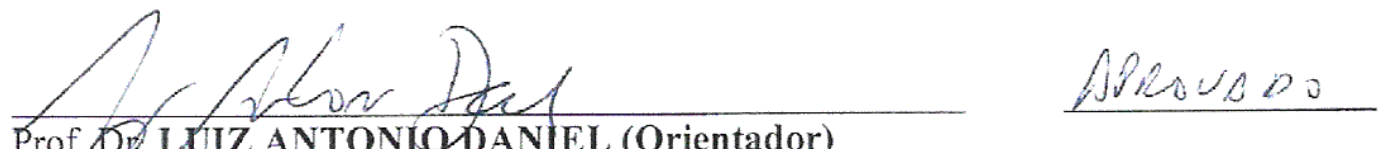

Prof. D0. LUIZ ANTONIO DANIEL (Orientador)

(Escola de Engenharia de São Carlos/USP)

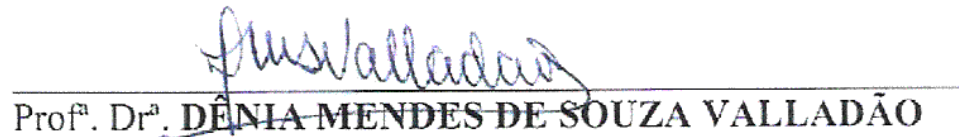

Apucuade

(Universidade do Estado do Mato Grosso/UNEMAT)

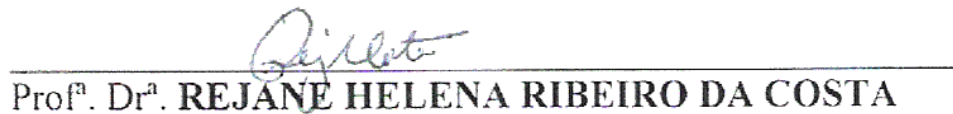

Aproviado

(Universidade Federal de Santa Catarina/UFSC)

$\frac{D b \int b e n}{\text { Prof. Dr. DIB GEBARA }}$ Apnovdo

Wána DRz.Comianme

Dr ${ }^{n}$. MÁRCIA HELENA ZAMARIOLLI DAMIANOVIC

Aprovitao

(Pós-Doutoranda/UFSCar)

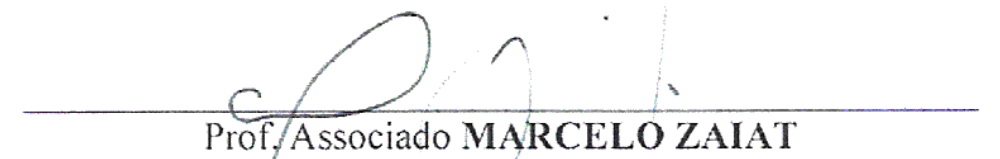

Coordenador do Prograna de Pós-Graduação em

Engenharia (Hidráulica e Saneamento)

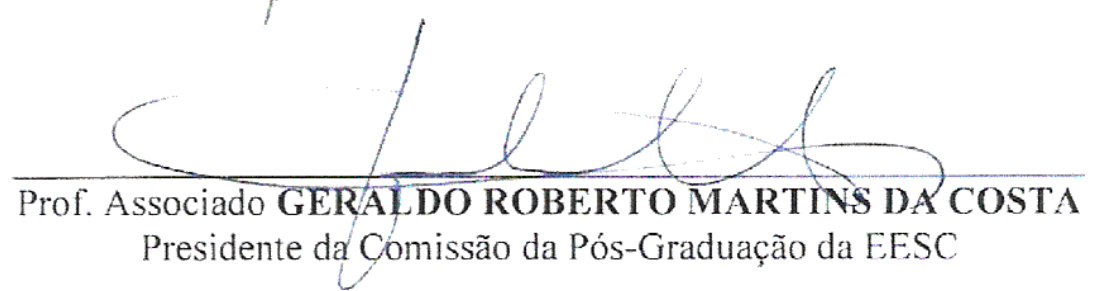




\section{Resumo}

CARVALHO JR., O. (2008). Nova configuração de biofiltro aerado submerso utilizado no pós-tratamento do efluente de reator UASB. Tese (Doutorado) - Escola de Engenharia de São Carlos, 2008.

O principal objetivo desse trabalho foi desenvolver uma nova configuração de biofiltro aerado submerso utilizado no pós-tratamento do efluente de reator UASB, capaz de realizar nitrificação e desnitrificação em um único sistema. Em busca de bases operacionais dessa nova configuração, a pesquisa foi inicialmente conduzida com três reatores seqüenciais. Esses reatores foram dispostos nas seqüências I e II, respectivamente. Os resultados obtidos com esses sistemas seqüenciais levaram a concepção do projeto da nova configuração do biofiltro proposto (BF definitivo). Os resultados da seqüência I mostraram alto potencial para conversão de nitrogênio amoniacal e total, e também alta eficiência na remoção da matéria orgânica carbonácea. Esse sistema, porém, não apresentou potencial para desnitrificação. Na seqüência II foi realizada recirculação entre dois reatores do sistema (anóxico e aeróbio) para aumento de tal potencial. O maior potencial de desnitrificação, nessa seqüência, foi observado para razão de recirculação, $\mathrm{R}_{\mathrm{c}}$, igual a 2,65 e com o uso de $40 \%$, em volume, de esgoto sanitário bruto como fonte de carbono. Sob essas condições operacionais, para concentração média afluente ao sistema igual a 33,74 mg de $\mathrm{N}-\mathrm{NH}_{3} / \mathrm{L}$ as concentrações efluentes médias de $\mathrm{N}-\mathrm{NH}_{3}, \mathrm{~N}_{-} \mathrm{NO}_{2}{ }^{-} \mathrm{e} \mathrm{N}^{-\mathrm{NO}_{3}}{ }^{-}$foram, respectivamente, iguais a 0,16 , 0,0026 e 9,72 mg/L. Os resultados do BF definitivo mostraram que a nova configuração proposta é viável como unidade de pós-tratamento de efluente de reator UASB, promovendo nitrificação e desnitrificação em um único sistema, além de alta eficiência de remoção da matéria orgânica. Em todas as fases dessa pesquisa, praticamente, todos os resultados obtidos atenderam ao padrão de lançamento de nitrogênio amoniacal estabelecido pela legislação ambiental.

Palavras chave: pós-tratamento, biofiltro, nitrificação, desnitrificação. 


\section{Abstract}

CARVALHO JR., O. (2008). New configuration of submerged aerated biofilter used in the effluent UASB reactor post-treatment. Ph. D Thesis - Escola de Engenharia de São Carlos, 2008.

The main objective of this work was developing a new configuration of submerged aerated biofilter used in UASB reactor post-treatment, with nitrification and denitrification in a single system. Searching operational bases of this new configuration, this research was initially driven by three sequential reactors. These reactors were arranged in the sequences I and II, respectively. The results obtained with these sequential systems took the conception of the project of the new configuration of the proposed biofilter (definitive BF). The results of the sequence I showed high ammoniacal and total nitrogen conversion potential, and also high carbonaceous organic matter removal efficiency. This system, however, not presented potential for denitrification. In the sequence II recirculation between two reactors (anoxic and aerated) of the system was made for such potential increasing. The higher denitrification potential, in this sequence, was observed with recirculation reason, $R_{c}$, equal to 2,65 and using $40 \%$, in volume, of raw sanitary sewage as carbon source. Under these operational conditions, for average affluent concentration of 33,74 mg of N-NH3/L the average effluent concentrations of $\mathrm{N}-\mathrm{NH}_{3}, \mathrm{~N}_{-} \mathrm{NO}_{2}{ }^{-}$e $\mathrm{N}_{-\mathrm{NO}_{3}}^{-}$were, respectively, equal to $0,16,0,0026$ and $9,72 \mathrm{mg} / \mathrm{L}$. The results of the definitive BF showed that the new proposed configuration is feasible as effluent UASB post-treatment unity, with nitrification and denitrification in a single system, besides high organic matter removal efficiency. Practically in all the phases of this research, all the results obtained attended to the launch standard of ammoniacal nitrogen established by the environmental legislation.

Key words: post-treatment, biofilter, nitrification, denitrification. 
"Os jovens se cansam e se fatigam, e os moços de exaustos caem, mas os que esperam no SENHOR renovam as suas forças, sobem com asas como águias, correm e não se cansam, caminham e não se fatigam".Isaías 40:30-31. 
Este trabalho é dedicado ao

Senhor Jesus, à minha amada esposa Karin e ao meu querido filho Daniel. 


\section{Agradecimentos}

A Deus, em primeiro lugar, pelo dom da vida e constante apoio nas horas difíceis.

À minha amada esposa Karin, pelo encorajamento, amor e carinho doados diariamente.

A CAPES (Coordenação de Aperfeiçoamento de Pessoal de Nível Superior) pela concessão da Bolsa de Doutorado.

Ao Professor Luiz Antonio Daniel pela bondade e excelente orientação concedidas ao longo do desenvolvimento dessa pesquisa.

Ao Professor Dib Gebara por me encorajar a seguir a carreira acadêmica.

Aos técnicos do Laboratório de Saneamento Júlio, Paulo, Cidinha e Juliana.

À Doutora Eloiza Pozzi Gianotti pela ajuda prestada durante os exames microbiológicos.

A todos os funcionários do Departamento de Hidráulica e Saneamento especialmente à Rose, pela alegria e atenção constantes; as secretárias Sá e Pavi.

Ao Roberto Bérgamo pelo apoio técnico prestado.

Aos meus pais Orlando e Fátima.

As minhas amadas irmãs, Érika, Fabíola e Fabiana.

Aos meus sogros Francisca e José Luiz.

Aos amigos, Madison e Anelise Pott, Lik e Simone Barra, Elen e Vinny, Paulo e Raquel Escher, André e Tenille Christoforo e Dênia M. S. Valladão.

Ao amigo Ricardo Galavoti pelo apoio, fundamental para conclusão desse trabalho.

Aos meus alunos da primeira turma de engenharia civil da UNEMAT (Universidade do Estado de Mato Grosso) e professores do departamento de engenharia civil, pelo apoio e compreensão prestados no período em que esse trabalho foi escrito.

E a todos que direta ou indiretamente contribuíram para a conclusão desse trabalho. 


\section{Lista de figuras}

Figura 2.1 - Esquema de um Biofilme....................................................................6

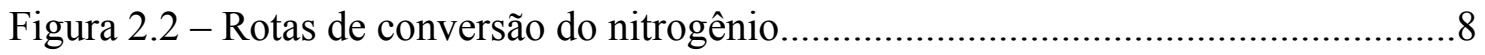

Figura 2.3 - Esquema da estratificação das camadas do biofilme no processo SND.....14

Figura 2.4 - Sistema pós-anóxico de lodos ativados para remoção de $\mathrm{N}-\mathrm{NH}_{3} \ldots \ldots \ldots \ldots \ldots . . . .15$

Figura 2.5 - Sistema pré-anóxico de lodos ativados para remoção de $\mathrm{N}-\mathrm{NH}_{3} \ldots \ldots \ldots \ldots \ldots . . . .15$

Figura 2.6 - Sistema tipo Bardenpho de lodos ativados para remoção de $\mathrm{N}^{-\mathrm{NH}_{3} \ldots \ldots \ldots . . .16}$

Figura 2.7 - Esquema de um biofiltro aerado submerso................................................17

Figura 2.8 - Esquema da associação UASB + BF......................................................19

Figura 2.9 - Esquema do biofiltro utilizado por ARAÚJO JR. (2006)..........................20

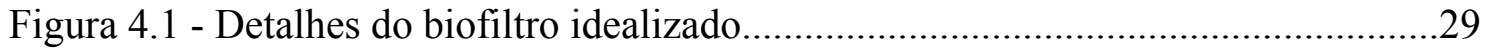

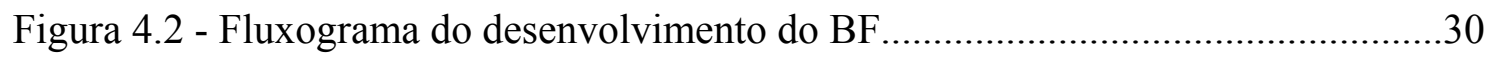

Figura 4.3 - Bancada experimental e esquema de funcionamento dos reatores na Seqüência I.

Figuras 4.4 (a) e (b)- Fotografia do reator UASB e da sala na qual os reatores estão instalados.

Figura 4.5 - Bancada experimental e esquema de funcionamento dos reatores na Seqüência II. 37

Figura 4.6 - Fotografia dos reatores empregados nas duas seqüências da etapa I..........39

Figura 4.7 - Representação esquemática do Biofiltro Piloto...........................................40

Figura 4.8 - Fotografias da montagem do Biofiltro Piloto.............................................42

Figura 4.9 - Fotografia do material suporte empregado na pesquisa..............................43

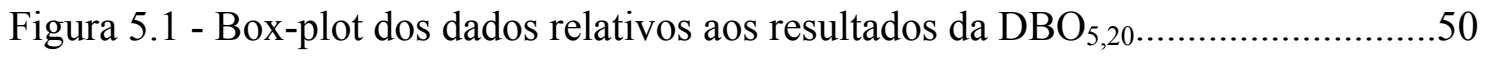

Figura $5.2-\mathrm{DBO}_{5,20}$ de entrada e saída do sistema de reatores operados na seqüência I........

Figura 5.3 - Eficiência total de remoção de $\mathrm{DBO}_{5,20}$ durante o período de operação da seqüência I.

Figura 5.4 - Relação Correlação entre as cargas orgânicas volumétricas aplicadas de removidas .53

Figura 5.5 - Box-plot dos dados relativos aos resultados da DQO. .55 
Figura 5.6 - Variação da DQO afluente e efluente do sistema durante o período de operação correspondente a seqüência I 56

Figura 5.7 - Variação das concentrações de NTK durante a operação da seqüência I...59 Figura 5.8 - Box-plot dos dados relativos aos resultados de NTK para a seqüência I....60 Figura 5.9 - Box-plot dos dados relativos aos resultados de $\mathrm{N}-\mathrm{NH}_{3}$ para a seqüência I.......

Figura 5.10 - Relação entre as cargas volumétricas aplicadas e removidas em $\mathrm{N}^{-\mathrm{NH}_{3}}$ na seqüência I.

Figura 5.11 - Variação das concentrações de $\mathrm{N}-\mathrm{NH}_{3}$ durante a operação da seqüências I... .62

Figura 5.12 - Box-plot dos dados relativos aos resultados de nitrificação e desnitificação para a seqüência I .65

Figura 5.13 - Box-plot da relação $\mathrm{C} / \mathrm{N}$ das amostras afluentes aos reatores $\mathrm{R} 2$ e R3 da seqüência I..... .66

Figura 5.14 - Box-plot dos resultados referentes aos parâmetros pH e alcalinidade total. .68

Figura 5.15 - Box-plot da relação SSV/SST para amostras coletadas na seqüência I....70

Figura 5.16 - Box-plot da relação SV/ST dos resultados obtidos na seqüência I............72

Figura 5.17 - Box-plot da relação SF/SV dos resultados obtidos na seqüência I............74

Figura 5.19 - Box-plot referente à DQO para resultados obtidos na etapa III................75

Figura 5.20 - Box-plot do parâmetro NTK para resultados obtidos na etapa I, seq. II. .78

Figura 5.21 - Box-plot do parâmetro NTK para resultados obtidos na etapa II, seq.

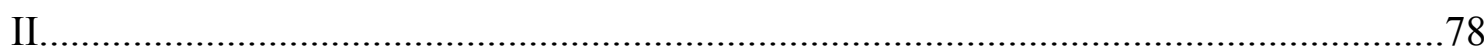

Figura 5.22 - Box-plot do parâmetro NTK para resultados obtidos na etapa III,

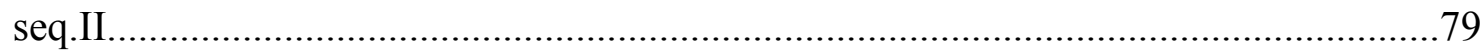

Figura 5.23 - Box-plot do parâmetro $\mathrm{N}^{-\mathrm{NH}_{3}}$ para resultados obtidos na etapa I, seq. II. .82

Figura 5.24 - Box-plot do parâmetro $\mathrm{N}-\mathrm{NH}_{3}$ para resultados obtidos na etapa II, seq. II.

Figura 5.25 - Box-plot do parâmetro $\mathrm{N}^{-\mathrm{NH}_{3}}$ para resultados obtidos na etapa III, seq.II.

Figura 5.26 - Evolução do potencial de desnitrificação ao longo das etapas da seq. II. 
Figura 5.27 - Box-plot das relações DQO/N observadas na seqüência I e na etapa III

Figura 5.28 - Box-plot dos resultados de pH e alcalinidade total da etapa I, sequência II.

Figura 5.29 - Box-plot dos resultados de $\mathrm{pH}$ e alcalinidade total da etapa II.................92

Figura 5.30 - Box-plot dos resultados de pH e alcalinidade total da etapa III................94

Figura 5.31 - Correlação entre COVa e COVr em DQO para o Biofiltro Piloto............95

Figura 5.32 - Variação temporal da DQO durante a operação do Biofiltro Piloto..........96

Figura 5.33 - Box-plot do parâmetro NTK para resultados obtidos na operação do Biofiltro Piloto...

Figura 5.34 - Box-plot do parâmetro $\mathrm{N}-\mathrm{NH}_{3}$ para resultados obtidos na operação do Biofiltro Piloto. 98

Figura 5.35 - Box-plot dos parâmetros $\mathrm{N}-\mathrm{NH}_{3}, \mathrm{~N}_{-} \mathrm{NO}_{2}{ }^{-}$e N-NO${ }_{3}^{-}$obtidos na operação do Biofiltro Piloto. 100

Figura 5.36 - Variação temporal da alcalinidade total durante a operação do Biofiltro Piloto. 102

Figura 5.37 - Box-plot dos resultados da alcalinidade total obtidos na operação do Biofiltro Piloto. 102

Figura 5.38 - Box-plot dos valores do pH obtidos na operação do Biofiltro Piloto.......103 Figura 5.39 - Variação temporal dos valores do pH obtidos na operação do Biofiltro Piloto..... 104

Figura 5.40 - Box-plot dos valores de ST, SF e SV obtidos na operação do Biofiltro Piloto. 106

Figura 5.41 - Box-plot dos valores de SDT, SDF e SDV obtidos na operação do Biofiltro Piloto. 107

Figura 5.42 - Box-plot das relações SV/ST e SDV/SDT obtidas na operação do Biofiltro Piloto. 107

Figura 5.43 - Box-plot da relação SF/SV obtida na operação do Biofiltro Piloto. 108

Figura 5.44 - Enquadramento do efluente produzido pelo sistema ao padrão de lançamento estabelecido pela resolução CONAMA 357/05.

Figura 5.45 - Microscopia óptica comum do lodo coletado na etapa III da seqüência II: microrganismos ciliados fixos semelhantes a Epystilis sp.

Figura 5.46 - Microscopia óptica comum do lodo coletado na etapa III da seqüência II: microrganismo filamentoso semelhante à Beggiatoa $\mathrm{sp}$. 
Figura 5.47 - Microscopia óptica comum do lodo coletado na etapa III da seqüência II: microrganismo Metazoário Nematóide.

Figura 5.48 - Microscopia óptica comum do lodo coletado na etapa III da seqüência II: microrganismo Metazoário Rotífero.

Figura 5.49 - Microscopia óptica comum do lodo coletado na etapa III da seqüência II: microrganismo Metazoário Ácaro 


\section{Lista de tabelas}

Tabela 2.1 - Influência das condições de operação sobre os fatores de formação do biofilme em sistemas de crescimento aderido.

Tabela 2.2 - Valores de $\mathrm{pH}$, temperatura e $\mathrm{OD}$, limitantes para nitrificação. .10

Tabela 2.3- Classificação dos corpos d'água e respectivos usos preponderantes de acordo com a Resolução CONAMA n 357 de 17 de Março de 2005. .23

Tabela 2.4 - Padrões para lançamento de efluentes.

Tabela 2.5 - Padrões de lançamento e/ou potabilidade estabelecidos por órgãos ambientais do Brasil e de outros países. .25

Tabela 4.1 - Principais características dos reatores utilizados na sequência I. 31

Tabela 4.2 - Principais características dos reatores utilizados na sequência II. .36

Tabela 4.3 - Condições de operação dos reatores utilizados em cada etapa da seqüência II..

Tabela 4.4 - Principais características dos reatores utilizados na composição do Biofiltro Piloto...... . .41

Tabela 4.5 - Rotina de ensaios para monitoramento da eficiência na seqüência I 45

Tabela 4.6 - Rotina de ensaios para monitoramento da eficiência na seqüência II.........45 Tabela 4.7 - Rotina de ensaios para monitoramento da eficiência no Biofiltro Piloto....45 Tabela 5.1 - Valores mínimos, máximo, média aritmética e eficiência de remoção de $\mathrm{DBO}_{5,20}$ para os resultados obtidos na seqüência I.

Tabela 5.2 - Valores mínimos, máximos, média aritmética e número de amostras analisadas das cargas orgânicas volumétricas aplicada $\left(\mathrm{COV}_{\mathrm{a}}\right)$ e removida $\left(\mathrm{COV}_{\mathrm{r}}\right)$ do sistema de reatores operados na seqüência I.

Tabela 5.3 - Valores mínimos, máximo, média artimética e eficiência de remoção de DQO para amostras coletadas na seqüência I.

Tabela 5.4 Valores mínimo, máximo, média aritmética e número de amostras analisadas para a relação DBO/DQO durante operação da seqüência I.

Tabela 5.5 - Valores mínimo, máximo, média aritmética e eficiência total do sistema em relação a NTK para amostras analisadas, na seqüência I, e número de amostras com concentração não detectada. .58

Tabela 5.6 - Valores médio, mínimo e máximo de $\mathrm{N}^{-\mathrm{NH}_{3}}$ as amostras analisadas, na seqüência I, e número de amostras com concentração não detectada. 
Tabela 5.7 - Valores mínimo, máximo, média aritmética e número de amostras

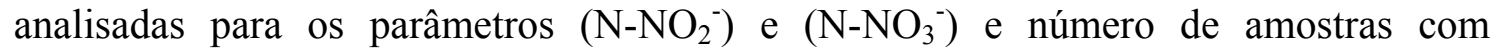
concentração de nitrito menor que $0,01 \mathrm{mg} / \mathrm{L}$.

Tabela 5.8 - Valores médio, mínimo, máximo e número de amostras analisadas para as variáveis $\mathrm{pH}$ e alcalinidade total em $\mathrm{mg}$ de $\mathrm{CaCO}_{3} / \mathrm{L}$

Tabela 5.9 - Valores médio, mínimo, máximo e número de amostras analisadas para os parâmetros SST, SSF, SSV e SSV/SST.

Tabela 5.10 - Valores médio, mínimo, máximo e numero de amostras analisadas para os parâmetros ST, SF, SV e SV/ST.

Tabela 5.11-Valores médio, mínimo, máximo e eficiência total de remoção do sistema em COT para amostras analisadas na seqüência II, etapa I.

Tabela 5.12-Valores médio, mínimo, máximo e eficiência total de remoção de remoção do sistema em DQO para amostras analisadas na seqüência II, etapa III. .75 Tabela 5.13 - Valores mínimo, máximo, média aritmética e eficiência total do sistema em relação a NTK para amostras analisadas, na seqüência II - etapa I, e número de amostras com concentração não detectada.

Tabela 5.14 - Valores médio, mínimo, máximo e eficiência total do sistema em relação a NTK para amostras analisadas, na seqüência II - etapa II, e número de amostras com concentração não detectada.. .77

Tabela 5.15 - Valores médio, mínimo, máximo e eficiência total do sistema em relação a NTK para amostras analisadas, na seqüência II - etapa III, e número de amostras com concentração não detectada.

Tabela 5.16-Valores mínimo, máximo, média aritmética e eficiência total do sistema em relação a $\mathrm{N}_{-} \mathrm{NH}_{3}$ para amostras analisadas, na seqüência II - etapa I, e número de amostras com concentração não detectada... .80

Tabela 5.17-Valores mínimo, máximo, média aritmética e eficiência total do sistema em relação a $\mathrm{N}-\mathrm{NH}_{3}$ para amostras analisadas, na seqüência II - etapa II, e número de amostras com concentração não detectada......

Tabela 5.18-Valores mínimo, máximo, média aritmética e eficiência total do sistema em relação a $\mathrm{N}_{-} \mathrm{NH}_{3}$ para amostras analisadas, na seqüência II - etapa III, e número de amostras com concentração não detectada.. .81

Tabela 5.19 - Valores mínimo, máximo, média aritmética e número de amostras

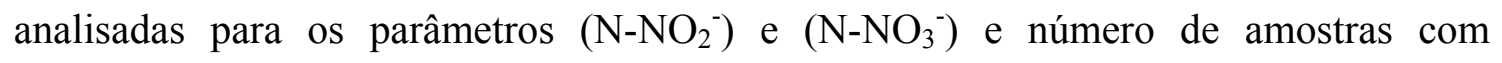
concentração de nitrito menor que $0,01 \mathrm{mg} / \mathrm{L}$ encontrados na etapa I, sequência II......84 
Tabela 5.20 - Valores mínimo, máximo, média aritmética, número de amostras

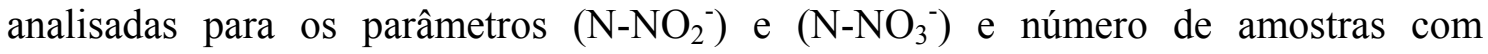
concentração de nitrito menor que $0,01 \mathrm{mg} / \mathrm{L}$ encontrados na etapa II, sequência II.....85 Tabela 5.21 - Valores mínimo, máximo, média aritmética e número de amostras analisadas para os parâmetros $\left(\mathrm{N}^{-\mathrm{NO}_{2}}{ }^{-}\right)$e $\left(\mathrm{N}^{-\mathrm{NO}_{3}}{ }^{-}\right)$e número de amostras com concentração de nitrito menor que $0,01 \mathrm{mg} / \mathrm{L}$ encontrados na etapa III, sequência II....86 Tabela 5.22 - Valores, mínimo, máximo, média aritmética e número de amostras analisadas para as variáveis $\mathrm{pH}$ e alcalinidade total em $\mathrm{mg}$ de $\mathrm{CaCO}_{3} / \mathrm{L}$ analisados na etapa I, sequência II.

Tabela 5.23 - Valores mínimo, máximo, média aritmética e número de amostras analisadas para as variáveis $\mathrm{pH}$ e alcalinidade total em mg de $\mathrm{CaCO}_{3} / \mathrm{L}$ analisados na etapa II

Tabela 5.24 - Valores, mínimo, máximo, média aritmética e número de amostras analisadas para os parâmetros $\mathrm{pH}$ e alcalinidade total em $\mathrm{mg}$ de $\mathrm{CaCO}_{3} / \mathrm{L}$ analisados na etapa III.

Tabela 5.25 - Valores mínimo, máximo, média aritmética de DQO, COVa e COVr das amostras analisadas na operação do Biofiltro Piloto.

Tabela 5.26 - Valores mínimo, máximo, média aritmética e eficiência total do sistema na conversão de NTK para amostras analisadas, na operação do Biofiltro Piloto

Tabela 5.27 - Valores mínimo, máximo, média aritmética e eficiência total do sistema na conversão de $\mathrm{N}-\mathrm{NH}_{3}$ para amostras analisadas, na operação do Biofiltro Piloto.......98 Tabela 5.28 - Valores médio, mínimo, máximo e números de amostras analisadas para os parâmetros $\mathrm{N}^{-\mathrm{NO}_{2}}{ }^{-}$e $\mathrm{N}-\mathrm{NO}_{3}{ }^{-}$encontrados durante a operação do Biofiltro Piloto..99 Tabela 5.29 - Valores médio, mínimo, máximo e número de amostras analisadas para os parâmetros $\mathrm{pH}$ e alcalinidade total analisados na operação do Biofiltro Piloto. 101 Tabela 5.30 - Valores médio, mínimo, máximo e numero de amostras analisadas para os parâmetros ST, SF, SV, SDT, SDF, SDV e relações SV/ST, SF/SV e SDV/SDT...105 


\section{Lista de abreviaturas e Símbolos}

BF: $\quad$ Biofiltro aerado submerso.

$\mathrm{CaCO}_{3}$ : $\quad$ Carbonato de Cálcio

$\mathrm{CV}_{\mathrm{a}}$ : $\quad$ Carga de nitrogênio amoniacal aplicada, $[\mathrm{M}]^{*}\left[\mathrm{~L}^{-3}\right]^{*}\left[\mathrm{~T}^{-1}\right]$

$\mathrm{CV}_{\mathrm{r}}$ : Carga de nitrogênio amoniacal removida, $[\mathrm{M}]^{*}\left[\mathrm{~L}^{-3}\right]^{*}\left[\mathrm{~T}^{-1}\right]$

$\mathrm{COV}_{\mathrm{a}}$ : Carga orgânica volumétrica aplicada, $[\mathrm{M}]^{*}\left[\mathrm{~L}^{-3}\right]^{*}\left[\mathrm{~T}^{-1}\right]$

$\mathrm{COV}_{\mathrm{r}}$ : $\quad$ Carga orgânica volumétrica removida, $[\mathrm{M}]^{*}\left[\mathrm{~L}^{-3}\right]^{*}\left[\mathrm{~T}^{-1}\right]$

CONAMA: Conselho Nacional do Meio Ambiente

$\mathrm{CO}_{2}$ : Gás carbônico

$\mathrm{DBO}_{5}$ : Demanda bioquímica de oxigênio após 5 dias de incubação a $20^{\circ} \mathrm{C}$

DQO: Demanda química de oxigênio para amostra bruta

DQO/N: Relação entre concentração de DQO e Nitrato

ETE: $\quad$ Estação de tratamento de esgoto

E (\%): $\quad$ Eficiência

Máx: $\quad$ Concentração máxima

Méd.: Média aritmética das concentrações

Mín.: $\quad$ Concentração mínima

$\mathrm{N}_{2}$ : Nitrogênio gasoso

$\mathrm{N}-\mathrm{NH}_{4}{ }^{+}$: $\quad$ Íon amônio

$\mathrm{N}-\mathrm{NO}_{2}^{-}:$Ín nitrito

$\mathrm{N}_{-} \mathrm{NO}_{3}^{-}:$Ílon nitrato

$\mathrm{N}_{-\mathrm{NH}_{3}}{ }^{-}: \quad$ Nitrogênio Amonical na forma gás amoníaco, $[\mathrm{M}]^{*}\left[\mathrm{~L}^{-3}\right]$

N-orgânico: Nitrogênio orgânico, $[\mathrm{M}]^{*}\left[\mathrm{~L}^{-3}\right]$

N- amoniacal: Nitrogênio Amoniacal, $[\mathrm{M}]^{*}\left[\mathrm{~L}^{-3}\right]$

$\mathrm{n}$ Número de amostras analisadas

NTK: $\quad$ Nitrogênio Total de Kjeldahl, $[\mathrm{M}]^{*}\left[\mathrm{~L}^{-3}\right]$

OD.: $\quad$ Oxigênio Dissolvido

pH: $\quad$ Potencial hidrogeniônico

$\mathrm{R}_{\mathrm{c}}$ : $\quad$ Razão de recirculação

ST: $\quad$ Sólidos totais, $[\mathrm{M}]^{*}\left[\mathrm{~L}^{-3}\right]$

STF: $\quad$ Sólidos totais fixos, $[\mathrm{M}]^{*}\left[\mathrm{~L}^{-3}\right]$ 
STV: $\quad$ Sólidos totais voláteis, $[\mathrm{M}]^{*}\left[\mathrm{~L}^{-3}\right]$

SST: $\quad$ Sólidos suspensos totais, $[\mathrm{M}]^{*}\left[\mathrm{~L}^{-3}\right]$

SSF: $\quad$ Sólidos suspensos fixos, $[\mathrm{M}]^{*}\left[\mathrm{~L}^{-3}\right]$

SSV: $\quad$ Sólidos suspensos voláteis, $[\mathrm{M}]^{*}\left[\mathrm{~L}^{-3}\right]$

SSD: $\quad$ Sólidos sedimentáveis em cone de Imhoff, $[\mathrm{M}]^{*}\left[\mathrm{~L}^{-3}\right]$

SDT: $\quad$ Sólidos dissolvidos totais, $[\mathrm{M}]^{*}\left[\mathrm{~L}^{-3}\right]$

SDF: $\quad$ Sólidos dissolvidos fixos, $[\mathrm{M}]^{*}\left[\mathrm{~L}^{-3}\right]$

SDV: $\quad$ Sólidos dissolvidos voláteis, $[\mathrm{M}]^{*}\left[\mathrm{~L}^{-3}\right]$

TDH: $\quad$ Tempo de detenção hidráulica

UASB: Upflow anaerobic slugde blanket - reator anaeróbio de fluxo ascendente com manta de lodo. 



\section{Sumário}

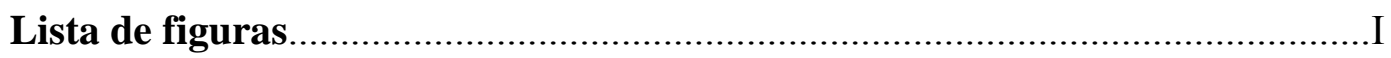

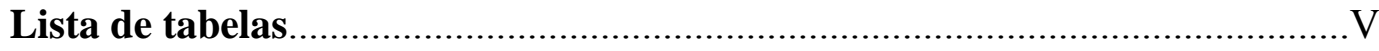

Lista de abreviaturas e símbolos................................................................. VIII

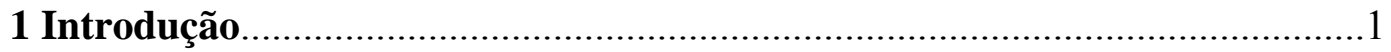

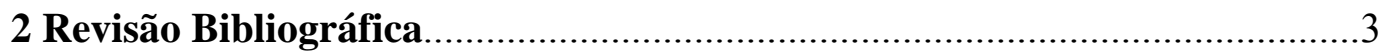

2.1 Microbiologia para tratamento de esgoto sanitário..................................

2.2 Biofilme em reatores de crescimento aderido ou imobilizado.................4

2.3 Remoção biológica do nitrogênio...........................................................

2.3.1 Nitrificação....................................................................

2.3.2Denitrificação.................................................................11

2.4 Sistemas utilizados para tratamento e/ou pós-tratamento de efluentes visando remoção de nitrogênio amoniacal..................................................15

2.5 Biofiltros aerados submersos utilizados para tratamento de águas

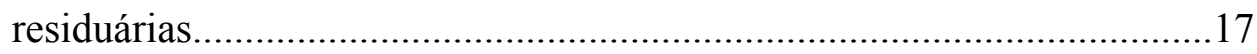

2.6 Padrões da legislação ambiental para lançamento de efluentes............22

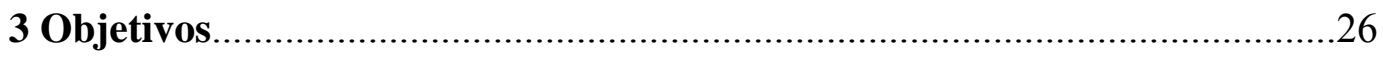

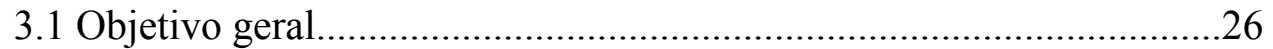

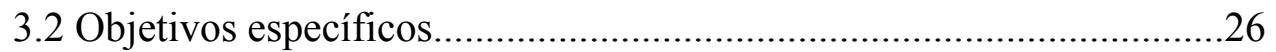

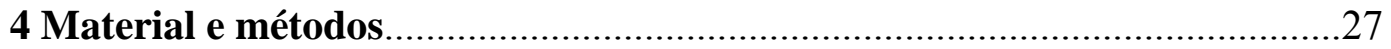

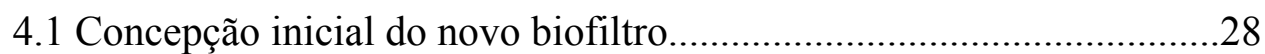

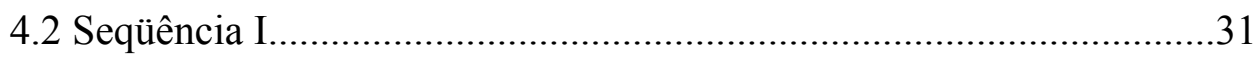

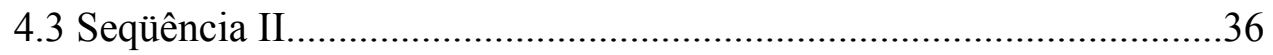

4.4 Configuração do Biofiltro Piloto...........................................................39

4.5 Rotina de operação e análises físico-químicas.........................................44

4.6 Dificuldades encontradas....................................................................46

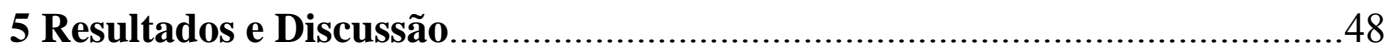

5.1 Seqüência I.......................................................................................49

5.1.1 Remoção de $\mathrm{DBO}_{5,20}$ e DQO....................................................

5.1.2 Remoção de Nitrogênio..........................................................57

5.1.3 Remoção de Sólidos...................................................................

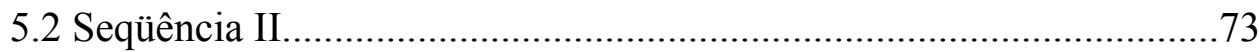


5.2.1 Remoção de carbono orgânico total (COT) e DQO..............73

5.2.2 Remoção de Nitrogênio..........................................................76

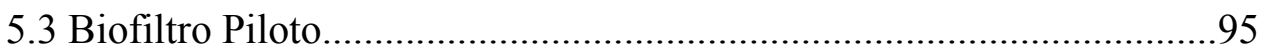

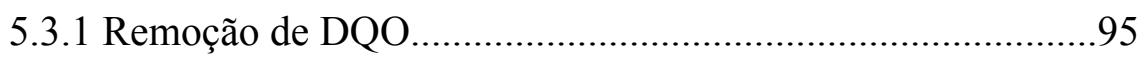

5.3.2 Remoção de Nitrogênio......................................................96

5.3.3 Remoção de sólidos..........................................................104

5.4 Enquadramento do efluente produzido ao padrão de lançamento estabelecido

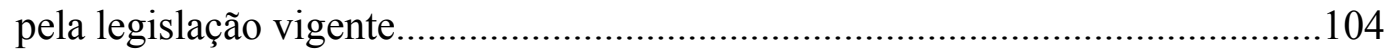

5.5 Exames microbiológicos...............................................................110

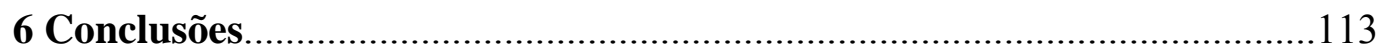

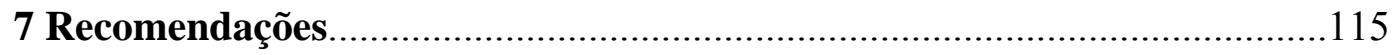

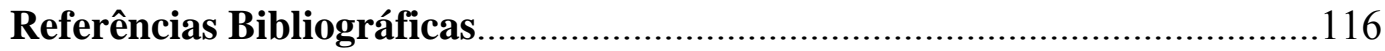




\section{Introdução}

O lançamento de efluentes em corpos receptores deve atender aos padrões da legislação ambiental vigente como, por exemplo, a resolução CONAMA 357 de 17 de março de 2005.

No Brasil, sistemas anaeróbios para tratamento de efluentes são comumente utilizados devido às diversas vantagens que apresentam, quando comparados aos sistemas aeróbios. Porém, esses sistemas quando utilizados para tratamento de esgoto sanitário produzem efluentes com concentrações de nitrogênio amoniacal $\left(\mathrm{N}^{-N_{3}}\right)$ acima do valor permitido pela legislação. Assim, o pós-tratamento desses efluentes é, na atualidade, uma necessidade para estações que empregam essas biotecnologias. Surgem, então, diversas propostas para pós-tratamento de efluentes anaeróbios GARBOSSA (2006), TAWFIK et al. (2005) e BODÍK et al. (2001).

O uso combinado dos processos aeróbio e anaeróbio apresenta grande potencial para tratamento e pós-tratamento de efluentes. A combinação desses processos possibilita a construção de modelos mais compactos (menor área de implantação da estação), com menor consumo de energia elétrica com aeradores (devido à menor demanda de OD) e menor produção de biomassa (lodo) (CAMPOS et al. 1999).

Segundo GARBOSSA (2003), os sistemas aeróbio/anóxico apresentam maior viabilidade técnica-econômica, quando comparados aos sistemas tradicionais, para serem utilizados como alternativas para remoção de nitrogênio amoniacal promovendo nitrificação e desnitrificação.

Para CHERNICHARO (2001) os biofiltros aeróbios submersos (BFs) são, na atualidade, uma atraente alternativa para pós-tratamento de efluentes anaeróbios. GONÇALVES et al. (1998) investigaram o desempenho de um BF utilizado no póstratamento de efluente de reator UASB. Esses autores concluíram ser promissora a associação UASB + BF para tratamento de esgoto sanitário no Brasil, constatando em sua pesquisa eficiência de remoção de $95 \%$ de SS e DBO5 e $88 \%$ de DQO, além de produção de lodo $30 \%$ menor que nas configurações européias.

As configurações atuais de BFs utilizadas como unidades de tratamento secundário ou terciário apresentam limitações quanto a conversão do nitrogênio amoniacal a $\mathrm{N}_{2}$. Para que tal conversão ocorra, é necessário alternância entre o ambiente aeróbio e anóxico para favorecer a nitrificação e desnitrificação, respectivamente. A 
oxidação da amônia, na maioria das propostas de BFs atuais, chega somente ao estágio da nitrificação.

A nitrificação pode garantir concentrações efluentes de nitrogênio amoniacal, em BFs, abaixo do valor fixado pelos padrões de lançamento da legislação ambiental. Porém, o lançamento de nitrito ou nitrato em copos d'água, pode resultar em sérios danos a saúde humana causando doenças como a metahemoglobinemia (síndrome do bebê azul) (CROLL \& HAYES, 1988).

Diante disso surgiram diversas propostas para promover nitrificação e desnitrificação em um único sistema de tratamento de água residuárias GUO et. al (2005), WALTER et. al (2005), CHUI et. al (1996).

Nesse contexto, uma nova configuração de biofiltro aerado submerso foi idealizada nessa pesquisa, para ser utilizada como unidade de pós-tratamento do efluente de reator UASB. Esse sistema, composto por um conjunto de três reatores concêntricos, foi capaz de promover nitrificação e desnitrifiação em um único sistema, além da remoção da matéria carbonácea recalcitrante presente no efluente do reator UASB. Compacidade, baixa produção de lodo e alto potencial para conversão total de nitrogênio amoniacal a $\mathrm{N}_{2}$, foram as principais vantagens oferecidas por tal configuração. Assim, esta tecnologia associada a sistemas anaeróbios, poderá ser excelente alternativa para tratamento de esgoto sanitário em grandes centros urbanos. 


\section{Revisão Bibliográfica}

2.1 Microbiologia para tratamento de esgoto sanitário.

É de extrema importância compreender os mecanismos envolvidos no metabolismo microbiano, para otimização de estações de tratamento de esgoto sanitário que utilizam biotecnologias. Os principais microrganismos envolvidos no tratamento de águas residuárias são: bactérias, fungos, protozoários e vermes. Dentre eles, as bactérias possuem grande representatividade na estabilização de compostos presentes no esgoto sanitário. (VON SPERLING, 1996).

As bactérias são basicamente compostas por $80 \%$ de água e $20 \%$ de material seco do qual $90 \%$ é matéria orgânica e $10 \%$ inorgânica. Os elementos químicos que as compõe são basicamente: Carbono (50\%), Oxigênio(20\%), Nitrogênio(14\%), Hidrogênio (8\%) e Fósforo (3\%). Para suas atividades metabólicas é de extrema importância a disponibilidade, nos meios em que elas se encontram, de fontes desses elementos. (METCALF \& EDDY, 1991).

O processo para obtenção de energia, realizado por bactérias para desempenharem suas atividades básicas como reprodução, locomoção e transporte de nutrientes é denominado anabolismo ou biossíntese.

Como os nutrientes, as fontes de energia também podem ser obtidas do meio ambiente; dois tipos de energia são utilizados: a luminosa e a química. Embora muitos organismos obtenham energia da luz (fotossíntese) a maior parte dos microrganismos o faz a partir da quebra de compostos químicos - quimiossíntese. Esse processo de quebra e liberação de energia é chamado catabolismo (MADIGAN et al.,1996)

Para o metabolismo bacteriano, são necessárias fontes de carbono, energia e nutrientes como: nitrogênio, fósforo, enxofre, magnésio e cálcio. São denominadas quimioautótrofas (exemplo: bactérias nitrificantes) por terem como fonte de carbono e energia, $\mathrm{CO}_{2}$ e matéria inorgânica, respectivamente, e quimioheterotróficas por utilizarem matéria orgânica como precursor para as duas fontes.

Quanto ao tipo de respiração que realizam, as bactérias podem ser classificadas como aeróbias, anóxicas e anaeróbias. Aeróbias quando o aceptor final na cadeia de elétrons é o oxigênio; anóxicas quando o aceptor final é nitrato $\mathrm{NO}_{3}^{-}$(processo 
denominado desnitrificação); e anaeróbias quando o aceptor é sulfato $\left(\mathrm{SO}_{4}{ }^{-2}\right)$ ou dióxido de carbono $\left(\mathrm{CO}_{2}\right)$ tendo como resultado final produção de sulfeto $\left(\mathrm{H}_{2} \mathrm{~S}\right)$ e metano $\left(\mathrm{CH}_{4}\right)$ respectivamente. Para geração de energia as principais reações que ocorrem em condições aeróbias, anóxicas e anaeróbias são (MADIGAN et al,1996 ):

- Condições aeróbias

$$
\mathrm{C}_{6} \mathrm{H}_{12} \mathrm{O}_{2}+6 \mathrm{O}_{2} \rightarrow 6 \mathrm{CO}_{2}+6 \mathrm{H}_{2} \mathrm{O} \quad \Delta \mathrm{G}^{o}=-686 \mathrm{kcal} / \mathrm{mol}(2.1)
$$

- Condições anóxicas: redução de nitratos (desnitrificação)

$$
2 \mathrm{NO}_{3}{ }^{-}+2 \mathrm{H}^{+} \rightarrow \mathrm{N}_{2}+2,5 \mathrm{O}_{2}+\mathrm{H}_{2} \mathrm{O} \quad \Delta \mathrm{G}^{o}=-1,6 \mathrm{kcal} / \mathrm{mol}(2.2)
$$

- Condições anaeróbias: redução de sulfatos (dessulfatação) $\mathrm{CH}_{3} \mathrm{COOH}+\mathrm{SO}_{4}{ }^{2-}+2 \mathrm{H}^{+} \rightarrow \mathrm{H}_{2} \mathrm{~S}+2 \mathrm{H}_{2} \mathrm{O}+2 \mathrm{CO}_{2} \quad \Delta \mathrm{G}^{\circ}=-38,0 \mathrm{kcal} / \mathrm{mol}(2.3)$

- Condições anaeróbias: redução de $\mathrm{CO}_{2}$ (metanogenese hidrogenotrófica)

$$
4 \mathrm{H}_{2}+\mathrm{CO}_{2} \rightarrow \mathrm{CH}_{4}+2 \mathrm{H}_{2} \mathrm{O} \quad \Delta \mathrm{G}^{o}=-26,5 \mathrm{kcal} / \mathrm{mol}(2.4)
$$

- Condições anaeróbias: metanogenese acetotrófica.

$$
\mathrm{CH}_{3} \mathrm{COOH} \rightarrow \mathrm{CH}_{4}+\mathrm{CO}_{2} \quad \Delta G^{\circ}=-16,2 \mathrm{kcal} / \mathrm{mol}(2.5)
$$

As bactérias aeróbias são as que se reproduzem mais rapidamente por utilizarem um agente oxidante que produz alta quantidade de energia, como é possível observar pelo valor de $\Delta G^{o}$ apresentado na equação 2.1. Daí a problemática dos processos aeróbios - seu rápido crescimento bacteriano - gerando altas quantidades de biomassa (lodo) nas estações de tratamento e resíduo sólido passível de tratamento. Esse problema não é tão grave nos demais tipos de respiração, pois o agente oxidante utilizado libera menos energia resultando num crescimento mais lento.

\subsection{Biofilme em reatores de crescimento aderido ou imobilizado}

Reatores de crescimento aderido são sistemas em que um material inerte é utilizado para aumento da área superficial, aderência e colonização de microrganismos responsáveis pelo tratamento de águas residuárias. Esses reatores apresentam como principal vantagem o aumento do tempo de retenção celular que resulta em modelos mais eficientes e compactos. Sistemas compactos são de grande interesse para áreas com pouco espaço para implantações de estações de tratamento, como grandes centros urbanos, por exemplo. 
Diversas propostas de biotecnologias de crescimento aderido têm sido propostas para tratamento e pós-tratamento de efluentes como apresentadas por DAVIDSON et.al (2008), MODIN et. al (2008) e RAMOS et. al.(2007).

O biofilme é o resultado da aderência de sucessivas colônias de microrganismos ao material suporte, que vão se sobrepondo umas às outras formando uma película - um filme. Nesse filme são estabelecidos gradientes de concentração dos substratos utilizados pelos microrganismos e trocas com o meio líquido de subprodutos metabolizados. O mecanismo de aderência se dá pela produção de polímeros extracelulares e é influenciado por interações célula-célula e pela composição do meio.

Segundo WIJFFELS e TRAMPER (1995) a formação do biofilme é um processo muito complexo. Sua formação é resultado da combinação de uma série de fatores tais como: crescimento bacteriano; consumo de substrato; mecanismos de aderência das bactérias; transferência de massa interna e externa de substrato e demais produtos do metabolismo celular; morte dos microrganismos; perda por tensão de cisalhamento sobre o biofilme; descolamento de biofilme; estrutura do material suporte; competição entre bactérias e efeitos de predadores.

As condições de operação como, concentração do substrato, $\mathrm{pH}$, temperatura, fator de diluição (recirculação) e turbulência, influenciam diretamente tais fatores apontados. A tabela 2.1 apresenta, qualitativamente, o efeito dessas condições sobre os fatores de formação do biofilme.

Tabela 2.1- Influência das condições de operação sobre os fatores de formação do biofilme em sistemas de crescimento aderido.

\begin{tabular}{cccc}
\hline & Temperatura & Turbulencia & Recirculação \\
\hline Transferência & + & + & $\mathbf{0}$ \\
massa & & & + \\
Aderência & $?$ & - & + \\
Tensão de & + & + & + \\
Cisalhamento & & + & $\mathbf{0}$ \\
Descolamento & + & + & + \\
Consumo de & + & & $\mathbf{0}$ \\
Substrato & & + & $\mathbf{0}$ \\
Densidade & $?$ & + & \\
Difusão & + &
\end{tabular}

(+) Aumento; (-) Diminuição; (0) Sem efeito; (?) Sem previsão.

Fonte: WIJFFELS e TRAMPER (1995). 
Pela tabela 2.1 é possível observar, por exemplo, que a turbulência influencia diretamente quase todos os fatores envolvidos com a formação do biofilme. $\mathrm{O}$ aumento da turbulência em sistemas de crescimento aderido pode acarretar na diminuição da espessura de fluido estagnado na interface fluido-biofilme, e conseqüente queda na resistência à transferência de massa para camadas mais interiores. Esse fato, portanto, resulta em aumento das taxas de crescimento bacteriano e de consumo de substrato nas camadas mais profundas do biofilme.

O aumento da turbulência também acarretará em aumento da tensão de cisalhamento aplicada sobre o biofilme. Consequentemente, a taxa de aderência de células e o tipo de células aderidas serão influenciados. Biofilmes formados sob altas tensões de cisalhamento são mais densos e menos sensíveis a aumentos de tais tensões. Coeficientes de difusão e concentração de biomassa também serão maiores em biofilmes mais densos (BRYERS, 1988 apud WIJFFELS e TRAMPER, 1995). A figura 2.1 mostra um esquema da seção transversal de um biofilme:

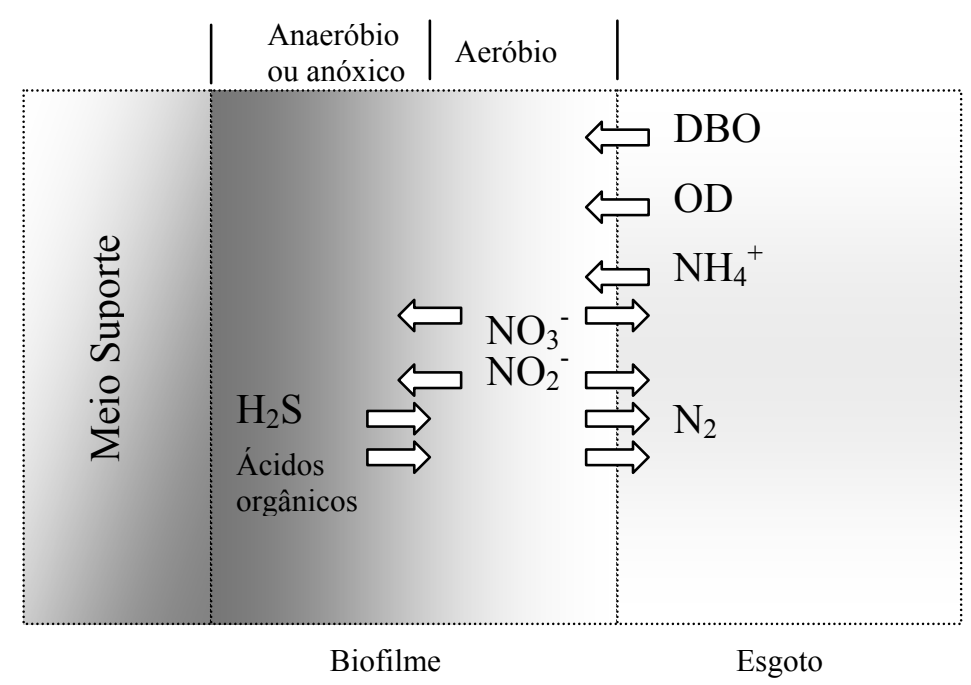

Figura 2.1- Esquema de um Biofilme

Fonte: (Adaptado de Von Sperling,1996)

Em um biofiltro aerado submerso, por exemplo, o biofilme pode aparecer estratificado (anaeróbio, anóxico e aeróbio) em virtude da baixa turbulência como apresentado na Figura 2.1. O aumento da espessura do biofilme pode dificultar a passagem de oxigênio dissolvido e demais substratos das camadas mais externas para as mais internas do meio suporte.

\footnotetext{
${ }^{1}$ BRYERS, J. D. (1998). Modeling biofilm accumulation. In: Physiological Models in Microbiology (Bazin, M. J. and Prosser, J. I., eds.). Vol. 2. CRC Press, Boca Raton, Florida, 109-144.
} 
$\mathrm{Na}$ região aeróbia do biofilme, o nitrogênio amoniacal $\left(\mathrm{N}-\mathrm{NH}_{3}\right)$ poderá ser convertido a nitrito $\left(\mathrm{N}-\mathrm{NO}_{2}{ }^{-}\right)$e, posteriormente, a nitrato $\left(\mathrm{N}-\mathrm{NO}_{3}{ }^{-}\right)$, que poderá ser reduzido na camada anóxica.

Sob condições anaeróbias poderá ocorrer produção de ácidos orgânicos e redução de sulfatos. Nas regiões mais internas de um biofilme espesso (zona anaeróbia/anóxica próxima ao meio suporte) o substrato pode não mais atender à demanda necessária para a sobrevivência dos microrganismos o que os leva à endogenia podendo causar o desprendimento de partes da biomassa.

A tensão de cisalhamento, oriunda do escoamento é, portanto, um importante fator regulador do crescimento do biofilme e, consequentemente, do seu potencial para consumo de um determinado substrato. Se esse crescimento não for controlado, ocorrerá acúmulo de lodo no leito do reator utilizado, causando aumento na perda de carga do sistema e queda da eficiência do tratamento.

\subsection{Remoção biológica do nitrogênio.}

A remoção de compostos nitrogenados de efluentes tem recebido atenção cada vez mais crescente, em virtude dos sérios problemas ambientais com os quais esses estão envolvidos. O nitrogênio, em suas diversas formas de oxidação, está relacionado com problemas de poluição em corpos receptores como a eutrofização, por exemplo, além de oferecer sérios riscos à saúde humana quando presente em águas de abastecimento. Portanto, muito cuidado deve ser tomado ao se considerar à remoção desses compostos, sem levar em conta seus estágios de oxidação.

Para remoção biológica do nitrogênio, dois processos devem ser considerados: a nitrificação e a desnitrificação. O primeiro ocorre em condições aeróbias, enquanto que o segundo sob condições anóxicas. Logo, o projeto de sistemas que visam à remoção completa de compostos nitrogenados, deve prever condições suficientes para que esses processos ocorram de forma seqüencial e/ou simultânea. A figura 2.2 apresenta um esquema das diferentes vias de conversão do nitrogênio. 

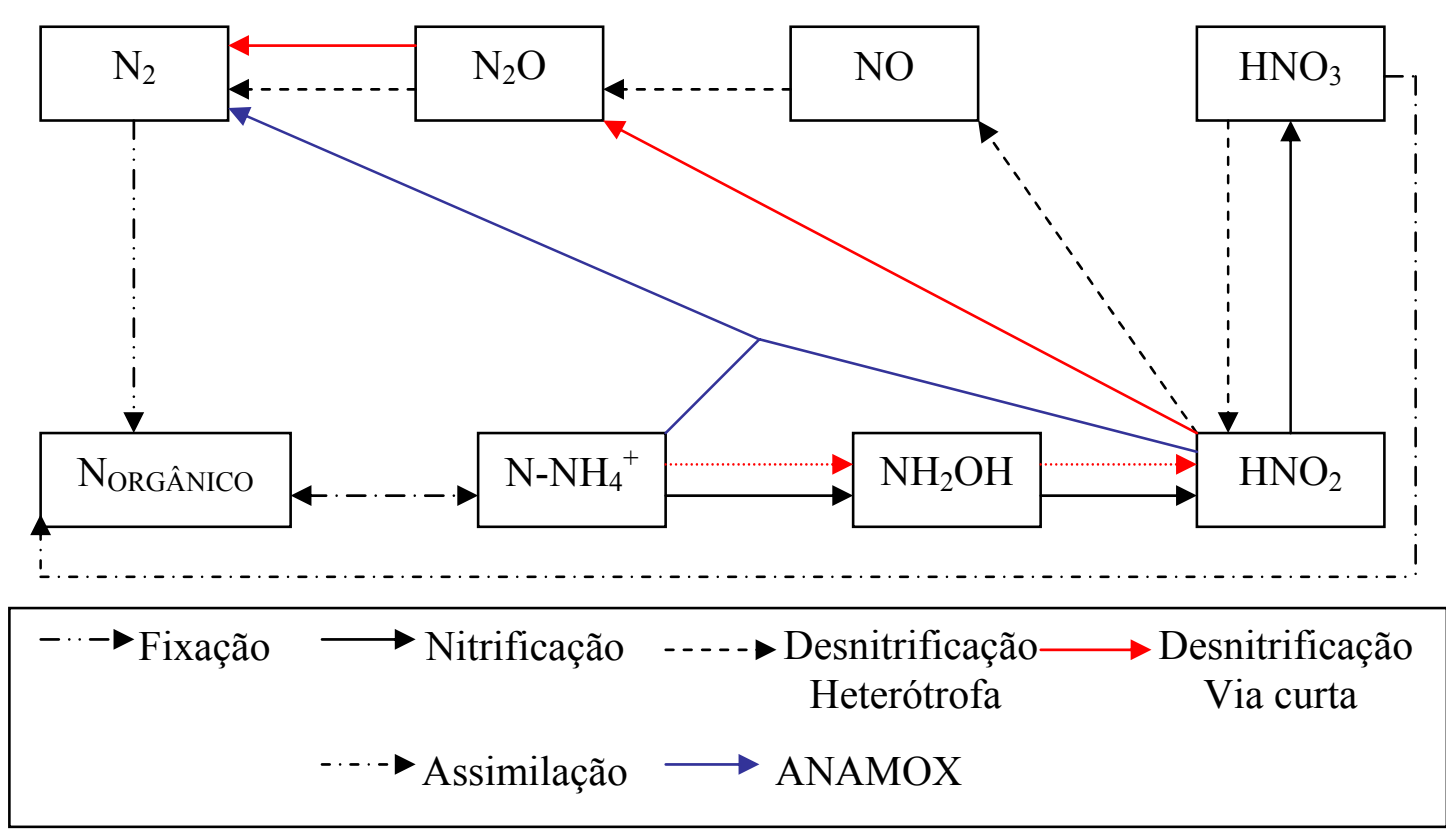

Figura 2.2 - Rotas de conversão do nitrogênio.

Fonte: Adaptado Van LOOSDRECHT e JETTEN (1998).

\subsubsection{Nitrificação.}

$\mathrm{O}$ processo de oxidação do nitrogênio amoniacal $\left(\mathrm{N}-\mathrm{NH}_{3}\right)$ a compostos mais oxidados é denominado nitrificação. Tal processo pode ocorrer basicamente em duas etapas. Na primeira, denominada nitritação, o nitrogênio amoniacal é oxidado a nitrito $\left(\mathrm{N}_{-} \mathrm{NO}_{2}{ }^{-}\right)$e na segunda, o nitrito pode ser oxidado a nitrato $\left(\mathrm{N}^{-\mathrm{NO}_{3}}{ }^{-}\right)$em uma etapa denominada nitratação. Sistemas projetados para promoverem nitrificação devem apresentar alguns fatores ambientais essenciais para crescimento das bactérias nitrificantes. Esses fatores são basicamente: baixa carga orgânica afluente, oxigênio dissolvido e alcalinidade em $\mathrm{CaCO}_{3}$ em quantidade e disponibilidade suficientes.

A nitrificação é um processo que ocorre à custa do consumo da alcalinidade e do oxigênio dissolvido presente no sistema, como é possível visualizar na equação 2.6 (HENZE et. al 1997).

$$
\mathrm{NH}_{4}{ }^{+}+1,83 \mathrm{O}_{2}+1,98 \mathrm{HCO}_{3}{ }^{-} \rightarrow 0,98 \mathrm{NO}_{3}^{-}+1,04 \mathrm{H}_{2} \mathrm{O}+0,021 \mathrm{C}_{5} \mathrm{H}_{7} \mathrm{NO}_{2}+1,88 \mathrm{H}_{2} \mathrm{CO}_{3} \text { (2.6) }
$$

Caso a alcalinidade fornecida ao sistema não seja suficiente para manter o $\mathrm{pH}$ dentro do valor ótimo (entre 7 e 8 ) para o metabolismo das bactérias nitrificantes, a 
nitrificação será inibida. Assim, sistemas construídos para promover nitrificação devem prever adição de alcalinizante.

As bactérias responsáveis pela nitrificação em estações de tratamento de efluentes são autótrofas e restritas a um pequeno número de gêneros: Nitrossomonas, Nitrosospira, Nitrosococcus e Nitrobacter. Esse fato, aliado a baixa velocidade de crescimento dessas bactérias, torna a nitrificação um processo muito susceptível a fatores inibidores. Segundo GRUNDITZ e DALHAMMAR (2000) uma carga tóxica afluente ao sistema, por exemplo, poderia interromper o processo de nitrificação por semanas. LAURSEN e JANSEN (1995) ${ }^{2}$ apud GRUNDITZ e DALHAMMAR (2000), em um estudo efetuado em 38 estações de tratamento de tratamento de efluentes da Dinamarca, apontaram problemas na nitrificação por fatores inibidores em um terço das mesmas.

A baixa velocidade de crescimento das bactérias nitrificantes também pode ser um fator desfavorável na competição, por espaço no biofilme, contra as bactérias heterótrofas que possuem maior taxa de crescimento, comprometendo a eficiência global do sistema na oxidação do $\mathrm{N}-\mathrm{NH}_{3}$. As bactérias heterótrofas são responsáveis pela redução da carga orgânica afluente em sistemas utilizados para tratamento de esgoto sanitário. Assim, tal carga pode ser um fator inibidor para nitrificação nesses sistemas. Segundo POLANCO et. al (2000), essa carga orgânica afluente pode comprometer seriamente a nitrificação em biofiltros aerados submersos empregados no tratamento de efluentes urbanos.

Para CARRERA et. al (2004), a competição entre bactérias autótrofas e heterótrofas é influenciada diretamente pela relação $\mathrm{DQO} / \mathrm{N}$ sendo esse, um dos parâmetros mais críticos no processo da nitrificação.

POLANCO et. al (2000), investigaram a influência dessa relação na competição entre bactérias autótrofas e heterótrofas em um biofiltro aerado submerso utilizado no tratamento de efluente industrial. Para relação DQO/N superior a 4, ( $200 \mathrm{mg}$ de DQO/L e $50 \mathrm{mg}$ de $\mathrm{N}^{-\mathrm{NH}_{4}}{ }^{+}$) a nitrificação foi inibida em virtude da competição, por espaço no biofilme, entre as bactérias autótrofas e heterótrofas . A tabela 2.1 apresenta valores da relação $\mathrm{DQO} / \mathrm{N}$, acima dos quais ocorre inibição da nitrificação, encontrados por diversos autores.

\footnotetext{
${ }^{2}$ LAURSEN, K. D. e JANSEN, J. la C. (1995) Are 50\% af danske renseanloeg hoemmede?) Stads - og havneingen-iØren 2, 41-43 (in Danish).
} 
Tabela 2.1 - Valores de DQO/N limitantes para nitrificação.

\begin{tabular}{|c|c|c|c|}
\hline $\begin{array}{l}\text { Tipo de } \\
\text { Efluente }\end{array}$ & $\begin{array}{c}\text { Biotecnologia } \\
\text { utilizada }\end{array}$ & $\mathrm{DQO} / \mathrm{N}$ & Referência \\
\hline Industrial & Lodo Ativado & 3,4 & CARRERA et. al (2004) \\
\hline $\begin{array}{l}\text { Esgoto } \\
\text { sintético }\end{array}$ & $\mathrm{BF}$ & 4 & POLANCO et. al (2000) \\
\hline $\begin{array}{l}\text { Esgoto } \\
\text { sintético }\end{array}$ & $\begin{array}{l}\text { Reator aeróbio } \\
\text { de Membrana }\end{array}$ & 2,8 & WALTER et. al (2005) \\
\hline $\begin{array}{l}\text { Esgoto } \\
\text { sintético }\end{array}$ & $\begin{array}{l}\text { Reator aeróbio } \\
\text { de Membrana }\end{array}$ & 5,3 & MATSUMOTO et. al (2007) \\
\hline $\begin{array}{l}\text { Esgoto } \\
\text { sintético }\end{array}$ & $\begin{array}{l}\text { Biofiltro } \\
\text { aerado }\end{array}$ & 3 & LING e CHEN (2005) \\
\hline
\end{tabular}

Pelos dados apresentados na tabela 2.1 é possível concluir que o valor da relação DQO/N deve ser de aproximadamente 3,7 para que não ocorra inibição da nitrificação. Porém, esse valor pode variar bastante dependendo da fonte de carbono empregada e do tipo de sistema utilizado para tratamento do efluente considerado. OKABE et. al (1996), por exemplo, observou queda na taxa de nitrificação em seu sistema para valores de DQO/N maiores que 1,5. GRABINSKA-LONIEWSKA et. al $(1985)^{3}$ apud DINÇER e KARGI (2000) relatam como relação DQO/N ideal para nitrificação o valor igual a 1,1, utilizando glicerol como fonte de carbono.

Outros parâmetros como: $\mathrm{pH}$, temperatura, alcalinidade, carga de nitrogênio afluente ao sistema, e oxigênio dissolvido (OD) também podem ser limitantes à nitrificação. A tabela 2.2 apresenta valores para os parâmetros $\mathrm{pH}$, temperatura e OD, reportados na literatura, abaixo dos quais, ocorre inibição da nitrificação.

Tabela 2.2 - Valores de $\mathrm{pH}$, temperatura e $\mathrm{OD}$, limitantes para nitrificação.

\begin{tabular}{cccc}
\hline Temperatura ${ }^{\circ} \mathrm{C}$ & $\begin{array}{c}\text { OD } \\
(\mathrm{mg} / \mathrm{L})\end{array}$ & $\mathrm{pH}$ & Referência \\
\hline 25 & 2,0 & $7,5 \pm 0,5$ & CARRERA et. al (2005) \\
20 & $>1,0$ & 8,2 & VILLAVERDE et. al (1997) \\
16 & 4,0 & 7,5 & ROSTRON et. al $(2001)$ \\
15 & 2,5 & 7,2 & ARAVINTHAN et. al $(2001)$ \\
\hline
\end{tabular}

${ }^{3}$ GRABINSKA-LONIEWSKA, A.; SLOMEZYNSKA, T.; KANSKA, Z. (1985). Denitrification studies with glycerol as a carbon source. Wat Res 1985; n.19, p. 1471-7. 


\subsubsection{Desnitrificação.}

As biotecnologias utilizadas para remoção de nitrogênio amoniacal devem prever sua completa oxidação até a forma de nitrogênio gasoso $\left(\mathrm{N}_{2}\right)$. Muitas propostas atuais visam somente redução de nitrogênio amoniacal a nitrato $\left(\mathrm{N}^{-\mathrm{NO}_{3}}{ }^{-}\right)$. Porém, a presença de nitratos em corpos receptores está associada a doenças em seres humanos como a metahemoglobinemia, também conhecida como síndrome do "bebê azul" (CROLL \& HAYES, 1988). Logo, a remoção de nitratos de efluentes torna-se uma necessidade imperativa.

A remoção biológica do nitrato de águas residuárias é denominada desnitrificação. É um processo efetuado por bactérias heterótrofas pertencentes a vários gêneros como: Pseudomonas, Achromobacter, Alcaligenes, Bacillus, Micrococcus, Proteus, Hiphomicrobium, Chromobacterium, Halobacterium, Moraxella, Neisseria, Paracoccus, Azospirillum, Rhodopseudomonas, Vibrio, Xanthomonas e Klebsiella (RITTMAN e LANGELAND, $1985^{4}$ apud SOUSA e FORESTI, 1999). Esse processo também pode realizado por bactérias autótrofas como, por exemplo, a Thiobacillus denitrificans ( KOENIG e LIU, 2001) que utilizam compostos reduzidos de enxofre como doador de elétrons.

Segundo TIEDJE (1988) apud BARBER e STUCKEY (2000), existem três tipos de redução biológica do nitrato:

a) A desnitrificação ( que pode ser heterotrófica e/ou autotrófica) (eqs. 2.7 e 2.8 )

b) Assimilação biológica do nitrato (eq. 2.9)

c) Redução dissimilativa do nitrato para íon amônio. (eq. 2.10)

REYES-AVILA et. al (2004) apresentam as reações estequiométricas entre acetato e nitrato ( $\mathrm{DQO} / \mathrm{N}=1,07)$, considerando desnitrificação heterotrófica, e entre sulfato e nitrato $(\mathrm{S} / \mathrm{N}=1,43)$, considerando desnitrificação autotrófica, como mostrado nas equações 2.7 e 2,8 , respectivamente.

$$
\begin{gathered}
1,25 \mathrm{CH}_{3} \mathrm{COOH}+2 \mathrm{NO}_{3}^{-} \rightarrow 2,5 \mathrm{CO}_{2}+\mathrm{N}_{2}+1,5 \mathrm{H}_{2} \mathrm{O}+2 \mathrm{OH}^{-}, \Delta \mathrm{G}^{\mathrm{o}}=-1054,8 \mathrm{~kJ} / \text { reação (2.7) } \\
1,25 \mathrm{~S}^{2-}+2 \mathrm{NO}_{3}{ }^{-}+2 \mathrm{H}^{+} \rightarrow 1,25 \mathrm{SO}_{4}{ }^{2-}+\mathrm{N}_{2}+\mathrm{H}_{2} \mathrm{O}, \Delta \mathrm{G}^{\mathrm{o}}=-972,8 \mathrm{~kJ} / \text { reação (2.8) }
\end{gathered}
$$

\footnotetext{
${ }^{4}$ RITTMANN, B.E. e LANGELAND, W.E. (1985). Simultaneous denitrification with nitrification in single channel oxidation ditches. Journal Water Pollution Control, v.45, n.2, p.249 - 260.
} 
TIEDJE (1988) apud BARBER e STUCKEY (2000), apresenta as reações estequiométricas da redução assimilatória e dissimilatória do nitrato, nas equações 2.9 e 2.10 , respectivamente.

$$
\begin{gathered}
5\left(\mathrm{C}_{\text {orgânico }}\right)+2 \mathrm{H}_{2} \mathrm{O}+4 \mathrm{NO}_{3}{ }^{-} \rightarrow 2 \mathrm{~N}_{2}+4 \mathrm{OH}^{-}+5 \mathrm{CO}_{2}, \Delta \mathrm{G}^{\mathrm{o}}=-560 \mathrm{~kJ} / \mathrm{mol} \mathrm{N} \\
\mathrm{NO}_{3}{ }^{-}+2 \mathrm{H}^{+}+4 \mathrm{H}_{2} \rightarrow \mathrm{NH}_{4}^{+}+3 \mathrm{H}_{2} \mathrm{O}, \Delta \mathrm{G}^{\mathrm{o}}=-600 \mathrm{~kJ} / \mathrm{mol} \mathrm{N}
\end{gathered}
$$

A desnitrificação heterotrófica é um processo que o ocorre obrigatoriamente sob condições anóxicas. As bactérias heterótrofas necessitam de fonte de carbono como doador de elétrons ao aceptor final da cadeia respiratória, no caso, o nitrato $\left(\mathrm{N}_{-} \mathrm{NO}_{3}{ }^{-}\right)$. Tal fonte de carbono pode ser matéria orgânica, compostos reduzidos de enxofre ou hidrogênio molecular.

A redução biológica do nitrato passa essencialmente por quatro etapas até o $\mathrm{N}_{2}$ como descrito por AUN (2007):

$$
\begin{gathered}
\text { Nitrato }\left(\mathrm{NO}_{3}{ }^{-}\right) \rightarrow \text { Nitrito }^{1}\left(\mathrm{NO}_{2}^{-}\right) \rightarrow \text { Óxido Nítrico } \\
\end{gathered}
$$

Sendo e-, o elétron fornecido pelo doador específico (matéria orgânica, por exemplo), cada etapa pode ser descrita pelas equações $2.12-2.15$, respectivamente.

$$
\begin{aligned}
& 4 \mathrm{e}^{-}+2 \mathrm{NO}_{3}^{-}+4 \mathrm{H}^{+} \rightarrow 2 \mathrm{NO}_{2}^{-}+2 \mathrm{H}_{2} \mathrm{O} \\
& 2 \mathrm{e}^{-}+2 \mathrm{NO}_{2}^{-}+4 \mathrm{H}^{+} \rightarrow 2 \mathrm{NO}+2 \mathrm{H}_{2} \mathrm{O} \\
& 2 \mathrm{e}^{-}+2 \mathrm{NO}+2 \mathrm{H}^{+} \rightarrow \mathrm{N}_{2} \mathrm{O}+\mathrm{H}_{2} \mathrm{O} \\
& 2 \mathrm{e}^{-}+\mathrm{N}_{2} \mathrm{O}+2 \mathrm{H}^{+} \rightarrow \mathrm{N}_{2}+\mathrm{H}_{2} \mathrm{O}
\end{aligned}
$$

A desnitrificação heterotrófica também pode ocorrer através de uma via metabólica na qual a o nitrito é reduzido diretamente a $\mathrm{N}_{2}$ em condições anóxicas. Esse processo, denominado desnitrificação via curta ou desnitrificação via acúmulo de 
nitrito, vem sendo investigado por outros pesquisadores como: WU et. al (2007), RUIZ et. al (2006) e YOO et. al (1999). A desnitrificação via curta oferece as seguintes vantagens, em relação a sistemas convencionais, segundo TURK e MAVINIC (1989) ${ }^{5}$ apud VILLAVERDE et. al (2000): (1) redução de 25\% da quantidade de oxigênio necessária para nitrificação, (2) $40 \%$ de redução de fonte de carbono para desnitrificação, (3) 30 a 40\% de redução no volume dos reatores utilizados e (4) alta taxa de desnitrificação e menor produção de lodo.

A desnitrificação via curta consiste na aplicação de condições adversas às bactérias desnitrificantes para que ocorra inibição da nitratação, ou seja, acúmulo de nitrito no sistema de tratamento utilizado. Tais condições são impostas por parâmetros operacionais do sistema como: $\mathrm{pH}$, temperatura, oxigênio dissolvido, concentração de nitrogênio amoniacal $\left(\mathrm{N}-\mathrm{NH}_{3}\right)$, concentração do próprio nitrito. Para RUIZ et. al (2006) o parâmetro que mais interfere no acúmulo de nitrito é a concentração de oxigênio dissolvido (OD). No sistema investigado por esses autores tal acúmulo ocorreu para valores de OD menores que $1 \mathrm{mg} / \mathrm{L}$. Já para VILLAVERDE et. al (2000), o principal causador de acúmulo de nitrito é a concentração afluente de $\mathrm{N}-\mathrm{NH}_{3}$.

$\mathrm{O}$ nitrogênio amoniacal na forma de íon amônio $\left(\mathrm{NH}_{4}{ }^{+}\right)$também pode ser convertido a nitrogênio gasoso $\left(\mathrm{N}_{2}\right)$, em meio anóxico, através de um processo denominado ANAMMOX ${ }^{\circledR}$ (Anaerobic ammonium oxidation) (MULDER et. al, 1995). Nesse processo, que ocorre em nível de biofilme através de um mecanismo ainda não muito bem conhecido, o íon amônio é utilizado como doador de elétrons ao aceptor final de elétrons na cadeia respiratória, que pode ser nitrito e/ou nitrato.

MULDER et. al, (1995) apresentam a reação estequiométrica para redução do íon amônio, como mostrado na equação 2.16 .

$$
5 \mathrm{NH}_{4}^{+}+3 \mathrm{NO}_{3}^{-} \rightarrow 4 \mathrm{~N}_{2}+9 \mathrm{H}_{2} \mathrm{O}+\mathrm{H}^{+}
$$

As principais vantagens desse processo, sobre os processos convencionais utilizados para remoção de nitrogênio, apontadas por SIEGRIST et. al (1998) são: alto potencial para tratamento de efluentes com altas concentrações de nitrogênio amoniacal,

\footnotetext{
${ }^{5}$ TURK, O. e MAVINIC, D. S. (1989). Maintaining nitrite build-up in a system acclimated to free ammonia. Water Research, Vol. 23, n. 11, p. 1383-1388.
} 
redução do consumo de oxigênio dissolvido e ausência da necessidade de adição externa de fontes de carbono.

A desnitrificação pode ocorrer simultaneamente ao processo de nitrificação, também em nível de biofilme, em um processo denominado SND (simultaneous nitrification/denitrification) relatado por diversos autores como: LI et. al (2008), QI et. al (2007), WEISSENBACHER et. al (2007), THIRD et. al (2005).

A proposta desse processo consiste em estabelecer, em um único reator, condições para que a nitrificação e desnitrificação ocorram simultaneamente através das camadas estratificadas do biofilme, como é possível observar na figura 2.3.

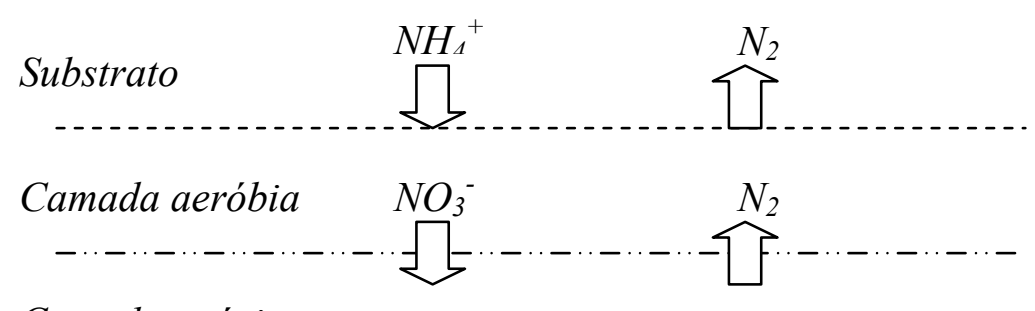

\section{Camada anóxica}

\section{Material suporte}

Figura 2.3 - Esquema da estratificação das camadas do biofilme no processo SND.

Alguns autores como GUO et. al ( 2005) e SEN e DENTEL (1998), propuseram sistemas com estratificação de camadas anóxicas e aeróbias ao longo de seus reatores favorecendo a ocorrência do processo SND.

A eficiência do processo SND depende essencialmente de três fatores: fonte de carbono para desnitrificação em quantidade e biodisponibilidade suficientes, concentração do oxigênio dissolvido no substrato (menor que $2,0 \mathrm{mg} / \mathrm{L}$ ), espessura das camadas (camadas mais espessas favorecem o processo SND) (POCHANA e KELLER, $1999{ }^{6}$ apud THIRD et. al, 2005).

Para que o processo SND seja completo é necessário que a taxa de oxidação do nitrogênio amoniacal seja aproximadamente igual à taxa de desnitrificação. Isso pode promover crescimento equilibrado entre as bactérias autótrofas e heterótrofas,

${ }^{6}$ POCHANA, K. e KELLER, J. (1999) Study of factors affecting simultaneous nitrification and denitrification (SND) Water Science and Technology, Vol. 39, n. 6, p. 61-68. 
respectivamente, sem danos de uma ou de outra população na competição por espaço no biofilme. Como o crescimento das bactérias autótrofas é mais lento que das heterótrofas, o carbono orgânico disponível no sistema deve ser de lenta degradação. Assim, a taxa de crescimento das bactérias heterótrofas é reduzida, não prejudicando o crescimento das autótrofas e garantindo completa remoção de nitrogênio via SND (THIRD et. al, 2005).

2.4 Sistemas utilizados para tratamento e/ou pós-tratamento de efluentes visando remoção de nitrogênio amoniacal.

Existem diversas propostas para tratamento de efluentes visando conversão de nitrogênio amoniacal a nitrogênio gasoso. Considerando os mecanismos convencionais de remoção de nitrogênio amoniacal de águas residuárias, as configurações de reatores utilizados para tal fim devem possuir basicamente, ambientes aeróbios e/ou anóxicos. METCALF e EDDY (2003), por exemplo, apresentam três tipos de configurações de lodos ativados utilizados para remoção de matéria orgânica e nitrogênio amoniacal de efluentes. São elas: sistema pós-anóxico, sistema pré-anóxico e sistema Bardenpho, como mostrado nas figuras $2.4,2.5$ e 2.6 , respectivamente.

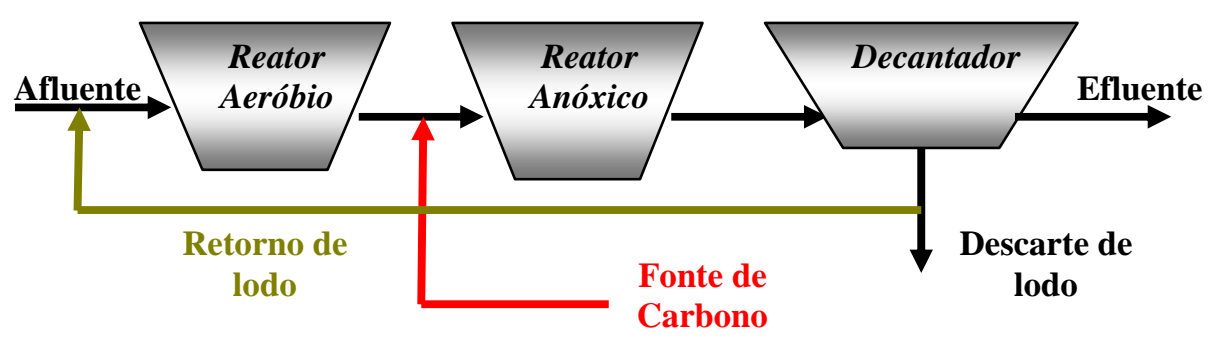

Figura 2.4 - Sistema pós-anóxico de lodos ativados para remoção de $\mathrm{N}-\mathrm{NH}_{3}$. Fonte: Adaptado (METCALF e EDDY, 2003).

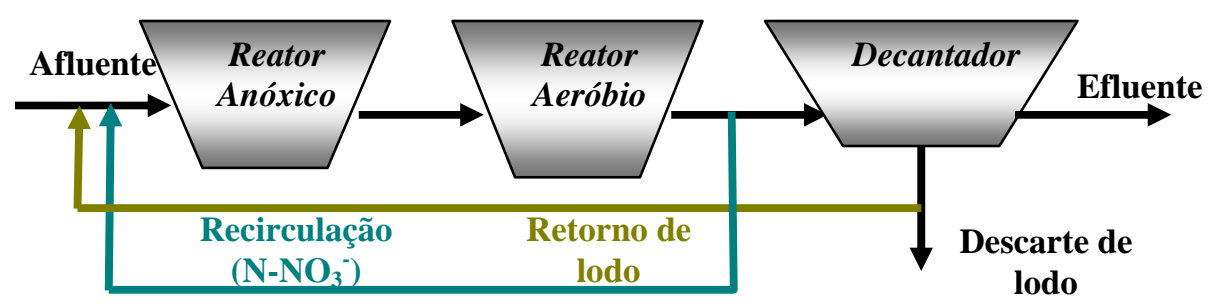

Figura 2.5 - Sistema pré-anóxico de lodos ativados para remoção de $\mathrm{N}-\mathrm{NH}_{3}$. Fonte: Adaptado (METCALF e EDDY, 2003). 


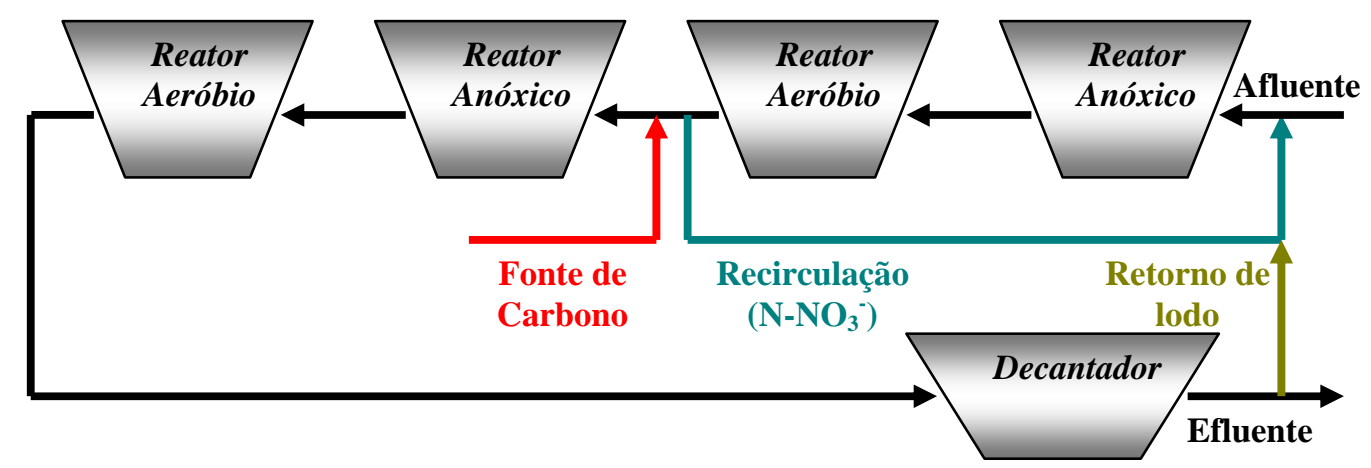

Figura 2.6 - Sistema tipo Bardenpho de lodos ativados para remoção de $\mathrm{N}_{-} \mathrm{NH}_{3}$. Fonte: Adaptado (METCALF e EDDY, 2003).

No sistema pós-anóxico o nitrogênio amoniacal é convertido a nitrato no reator aeróbio e a desnitrificação ocorre no reator anóxico. Como esse tipo de sistema é recomendado para tratamento é águas residuárias com baixa relação DQO/N, para que não ocorra inibição na nitrificação no sistema aeróbio, é necessário adição de fonte externa de carbono no sistema anóxico para servir como doador de elétrons às bactérias desnitrificantes.

No sistema pré-anóxico, recomendado para águas residuárias com alta relação DQO/N, o efluente nitrificado no sistema aeróbio é recirculado para o reator anóxico no qual ocorrerá a desnitrificação. A vantagem desse sistema pode estar na economia com adição de fonte externa de carbono no sistema anóxico, desde que o esgoto afluente ao sistema possua tal fonte às bactérias desnitrificantes em quantidade e qualidade suficientes para seu metabolismo. Outra vantagem desse sistema está no fato da carga orgânica ser reduzida no sistema anóxico. Isso garante que o crescimento das bactérias nitrificantes do sistema aeróbio não será inibido em virtude de sobrecargas orgânicas afluentes ao sistema.

O sistema tipo Bardenpho é resultado da combinação dos sistemas, pré e pósanóxicos, respectivamente, seguido de reator aeróbio para remoção da carga orgânica remanescente do sistema anóxico. A vantagem desse sistema está na resistência à eventuais sobrecargas de nitrogênio amoniacal produzindo efluente com reduzida concentração de $\mathrm{N}_{-} \mathrm{NH}_{3}$ e $\mathrm{N}-\mathrm{NO}_{3}{ }^{-}$. A desvantagem está no tamanho da área necessária para sua implantação sendo bem maior que os demais sistemas. 
$\mathrm{O}$ valor da relação $\mathrm{DQO} / \mathrm{N}$ para que ocorra desnitrificação completa pode variar entre 3,5 e 15 (HENCE, $1991^{7}$ apud QIN e LIU, 2006). Essa dispersão de valores é influenciada pelo tipo de fonte de carbono utilizada e pelo sistema de tratamento empregado.

As demais biotecnologias tais como: biofiltros aerados submersos, filtros percoladores, sistemas de leito fluidificado etc., devem apresentar configurações não muito diferentes da apresentada para sistemas de lodos ativados.

2.5 Biofiltros aerados submersos utilizados para tratamento de águas residuárias.

Existem diversas propostas para tratamento de efluentes utilizando biofiltros aerados submersos como: ÇEÇEN (1996), SÈGURET e RACAULT (1998), MANN et. al (1999), WESTERMAN et. al (2000), GUO et. al (2004).

GÁLVEZ et. al (2003), por exemplo, propuseram um biofiltro aeróbio submerso constituído por dois tubos de $6 \mathrm{~cm}$ de diâmetro por 2 metros de altura, interligados pela base por uma válvula e utilizando argila expandida como material suporte, como mostrado na figura 2.7 .

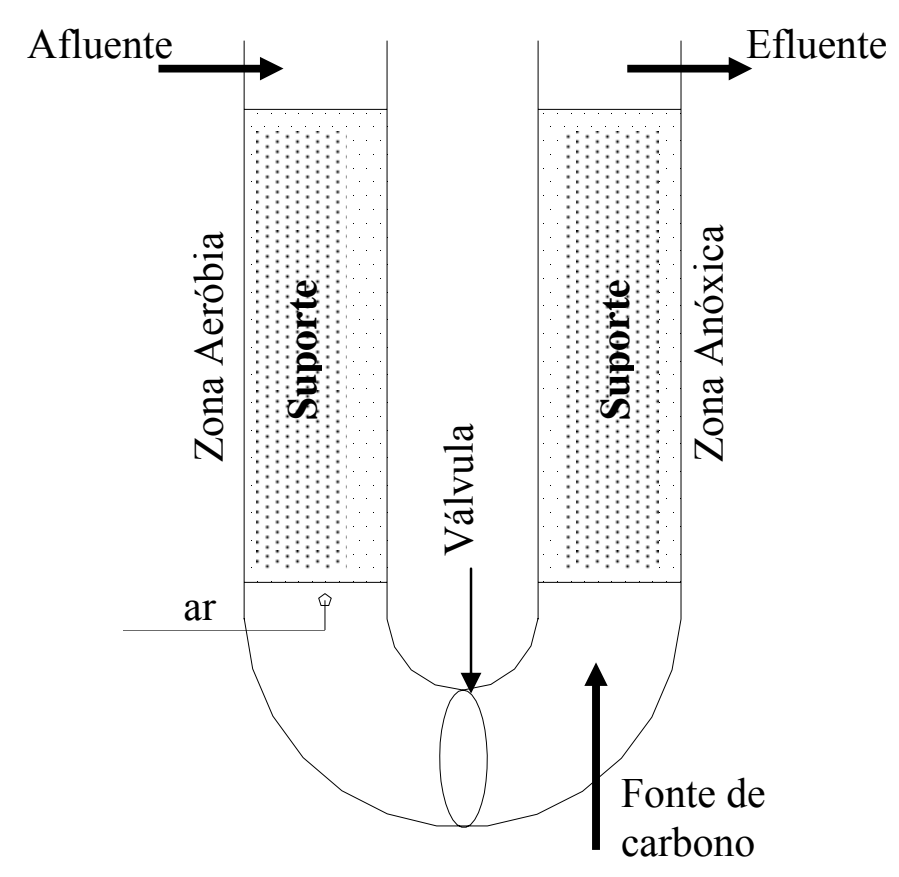

Figura 2.7- Esquema de um biofiltro aerado submerso.

Fonte: Adaptado (GÁLVEZ et. al, 2003)

\footnotetext{
${ }^{7}$ HENZE, M. (1991). Capabilites of biological nitrogen removal processes from wastewater. Water Sci. Technol. N. 23, p. 669-679.
} 
No esquema apresentado na figura 2.7, o esgoto afluente ao sistema entrava na parte superior da zona aeróbia e seguia, em fluxo descendente, até a base da zona anóxica. Daí, em fluxo ascendente, o efluente seguia para a saída do sistema, localizada no topo da zona anóxica. O objetivo principal da pesquisa era investigar a influência da carga hidráulica e da vazão de ar sobre o desempenho do sistema na remoção de nitrogênio. A oxidação do nitrogênio amoniacal a nitrato foi total (100\%) para carga hidráulica igual a $0,354 \mathrm{~m}^{3} / \mathrm{m}^{2} \mathrm{~h}(\mathrm{TDH}=1,6 \mathrm{~h})$ e vazão de ar igual a $7,8 \mathrm{~m}^{3} / \mathrm{m}^{2} \mathrm{~h}$. A fonte de carbono de carbono utilizada foi metanol, na razão DQO/N igual a 2,37, para eficiência de desnitrificação igual a 95\%.

CANZIANI et. al. (1999) investigaram o desempenho da combinação de biofiltros aeróbios submersos utilizados para conversão de nitrogênio amoniacal de esgoto sanitário. Esse sistema era formado por dois BFs ligados em série e intermediados por um sedimentador que removia sólidos suspensos produzidos pelo primeiro biofiltro. $\mathrm{O}$ primeiro $\mathrm{BF}$ era utilizado para remoção da fração orgânica carbonácea do esgoto afluente ao sistema, enquanto que o segundo, após o sedimentador, para nitrificação. A taxa média de nitrificação à temperatura de $20^{\circ} \mathrm{C}$ foi $0,84 \mathrm{~g} \mathrm{NH}_{4}{ }^{+}-\mathrm{N} \mathrm{m}^{-2-}$. Como material suporte foram utilizadas esferas de PVC com áreas superficiais de 140 a $230 \mathrm{~m}^{-1}$ para o primeiro biofiltro e de 230 a $400 \mathrm{~m}^{-1}$ para o segundo. Essa combinação de biofiltros não necessitava lavagens periódicas do leito, resultando em configuração com maior facilidade operacional.

GONÇALVES, et. al.(1998) analisaram o desempenho de um BF associado ao reator anaeróbio do tipo UASB, usado para tratamento secundário de esgoto sanitário. $\mathrm{O}$ BF foi construído em acrílico, com $100 \mathrm{~mm}$ de diâmetro, altura de $0,8 \mathrm{~m}$, volume de $6,3 \mathrm{~L}$ com meio suporte constituído por esferas de poliestireno com $3 \mathrm{~mm}$ de diâmetro com superfície específica de $1200 \mathrm{~m}^{2} / \mathrm{m}^{3}$. Nesse sistema lavagens periódicas do leito do BF eram efetuadas para retirada do excesso de lodo acumulado. Esses autores, apesar de não verificarem significativa remoção de nitrogênio amoniacal, constataram eficiência de remoção no efluente final, de $95 \%$ de $\mathrm{SS}_{\text {e }} \mathrm{DBO}_{5}$ e $88 \%$ de DQO com produção de lodo 30\% menor que nas configurações européias; concluíram ser promissora a associação UASB + BF para tratamento de esgoto sanitário no Brasil. A figura 2.8 ilustra o esquema experimental utilizado. 


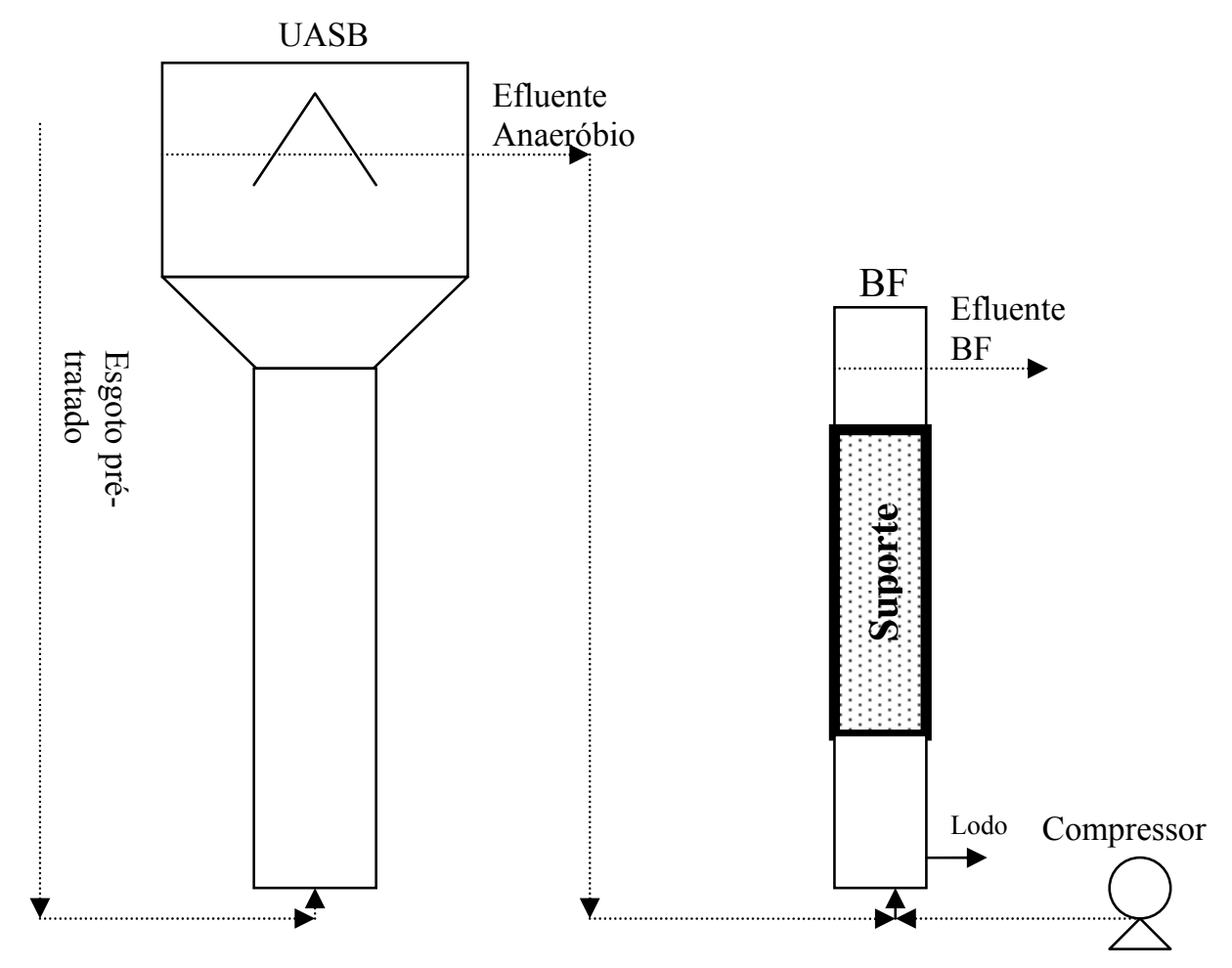

Figura 2.8- Esquema da associação UASB + BF. [Fonte: Adaptado GONÇALVES (1998)]

$\mathrm{O} \mathrm{BF}$, se associado a sistemas anaeróbios para pós-tratamento, pode promover nitrificação, na fase aeróbia, e desnitrificação, na fase anóxica. A fase aeróbia pode ser favorecida pelo fato da baixa carga orgânica oriunda de um sistema anaeróbio poder ser suficiente para garantir a predominância de microrganismos autótrofos nitrificantes no biofilme, sem interferências do crescimento das bactérias heterótrofas. A recirculação efetuada entre o BF e o sistema anaeróbio pode promover desnitrificação sem adição de fonte de externa de carbono, caso o afluente a contenha em quantidade e qualidade suficientes para as bactérias desnitrificantes. Nesse caso o sistema funcionaria com configuração para remoção de nitrogênio do tipo pré-anóxico como mostrado na figura 2.5 .

ARAÚJO JR. (2006) apresentou em sua pesquisa a configuração de um sistema compacto de biofiltro aerado submerso utilizado para tratamento de efluente industrial com concentração de nitrogênio amoniacal em média igual $160 \mathrm{mg} / \mathrm{L}$. Esse sistema, constituído por dois biofiltros operados em série sendo um anóxico e outro aeróbio, está esquematizado na figura 2.9. 


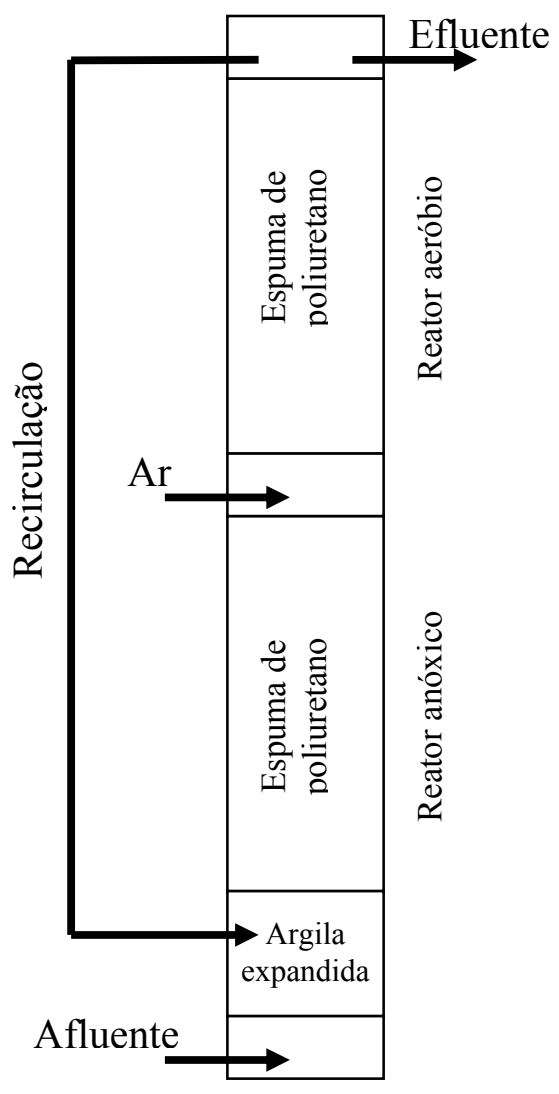

Figura 2.9 - Esquema do biofiltro utilizado por ARAÚJO JR. (2006).

Fonte: Adaptado (ARAÚJO JR., 2006).

No biofiltro apresentado na figura 2.9, funcionava como um sistema de remoção de nitrogênio tipo pré-anóxico (figura 2.5). A melhor condição operacional encontrada pelo autor foi alcançada utilizando TDH 35 h $(21$ h no reator anóxico, 14 h na zona aeróbia) e razão de recirculação $\left(R_{c}\right)$ igual 3,5. As eficiências de remoção de DQO, NTK e NT foram iguais a 97\%, 94\% e 77\%, respectivamente, com concentrações efluentes médias de $36 \pm 10 \mathrm{mg}$ de DQO/L, $2 \pm 1 \mathrm{mg}$ de $\mathrm{N}-\mathrm{NH}_{4}^{+} / \mathrm{L}$, de $8 \pm 3 \mathrm{mg}$ de N$\operatorname{org} / \mathrm{L}, 1 \pm 1 \mathrm{mg}$ de $\mathrm{N}-\mathrm{NO}_{2}{ }^{-} / \mathrm{L}, 26 \pm 23 \mathrm{mg}$ de $\mathrm{N}-\mathrm{NO}_{2}{ }^{-} / \mathrm{L}$.

A razão de recirculação, entre os reatores anóxico e aeróbio, em sistema de remoção de nitrogênio do tipo pré-anóxico é um fator importante para o desempenho desses na desnitrificação. ARAÚJO JR. (2006) investigou a influencia dessa razão sobre a desnitrificação para valores iguais a $0,5,1$ e 3,5, respectivamente. A eficiência do sistema na desnitrificação foi máxima para $\mathrm{R}_{\mathrm{c}}$ igual 3,5. LACALLE et al. $(2001)^{8}$ apud

\footnotetext{
8 LACALlE, M. L.;VILlAVERDE, S.; FDZ-POLANCO, F.; GRACÍA-ENCINA, P. A. (2001). Combined anaerobic/aerobic (UASB+UBAF) system for organic matter and nitrogen removal from a high strength industrial wastewater. Water Science and Technology, 44 (4): 255-262.
} 
ARAÚJO JR. (2006), operando um biofiltro aerado submerso em série com um sistema anaeróbio, alcançou eficiência máxima de desnitrificação para $\mathrm{R}_{\mathrm{c}}$ igual 6,7.

POLANCO (2000) verificou altas taxas de nitrificação, em BF com 2,5 m de altura, volume de $42 \mathrm{~L}$, utilizando pozzolana com $3 \mathrm{~mm}$ de diâmetro como meio suporte, para DQO afluente de até $200 \mathrm{mg} / \mathrm{L}$. O autor também verificou que, para valores maiores, houve queda na eficiência de nitrificação devida à competição entre os microrganismos heterotróficos e autotróficos.

SITÔNIO (2001) investigou o desempenho de um BF, em escala bancada, volume útil de 7,2 L, 1,3m de altura, TDH de 5horas usando como material suporte brita e espuma de poliuretano (matrizes de 100x60mm). Esse BF foi utilizado no póstratamento de reator anaeróbio compartimentado (RAC) com $11 \mathrm{~m}^{3}$ de volume, usado para tratamento de esgoto sanitário. O material suporte empregado mostrou-se adequado para formação de biofilme e remoção de sólidos em suspensão, dada sua grande capacidade de absorção. O efluente final revelou excelente qualidade com remoções de $82 \%$ a $86 \%$ de DQO e $\mathrm{DBO}_{5}$ brutas, respectivamente, e nitrificação parcial. A autora atribuiu a baixa eficiência na nitrificação às variações na carga de nitrogênio amoniacal que inibiriam o metabolismo das bactérias nitrificantes.

SOARES (2003), utilizando o BF anterior e empregando os mesmos materiais suporte, propôs melhorias na hidrodinâmica bem como na transferência de OD adotando uma câmara de saturação comumente usada nos sistemas de flotação por ar dissolvido. Sua pesquisa foi dividida em duas etapas: na primeira, denominada Bf1, o autor utilizou o biofiltro usado por SITÔNIO (2001) e na segunda, denominada $\mathrm{Bf}_{2}$, um BF com mesma configuração, porém em uma escala maior.

$\mathrm{O} \mathrm{Bf}_{1}$ foi operado durante 117 dias com TDH de $3 \mathrm{~h}$ com eficiências médias de remoção de $\mathrm{DQO}_{\mathrm{B}}, \mathrm{DBO}_{5}$ e SST de 78\%, 81\% e 84\%, respectivamente, e $49 \%$ de nitrificação. Esta última foi prejudicada devido às variações de $\mathrm{OD}$ no interior do $\mathrm{BF}$. $\mathrm{O}$ $\mathrm{Bf}_{2}$, que foi operado durante 47 dias com TDH de 6 horas, volume útil de $178 \mathrm{~L}, 2 \mathrm{~m}$ de altura e preenchido com matrizes cúbicas de poliuretano de $4 \mathrm{~cm}$ de aresta, apresentou eficiências médias de remoção de $\mathrm{DQO}_{\mathrm{B}}, \mathrm{DBO}_{5}$ e SST de 49\%, 64\% e 51\%, respectivamente. $\mathrm{O}$ autor atribuiu essa baixa eficiência à lavagem do leito efetuada no início da operação que carreou a biomassa ativa para fora do sistema. 
2.6 Padrões da legislação ambiental para lançamento de efluentes

A lei Federal no 9433 de 8 de Janeiro de 1997 instituiu a Política Nacional de Recursos Hídricos, cria o Sistema Nacional de Gerenciamento de Recursos Hídricos, regulamenta o inciso XIX do art. 21 da Constituição Federal, e altera o art. $1^{\circ}$ da Lei ${ }^{\circ}$ 8.001, de 13 de março de 1990, que modificou a Lei $\mathrm{n}^{0} 7.990$, de 28 de dezembro de 1989 sob os seguintes fundamentos, objetivos e instrumentos:

Artigo $1^{\circ}$ - Fundamentos

I- A água é um bem de domínio público;

II- A água é um recurso natural limitado dotado de valor econômico;

III- em situações de escassez, o uso prioritário dos recursos hídricos é o consumo humano e a dessedentação de animais;

IV-A gestão dos recursos hídricos deve sempre proporcionar o uso múltiplo das águas;

V- Bacia hidrográfica e a unidade territorial para implementação da Política Nacional de Recursos Hídricos e atuação do Sistema Nacional de Gerenciamento de Recursos Hídricos;

VI- A gestão dos recursos hídricos deve ser descentralizada e contar com a participação do Poder Público, dos usuários e das comunidades.

Artigo $2^{\circ}$ - Objetivos

I- Assegurar à atual e às futuras gerações a necessária disponibilidade de água, em padrões de qualidade adequados aos respectivos usos;

II- A utilização racional e integrada dos recursos hídricos, incluindo o transporte aquaviário, com vistas ao desenvolvimento sustentável;

III- A prevenção e a defesa contra eventos hidrológicos críticos de origem natural ou decorrente do uso inadequado dos recursos naturais. 
Artigo $5^{\circ}$ - Instrumentos

I- Os Planos de Recursos Hídricos;

II- O enquadramento dos corpos de água em classes, segundo os usos preponderantes da água,

III- A outorga dos direitos de uso de recursos hídricos;

IV-A cobrança pelo uso de recursos hídricos;

V- A compensação a municípios;

VI-O Sistema de Informações sobre Recursos Hídricos.

A resolução CONAMA no 357 de 17 de Março de 2005, como instrumento da Política Nacional de Recursos Hídricos, visa o enquadramento dos corpos d'água em classes, segundo usos preponderantes. Esse enquadramento não está necessariamente baseado nas condições atuais desses corpos, mas nos níveis de qualidade que esses deveriam possuir para atender às necessidades das comunidades. As águas foram dividas em nove classes entres as doces (classes: especial a quatro), salobras (classe: cinco e seis) e salinas (classe: sete e oito). A tabela 2.3 ilustra um resumo das classes com seus respectivos usos preponderantes.

Tabela 2.3- Classificação dos corpos d'água e respectivos usos preponderantes de acordo com a Resolução CONAMA no 357 de 17 de Março de 2005.

\begin{tabular}{|c|c|c|c|c|c|c|c|c|c|}
\hline Uso & \multicolumn{9}{|c|}{ Classe } \\
\hline & Especial & 1 & 2 & 3 & 4 & 5 & 6 & 7 & 8 \\
\hline $\begin{array}{c}\text { Abastecimento Doméstico } \\
\text { Preservação do equilíbrio } \\
\text { natural das comunidades } \\
\text { aquáticas }\end{array}$ & (i) & (ii) & (iii) & (iii) & & & & & \\
\hline $\begin{array}{c}\text { Recreação de contato primário } \\
\text { Proteção das comunidades } \\
\text { aquáticas } \\
\text { Irrigação } \\
\text { Aqüicultura } \\
\text { Dessedentacão de animais }\end{array}$ & & (iv) & (v) & (vi) & & & (vii) & & (vii) \\
\hline $\begin{array}{c}\text { Navegação } \\
\text { Harmonia Paisagística } \\
\text { Usos Menos Exigentes }\end{array}$ & & & & & & & (viii) & & (viii) \\
\hline
\end{tabular}

(i) Sem prévia ou com simples desinfecção; (ii) Após tratamento simplificado; (iii) Após tratamento convencional; (iv) hortaliças que são consumidas cruas e de frutas que crescem rente ao solo e que sejam ingeridas cruas e sem remoção de película; (v) hortaliças e plantas frutíferas; (vi) culturas arbóreas, cerealíferas e forrageiras; (vii) Contato Secundário; (viii) Comercial. 
Os padrões para lançamento de efluentes de qualquer fonte poluidora que direta ou indiretamente podem ser despejados nos corpos d'água estão enunciados no artigo $34^{\circ}$ dessa mesma resolução, apresentados a seguir:

a) $\mathrm{pH}$ entre 5 a 9 ;

b) temperatura: inferior a $40^{\circ} \mathrm{C}$, sendo que a elevação de temperatura do corpo receptor não deverá exceder a $3{ }^{\circ} \mathrm{C}$;

c) materiais sedimentáveis: até $1 \mathrm{ml} /$ litro em teste de 1 hora em cone Imhoff. Para o lançamento em lagos e lagoas, cuja velocidade de circulação seja praticamente nula, os materiais sedimentáveis deverão estar virtualmente ausentes;

d) regime de lançamento com vazão máxima de até 1,5 vezes a vazão média do período de atividade diária do agente poluidor;

e) óleos e graxas:

- óleos minerais até $20 \mathrm{mg} / \mathrm{l}$

- óleos vegetais e gorduras animais até $50 \mathrm{mg} / 1$;

f) ausência de materiais flutuantes;

g) os valores máximos admissíveis de determinadas substâncias estão na tabela 2.4.

Tabela 2.4 - Padrões para lançamento de efluentes.

\begin{tabular}{|c|c|c|c|}
\hline Substância & Concentração & Substância & Concentraçãc \\
\hline Amônia: & $20 \mathrm{mg} / \mathrm{l} \mathrm{N}$ & Mercúrio: & $0,01 \mathrm{mg} / \mathrm{l} \mathrm{Hg}$ \\
\hline Arsênio total: & $0,5 \mathrm{mg} / \mathrm{l} \mathrm{As}$ & Níquel: & $2,0 \mathrm{mg} / \mathrm{l} \mathrm{Ni}$ \\
\hline Bário: & $5,0 \mathrm{mg} / \mathrm{Ba}$ & Prata: & $0,1 \mathrm{mg} / \mathrm{Ag}$ \\
\hline Boro: & $5,0 \mathrm{mg} / \mathrm{l} \mathrm{B}$ & Selênio: & $0,05 \mathrm{mg} / \mathrm{l} \mathrm{Se}$ \\
\hline Cádmio: & $0,2 \mathrm{mg} / \mathrm{l} \mathrm{Cd}$ & Sulfetos: & $1,0 \mathrm{mg} / \mathrm{l} \mathrm{S}$ \\
\hline Cianetos: & $0,2 \mathrm{mg} / \mathrm{l} \mathrm{CN}$ & Sulfito: & $1,0 \mathrm{mg} / \mathrm{l} \mathrm{SO}$ \\
\hline Chumbo: & $0,5 \mathrm{mg} / \mathrm{Pb}$ & Zinco: & $5,0 \mathrm{mg} / \mathrm{Zn}$ \\
\hline Cobre: & $1,0 \mathrm{mg} / \mathrm{l} \mathrm{Cu}$ & Sulfeto de carbono: & $1,0 \mathrm{mg} / \mathrm{l}$ \\
\hline Cromo hexavelente: & $0,5 \mathrm{mg} / \mathrm{l} \mathrm{Cr}$ & Tricloroeteno: & $1,0 \mathrm{mg} / \mathrm{l}$ \\
\hline Cromo trivalente: & $2,0 \mathrm{mg} / \mathrm{l} \mathrm{Cr}$ & Clorofórmio : & $1,0 \mathrm{mg} / \mathrm{l}$ \\
\hline Estanho: & $4,0 \mathrm{mg} / \mathrm{l} \mathrm{Sn}$ & $\begin{array}{c}\text { Tetracloreto de } \\
\text { Carbono: }\end{array}$ & $1,0 \mathrm{mg} / \mathrm{l}$ \\
\hline Índice de fenóis: & $0,5 \mathrm{mg} / \mathrm{l} \mathrm{C} 6 \mathrm{H}_{5} \mathrm{OH}$ & Dicloroeteno: & $1,0 \mathrm{mg} / \mathrm{l}$ \\
\hline Ferro solúvel: & 15,0 mg/l Fe & & \\
\hline Fluoretos: & $10,0 \mathrm{mg} / \mathrm{l} \mathrm{F}$ & & \\
\hline $\begin{array}{l}\text { Manganês } \\
\text { solúvel: }\end{array}$ & 1,0 mg/l Mn & & \\
\hline
\end{tabular}

Fonte: Resolução CONAMA no 357, 17/03/05. 
Deve ser observado que a Resolução CONAMA 357/05 substituiu a Resolução 20/86 que estabelecia os padrões para lançamento de efluentes em nível nacional. Porém, os padrões mais atuais são menos exigentes que os estabelecidos pela antiga resolução. Por exemplo, a concentração de nitrogênio amoniacal estabelecida pela antiga resolução era de $5 \mathrm{mg} / \mathrm{L}$, enquanto que a estabelecida pela nova é de $20 \mathrm{mg} / \mathrm{L}$. Tal mudança pode ter sido efetuada para funcionar como um instrumento motivador para implantação de novas estações de tratamento de efluentes pois, quanto menor a concentração de nitrogênio amoniacal estabelecida, maiores investimentos financeiros devem ser feitos.

A tabela 2.5 apresenta outros padrões de lançamento e de potabilidade para os parâmetros nitrogênio amoniacal e nitrato, respectivamente, estabelecidos por órgãos ambientais do Brasil e de países.

Tabela 2.5 - Padrões de lançamento e/ou potabilidade estabelecidos por órgãos ambientais do Brasil e de outros países.

\begin{tabular}{|c|c|c|}
\hline País & Concentração máxima & Referência \\
\hline Brasil & $10 \mathrm{mg} \mathrm{N}-\mathrm{NO}_{3}{ }^{-} / \mathrm{L}$ (potabilidade) & $\begin{array}{l}\text { Portaria do ministéria da } \\
\text { saúde } \mathrm{n}^{\mathrm{o}} 518 .\end{array}$ \\
\hline Comunidade & $50 \mathrm{mg} \mathrm{N}-\mathrm{NO}_{3}{ }^{-} / \mathrm{L}$ (lançamento) & MATEJU et al. (1992); \\
\hline Européia/OMS & $11,3 \mathrm{mg} \mathrm{N}-\mathrm{NO}_{3}{ }^{-} / \mathrm{L}$ (potabilidade) & $\begin{array}{l}\text { HISCOCK et al. (1991); } \\
\text { KIM et al. (1992). }\end{array}$ \\
\hline Dinamarca & $\begin{array}{c}0,025{\mathrm{mg} \mathrm{N}-\mathrm{NH}_{4}}^{+} / \mathrm{L} \text { para descarga } \\
\text { em rios com peixes }\end{array}$ & HENZE et al. (1997) \\
\hline Itália & $20 \mathrm{mg} \mathrm{N}-\mathrm{NO}_{3}{ }^{-} / \mathrm{L}$ (lançamento) & TILCHE et al. (1999) \\
\hline Coréia & $\begin{array}{c}60 \mathrm{mg} \mathrm{N}-\mathrm{NT} / \mathrm{L} \text { (lançamento) } \\
10{\mathrm{mg} \mathrm{N}-\mathrm{NO}_{3}}^{-} / \mathrm{L} \text { (potabilidade) }\end{array}$ & CHOI et al. (2004) \\
\hline EUA/EPA & $\begin{array}{c}15 \mathrm{mg} \mathrm{N}-\mathrm{NT} / \mathrm{L} \text { (potabilidade) } \\
10 \mathrm{mg} \mathrm{N}-\mathrm{NO}_{3}^{-} / \mathrm{L} \text { (potabilidade) }\end{array}$ & MATEJU et al. (1992) \\
\hline
\end{tabular}

Fonte: Adaptado IAMAMOTO (2006) 


\section{Objetivos}

3.1 Objetivo Geral.

Esta pesquisa teve por objetivo geral, estabelecer uma nova configuração de biofiltro aerado submerso utilizado para tratamento de efluente de reator UASB, promovendo nitrificação e desnitrificação em um único sistema.

\subsection{Objetivos Específicos.}

Para que o objetivo geral dessa pesquisa fosse alcançado, os seguintes objetivos específicos foram estabelecidos:

- Construir três biofiltros, em escala de bancada e operados em série, para avaliar a seqüência mais adequada para favorecer nitrificação e desnitrificação. e investigar a eficiência de desnitrificação nesses biofiltros seqüenciais com e sem recirculação entre os ambientes anóxico e aeróbio.

- Verificar a viabilidade do lodo acumulado no sistema e do esgoto sanitário como fontes de carbono para desnitrificação.

- Avaliar a eficiência do novo biofiltro proposto, em escala piloto, na remoção de nitrogênio. 


\section{Material e Métodos}

Neste capítulo é apresentada a metodologia empregada no desenvolvimento da nova configuração de biofiltro aeróbio submerso utilizado no pós-tratamento do efluente de reator UASB.

Inicialmente, será apresentada a concepção preliminar do projeto para construção da nova configuração. Em seguida, serão descritas as etapas necessárias para implementação desse projeto. Tais etapas deram origem à configuração definitiva do $\mathrm{BF}$, produzindo um sistema capaz de promover nitrificação e desnitrificação em um único sistema. Detalhes quanto ao material utilizado para construção dos reatores utilizados em cada etapa, parâmetros de operação como: tempo de detenção hidráulica, vazão, pontos de amostragem, vazão de ar e alcalinização, procedimentos utilizados nas análises, dentre outros, também serão descritos nesse capítulo.

Um espaço também foi reservado para mostrar as dificuldades enfrentadas durante a execução dessa pesquisa, pois estas exerceram influência direta no resultado final desse trabalho. 


\subsection{Concepção inicial do novo biofiltro.}

A concepção inicial da nova configuração de BF proposta foi idealizada visando pós-tratamento do efluente de reator UASB promovendo, basicamente, remoção da matéria orgânica carbonácea remanescente do efluente desse reator, nitrificação e desnitrificação em um único sistema. Assim, a associação UASB+BF seria uma atraente combinação para compor um sistema de tratamento, secundário e terciário, de pequenas ou até de grandes comunidades caso estudos futuros, em escala piloto, comprovassem sua eficácia. Essa combinação resultaria em menor produção de lodo e menor consumo de energia elétrica, comparando-a a uma estação de lodos ativados, por exemplo, além de menor área para implantação conferida pela configuração compacta do BF. Além dessas vantagens, o processo de tratamento biológico aderido em meio suporte, pode favorecer menor tempo de detenção hidráulica quando comparado a sistemas de crescimento suspenso.

Diante dessas inferências foi proposta a construção de um BF composto basicamente por três reatores constituídos de tubos de PVC concêntricos, operados como reatores em série. Esses reatores, denominados R1, R2 e R3_foram idealizados para diferentes finalidades: R1 - remoção de DBO e nitrificação parcial; R2nitrificação, desnitrificação e remoção da DBO remascente do reator R1; R3 desnitrificação. O efluente do reator UASB juntamente com ar comprimido, seria injetado na base do reator R1 que teria fluxo ascendente. Nesse tubo, seria fornecido oxigênio dissolvido suficiente para remoção de DBO e para sobejar para o reator R2. O efluente do reator R1, com menor carga orgânica carbonácea e OD em torno de 4,5 $\mathrm{mg} / \mathrm{L}$, entraria pelo topo do reator R2 no qual ocorreria nitrificação e em fluxo descendente, caminharia para a base do reator R3. A concentração de OD fornecida ao sistema seria controlada para que dentro do reator R2 fosse totalmente consumida, ao longo da altura, para que condições anóxicas prevalecessem próximo à entrada do reator R3. Logo, o efluente do reator UASB, após o pós-tratamento realizado pelo novo BF estaria em condições de atender às exigências ambientais vigentes, minimizando também problemas oriundos do lançamento de esgoto sanitário, em cursos d'água, como a eutrofização. As demais características do projeto inicial do BF estão mostradas na figura 4.1 . 


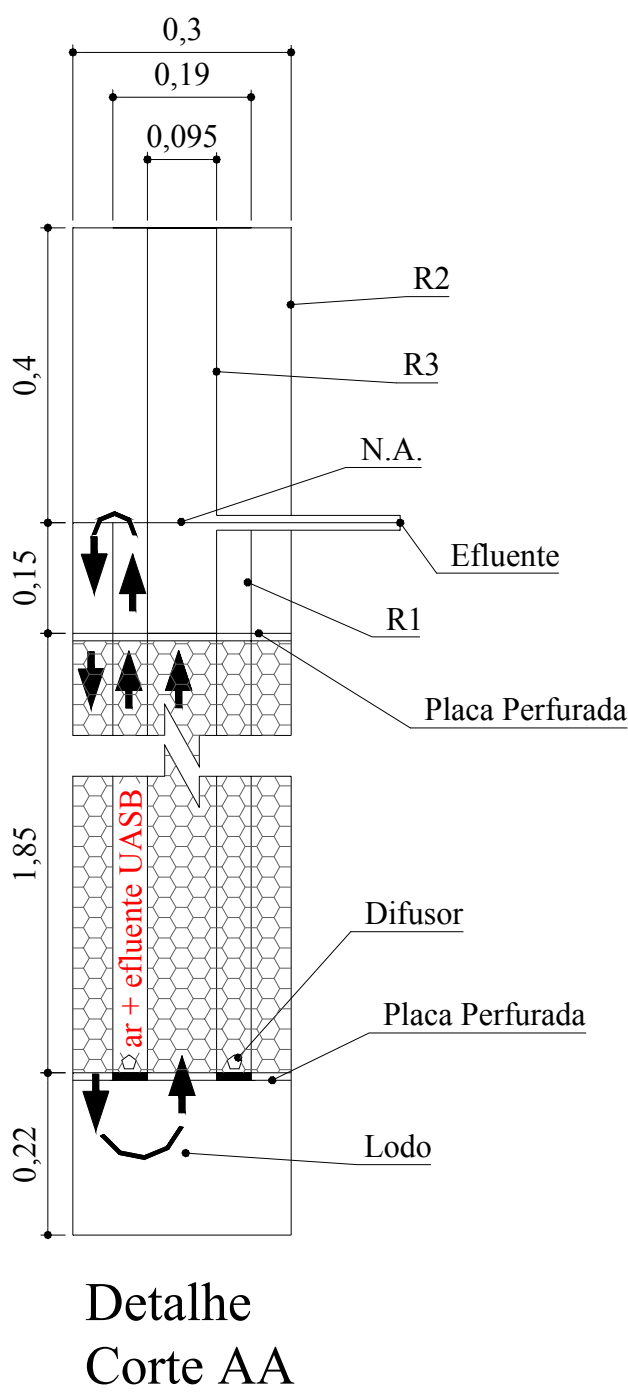

Legenda:

Entrada de Esgoto

Entrada de Ar

4 Sentido do fluxo

Suporte

$\mathrm{A}$

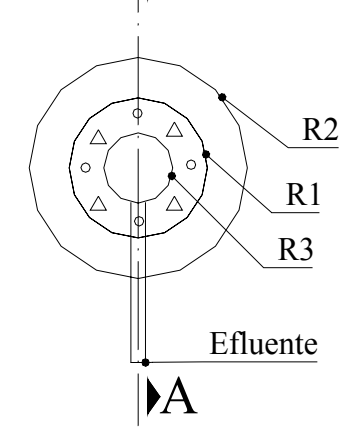

Planta

Cotas em metros

Figura 4.1 - Detalhes do biofiltro idealizado.

No entanto, antes que o BF idealizado fosse construído e colocado em operação foi proposto que o conjunto dos três tubos que formariam sua estrutura básica fosse divido em três reatores de menor escala, também operados em série, possibilitando assim, maior flexibilidade caso eventuais alterações de projetos fossem necessárias. Esses reatores também foram denominados R1, R2 e R3 e tiveram, a princípio, as mesmas finalidades descritas anteriormente.

Inicialmente, a ordem da série em que esses reatores foram dispostos, ou seja, um em relação ao outro, foi denominada seqüência I (R1, R2, R3). Essa seqüência, porém, apresentou baixa eficiência em desnitrificação por motivos que serão apresentados posteriormente. Assim, na tentativa de melhorar tal desempenho, os 
reatores foram rearranjados em uma nova ordem denominada seqüência II (R2, R1, R3) com recirculação entre R1 e R2. Dessa última seqüência surgiu, então, a configuração definitiva do BF proposto nessa pesquisa. A figura 4.2 apresenta o fluxograma do desenvolvimento da nova configuração do BF.

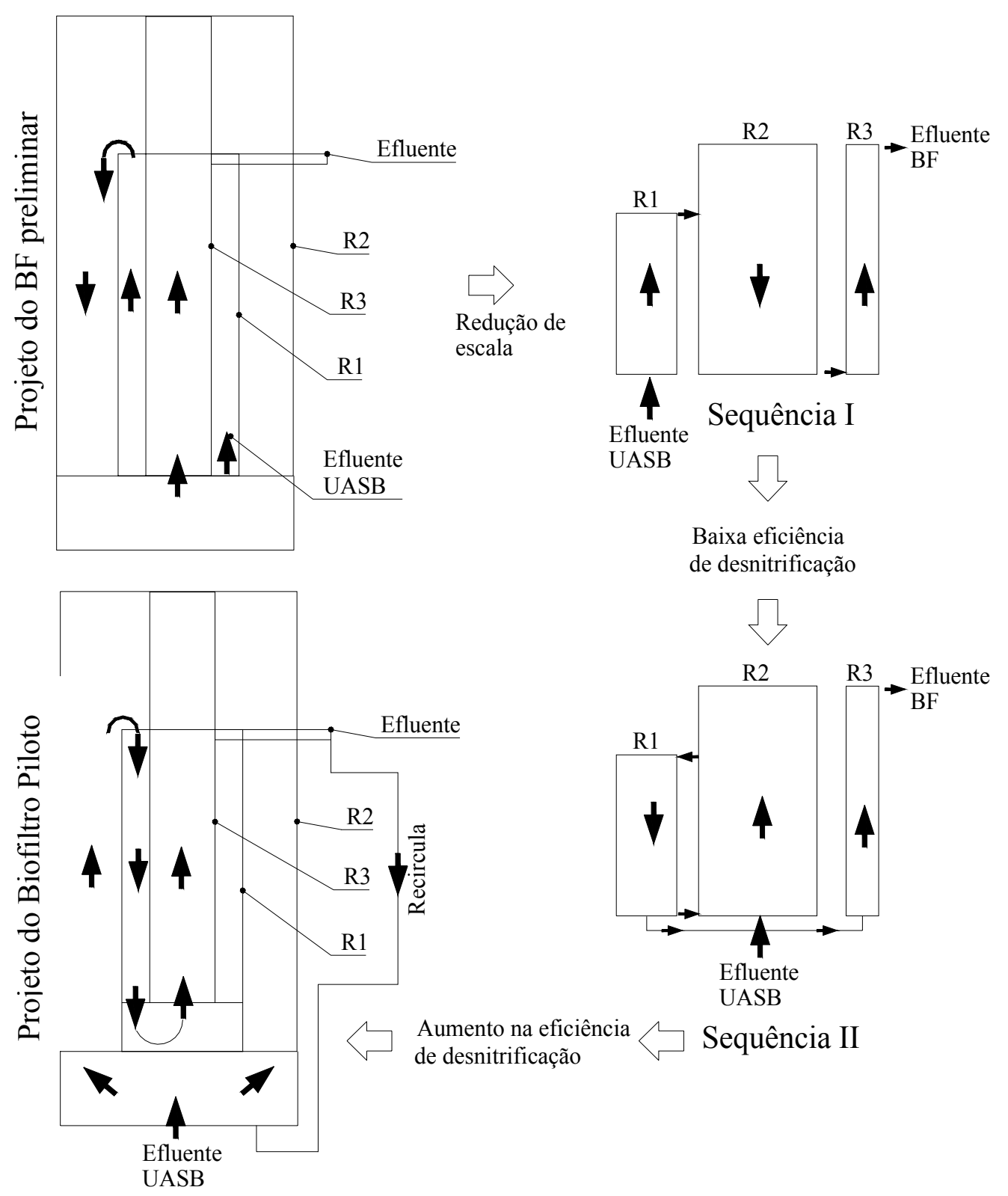

Figura 4.2 - Fluxograma do desenvolvimento do BF. 


\subsection{Seqüência I}

Os três reatores de volumes e dimensões pré-definidas, em menor escala, foram construídos com tubos de PVC e colocados em operação, para verificar o desempenho no pós-tratamento do efluente de reator UASB. Essa seqüência está melhor detalhada conforme ilustração da figura 4.3 As características desse conjunto de reatores estão apresentadas na tabela 4.1 .

Tabela 4.1 - Principais características dos reatores utilizados na sequência I.

\begin{tabular}{cccc}
\hline & \multicolumn{4}{c}{ Características Físicas } & R3 \\
\hline Reator & R1 & R2 & 53,7 \\
Diâmetro (cm) & 53,7 & 75,0 & 1,45 \\
Altura (m) & 2,10 & 2,00 & 3 \\
Volume útil (L) & 4 & 8 & PVC \\
Material & PVC & PVC & 1 \\
Vazão afluente (L/h) & 1 & 1 & 3 \\
TDH (h) & 4 & 8 & Anéis de poliestireno \\
Material Suporte & Anéis de poliestireno & Anéis de poliestireno & 1,35 \\
Altura do ponto de & 2,00 & 0,25 & \\
amostragem (m) & & & Ascendente \\
Sentido do Fluxo & Ascedente & Descendente & \\
\hline
\end{tabular}

Os reatores foram montados em uma sala anexa à ETE do campus da USP de São de Carlos. Essa estação de tratamento foi concebida a partir de pesquisas realizadas no Departamento de Hidráulica e Saneamento, cujo projeto foi coordenado pelo prof. Dr. José Roberto Campos. O reator UASB, cujo efluente foi objeto dessa pesquisa, possui $18 \mathrm{~m}^{3}, 6 \mathrm{~m}$ de altura e atualmente estava operando com vazão de $1670 \mathrm{~L} / \mathrm{h}$, tratando parte do esgoto sanitário oriundo da EESC e da população circunvizinha do campus. A figura 4.4-a apresenta a foto do reator UASB e a 4.4 -b, da sala anexa à ETE na qual o experimento foi instalado. 


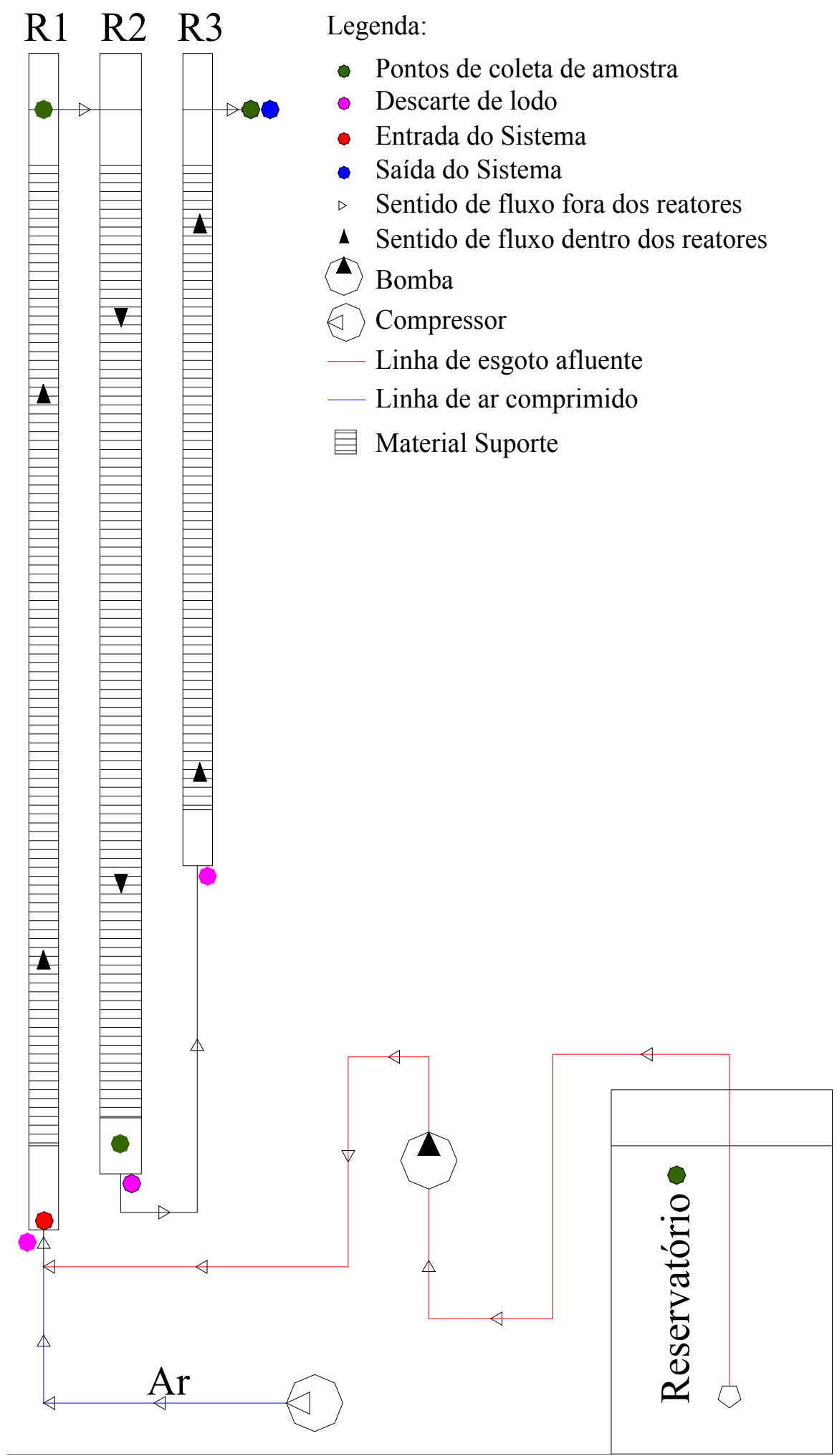

Figura 4.3 - Bancada experimental e esquema de funcionamento dos reatores na Seqüência I. 


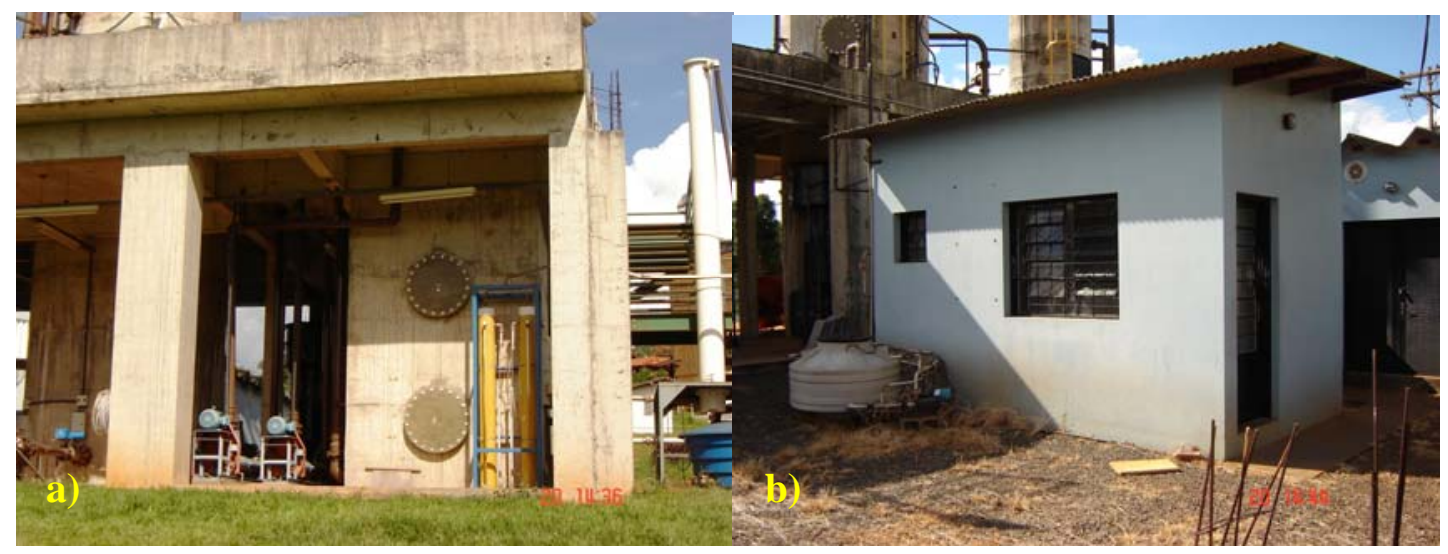

Figuras 4.4 (a) e (b)- Fotografia do reator UASB e da sala na qual os reatores estão instalados.

O efluente oriundo do reator UASB era coletado por sifão e armazenado em um reservatório com capacidade total de 250L. Esse volume era suficiente para alimentar o sistema de reatores por um período de até 10 dias. Porém, tal volume era reposto em dias alternados para que não ocorressem grandes alterações das características do efluente a ser tratado.

A alcalinização com cal hidratada, utilizado na construção civil, na proporção de $0,5 \mathrm{~g}$ por litro de esgoto, foi efetuada para que o $\mathrm{pH}$ afluente aos reatores fosse mantido próximo a 7,5. As impurezas da cal utilizada certamente influenciaram o alto valor da concentração encontrada. Como uma quantidade de cal sempre ficava depositada no fundo do reservatório, o alcalinizante era adicionado somente quando ocorria queda do $\mathrm{pH}$ no afluente ao sistema.

A quantidade de alcalinizante foi determinada segundo procedimento descrito a seguir:

o Foi colocado 1 litro de amostra do efluente do reator UASB em um béquer e deixado sob agitação constante.

o Uma sonda foi imersa nessa amostra para que a variação do $\mathrm{pH}$ fosse registrada durante todo o procedimento.

o Foi pesado $100 \mathrm{~g}$ de alcalinizante.

- A massa de alcalinizante pesada foi sendo adicionada aos poucos na amostra em agitação até que o $\mathrm{pH}$ atingiu o valor desejado.

o A massa restante do alcalinizante foi novamente pesada e seu valor subtraído da massa inicial, 100g. 
o A razão entre a massa de alcalinizante utilizada e o volume tomado da amostra forneceu a massa de alcalinizante que foi adicionada ao sistema quando necessário.

Do reservatório, o efluente era bombeado por uma bomba dosadora micro processada e conduzido até a base do reator R1 no qual também era injetado ar comprimido para fornecimento de oxigênio dissolvido ao sistema de reatores. A vazão de ar, de $100 \mathrm{~L} / \mathrm{h}$, fornecida por compressor, era controlada por registro de agulha e mensurada em rotâmetro localizado na entrada de ar do sistema. Para facilitar a transferência de oxigênio para a fase líquida do reator, foi empregado difusor cerâmico utilizado em aquários. Da base do reator R1 o efluente seguia em fluxo ascendente até a saída que era conectada à entrada do reator R2. Da entrada do reator R2 o efluente seguia em fluxo descendente à saída que era conectada à entrada do reator R3. Do reator R3, o efluente seguia, em fluxo ascendente à saída desse reator onde era coletado como efluente na fase final do tratamento.

O reator R1 teve o papel de remoção da carga orgânica e nitrificação parcial do esgoto afluente. O reator R2 recebia o efluente do reator R1, com carga orgânica menor devido à remoção ocorrida no reator R1 e oxigênio dissolvido em concentração suficiente para completar a nitrificação. A altura e volume do reator R2 foram projetados objetivando que, ao longo do escoamento, todo oxigênio dissolvido fosse consumido no processo de nitrificação. Assim, o efluente do reator R2 entrava no reator R3, sem OD e com todo nitrogênio afluente ao sistema oxidado a nitrato, dando início, então, ao processo de desnitrificação.

O lodo, acumulado no fundo dos reatores R2 e R3, não foi descartado durante a operação da seqüência I na tentativa de que o mesmo fosse utilizado como fonte de carbono para as bactérias desnitrificantes.

Para viabilizar a partida do sistema, os reatores foram inoculados com lodo aeróbio adaptado a altas concentrações de nitrogênio amoniacal, até $500 \mathrm{mg} / \mathrm{L}$ de $\mathrm{N}$ $\mathrm{NH}_{3}$, utilizado no projeto de pesquisa de IAMAMOTO (2006) sob orientação do professor Dr. Eugênio Foresti. A quantidade desse lodo era de 2,5 litros e este foi submetido a um período de adaptação ao substrato, no caso, o efluente do reator UASB. Esse lodo foi colocado sob aeração constante e alimentado, em batelada, com um volume crescente do efluente anaeróbio. Inicialmente foi misturado ao volume de lodo, 0,5 litro de esgoto e após $24 \mathrm{~h}$ de aeração, o aerador foi desligado para que o lodo 
sedimentasse. Após 1 hora, o lodo estava sedimentado e o sobrenadante foi retirado por sifão. Foi adicionado novamente 1 litro de esgoto e repetido o mesmo procedimento por mais 5 dias. A partir disso, esse lodo foi distribuído entre os três reatores na seguinte proporção: 1,0 litro para o reator R1, 1,0 litro para o reator R2 e 0,5 litro para o reator R3.

A partida do sistema foi efetuada em março de 2006 com vazão afluente de aproximadamente $0,5 \mathrm{~L} / \mathrm{h}$. Após 30 dias da partida foi iniciada a rotina de análises laboratoriais para verificar o desempenho do conjunto de reatores. A partir daí, a vazão foi regulada para $1 \mathrm{~L} / \mathrm{h}$ e os reatores operaram, respectivamente, com tempos de detenção hidráulica de aproximadamente 4, 8 e 3 horas para os reatores R1, R2 e R3. No período de adaptação dos reatores, o reator R2 também recebeu ar comprimido em sua base para garantir a colonização de microrganismo nitrificantes ao longo de todo material filtrante.

Durante o período de operação o sistema sofreu uma série de intercorrências que prejudicou a rotina de análises. Um tópico específico tratará desse assunto. Posto isso, durante a operação o sistema sofreu uma sobrecarga tóxica advinda do efluente do reator UASB que foi fatal aos microrganismos presentes nos reatores. Tal fato foi refletido em todos os resultados obtidos dos reatores que tiveram seus desempenhos totalmente prejudicados na nitrificação e na remoção de matéria orgânica. Outros pesquisadores da ETE também foram prejudicados por tal sobrecarga. Diante disso, o sistema foi inoculado, novamente, com lodo anaeróbio de descarte do reator UASB. Esse foi coletado e adicionado diretamente aos reatores nos seguintes volumes: 1 L para o reator R1, 3 L para o reator R2 e 1 L para o reator R3. A vazão afluente ao sistema foi novamente reduzida à metade e foi aguardado novo período de colonização e adaptação dos microrganismos por 15 dias, e a rotina de análises foi retomada.

A opção pelo lodo anaeróbio foi tomada pelo caráter emergencial em que o sistema se encontrava e pela indisponibilidade de lodo aeróbio nas proximidades do local onde a pesquisa foi realizada. Microrganismos facultativos certamente estavam presentes no lodo utilizado, pois o sistema rapidamente recuperou o equilíbrio dinâmico aparente de operação. 


\subsection{Seqüência II.}

Após certo período de operação dos reatores na Seqüência I o sistema revelou alto desempenho na remoção de matéria orgânica e no processo de nitrificação. Conforme o plano inicial, os reatores R1 e R2 estavam provendo suas respectivas funções. No reator R1, a matéria orgânica carbonácea era quase que totalmente removida e o nitrogênio amoniacal $\left(\mathrm{N}_{-} \mathrm{NH}_{3}\right)$ era, em grande parte, convertido para nitrato. $\mathrm{O}$ reator $\mathrm{R} 2$ estava funcionando para complementar a nitrificação iniciada no reator R1, conforme planejado. Porém, o reator R3 ainda era deficiente no processo de desnitrificação. A provável causa dessa deficiência foi atribuída à quantidade inadequada de fonte de carbono aos microrganismos desnitrificantes.

$\mathrm{Na}$ hipótese de empregar uma fonte externa de carbono, o que em escala real poderia acarretar em aumento de custos de operação do BF, foi pensado em utilizar o próprio esgoto afluente ao sistema em um processo de recirculação tipo pré-anóxico. A partir disso, uma nova seqüência de fluxo entre reatores foi formulada, e as devidas mudanças foram implantadas no sistema, dando origem a Seqüência II (R2, R1, R3). As características do sistema utilizado na seqüência II estão apresentadas nas tabelas 4.2.

Tabela 4.2 - Principais características dos reatores utilizados na sequência II.

\begin{tabular}{cccc}
\hline & \multicolumn{4}{c}{ Características Físicas } & R3 \\
\hline Reator & R1 & R2 & 53,7 \\
Diâmetro (mm) & 53,7 & 75,0 & 1,45 \\
Altura (m) & 2,10 & 2,00 & 3 \\
Volume útil (L) & 4 & 8 & PVC \\
Material & PVC & PVC & 1 \\
Vazão afluente (L/h) & 1 & 1 & 3 \\
TDH (h) & 4 & 8 & Anéis de poliestireno \\
Material Suporte & Anéis de poliestireno & Anéis de poliestireno & 1,35 \\
Altura do ponto de & 2,00 & 0,25 & \\
amostragem (m) & & & Ascendente \\
Sentido do Fluxo & Descendente & Ascendente &
\end{tabular}

O esquema de funcionamento dos reatores e a bancada experimental, nessa nova seqüência estão apresentados na figura 4.5. 


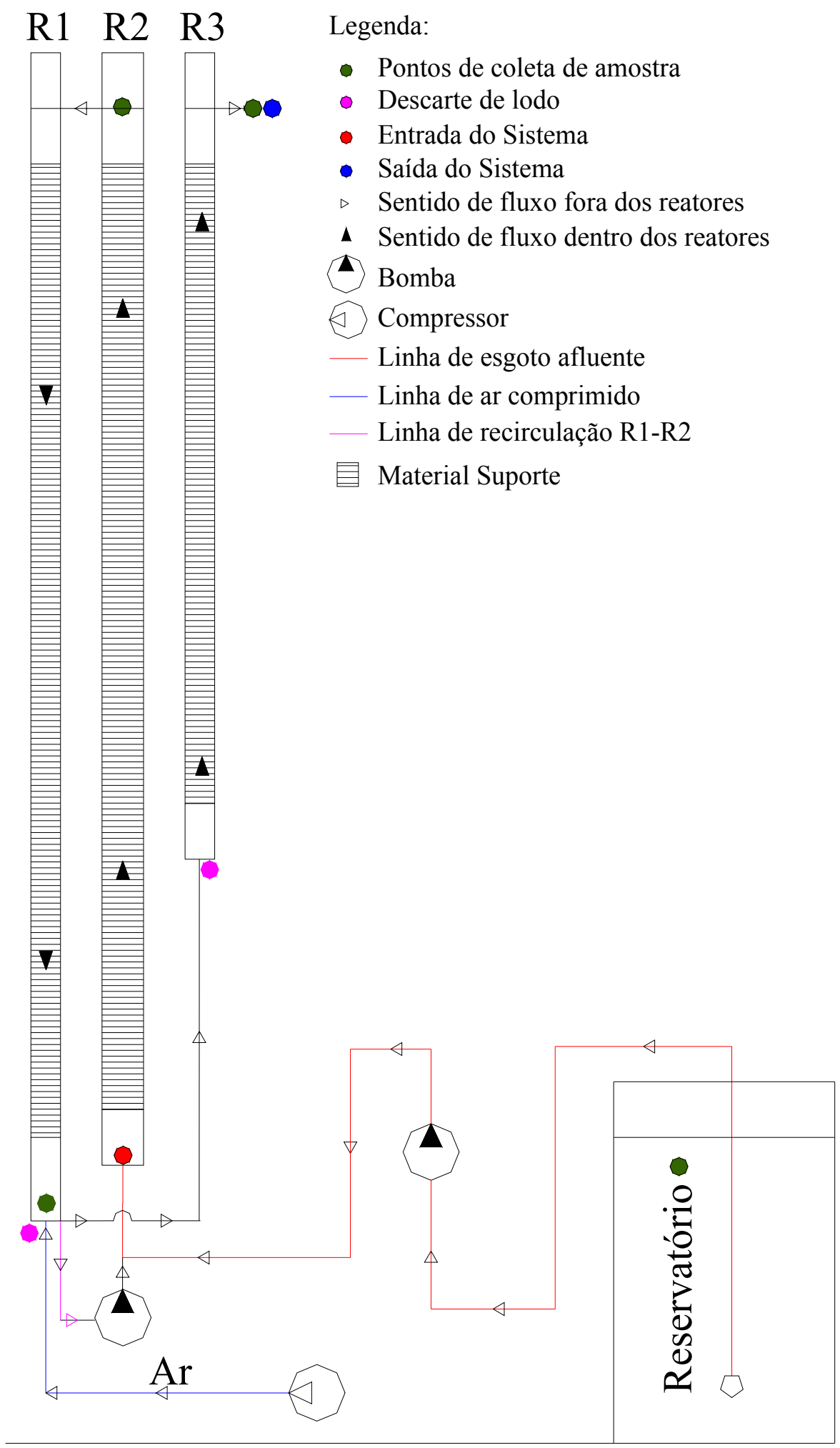

Figura 4.5 - Bancada experimental e esquema de funcionamento dos reatores na Seqüência II. 
$\mathrm{Na}$ concepção dessa nova sequência, o esgoto afluente entrava pela base do reator R2, e em fluxo ascendente seguia à saída conectada à entrada do reator R1 na base do qual, ar comprimido era injetado através de difusor cerâmico (modelo utilizado em aquários) para auxiliar a transferência de oxigênio ao meio líquido.

Da entrada do reator R1 o esgoto, em fluxo descendente, chegava a base do mesmo onde parte era recirculado para a base do reator R2 e outra parte seguia para a entrada do reator R3. Nesse último, em fluxo ascendente o efluente pós-tratado do sistema, era coletado na saída desse reator localizada no topo do mesmo. A nitrificação foi efetuada predominantemente no reator R1 que teve seu efluente recirculado para o reator R2 onde ocorreu desnitrificação.

O leito do reator R2 teve condições suficientes para desempenhar seu papel no processo de tratamento pois oferecia, ao efluente recirculado do reator R1, ambiente anóxico e fonte de carbono. Esse fato será corroborado pelos resultados apresentados posteriormente. $\mathrm{O}$ reator $\mathrm{R} 3$ foi empregado para remoção de sólidos do sistema produzindo efluente bem clarificado.

ARAÚJO JR. (2006), em sua pesquisa que empregava BFs para remoção de nitrogênio de efluente industrial, também efetuou recirculação entre dois reatores para promover a desnitrificação em sistema de biofiltros em série. Com o aumento de $\mathrm{R}_{\mathrm{c}}$ de 1 para 3,5 o autor verificou notável melhora do sistema na conversão de nitrato $\left(\mathrm{N}^{-} \mathrm{NO}_{3}{ }^{-}\right)$ a nitrogênio gasoso.

Posto isso, a pesquisa, nessa sequência, foi divida em três etapas para avaliar o desempenho do sistema no processo da desnitrificação.

$\mathrm{Na}$ etapa I o sistema operou com $\mathrm{R}_{\mathrm{c}}$ igual a 1 sendo utilizada como fonte de carbono o efluente do reator UASB armazenado no reservatório de entrada.

A razão de recirculação $\left(R_{c}\right)$ foi aumentada de 1 para 2,65, na etapa II, e o efluente do reator UASB continuou sendo utilizado como fonte de carbono sem qualquer diluição.

$\mathrm{Na}$ etapa III o valor de $\mathrm{R}_{\mathrm{c}}$ da etapa II foi mantido porém, a fonte de carbono empregada foi composta por uma diluição efetuada, no reservatório de entrada do sistema, na proporção de $40 \%$ de esgoto bruto e $60 \%$ de efluente do reator UASB. As condições de operação em cada etapa realizada na sequência II estão na tabela 4.3. 
Tabela 4.3 - Condições de operação dos reatores utilizados em cada etapa da seqüência II.

\begin{tabular}{|c|c|c|c|}
\hline \multicolumn{4}{|c|}{ Condições de Operação na Sequência II } \\
\hline Etapas & $\mathbf{I}$ & II & III \\
\hline $\begin{array}{l}\text { Vazão de Recirculação } \\
\text { entre R1 e R2 (m } / \mathbf{h})\end{array}$ & 1 & 2,65 & 2,65 \\
\hline Razão de Recirculação & 1 & 2,65 & 2,65 \\
\hline Fonte de Carbono & $\begin{array}{l}100 \% \text { Efluente } \\
\text { UASB }\end{array}$ & $\begin{array}{c}100 \% \text { Efluente } \\
\text { UASB }\end{array}$ & $\begin{array}{c}60 \% \text { efluente } \\
\text { UASB }+40 \% \text { de } \\
\text { esgoto bruto }\end{array}$ \\
\hline
\end{tabular}

$\mathrm{Na}$ figura 4.6 estão representados os reatores, instalados na sala anexa a ETE da USP de São Carlos, que foram empregados nas duas seqüências de reatores.

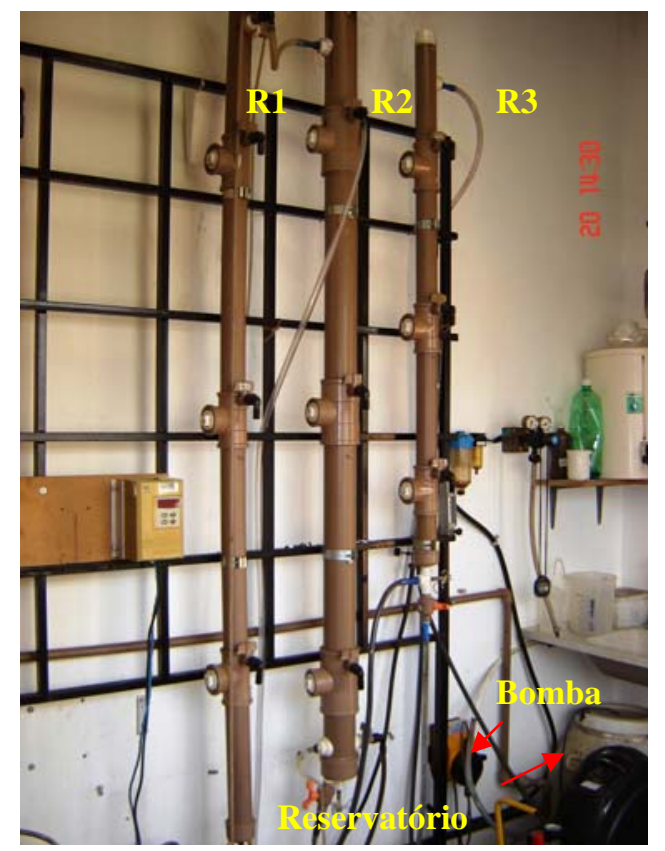

Figura 4.6 - Fotografia dos reatores empregados nas duas seqüências da etapa I.

\subsection{Configuração do Biofiltro Piloto}

A configuração definitiva do novo BF surgiu após a finalização da etapa III da sequência II. Essa etapa mostrou que a configuração proposta era viável para realizar o pós-tratamento do efluente do reator UASB, efetuando nitrificação e desnitrificação em um único reator e servindo, também, de base técnica para construção do Biofiltro Piloto. Uma representação esquemática do Biofiltro Piloto está representado na figura 4.7. 


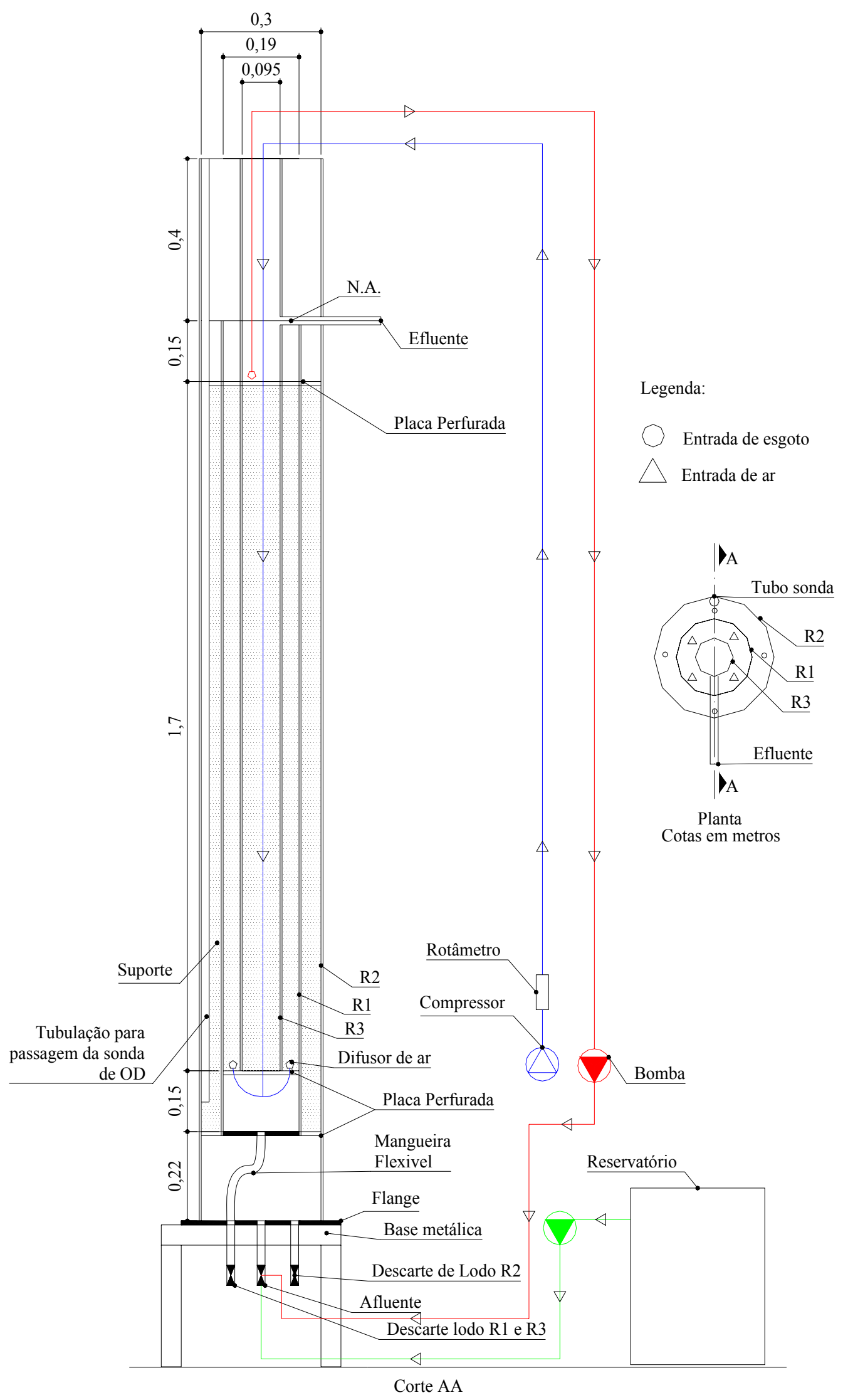

Figura 4.7 - Representação esquemática do Biofiltro Piloto. 
O BF na configuração definitiva, operou dentro das condições estabelecidas na etapa III, da sequência II porém, devido ao aumento da escala, a vazão afluente foi aumentada para $10 \mathrm{~L} / \mathrm{h}$. O efluente do reator UASB era coletado e armazenado em um reservatório, alcalinizado, quando necessário, e daí bombeado para o reator R2, de fluxo ascendente. $\mathrm{O}$ efluente do reator $\mathrm{R} 2$ entrava no topo do reator $\mathrm{R} 1$, onde era aerado com vazão de ar afluente de $400 \mathrm{~L} / \mathrm{h}$, e seguia para sua base em fluxo descendente. O efluente do reator R1 entrava pela base do reator R3 e em fluxo ascendente, seguia para a saída do sistema.

Cada um dos reatores componentes da configuração definitiva do BF foram aplicados nos mesmos papeis que desempenharam os reatores da sequência III, no processo de remoção de nitrogênio.

No topo do reator R3 o efluente do sistema era bombeado para a entrada do reator R2, ocorrendo recirculação do esgoto pós-tratado na razão $\mathrm{R}_{\mathrm{c}}$ igual a 2,65.

Um tubo perfurado foi fixado no interiro do reator R2 para passagem de uma sonda de OD para verficar se o ambiente de fato estava anóxico.

As características fisicas e de operação dos reatores do Biofiltro Piloto estão apresentadas na tabela 4.4 .

Tabela 4.4 - Principais características dos reatores utilizados na composição do Biofiltro Piloto.

\begin{tabular}{cccc}
\hline \multicolumn{4}{c}{ Características Físicas } \\
\hline Reator & R1 & R2 & R3 \\
Diâmetro útil (cm) & $19,0-9,5=\mathbf{9 , 5}$ & $30,0-19,0=\mathbf{1 1 , 0}$ & 9,5 \\
Altura (m) & 2 & 2,22 & 2 \\
Volume útil (L) & 40 & 90 & 11 \\
Material & PVC & PVC & PVC \\
Vazão afluente & 10 & 10 & 10 \\
(L/h) & & & 1,1 \\
TDH (h) & 4 & 9 & Anéis de \\
Material Suporte & Anéis de & Anéis de & poliestireno \\
Altura do ponto de & poliestireno & poliestireno & 2,00 \\
amostragem (m) & - & - & Ascendente \\
Sentido do Fluxo & Descendente & Ascendente & \\
\hline
\end{tabular}


É possível observar pelos dados apresentados na tabela 4.4 que a escala dos reatores que constituíram o Biofiltro Piloto foi aumentada em aproximadamente dez vezes em relação aos reatores utilizados na seqüência II. A exceção foi devida somente ao reator R3 que teve sua escala aumentada em aproximadamente três vezes, por razões da adequação concêntrica dos três reatores. Como o pós-tratamento ocorreu predominantemente nos reatores R1 e R2, na seqüência II (ver capítulo 5) acreditou-se que tal adequação não prejudicaria a configuração do Biofiltro Piloto. As fotografias da montagem do Biofiltro Piloto encontram-se na figura 4.8. A construção do BF durou aproximadamente 60 dias e o sistema foi instalado na mesma sala anexa à ETE onde os reatores seqüenciais foram operados.

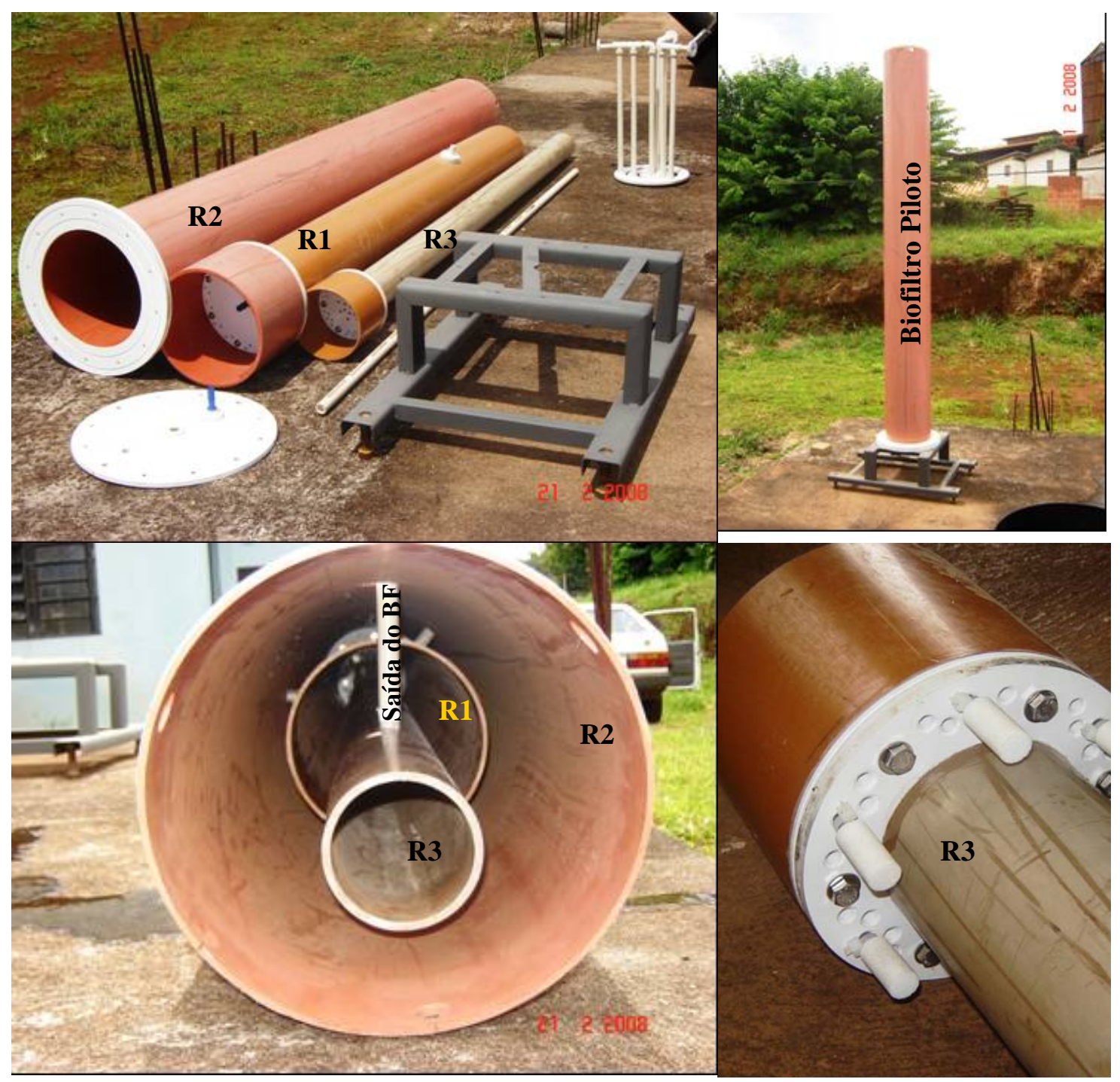

Figura 4.8 - Fotografias da montagem do Biofiltro Piloto. 
A partida do sistema foi efetuada com inoculação com lodo proveniente dos reatores utilizados na seqüência II. A biomassa desses reatores foi retirada a partir da lavagem do material suporte do sistema utilizando efluente do reator UASB.

Esse lodo retirado de cada reator, misturado ao efluente UASB, foi quantificado e inoculado nos respectivos reatores de maior escala, componentes do Biofiltro Piloto. Assim, 4 L de lodo foi retirado do reator R1 da seqüência II e adicionado ao reator R1 da configuração definitiva. $\mathrm{O}$ mesmo procedimento foi efetuado para os reatores $\mathrm{R} 2 \mathrm{e}$ R3 com 9 e 1,5 litros, respectivamente.

Para adaptação do inóculo ao novo ambiente, a vazão afluente ao BF foi ajustada para $2 \mathrm{~L} / \mathrm{h}$ e mantida por 14 dias. Ao final desse período, a vazão foi aumentada, diariamente, em $1 \mathrm{~L} / \mathrm{h}$ até o valor de $10 \mathrm{~L} / \mathrm{h}$ que foi fixado durante o restante do experimento.

Foi escolhido material suporte, inerte e com aspecto favorável à fixação e colonização da biomassa responsável pelo pós-tratamento nos reatores durante toda pesquisa. Esse material, constituído de eletroduto flexível de poliestireno de 0,01m de diâmetro e fracionado em anéis de $0,01 \mathrm{~m}$ de comprimento, foi utilizado por RODRÍGUEZ (2006) e colocado no sistema em quantidade suficiente para preencher os reatores. Esse material apresentou características apropriadas para tal emprego, apresentando superfície corrugada interessante para fixação celular e área específica superficial aproximadamente igual a $135 \mathrm{~m}^{2} / \mathrm{m}^{3}$ (RODRÍGUEZ, 2006). A figura 4.9 mostra a fotografia dos anéis de poliestireno empregados para fixação dos microrganismos.

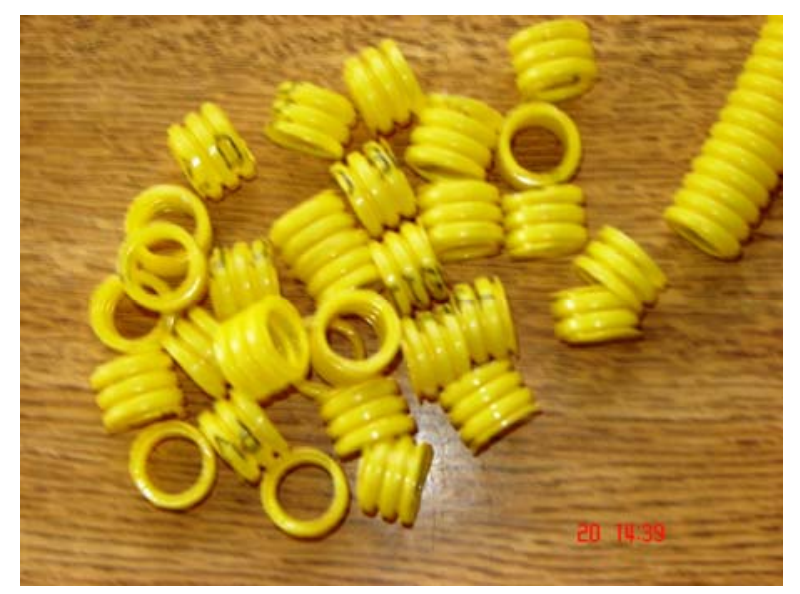

Figura 4.9 - Fotografia do material suporte empregado na pesquisa 
4.5 Rotina de operação e análises físico-químicas.

A proposta da nova configuração revelou simplicidade operacional em todo o experimento. Em biofiltros convencionais, a necessidade diária de lavagem do leito filtrante é um procedimento operacional que deve ser executado para o correto funcionamento do sistema.

Nessa pesquisa, apenas o descarte do lodo depositado no fundo dos reatores era efetuado em dias alternados somente na sequência II, uma vez que o lodo excedente não mais era utilizado como fonte de carbono. Em um sistema em escala real, esse lodo seria encaminhado novamente para o reator UASB evitando assim, aumento de custos de implantação da estação, com dispositivos de secagem e disposição de lodo do BF. Na sequência I e na operação do Biofiltro Piloto o descarte de lodo não foi efetuado. No caso do BF a lavagem não foi efetuada por não ter ocorrido aumento significativo do sólidos no efluente.

Durante a operação da sequência I as amostras foram coletadas nas respectivas saídas de cada reator e entrada do sistema, confome é possível notar na figura 4.3. Os pontos de amostragem da sequência II também estão apresentados na figura 4.5. A amostragem da sequência II foi realizada somente na entrada e na saída do sistema, respectivamente, em cada etapa, a partir do momento em que o sistema entrava em equilíbrio dinâmico aparente. Esse procedimento foi adotado visando economia de reagentes químicos sem que os resultados da eficiência global do sistema fossem prejudicados. Na operação do Biofiltro Piloto, as amostras também foram coletadas somente nos pontos de entrada e saída do sistema como será apresentado na figura 4.6.

As amostras coletadas eram encaminhadas diretamente para análises laboratoriais feitas uma vez na semana nos pontos já mencionados.

Os parâmetros físico-químicos, bem como a frequência de análises realizadas em cada fase da pesquisa, são encontrados nas Tabelas 4.5, 4.6 e 4.7. Nem todos parâmetros foram avaliados nos biofiltros sequenciais e no Biofiltro Piloto por razões que serão expostas mais adiante.

Todos os procedimentos analíticos foram adotados segundo Standard Methods for the Examination of Water and Wastewater (APHA, 1995). 
Tabela 4.5 - Rotina de ensaios para monitoramento da eficiência na seqüência I.

\begin{tabular}{l|c|c|c}
\hline \multicolumn{1}{c|}{ Parâmetros } & Unidades & Freqüências & $\begin{array}{c}\text { Procedimento } \\
\mathbf{n}^{\mathbf{o}} .\end{array}$ \\
\hline Temperatura & ${ }^{\circ} \mathrm{C}$ & Semanal & $2250 \mathrm{~B}$ \\
pH & - & Semanal & $4500-\mathrm{H}^{+} \mathrm{B}$ \\
Alcalinidade Total & $\mathrm{mg} \mathrm{CaCO} / \mathrm{L}$ & Semanal & $2320 \mathrm{~B}$ \\
Nitrogênio Total de Kjeldahl & $\mathrm{mg} / \mathrm{L}$ & Semanal & $4500-\mathrm{N} \mathrm{B}$ \\
Nitrogênio Amoniacal & $\mathrm{mg} / \mathrm{L}$ & Semanal & $4500-\mathrm{NH}_{3} \mathrm{D}$ \\
Nitrito & $\mathrm{mg} / \mathrm{L}$ & Semanal & $4500-\mathrm{NO}_{2} \mathrm{~B}$ \\
Nitrato & $\mathrm{mg} / \mathrm{L}$ & Semanal & $4500-\mathrm{NO}_{3} \mathrm{~B}$ \\
DBO $_{5,20}$ 20 & $\mathrm{mg} / \mathrm{L}$ & Semanal & $5210 \mathrm{~B}$ \\
DQOO$_{\text {bruta }}$ & $\mathrm{mg} / \mathrm{L}$ & Semanal & $5220 \mathrm{D}$ \\
Sólidos Totais (Fixos e Voláteis) & $\mathrm{mg} / \mathrm{L}$ & Semanal & $2540 \mathrm{E}$ \\
Sólidos Suspensos (Fixos e Voláteis) & $\mathrm{mg} / \mathrm{L}$ & Semanal & $2540 \mathrm{E}$ \\
\hline
\end{tabular}

Tabela 4.6 - Rotina de ensaios para monitoramento da eficiência na seqüência II.

\begin{tabular}{l|c|c|c}
\hline \multicolumn{1}{c|}{ Parâmetros } & Unidades & Freqüências & $\begin{array}{c}\text { Procedimento } \\
\mathbf{n}^{\mathbf{0}} .\end{array}$ \\
\hline Temperatura & ${ }^{\circ} \mathrm{C}$ & Semanal & $2250 \mathrm{~B}$ \\
pH & - & Semanal & $4500-\mathrm{H}^{+} \mathrm{B}$ \\
Alcalinidade Total & $\mathrm{mg} \mathrm{CaCO} / \mathrm{L}$ & Semanal & $2320 \mathrm{~B}$ \\
Nitrogênio Total de Kjeldahl & $\mathrm{mg} / \mathrm{L}$ & Semanal & $4500-\mathrm{N} \mathrm{B}^{-}$ \\
Nitrogênio Amoniacal & $\mathrm{mg} / \mathrm{L}$ & Semanal & $4500-\mathrm{NH}_{3} \mathrm{D}$ \\
Nitrito & $\mathrm{mg} / \mathrm{L}$ & Semanal & $4500-\mathrm{NO}_{2} \mathrm{~B}$ \\
Nitrato & $\mathrm{mg} / \mathrm{L}$ & Semanal & $4500-\mathrm{NO}_{3} \mathrm{~B}$ \\
DQO & $\mathrm{mg} / \mathrm{L}$ & Semanal & $5220 \mathrm{D}$ \\
Sólidos Totais (Fixos e Voláteis) & $\mathrm{mg} / \mathrm{L}$ & Semanal & $2540 \mathrm{E}$ \\
Sólidos Suspensos (Fixos e Voláteis) & $\mathrm{mg} / \mathrm{L}$ & Semanal & $2540 \mathrm{E}$ \\
Carbono orgânico Total (COT) & $\mathrm{mg} / \mathrm{L}$ & Semanal & $5310 \mathrm{~B}$ \\
\hline
\end{tabular}

Tabela 4.7 - Rotina de ensaios para monitoramento da eficiência no Biofiltro Piloto.

\begin{tabular}{l|c|c|c}
\hline \multicolumn{1}{c|}{ Parâmetros } & Unidades & Freqüências & $\begin{array}{c}\text { Procedimento } \\
\mathbf{n}^{\mathbf{0}} .\end{array}$ \\
\hline Temperatura & ${ }^{\circ} \mathrm{C}$ & Semanal & $2250 \mathrm{~B}$ \\
pH & - & Semanal & $4500-\mathrm{H}^{+} \mathrm{B}$ \\
Alcalinidade Total & $\mathrm{mg} \mathrm{CaCO} / \mathrm{L}$ & Semanal & $2320 \mathrm{~B}$ \\
Nitrogênio Total de Kjeldahl & $\mathrm{mg} / \mathrm{L}$ & Semanal & $4500-\mathrm{N} \mathrm{B}$ \\
Nitrogênio Amoniacal & $\mathrm{mg} / \mathrm{L}$ & Semanal & $4500-\mathrm{NH}_{3} \mathrm{D}$ \\
Nitrito & $\mathrm{mg} / \mathrm{L}$ & Semanal & $4500-\mathrm{NO}_{2} \mathrm{~B}$ \\
Nitrato & $\mathrm{mg} / \mathrm{L}$ & Semanal & $4500-\mathrm{NO}_{3} \mathrm{~B}$ \\
DQO & $\mathrm{mg} / \mathrm{L}$ & Semanal & $5220 \mathrm{D}$ \\
Sólidos Totais (Fixos e Voláteis) & $\mathrm{mg} / \mathrm{L}$ & Semanal & $2540 \mathrm{E}$ \\
Sólidos Dissolvidos (Fixos e & $\mathrm{mg} / \mathrm{L}$ & Semanal & $2540 \mathrm{E}$ \\
Voláteis) & & & \\
\hline
\end{tabular}


Algumas observações devem ser feitas quanto a esses parâmetros e suas respectivas freqüências de análises. A DBO, por exemplo, não foi efetuada na seqüência II, pois o método empregado na análise dessa variável não era aplicável para valores muito pequenos como os encontrados no efluente pós-tratado da seqüência I. O mesmo ocorreu com a DQO que também não foi mensurada, em grande parte das seqüências I e II até ser possível empregar um outro método para leituras na faixa de 10 a $50 \mathrm{mg} / \mathrm{L}$. Na seqüência II, enquanto esse outro método para análise de DQO não foi adotado a estimativa da remoção da matéria orgânica total foi feita pelos valores de COT.

Como o objetivo principal da pesquisa foi remoção de nitrogênio do efluente do reator UASB uma atenção especial foi dada a todas as variáveis referentes a esse elemento ao longo de todas as fases de desenvolvimento do BF.

A análise de sólidos foi realizada esporadicamente nas seqüências I e II, pois a pesquisa estava concentrada em melhorar a desnitrificação no sistema. Essa análise foi efetuada regularmente, na fase de operação do Biofiltro Piloto para quantificação da produção de lodo.

\subsection{Dificuldades Encontradas}

Ao longo de toda fase experimental a pesquisa passou por problemas de origem externa que acarretaram em atraso no cronograma proposto no projeto de pesquisa inicial.

No início do monitoramento, a pesquisa ainda não possuía verba para aquisição de equipamentos essenciais para o funcionamento do sistema como bombas, rotâmetro, compressor de ar, e oxímetro. Até a chegada de tal verba o sistema operou com uma bomba dosadora, utilizada em outra pesquisa e que estava disponível. Essa bomba apresentava problemas para aferição da vazão. Isso por vezes acarretou em alta vazão afluente ao sistema, prejudicando o desempenho dos biofiltros devido ao aumento da carga orgânica volumétrica aplicada. Esse problema foi corrigido com a aquisição de bombas microprocessadas que conferiram perfeito controle das vazões afluentes ao sistema.

O compressor de ar que alimentava o reator aeróbio R1 na seqüência I quebrou, e a demora em sua substituição fez com o sistema tivesse a atividade nitrificante totalmente reduzida. Com isso, demorou certo tempo para que o sistema entrasse novamente em equilíbrio dinâmico aparente. $\mathrm{Na}$ operação do Biofiltro Piloto a 
alimentação de ar comprimido também foi prejudicada em duas ocasiões em que o compressor de ar também quebrou.

Uma carga tóxica, de origem desconhecida, proveniente da rede que alimentava o reator UASB, também afetou o sistema na seqüência I, de tal forma que este teve que ser novamente inoculado para que entrasse em equilíbrio dinâmico aparente o mais rápido possível.

Uma greve de funcionários da instituição, onde a pesquisa foi realizada contribuiu, também, para que os reatores ficassem por dois meses sem o devido monitoramento comprometendo a evolução da pesquisa.

A ETE, na qual a bancada experimental foi instalada, não possui funcionários para sua correta manutenção e operação. Por vezes, problemas nessa estação como: quebra da bomba de recalque que alimentava o reator UASB, por exemplo, resultava na parada da operação dos reatores que ficavam sem a devida alimentação.

O reator UASB, por vezes teve sua operação interrompida por obstrução de sua entrada por placas de gordura. Aliás, o reator UASB, durante a operação do Biofiltro Piloto, foi utilizado com objeto de pesquisa de outros pesquisadores e teve sua eficiência de tratamento totalmente comprometida. Isso acarretou em diversos transtornos na operação do BF como, por exemplo, obstrução da válvula com crivo da bomba que alimentava o sistema, devido a volume excessivo de sólidos carreados no efluente do reator UASB.

Logo, o sistema por diversas vezes teve sua operação interrompida resultando em atrasos na dinâmica da pesquisa em todas as fases. Os resultados que serão apresentados no próximo capítulo, refletem tais intercorrências. 


\section{Resultados e discussão}

Este capítulo será dedicado à apresentação e discussão dos resultados obtidos na operação dos reatores seqüenciais e do Biofiltro Piloto.

Os dados serão apresentados na forma de gráficos e tabelas na tentativa de melhor ilustrar o comportamento dos sistemas de reatores empregados no póstratamento do efluente do reator UASB.

Para as seqüências I e II o desempenho de cada um dos reatores será mostrado separadamente para visualização do papel que cada um deles desempenhava no póstratamento. Já para o Biofiltro Piloto somente serão apresentados os resultados de entrada e saída do sistema.

Nos reatores seqüenciais os dados de entrada foram denominados ER1 e ER2 e os de saída SR1, SR2 e SR3, respectivamente. Para o Biofiltro Piloto os resultados das amostras coletadas na entrada do sistema foram denominados ER2 e os de saída SR3.

A eficiência total dos reatores seqüenciais e do Biofiltro Piloto, em relação à remoção ou conversão de DQO, nitrogênio e demais variáveis utilizadas no monitoramento, foi calculada considerando dados de entrada e de saída, respectivamente. Assim, a eficiência total nas seqüências I e II foi calculada com os dados de entrada, ER1 e ER2, e os da saída SR3.

As eficiências de cada reator utilizado em todas as fases da pesquisa foram calculadas a partir dos dados de entrada e saída de cada um deles.

No sistema definitivo essa eficiência total do sistema foi calculada com os dados de ER2 e SR3, respectivamente. 


\subsection{Seqüência I}

\subsubsection{Remoção de $\mathrm{DBO}_{5,20}$ e DQO}

Na tabela 5.1 estão apresentados os valores mínimos, máximos, número de dados analisados e média aritmética dos resultados obtidos, para o parâmetro $\mathrm{DBO}_{5,20}$, durante o período de operação referente a seqüência I, e respectivas eficiências de remoção.

Tabela 5.1 - Valores mínimos, máximo, média aritmética e eficiência de remoção de $\mathrm{DBO}_{5,20}$ para os resultados obtidos na seqüência I.

\begin{tabular}{c|cccc}
\hline $\begin{array}{c}\text { DBO } \\
\text { (m,20 }\end{array}$ & Afluente & \multicolumn{3}{c}{ Efluente } \\
\cline { 3 - 5 } & ER1 & SR1 & SR2 & SR3 \\
\hline Média & 79 & 14 & 6 & 4 \\
Mínimo & 32 & 5 & ND & ND \\
Máximo & 160 & 36 & 20 & 10 \\
n & 11 & 11 & 11 & 11 \\
\hline DBO $_{5,20}$ & & Eficiência de remoção (\%) & \\
& SR1 & SR2 & SR3 & Total* \\
\hline Média & 77 & 67 & 49 & 95 \\
Mínimo & 31 & 37 & 12 & 82 \\
Máximo & 95 & 87 & 74 & 100 \\
n & 11 & 10 & 8 & 11 \\
\hline
\end{tabular}

(*) Valor calculado tomando os valores de ER1 e SR3, equivalente à eficiência geral do sistema de reatores.

No cálculo da eficiência dos reatores, o sistema revelou valores negativos para R2 e R3. Isso pode ter ocorrido pela própria diferença de sólidos desprendidos do suporte durante a coleta das amostras. Sendo assim, esses dados foram descartados.

Como o método utilizado para $\mathrm{DBO}_{5,20}$ oferecia precisão para leitura de valores até $1 \mathrm{mg} / \mathrm{L}$, valores abaixo desse limite foram considerados não detectados (ND). 
Os dados da tabela 5.1 revelam que a eficiência geral de remoção de $\mathrm{DBO}_{5,20}$ no sistema, variou entre 82,0 a $100 \%$ para valor médio de $95 \%$. As concentrações médias de $\mathrm{DBO}_{5,20}$, de entrada e saída do sistema foram, respectivamente, 79 e $4 \mathrm{mg} / \mathrm{L}$.

Os dados dessa tabela mostram, também, que os reatores funcionaram de forma seqüenciada na qual um complementou o desempenho do outro. Isso foi observado pelos valores médios da $\mathrm{DBO}_{5,20}$ iguais a 14,6 e $4 \mathrm{mg} / \mathrm{L}$ para os reatores $\mathrm{R} 1$, R2 e R3, respectivamente, conforme proposta do sistema.

Para melhor interpretação estatísticas dos dados da tabela 5.1 um gráfico tipo box-plot foi elaborado contendo os valores máximo, mínimo, primeiro, segundo e terceiro quartis denominados, respectivamente, Q1, Q2 e Q3, e eficiência total de remoção do sistema. Na figura 5.1 está apresentado esse gráfico.

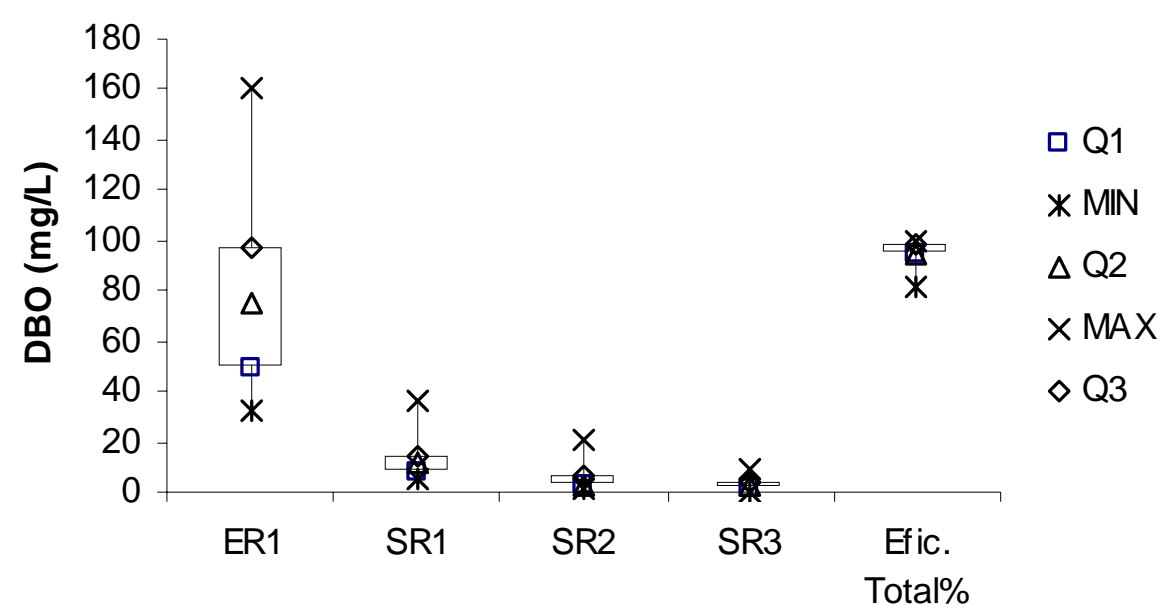

Amostras

Figura 5.1 - Box-plot dos dados relativos aos resultados da $\mathrm{DBO}_{5,20}$.

Pela figura 5.1 é possível observar que $50 \%$ dos resultados de $\mathrm{DBO}_{5,20}$ afluente ao BASSE estiveram entre 49 e $97 \mathrm{mg} / \mathrm{L} ; 25 \%$ abaixo de $49 \mathrm{mg} / \mathrm{L}$ e 25\% acima de 97 $\mathrm{mg} / \mathrm{L}$. Em SR1, 50\% dos resultados referentes à $\mathrm{DBO}_{5,20}$ estiveram entre 8 e $14 \mathrm{mg}$ $\mathrm{O}_{2} / \mathrm{L}$ de $\mathrm{DBO} 5,20$.

Os dados de SR3 mostraram que 50\% dos resultados estiveram entre 2 e $4 \mathrm{mg} / \mathrm{L}$; $25 \%$ acima de $4 \mathrm{mg} / \mathrm{L}$ para valor máximo de $9,0 \mathrm{mg} / \mathrm{L}$ e $25 \%$ abaixo de 2 para valor mínimo de $1 \mathrm{mg} / \mathrm{L}$. 
A eficiência total do sistema esteve entre 94 e $97 \%$ em $50 \%$ das amostras analisadas, sendo a maior parte da carga orgânica carbonácea era removida em R1, como projetado (figura 5.1).

As figuras 5.2 e 5.3 mostram, respectivamente a dispersão dos resultados da $\mathrm{DBO}_{5,20}$ e da eficiência de remoção total do sistema de reatores, durante o período de operação da seqüência I.

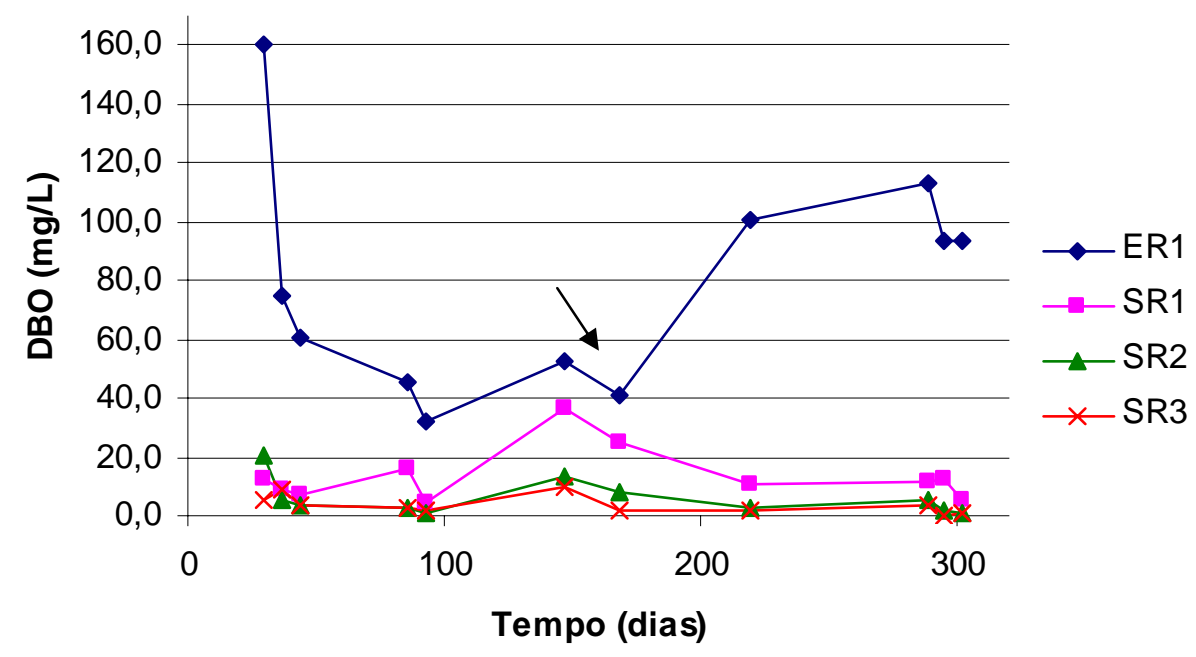

Figura 5.2 - $\mathrm{DBO}_{5,20}$ de entrada e saída do sistema de reatores operados na seqüência I

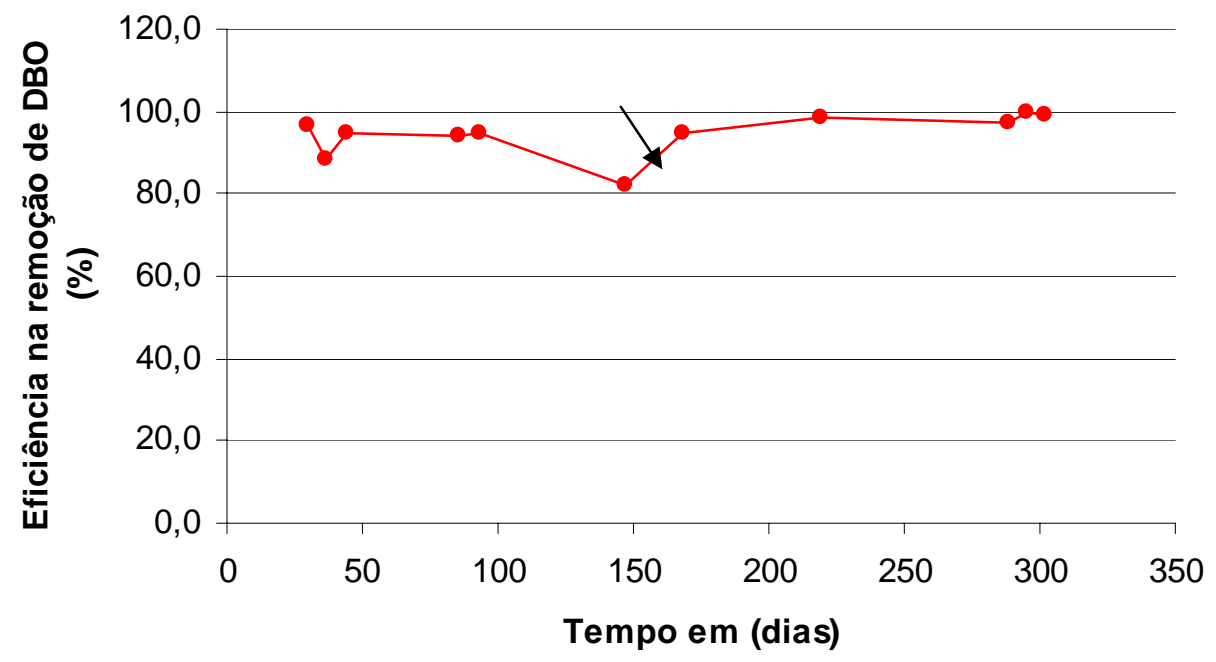

Figura 5.3 - Eficiência total de remoção de $\mathrm{DBO}_{5,20}$ durante o período de operação da seqüência I.

Na figura 5.2 é possível observar um pico nas concentrações em todos os pontos de saída, indicado pela seta, revelando queda na eficiência do sistema. Essa queda foi observada no $150^{\circ}$ dia de operação, conforme indicado na figura 5.3. Esses resultados 
foram obtidos alguns dias após o colapso do sistema, ocorrido em virtude do lançamento de uma carga tóxica na rede de coleta de esgoto que alimentava o reator UASB.

Como já mencionado anteriormente, o sistema foi novamente inoculado nesse período para rápida partida e retorno às condições de operação predominantes antes de tal acidente.

$\mathrm{Na}$ figura 5.3 foi possível observar que o sistema estava em recuperação com eficiência de remoção igual a 82 \%. Essa eficiência foi a menor registrada ao longo do período de investigações da seqüência I. Apesar, disso o sistema revelou alta taxa de remoção da matéria orgânica em $\mathrm{DBO}_{5,20}$. Ao final do período de avaliação dessa seqüência, o procedimento analítico empregado para quantificação da $\mathrm{DBO}_{5,20}$ não era adequado em virtude dos baixos valores encontrados no efluente do reator R3.

Na tabela 5.2 estão apresentados os valores mínimos, máximos, média aritmética e número de amostras analisadas das cargas orgânicas volumétricas aplicada $\left(\mathrm{COV}_{\mathrm{a}}\right)$ e removida $\left(\mathrm{COV}_{\mathrm{r}}\right)$ em termos de $\mathrm{DBO}_{5,20}$ do sistema, monitoradas nesse período.

Tabela 5.2 - Valores mínimos, máximos, média aritmética e número de amostras analisadas das cargas orgânicas volumétricas aplicada $\left(\mathrm{COV}_{\mathrm{a}}\right)$ e removida $\left(\mathrm{COV}_{\mathrm{r}}\right)$ do sistema de reatores operados na seqüência I.

\begin{tabular}{|c|c|c|c|c|}
\hline \multirow{2}{*}{$\begin{array}{c}\mathrm{COV}_{\mathrm{a}}(\mathrm{kg} \\
\mathrm{de} \\
\left.\mathrm{DBO} / \mathrm{m}^{3} \mathrm{~d}\right)\end{array}$} & \multicolumn{4}{|c|}{ Aplicada } \\
\hline & SR1 & \multicolumn{2}{|c|}{ SR2 } & SR3 \\
\hline Média & 0,47 & \multicolumn{2}{|c|}{0,041} & 0,048 \\
\hline Mínimo & 0,19 & \multicolumn{2}{|c|}{0,014} & 0,009 \\
\hline Máximo & 0,96 & \multicolumn{2}{|c|}{0,109} & 0,162 \\
\hline $\mathbf{n}$ & 11 & \multicolumn{2}{|c|}{11} & 11 \\
\hline $\mathrm{COV}_{\mathrm{r}}(\mathrm{kg}$ & \multicolumn{4}{|c|}{ Removida } \\
\hline $\begin{array}{c}\text { de } \\
\left.\text { DBO } / \mathrm{m}^{3} \mathrm{~d}\right)\end{array}$ & SR1 & SR2 & SR3 & Total* \\
\hline Média & 0,43 & 0,011 & 0,030 & 0,445 \\
\hline Mínimo & 0,17 & 0,0004 & 0,003 & 0,181 \\
\hline Máximo & 0,93 & 0,025 & 0,118 & 0,918 \\
\hline $\mathbf{n}$ & 11 & 7 & 8 & 11 \\
\hline
\end{tabular}

Como pode ser observado pelos dados da tabela 5.2, a maior parte da carga orgânica volumétrica aplicada ao sistema em R1 era removida no próprio reator. Para 
carga média de $0,47 \mathrm{~kg}$ de $\mathrm{DBO} / \mathrm{m}^{3} \mathrm{~d}$ era removido em média $0,43 \mathrm{~kg}$ de $\mathrm{DBO} / \mathrm{m}^{3} \mathrm{~d}$. Isso ocorreu conforme esperado uma vez que a função de R1 era remover grande parte da carga afluente ao sistema e assim oferecer condições para nitrificação no reator R2. Segundo CAMPOS (1989) altas cargas orgânicas volumétricas aplicadas ao sistema podem inibir o metabolismo dos microrganismos nitrificantes.

Essa inibição pode ocorrer pela competição de espaço no biofilme, pois as bactérias heterótrofas, responsáveis pelo consumo de matéria orgânica carbonácea, possuem taxa de crescimento maior que as bactérias autótrofas, responsáveis pela nitrificação.

O objetivo de R1 na seqüência I era produzir um efluente parcialmente nitrificado, com concentração de oxigênio dissolvido suficiente para conclur a nitrificação em R2 e com baixa carga orgânica para não inibir os microrganismos nitrificantes. Como pode ser visto pelos dados da tabela 5.2, no tocante à remoção da carga aplicada ao R2 isso ocorreu, pois esse reator recebeu em média 0,041 kg de $\mathrm{DBO} / \mathrm{m}^{3} \mathrm{~d}$.

Os dados da tabela 5.2 também revelam que R1 teve o papel de atenuar eventuais sobrecargas orgânicas. Isso pode ser observado pelo valor máximo de $\mathrm{COV}_{\mathrm{a}}$ em R1 que foi de $0,96 \mathrm{~kg}$ de $\mathrm{DBO} / \mathrm{m}^{3} \mathrm{~d}$ sendo removido $0,93 \mathrm{~kg}$ de $\mathrm{DBO} / \mathrm{m}^{3} \mathrm{~d}$. O fato de R1 atenuar essa sobrecarga garantiu que a nitrificação não fosse inibida em R2.

A correlação estabelecida entre as cargas orgânicas volumétricas aplicadas e removidas no sistema que pode se vista na figura 5.4.

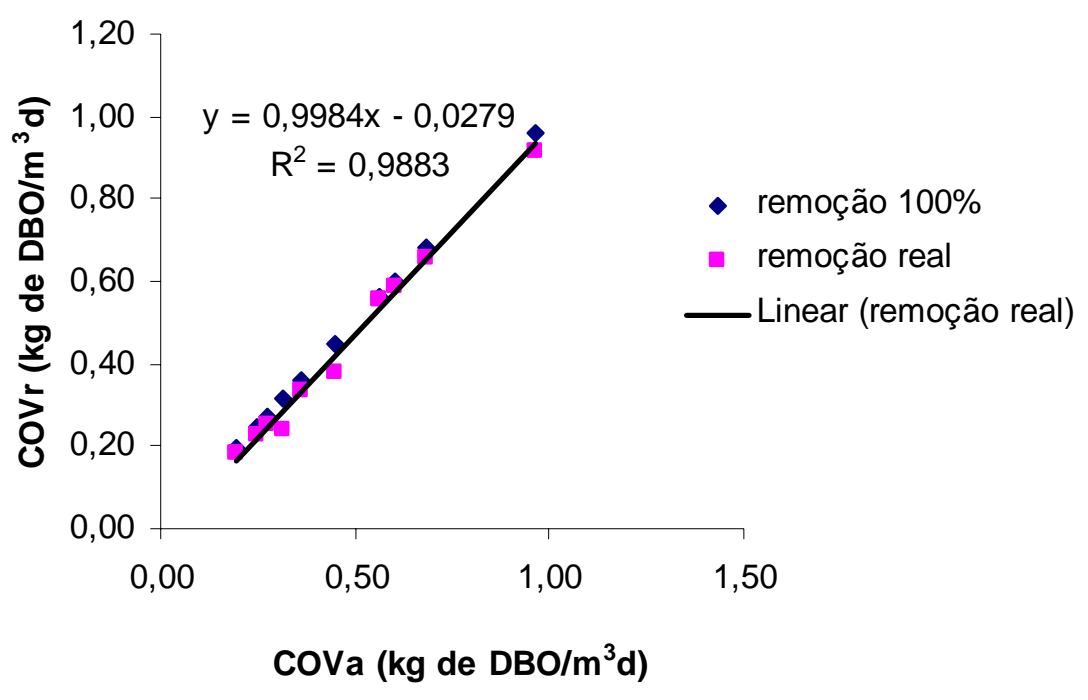

Figura 5.4 - Correlação entre as cargas orgânicas volumétricas aplicadas removidas. 
A figura 5.4 ilustra pontos de remoção ideal (100\%), onde toda carga aplicada seria removida, e pontos de remoção real relacionando a carga aplicada com a removida. A figura apresenta também, a equação da reta ajustada aos pontos de remoção real. Essa equação revela que a taxa de remoção de carga orgânica aplicada em DBO foi de $0,998 \mathrm{~kg}$ de $\mathrm{DBO}$ removida/ $\mathrm{kg}$ de DBO aplicada, revelando alto desempenho do sistema na remoção da carga orgânica carbonácea, em $\mathrm{DBO}_{5,20}$, proveniente do reator UASB.

A tabela 5.3 apresenta os valores mínimos, máximos, média aritmética e número de dados analisados para DQO durante o período de operação referente à seqüência I, bem como as respectivas eficiências de remoção dessa variável.

Tabela 5.3 - Valores mínimos, máximo, média artimética e eficiência de remoção de DQO para amostras coletadas na seqüência I.

\begin{tabular}{c|cccc}
\hline DQO & Afluente & \multicolumn{3}{c}{ Efluente } \\
\cline { 3 - 5 }$(\mathbf{m g} / \mathbf{L})$ & ER1 & SR1 & SR2 & SR3 \\
\hline Média & 98,0 & 57,0 & 43,0 & 28,0 \\
Mínimo & 30,0 & 22,0 & 14,0 & 8,0 \\
Máximo & 217,0 & 110,0 & 118,0 & 75,0 \\
n & 24 & 24 & 24 & 24 \\
\hline DQO & & Eficiência de remoção (\%) & \\
(mg/L) & SR1 & SR2 & SR3 & Total* \\
\hline Média & 48,0 & 42,0 & 41,0 & 68,0 \\
Mínimo & 10,0 & 4,0 & 12,0 & 16,0 \\
Máximo & 85,0 & 66,0 & 88,0 & 94,0 \\
n & 19 & 20 & 17 & 24 \\
\hline
\end{tabular}

(*) Valor calculado tomando os valores de ER1 e SR3, equivalente à eficiência total do sistema de reatores.

Os dados da tabela 5.3 revelam que para a concentração média de DQO afluente ao sistema de reatores igual a $98,0 \mathrm{mg} / \mathrm{L}$, as concentrações médias em DQO dos efluentes dos reatores R1, R2, e R3 foram, respectivamente, 57,0, 43,0, e 28,0 mg/L., o que equivale a eficiências variando de 68,0 a 94,0\%. Na figura 5.5 está representado um gráfico tipo box-plot para melhor visualização da dispersão dos dados contidos na tabela 5.3. 


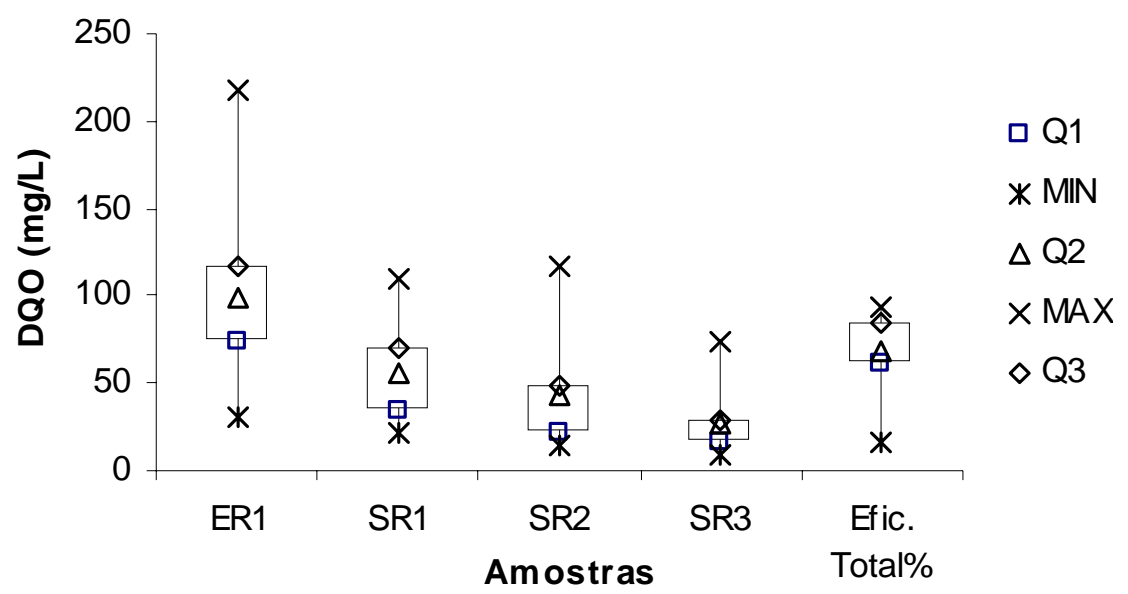

Figura 5.5 - Box-plot dos dados relativos aos resultados da DQO.

A figura 5.5 revela que a DQO de $50 \%$ dos dados de entrada do sistema variou entre 73 e 116 mg/L. Já os dados de saída de R3 variaram entre 16 e 30 mg/L em 50\% dos dados analisados. A eficiência de remoção de DQO no sistema de reatores foi maior que $84 \%$ para $75 \%$ das amostras investigadas. Isso mostra que o sistema operou com alta eficiência de remoção desse parâmetro na maior parte do período de investigações da seqüência I.

Para 25\% das amostras a eficiência total de remoção de DQO esteve entre 16 e $84 \%$. Os resultados que estiveram nessa faixa de variação podem ter sido influenciados pela fração não biodegradável da matéria orgânica efluente do reator UASB.

A relação $\mathrm{DBO} / \mathrm{DQO}$ oferece uma estimativa da porcentagem da matéria orgânica biodegradável. A tabela 5.4 mostra os valores mínimo, máximo, média aritmética e número de amostras analisadas para a relação DBO/DQO.

Tabela 5.4 Valores mínimo, máximo, média aritmética e número de amostras analisadas para a relação $\mathrm{DBO} / \mathrm{DQO}$ durante operação da seqüência I.

\begin{tabular}{c|cccc}
\hline DBO/DQO & Afluente & \multicolumn{3}{c}{ Efluente } \\
\cline { 3 - 5 } & ER1 & SR1 & SR2 & SR3 \\
\hline Média & 0,87 & 0,31 & 0,19 & 0,16 \\
Mínimo & 0,34 & 0,10 & 0,04 & 0,03 \\
Máximo & 1 & 0,55 & 0,56 & 0,44 \\
$\mathbf{n}$ & 11 & 11 & 11 & 11 \\
\hline
\end{tabular}


Os dados da tabela 5.4 mostram que, em média, $87 \%$ da matéria orgânica, em DQO, afluente ao sistema de reatores, era biodegradável. Na saída do sistema a matéria orgânica biodegradáel foi de 16\% revelando que a maior parte da matéria orgânica afluente havia sido estabilizada.

A questão da ausência de lavagem dos leitos filtrantes dos reatores pode ter comprometido a eficiência de remoção de DQO do sistema. Isso pode ter aumentado o valor da DQO de saída dos biofiltros, em virtude do arraste da biomassa estabilizada (não biodegradável) para fora dos reatores. RODRÍGUEZ (2006), operando filtro biológico aeróbio/anóxico, empregado no pós-tratamento de efluente de reator UASB, atribuiu a baixa eficiência de remoção de DQO, observada em sua pesquisa, ao arraste de lodo acumulado para fora do sistema. Como o sistema era utilizado para póstratamento do efluente do reator UASB era esperado que parte da matéria orgânica afluente aos reatores não fosse facilmente biodegradável. Essa afirmação é corroborada pelos valores médios da relação DBO/DQO de saída do sistema iguais a 0.31, 0.19 e 0.16, para os reatores, R1, R2 e R3, respectivamente, revelando a biodegradabilidade do efluente desses reatores.

O comportamento dos resultados da DQO durante o período correspondente à seqüência I está representado na figura 5.6.

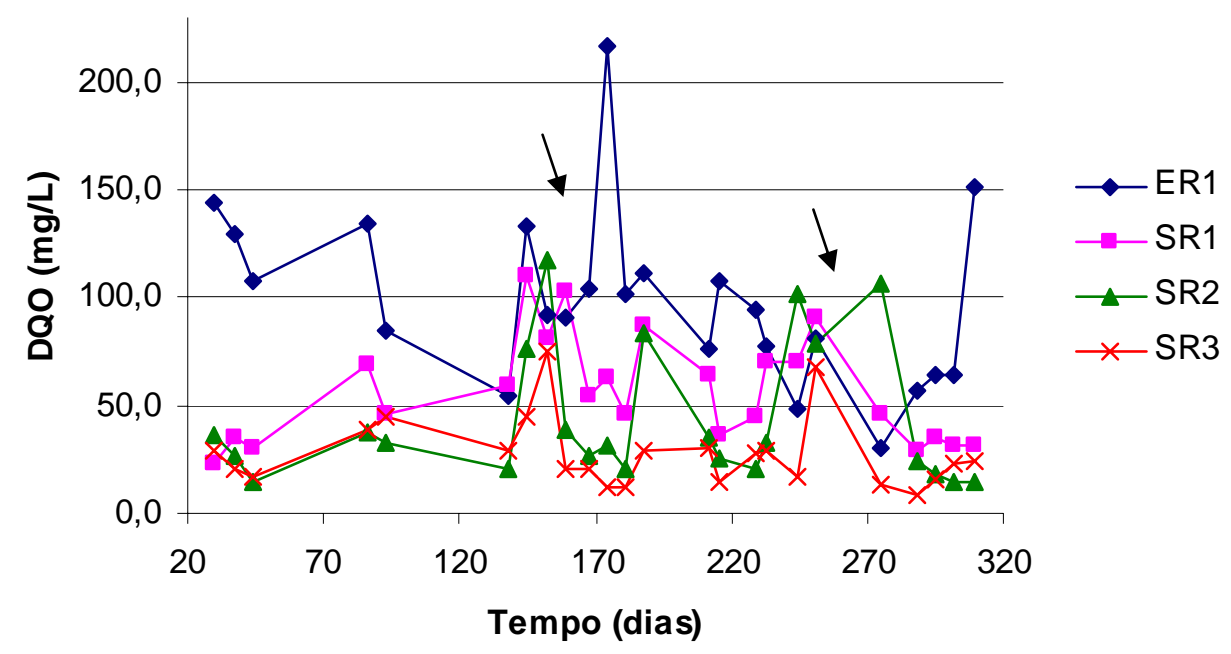

Figura 5.6 - Variação da DQO afluente e efluente do sistema durante o período de operação correspondente a seqüência I. 
A carga tóxica, mencionada anteriormente, pode ter comprometido os resultados de DQO no mesmo período observado para $\mathrm{DBO}_{5,20}$ como é possível constatar na figura 5.6. Pode ser observado que aproximadamente no $150^{\circ}$ dia de operação da seqüência $I$, para DQO afluente igual a $92 \mathrm{mg} / \mathrm{L}$, a DQO efluente dos reatores R1, R2 e R3 foi, respectivamente, igual a 81,118 , e $75 \mathrm{mg} / \mathrm{L}$.

$\mathrm{O} 174^{\circ}$ dia de operação revela que o sistema suportou bem à maior concentração de DQO afluente que foi igual a $217 \mathrm{mg} / \mathrm{L}$, resultando em concentrações efluentes iguais a 63, 32 e $13 \mathrm{mg} / \mathrm{L}$ para os reatores R1, R2 e R3, respectivamente, sendo que a eficiência total de remoção do sistema foi de $94 \%$.

No $250^{\circ}$ dia de operação a DQO afluente ao sistema de reatores foi de $81 \mathrm{mg} / \mathrm{L} \mathrm{e}$ as concentrações efluentes de R1, R2 e R3, foram, respectivamente, 90, 79,0 e 68 mg/L. Tais resultados podem ser atribuídos, também, ao arraste de sólidos do sistema.

\subsubsection{Remoção de Nitrogênio}

A seqüência I foi empregada no inicio da operação dos reatores seqüenciais e foi mantida até o $329^{\circ}$ dia, no qual o sistema foi adaptado para operar conforme seqüência II, pelos motivos apontados anteriormente.

O limite de quantificação dos métodos empregados para análise dos parâmetros nitrogênio total Kjedahl (NTK) e nitrogênio amoniacal $\left(\mathrm{N}-\mathrm{NH}_{3}\right)$, em toda pesquisa, possuíam sensibilidade mínima de leitura para valores até $0,1 \mathrm{mg} / \mathrm{L}$. Assim, para resultados abaixo desse valor, foi considerado não detectada (ND) a concentração desses parâmetros nas amostras investigadas.

Os dados referentes à conversão de NTK foram organizados na tabela 5.5, que ilustra os valores mínimo, máximo e média aritmética detectados nas amostras analisadas na seqüência I. Essa tabela mostra, também, o número de amostras cujo valor da concentração de NTK não foi detectada, ou seja, resultaram em valores menores que $0,1 \mathrm{mg} / \mathrm{L}$. 
Tabela 5.5 - Valores mínimo, máximo, média aritmética e eficiência total do sistema em relação a NTK para amostras analisadas, na seqüência I, e número de amostras com concentração não detectada.

\begin{tabular}{|c|c|c|c|c|c|}
\hline \multirow[t]{2}{*}{$\begin{array}{c}\text { NTK } \\
\text { (Seqüência I) }\end{array}$} & \multirow{2}{*}{$\begin{array}{c}\text { Afluente } \\
\text { (mg/L) } \\
\text { ER1 }\end{array}$} & \multicolumn{3}{|c|}{$\begin{array}{c}\text { Efluente } \\
\text { (mg/L) }\end{array}$} & \multirow{2}{*}{$\begin{array}{c}\text { Efic. } \\
\text { Total } \\
(\%)\end{array}$} \\
\hline & & SR1 & SR2 & SR3 & \\
\hline Média & 40,9 & 7,5 & 5,3 & 4,6 & 87,7 \\
\hline Mínimo & 21,3 & $N D$ & $N D$ & $N D$ & 5,2 \\
\hline Máximo & 103,5 & 37,9 & 37,1 & 34,5 & 100,0 \\
\hline $\mathbf{n}$ & 27 & 27 & 27 & 27 & 27 \\
\hline $\begin{array}{c}\text { Valores }<0,1 \\
\text { mg/L }\end{array}$ & 0 & 7 & 10 & 16 & - \\
\hline
\end{tabular}

Segundo os dados apresentados na tabela 5.5, para concentração média em NTK afluente ao sistema de reatores igual a $40,9 \mathrm{mg} / \mathrm{L}$, as concentrações médias efluentes do sistema foram 7,5; 5,3 e 4,6 mg/L para os reatores R1, R2 e R3, respectivamente. Assim, é possível concluir que a maior parte do nitrogênio total, NTK, era convertido em R1, ficando os demais reatores com o papel de complementar tal conversão.

Esse fato pode ser corroborado pelos pontos amostrais de cada reator que revelaram concentrações efluentes de NTK inferiores a 0,1 mg/L. Das 27 amostras analisadas para o efluente de cada reator, as que resultaram em concentração menor que 0,1 mg NTK/L, foram 7, 10 e 16 para os reatores R1, R2 e R3, respectivamente.

Os dados da seqüência I também revelaram o impacto que a carga tóxica, mencionada anteriormente, trouxe ao sistema prejudicando o desempenho de todos os reatores na conversão de NTK. Isso é notado pelos valores das concentrações máximas efluentes de cada reator iguais a 37,9; 37,1 e 34,5 mg/L para os reatores R1, R2 e R3, respectivamente. Essa afirmação é confirmada pela variação das concentrações de NTK durante a operação dos reatores dessa seqüência apresentada na figura 5.7. 


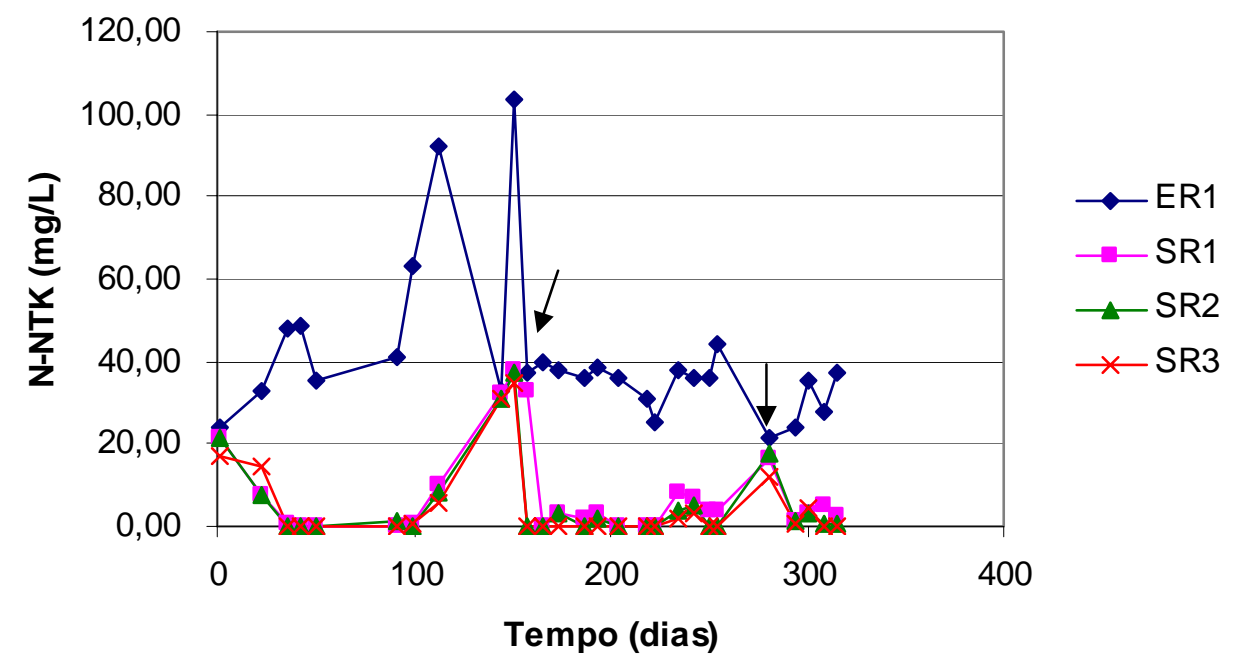

Figura 5.7 - Variação das concentrações de NTK durante a operação da seqüência I.

No $144^{\circ}$ dia de operação, como indica a seta, a concentração em NTK afluente ao sistema de reatores foi igual a $32,8 \mathrm{mg} / \mathrm{L}$, e a concentração efluente de cada um dos reatores foi 32,0; 31,1 e 31,1 mg/L para os reatores R1, R2 e R3, respectivamente. Esse dado mostra a inatividade no sistema na conversão de NTK no período considerado.

No $151^{\circ}$ de operação, o impacto causado pela carga tóxica já estava sendo atenuado uma vez que, para concentração de NTK no afluente ao sistema de reatores igual a $103,5 \mathrm{mg} / \mathrm{L}$, as concentrações efluentes foram 37,9; 37,0 e 34,5 para os reatores R1, R2 e R3 respectivamente. Após esse período, o sistema revelou alta taxa de conversão de NTK como observado na figura 5.7.

No $281^{\circ}$ dia operação, a seta indica outra queda na eficiência do sistema na conversão de NTK. Alguns dias antes, o R1 teve a injeção de ar comprimido interrompida devido à quebra do compressor de ar utilizado para tal fim. Logo, no dia da coleta os resultados revelaram que o sistema estava em recuperação no qual a concentração de NTK afluente foi de $21,3 \mathrm{mg} / \mathrm{L}$ e as concentrações efluentes dos reatores R1, R2 e R3 foram, respectivamente, 16,6; 17,5 e 11,8 mg/L.

A variabilidade estatística dos resultados de NTK está representada na figura 5.8 na forma de gráfico tipo box-plot das amostras analisadas na seqüência I. 


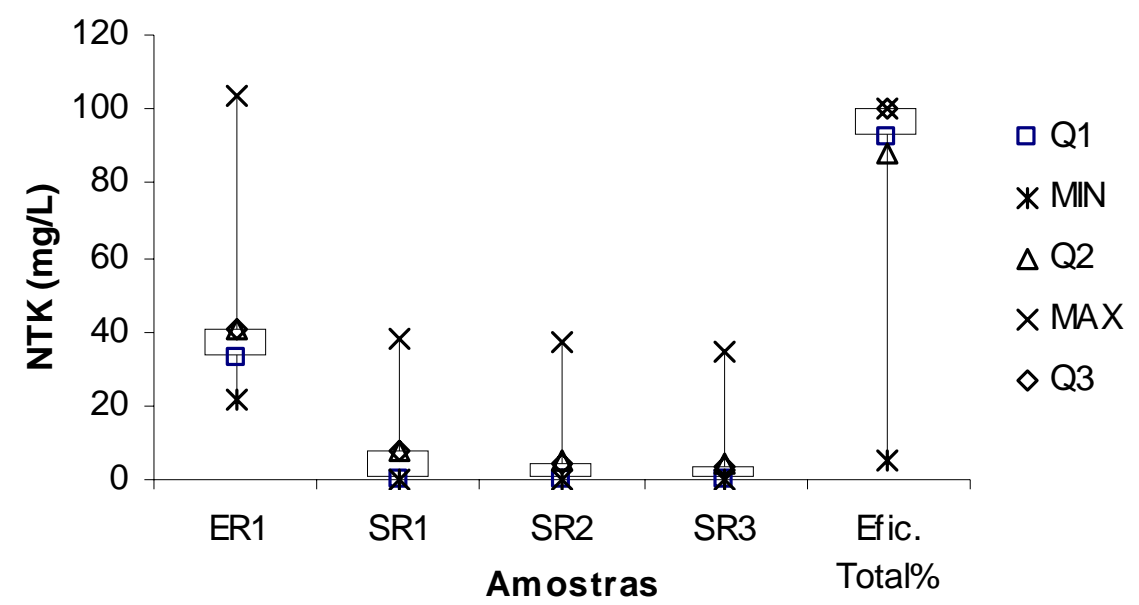

Figura 5.8 - Box-plot dos dados relativos aos resultados de NTK para a seqüência I.

Pode-se observar pela figura 5.8 que em 75\% das amostras analisadas, a eficiência total de conversão de NTK esteve entre 92,6 e 100\% . O sistema de reatores seqüências utilizados nessa fase revelou, portanto, alto potencial na conversão de NTK.

Pela figura 5.8 também é possível observar que a variação da concentração de NTK no afluente esteve entre 21 e $40 \mathrm{mg} / \mathrm{L}$ para $75 \%$ das amostras. As variações da concentração no efluente estiveram entre não detectado (ND) e 8, ND e 5 e ND e 4 para os reatores R1, R2 e R3, respectivamente, em 75\% dos resultados obtidos.

A tabela 5.6 apresenta os resultados obtidos em valores mínimo, máximo e media aritmética para amostras analisadas na seqüência I, para o parâmetro $\mathrm{N}-\mathrm{NH}_{3}$. Essa tabela mostra, ainda, o número de amostras em que concentração de $\mathrm{N}^{-\mathrm{NH}_{3}}$ não foi detectada.

Tabela 5.6 - Valores médio, mínimo e máximo de $\mathrm{N}_{-}-\mathrm{NH}_{3}$ as amostras analisadas, na seqüência I, e número de amostras com concentração não detectada.

\begin{tabular}{|c|c|c|c|c|c|}
\hline \multirow[t]{2}{*}{$\begin{array}{c}\mathrm{N}-\mathrm{NH}_{3} \\
\text { (Seqüência I) }\end{array}$} & \multirow{2}{*}{$\begin{array}{c}\text { Afluente } \\
\text { (mg/L) } \\
\text { ER1 }\end{array}$} & \multicolumn{3}{|c|}{$\begin{array}{c}\text { Efluente } \\
\text { (mg/L) }\end{array}$} & \multirow{2}{*}{$\begin{array}{c}\text { Efic. } \\
\text { Total } \\
(\%)\end{array}$} \\
\hline & & SR1 & SR2 & SR3 & \\
\hline Média & 32,6 & 5,0 & 3,9 & 3,7 & 87,3 \\
\hline Mínimo & 17,7 & $N D$ & $N D$ & $N D$ & 0,0 \\
\hline Máximo & 48,8 & 34,4 & 33,3 & 33,3 & 100,0 \\
\hline $\mathbf{n}$ & 27 & 27 & 27 & 27 & 27 \\
\hline $\begin{array}{c}\text { Valores }<\mathbf{0 , 1} \\
\mathbf{m g} / \mathbf{L}\end{array}$ & & 16 & 20 & 21 & - \\
\hline
\end{tabular}


$\mathrm{Na}$ seqüência I os dados da tabela 5.6 mostram que para concentração média afluente de $\mathrm{N}-\mathrm{NH}_{3}$ igual a 32,6 mg/L a concentração média efluente dos reatores $\mathrm{R} 1, \mathrm{R} 2$ e R3 foram, respectivamente, 5,0; 3,9 e 3,7 mg/L.

$\mathrm{O}$ valor médio desses dados foi influenciado pelas intercorrências, apontadas anteriormente, que prejudicaram a eficiência do sistema. Pode ser notado que para as 27 amostras analisadas em cada um dos reatores, 16, 20 e 21, respectivas aos R1, R2 e R3, resultaram em valores com concentrações de $\mathrm{N}-\mathrm{NH}_{3}$ menores que $0,1 \mathrm{mg} / \mathrm{L}$. Isso revela elevado potencial de conversão de $\mathrm{N}-\mathrm{NH}_{3}$ no conjunto de reatores da seqüência I.

Para melhor visualização da variabilidade estatística dos resultados obtidos para esse parâmetro foi elaborado o gráfico box-plot mostrado na figura 5.9.

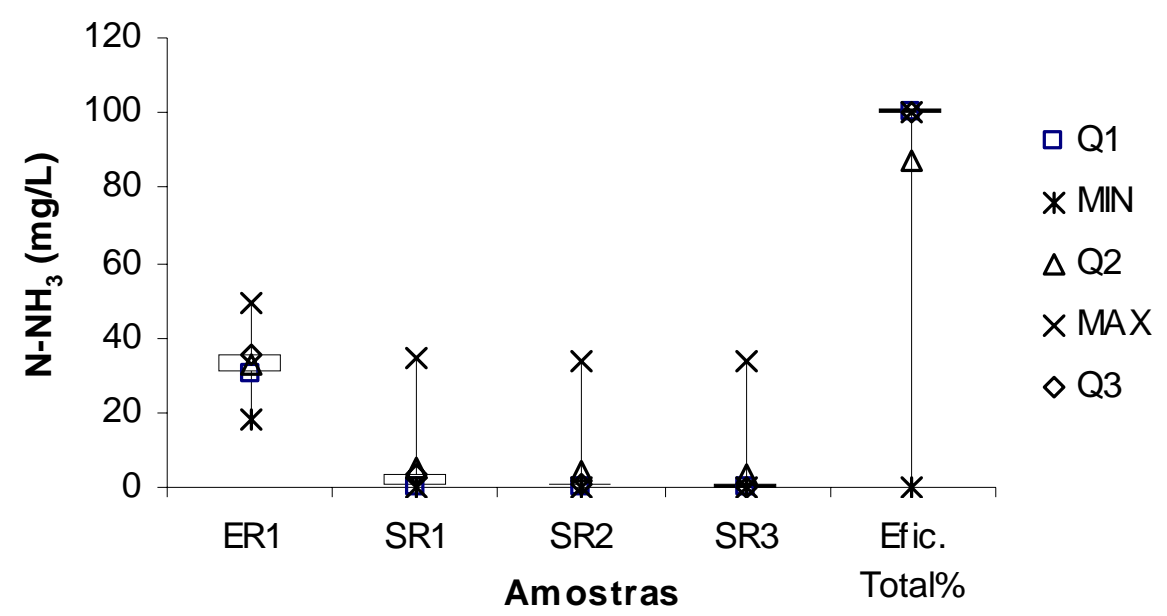

Figura 5.9 - Box-plot dos dados relativos aos resultados de N-NH 3 para a seqüência I.

Pela figura 5.9 é possível notar que a eficiência do sistema de reatores na remoção de $\mathrm{N}^{-\mathrm{NH}_{3}}$ foi praticamente $100 \%$ para quase todas as amostras analisadas. É possível observar, também, o desvio no valor médio (Q2) pelos motivos explicados anteriormente.

As concentrações no afluente variaram entre 30 e $50 \mathrm{mg} / \mathrm{L}$ para $75 \%$ dos resultados obtidos. Os dados de saída estiveram próximos ao valor limite de quantificação para a mesma percentagem de resultados.

A relação entre as cargas volumétricas aplicadas $(\mathrm{CVa})$ e removidas $(\mathrm{CVr})$ em $\mathrm{N}-\mathrm{NH}_{3}$ foi estabelecida como é possível observar na figura 5.10 na qual está apresentada a equação da reta ajustada aos pontos do gráfico.

A alta eficiência do sistema na remoção de $\mathrm{N}^{-\mathrm{NH}_{3}}$ é confirmada pela proximidade das retas de remoções real e ideal. 
A equação da figura 5.10 mostra que o sistema foi capaz de remover aproximadamente $1 \mathrm{~kg}$ de N-NH$/ 3 / \mathrm{m}^{3} \mathrm{~d}$ para cada $1 \mathrm{~kg}$ de N-NH$H_{3}$ aplicada $/ \mathrm{m}^{3} \mathrm{~d}$.

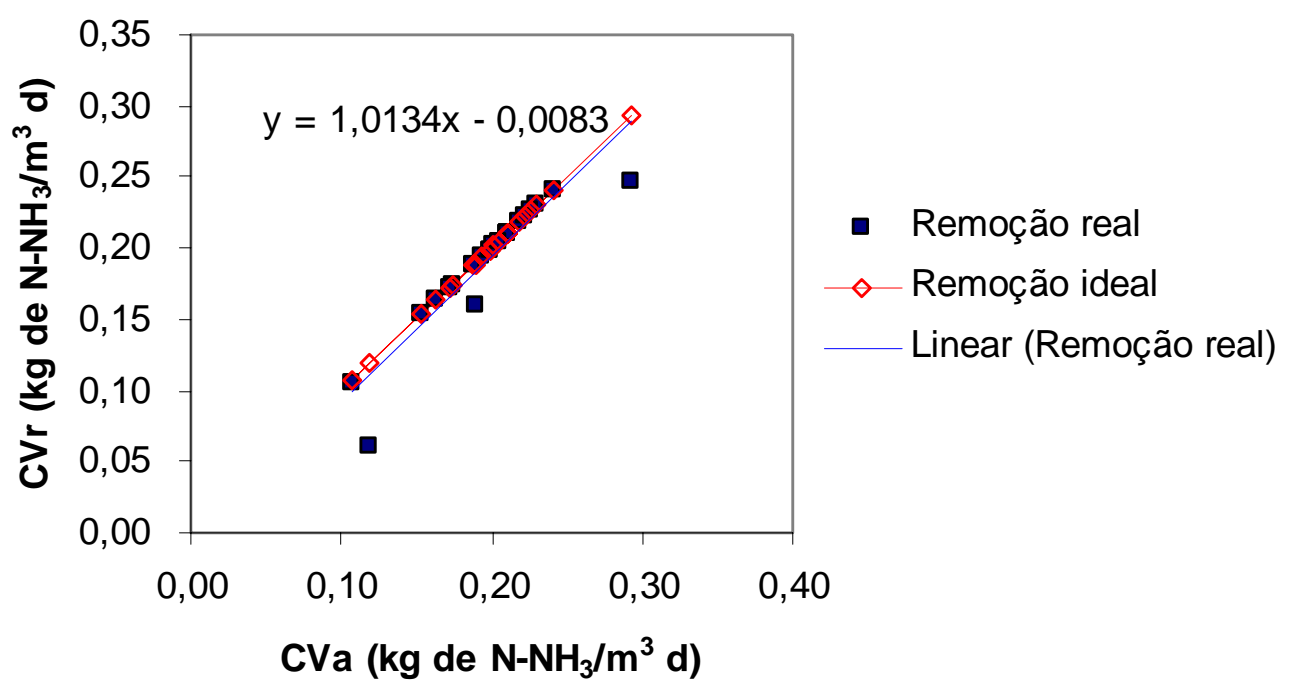

Figura 5.10 - Relação entre as cargas volumétricas aplicadas e removidas em N$\mathrm{NH}_{3}$ na seqüência I.

A variação das concentrações de $\mathrm{N}-\mathrm{NH}_{3}$ no afluente e no efluente ao sistema de reatores, durante o período de operação da seqüência I, está representada na figura 5.11.

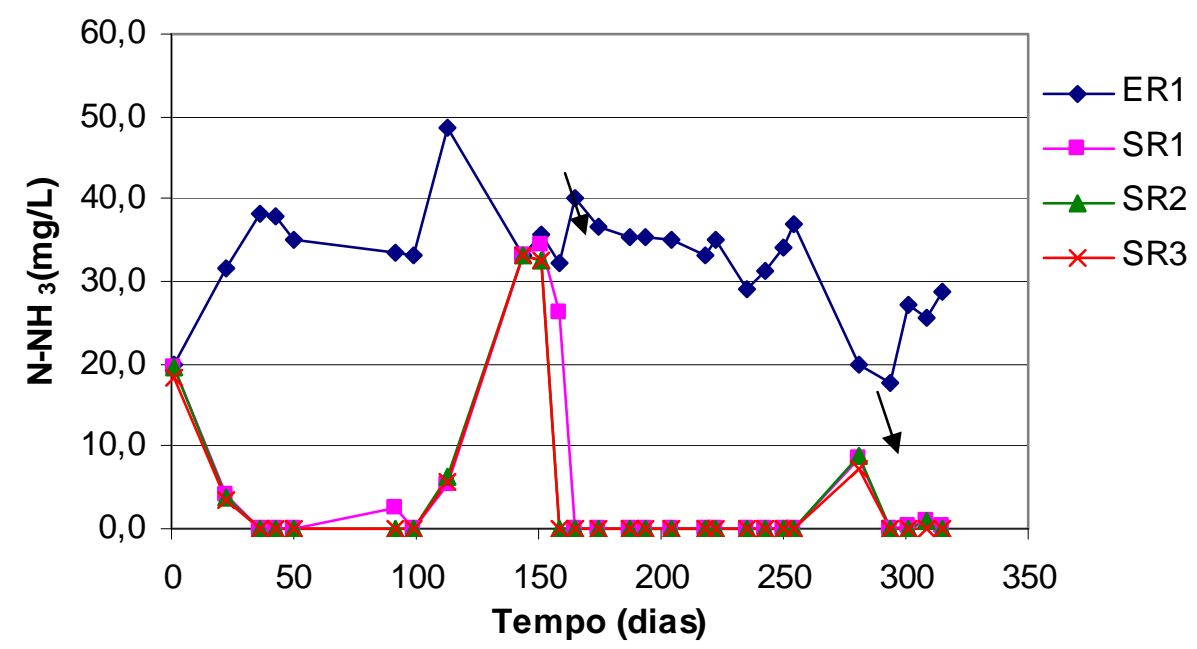

Figura 5.11 - Variação das concentrações de N-NH${ }_{3}$ durante a operação da seqüências I. 
Como pode ser observado na figura 5.11, durante a operação do sistema da seqüência I, os reatores apresentaram elevado potencial de remoção de $\mathrm{N}-\mathrm{NH}_{3}$.

Pode ser observado, também, que próximo ao $150^{\circ}$ dia de operação o sistema teve sua eficiência de conversão de $\mathrm{N}_{-} \mathrm{NH}_{3}$ totalmente reduzida, em virtude do acidente tóxico.

No $144^{\circ}$ dia de operação dos reatores, é possível observar, pela seta, o impacto causado por esse acidente. Para concentração afluente em $\mathrm{N}-\mathrm{NH}_{3}$ igual a 33,3 mg/L a concentração efluente dos três reatores foi a mesma, $33,3 \mathrm{mg} / \mathrm{L}$, evidenciando queda na taxa de conversão de $\mathrm{N}-\mathrm{NH}_{3}$ a N-NO${ }_{3}^{-}$.

Pela figura 5.11 é possível notar, ainda, que as concentrações de $\mathrm{N}^{-\mathrm{NH}_{3}}$ no efluente dos reatores R2 e R3 foram menores que $0,1 \mathrm{mg} / \mathrm{L}$ em grande parte do período de operação correspondente à seqüência I. Isso revela que o processo de conversão de $\mathrm{N}-\mathrm{NH}_{3}$ a $\mathrm{N}-\mathrm{NO}_{3}{ }^{-}$, pode ter sido iniciado em R1, e complementado pelos outros dois reatores.

A figura 5.11 também revela que o sistema foi capaz de suportar os picos de concentração de $\mathrm{N}_{-} \mathrm{NH}_{3}$ no afluente, salvo os dados que refletem os impactos causados por fatores, já mencionados, que prejudicaram o desempenho dos reatores.

Com os dados das tabelas 5.5 e 5.6, respectivamente, é possível estimar o percentual de nitrogênio amoniacal sobre o nitrogênio total Kjedahl, afluente ao sistema de reatores através da relação $\mathrm{N}-\mathrm{NH}_{3} / \mathrm{NTK}$. O valor dessa relação na seqüência I foi igual a 0,8 revelando que em média $80 \%$ do nitrogênio NTK afluente ao sistema era amoniacal.

O reflexo da falha do sistema de aeração também pode ser observado na posição indicada pela seta na figura 5.11, próximo ao $281^{\circ}$ dia de operação, quando o sistema teve sua eficiência na remoção de $\mathrm{N}-\mathrm{NH}_{3}$ comprometida.

$\mathrm{O}$ método empregado para análise da concentração de nitrito $\left(\mathrm{N}-\mathrm{NO}_{2}{ }^{-}\right)$e nitrato $\left(\mathrm{N}^{-} \mathrm{NO}_{3}{ }^{-}\right)$apresenta limite de quantificação de $0,0001 \mathrm{mg} / \mathrm{L}$. Valores abaixo dessa concentração foram considerados não detectados (ND).

Para o afluente ao sistema de reatores essas duas variáveis não foram consideradas por apresentarem valores abaixo da referida quantificação.

As eficiências de nitrificação e desnitrificação não foram estimadas considerando que a conversão de nitrogênio amoniacal a N-NO${ }_{2}^{-} \mathrm{e} \mathrm{N}-\mathrm{NO}_{3}{ }^{-}$ocorreu em um sistema aberto de fluxo contínuo, tornando difícil tal estimativa. 
A tabela 5.7 apresenta os valores, mínimo, máximo, média aritmética e o número de amostras analisadas em cada ponto de coleta, para as variáveis nitrito $(\mathrm{N}-$ $\left.\mathrm{NO}_{2}{ }^{-}\right)$e nitrato $\left(\mathrm{N}-\mathrm{NO}_{3}{ }^{-}\right)$. A tabela apresenta, ainda, o número de resultados das concentrações de nitrito que apresentaram valores menores que $0,01 \mathrm{mg} / \mathrm{L}$.

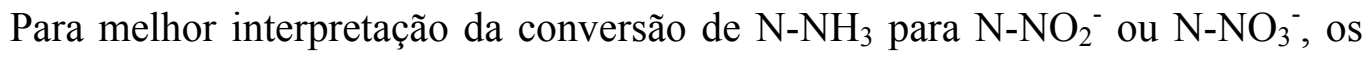
resultados de nitrogênio amoniacal no afluente e no efluente do sistema foram novamente apresentados nessa tabela.

Tabela 5.7 - Valores mínimo, máximo, média aritmética e número de amostras analisadas para os parâmetros $\left(\mathrm{N}_{-} \mathrm{NO}_{2}^{-}\right)$e $\left(\mathrm{N}^{-} \mathrm{NO}_{3}{ }^{-}\right)$e número de amostras com concentração de nitrito menor que $0,01 \mathrm{mg} / \mathrm{L}$.

\begin{tabular}{|c|c|c|c|c|c|}
\hline \multirow{2}{*}{$\begin{array}{l}\mathrm{N}^{-\mathrm{NO}_{2}}{ }^{-} \\
(\mathrm{mg} / \mathrm{L})\end{array}$} & \multicolumn{5}{|c|}{ Seqüência I } \\
\hline & $\begin{array}{c}\text { ER1 } \\
\left(\mathrm{N}-\mathrm{NH}_{3}\right)\end{array}$ & SR1 & SR2 & SR3 & $\begin{array}{c}\mathrm{SR3} \\
\left(\mathrm{N}-\mathrm{NH}_{3}\right)\end{array}$ \\
\hline Média & 32,6 & 2,5 & 2,6 & 2,5 & 3,7 \\
\hline Mínimo & 17,7 & $N D$ & $N D$ & $N D$ & $N D$ \\
\hline Máximo & 48,8 & 33,4 & 29,6 & 27,5 & 33,3 \\
\hline $\mathbf{n}$ & 27 & 27 & 27 & 27 & 27 \\
\hline $\begin{array}{c}\text { Valores }< \\
0,01^{*} \mathrm{mg} / \mathrm{L}\end{array}$ & - & 5 & 10 & 11 & \\
\hline $\begin{array}{l}\mathrm{N}^{-\mathrm{NO}_{3}}{ }^{-} \\
(\mathrm{mg} / \mathrm{L})\end{array}$ & $\begin{array}{c}\text { ER1 } \\
\left(\mathrm{N}-\mathrm{NH}_{3}\right)\end{array}$ & SR1 & SR2 & SR3 & $\begin{array}{c}\mathrm{SR3} \\
\left(\mathrm{N}-\mathrm{NH}_{3}\right)\end{array}$ \\
\hline Média & 32,6 & 25,0 & 25,1 & 25,2 & 3,7 \\
\hline Mínimo & 17,7 & $N D$ & $N D$ & $N D$ & $N D$ \\
\hline Máximo & 48,8 & 37,0 & 37,2 & 37,0 & 33,3 \\
\hline $\mathbf{n}$ & 27 & 27 & 27 & 27 & 27 \\
\hline
\end{tabular}

ND: não detectado

(*) Esse valor não é o limite de detecção do método. Ele foi utilizado somente para demonstrar concentrações muito baixas do parâmetro investigado.

As concentrações de $\mathrm{N}^{-\mathrm{NO}_{2}}{ }^{-}$no efluente do sistema foram 2,5; 2,6 e 2,5 mg/L para os reatores R1, R2 e R3, respectivamente, no período de operação correspondente à seqüência I. Essa média foi afetada pelos dados referentes ao período de recuperação do sistema após o sistema de reatores receber carga tóxica lançada acidentalmente na rede de coleta de esgoto do campus da USP -São Carlos que resultou em acúmulo de nitrito 
nos reatores. Tal acúmulo é identificado nos valores máximos das concentrações de N$\mathrm{NO}_{2}{ }^{-}$que foram 33,4; 29,6 e 27,5 mg/L para os reatores R1, R2 e R3, respectivamente.

Pela análise dos resultados da tabela 5.7, a nitrificação na seqüência I, era iniciada em R1 e concluída nos demais reatores, R2 e R3, respectivamte. Isso pode ser confirmado pelo número de amostras na qual a concentração de nitrito foi muito pequena. Das 27 amostras analisadas para $\mathrm{N}^{-\mathrm{NO}_{2}}{ }^{-}$em $\mathrm{R} 1,5$ delas resultaram em concentrações abaixo de $0,01 \mathrm{mg} / \mathrm{L}$ indicando que todo nitrito possivelmente tivesse sido convertido a nitrato. A mesma conclusão é feita para os resultados de R2 e R3, respectivamente, nos quais 10 e 11 amostras revelaram concentrações abaixo de 0,01 $\mathrm{mg} / \mathrm{L}$ nas 27 amostras tomadas de cada reator. Esses resultados revelam alto potencial em nitrificação.

A oxidação de $\mathrm{N}-\mathrm{NH}_{3}$ para $\mathrm{N}-\mathrm{NO}_{3}{ }^{-}$pode ter sido a principal causa para as pequenas concentrações de $\mathrm{N}_{-} \mathrm{NO}_{2}{ }^{-}$encontradas em SR3. A conversão de $\mathrm{N}^{-\mathrm{NH}_{3}}$ a $\mathrm{N}_{2}$ por via curta, mencionada por VILLAVERDE et al. (2000), pode não ter sido o principal mecanismo para redução das concentrações de nitrito, uma vez que as concentrações de nitrato foram consideráveis no efluente do sistema.

Para melhor compreensão dos dados apresentados na tabela 5.7 um gráfico boxplot foi elaborado conforme representado na figura 5.12.

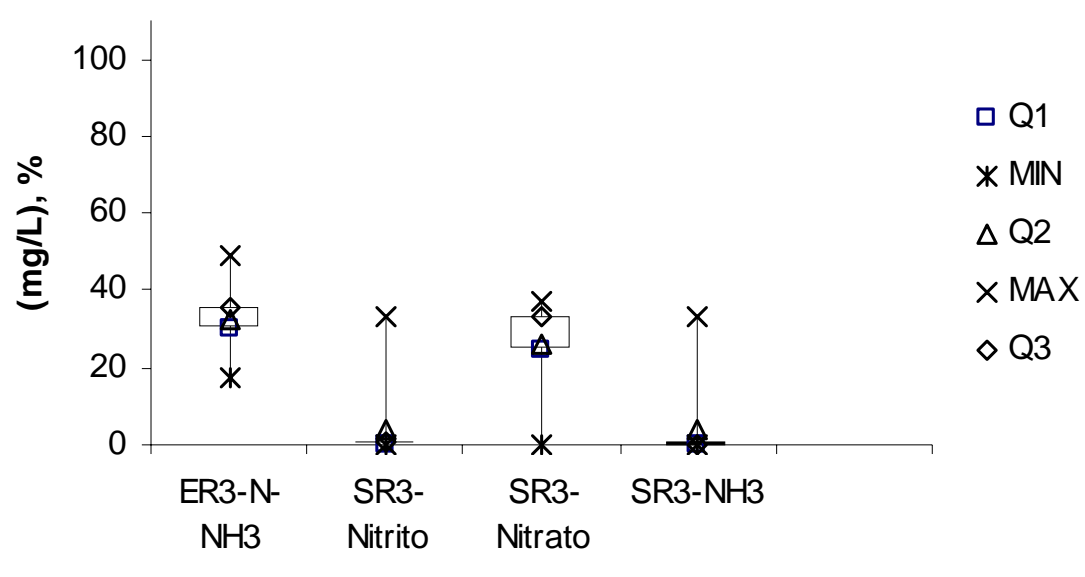

Amostras

Figura 5.12 - Box-plot dos dados relativos aos resultados de nitrificação e desnitificação para a seqüência I.

Pela figura 5.12 é possível observar que para concentração de $\mathrm{N}-\mathrm{NH}_{3}$ no afluente ao sistema de reatores da seqüência I variando entre 30 e $50 \mathrm{mg} / \mathrm{L}$ para $75 \%$ dos resultados, a concentração de $\mathrm{N}_{-} \mathrm{NO}_{2}{ }^{-}$variou entre 0 e $0,6 \mathrm{mg} / \mathrm{L}$. Esse fato corrobora as 
afirmações feitas, anteriormente, de que o sistema possuía elevado potencial de nitrificação.

A figura 5.12 mostra, ainda, que a concentração de $\mathrm{N}_{-} \mathrm{NO}_{3}{ }^{-}$na saída do sistema variou entre 25 e $37 \mathrm{mg} / \mathrm{L}$ em $75 \%$ dos resultados encontrados. Comparando essa faixa de variação com a de $\mathrm{N}-\mathrm{NH}_{3}$, observado no afluente do sistema, é possível concluir que o sistema apresentou atividade desnitrificante, porém, com baixo potencial de conversão a $\mathrm{N}_{2}$. Tal atividade pode ter sido limitada ao interior do biolfime via nitrificação e desnitrificação simultâneas (THIRD, et al., 2005).

O carbono orgânico em quantidade inadequada pode ter sido o fator limitante da desnitrificação no sistema operado na seqüência I. Essa afirmação, corroborada pela variação estatística da relação $\mathrm{DQO} / \mathrm{N}\left(\mathrm{DQO} / \mathrm{N}_{-} \mathrm{NO}_{3}{ }^{-}\right)$no afluente aos reatores $\mathrm{R} 2$ e R3, está representada na figura 5.13.

A relação entre carbônico orgânico disponível e nitrato foi realizada considerando o parâmetro $\mathrm{DQO}$, pois o parâmetro $\mathrm{DBO}_{5,20}$ não foi utilizado em todas as fases da pesquisa.

Os valores da relação $\mathrm{DQO} / \mathrm{N}$ variaram entre 0,7 e 2,4 e 0,4 e 2,2 para os reatores $\mathrm{R} 2$ e $\mathrm{R} 3$, respectivamente, para 75\% das amostras analisadas. CALLADO e FORESTI (2002) observaram desnitrificação completa para relação DQO/N igual a 5,52, utilizando efluente de reator anaeróbio como fonte de carbono. Esse valor esteve muito próximo ao relatado por CHIE-CHIEN TSENG et al. (1998), que utilizaram esgoto doméstico como fonte de carbono para desnitrificação, obtendo relação DQO/N ideal igual a 5,3.

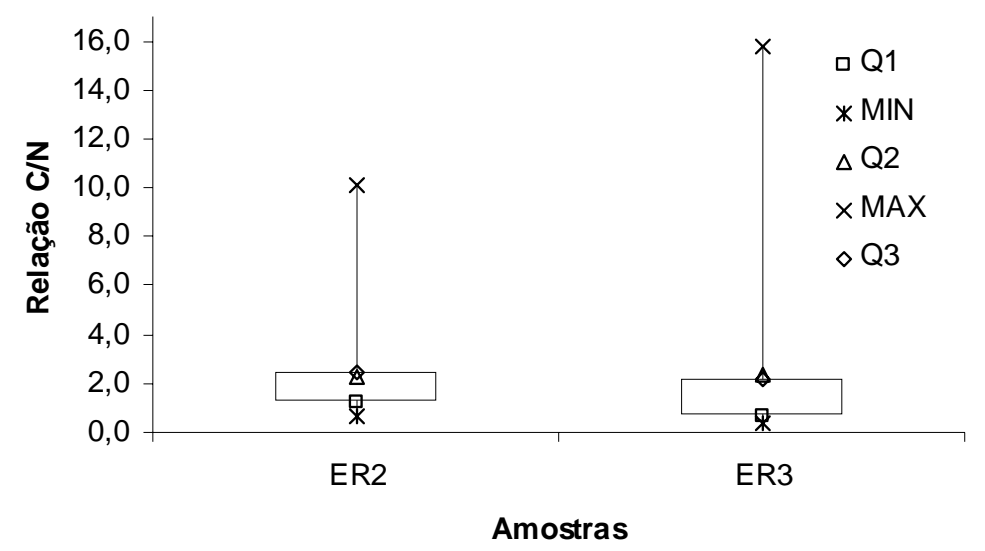

Figura 5.13 - Box-plot da relação $\mathrm{C} / \mathrm{N}$ das amostras afluentes aos reatores $\mathrm{R} 2 \mathrm{e}$ R3 da seqüência I. 
Outro fator que deve considerado, no tocante ao baixo potencial de desnitrificação observado na seqüência I, é a biodisponibilidade da fonte de carbono para as bactérias desnitrificantes. O lodo acumulado no sistema pode não ter sido viável como fonte de carbono para assegurar desnitrificação no reatores R2 e R3, respectivamente. GÓMEZ et. al (2000) verificaram diferenças no potencial de desnitrificação em um sistema empregando sucrose, metanol e etanol como fontes de carbono. Apesar da sucrose ter resultado em maior produção de biomassa, ela não favoreceu o crescimento das bactérias desnitrificantes. Tal crescimento foi observado, porém, nos experimentos que utilizaram metanol e etanol como fontes de carbono. Assim, a quantidade de carbono pode não ser o único fator limitante ao processo de desnitrificação, mas também, sua biodisponibilidade.

A atividade nitrificante pode ser observada pelos dados da tabela 5.8, que apresenta os valores médio, mínimo, máximo e número de amostras analisadas para as variáveis $\mathrm{pH}$ e alcalinidade total em $\mathrm{mg}$ de $\mathrm{CaCO}_{3} / \mathrm{L}$.

Tabela 5.8 - Valores médio, mínimo, máximo e número de amostras analisadas para as variáveis $\mathrm{pH}$ e alcalinidade total em $\mathrm{mg}$ de $\mathrm{CaCO}_{3} / \mathrm{L}$.

\begin{tabular}{|c|c|c|c|c|c|c|c|c|c|}
\hline \multirow{2}{*}{$\begin{array}{c}\text { Alcal. Tot. } \\
\left(\mathrm{mgCaCO}_{3} / \mathrm{L}\right)\end{array}$} & \multicolumn{4}{|c|}{ Seqüência I } & \multirow[b]{2}{*}{$\mathbf{p H}$} & \multicolumn{4}{|c|}{ Seqüência I } \\
\hline & ER1 & SR1 & SR2 & SR3 & & ER1 & SR1 & SR2 & SR3 \\
\hline Méd. & 292 & 57 & 55 & 54 & Méd. & 8,2 & 7,1 & 7,0 & 7,1 \\
\hline Mín. & 223 & 3 & 2 & 2 & Mín. & 6,4 & 5,5 & 5,4 & 5,4 \\
\hline Máx. & 375 & 82 & 79 & 77 & Máx. & 10,6 & 10,6 & 10,0 & 10,0 \\
\hline $\mathbf{n}$ & 11 & 11 & 11 & 11 & $\mathbf{n}$ & 21 & 21 & 21 & 21 \\
\hline
\end{tabular}

Os resultados da tabela 5.8 evidenciam atividade nitrificante no sistema de reatores da seqüência I, como é observado pelo consumo da alcalinidade total. Para alcalinidade média afluente de $292 \mathrm{mg} \mathrm{CaCO}_{3} / \mathrm{L}$, as concentrações médias no efluente dos reatores R1, R2, e R3 foram 57, 55, e $54 \mathrm{mg} \mathrm{CaCO}_{3} / \mathrm{L}$, respectivamente.

A variação estatística dos resultados para as variáveis $\mathrm{pH}$ e alcalinidade total pode ser melhor visualizada na figura 5.14. 

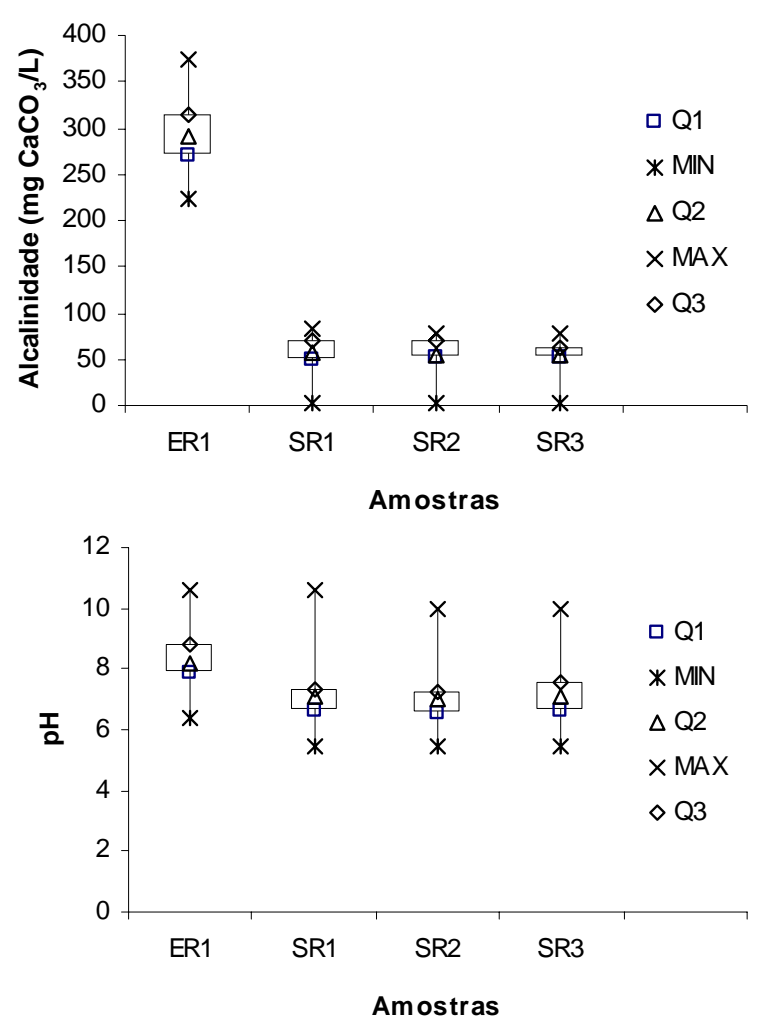

Figura 5.14 - Box-plot dos resultados referentes aos parâmetros pH e alcalinidade total.

A figura 5.14 revela que a alcalinidade total e o $\mathrm{pH}$ no afluente ao sistema de reatores da seqüência I variaram entre 220 e 375 mg $\mathrm{CaCO}_{3} / \mathrm{L}$ e 8 e 11 , respectivamente, em $75 \%$ das amostras investigadas.

A variação da alcalinidade total no efluente do sistema (SR3) para a mesma porcentagem de amostras foi de 51 a $77 \mathrm{mg} \mathrm{CaCO}_{3} / \mathrm{L}$. Esse comportamento estatístico corrobora com a afirmação de verificação de atividade nitrificante no sistema a partir dos dados observados na tabela 5.8.

Pela figura 5.14 é possível observar, ainda, que o sistema apesar da atividade nitrificante que consumiu boa parte da alcalinidade afluente, apresentou capacidade tampão suficiente para manter o $\mathrm{pH}$ variando entre 6,6 e 10 em $75 \%$ das amostras analisadas em SR3. 


\subsubsection{Remoção de Sólidos}

Os resultados das análises para as variáveis sólidos suspensos totais (SST), sólidos suspensos fixos (SSF), sólidos suspensos voláteis (SSV) e relação SSV/SST estão apresentados na tabela 5.9, em valores, máximo, mínimo e média aritmética.

Tabela 5.9 - Valores médio, mínimo, máximo e número de amostras analisadas para os parâmetros SST, SSF, SSV e SSV/SST.

\begin{tabular}{c|cccc}
\hline SST (mg/L) & Afluente & \multicolumn{3}{c}{ Efluente } \\
\cline { 3 - 5 } seqüência I & ER1 & SR1 & SR2 & SR3 \\
\hline Média & 40,6 & 12,6 & 65,7 & 3,2 \\
Mínimo & 8,7 & 3,0 & 1,0 & 0,5 \\
Máximo & 118,0 & 26,6 & 377,5 & 14,1 \\
\hline SSF (mg/L) & Afluente & \multicolumn{3}{c}{ Efluente } \\
seqüência I & ER1 & SR1 & SR2 & SR3 \\
\hline Média & 15,7 & 2,6 & 20,0 & 1,5 \\
Mínimo & 0,0 & 0,0 & 0,0 & 0,0 \\
Máximo & 84,7 & 19,0 & 125,0 & 13,7 \\
\hline SSV (mg/L) & Afluente & & Efluente & \\
seqüência I & ER1 & SR1 & SR2 & SR3 \\
\hline Média & 24,9 & 10,4 & 45,9 & 1,9 \\
Mínimo & 8,0 & 2,0 & 1,0 & 0,4 \\
Máximo & 66,0 & 21,3 & 252,5 & 4,0 \\
\hline SSV/SST & Afluente & & Efluente & \\
\cline { 3 - 5 } seqüência I & ER1 & SR1 & SR2 & SR3 \\
\hline Média & 0,8 & 0,9 & 0,9 & 0,9 \\
Mínimo & 0,3 & 0,3 & 0,5 & 0,0 \\
Máximo & 1,0 & 1,0 & 1,0 & 1,0 \\
n & 10 & 10 & 10 & 10 \\
\hline
\end{tabular}

A seqüência I revelou alto desempenho na remoção de sólidos suspensos conforme dados da tabela 5.9. Para concentrações médias de SST e SSV no afluente , respectivamente, iguais a 40,9 e 24,9 mg/L, as concentrações médias efluente foram 3,2 e 1,9 mg/L. Esses dados podem ser confirmados pelo aspecto bastante clarificado do efluente final do sistema .

Os valores médios de SST e SSV na saída de R2 foram, respectivamente, 65,7 e $45,9 \mathrm{mg} / \mathrm{L}$ evidenciando perda de sólidos nesse reator, como mostra a tabela 5.9. Esse resultado pode ter sido afetado pelo ponto de coleta de amostra nessa seqüência, que era 
localizado na base desse reator, favorecendo o arraste de lodo acumulado no fundo do mesmo.

A relação SSV/ SST apresenta o percentual orgânico sobre o parâmetro SST. Pelos dados da tabela 5.9 é possível notar pela relação SSV/SST que, em média, 80\% dos sólidos suspensos totais afluentes ao sistema eram compostos por material orgânico, enquanto que esse percentual foi, em média, de $90 \%$ para o efluente final do sistema de reatores.

Esses dados mostram também que o suporte empregado pode ter sido adequado como material filtrante, oferecendo barreira física à passagem de sólidos além de superfície adequada para imobilização da biomassa presente nos reatores.

A variação estatística dos resultados referentes à relação SSV/SST para as amostras coletadas na seqüência I está apresentada no gráfico tipo box-plot da figura 5.15 .

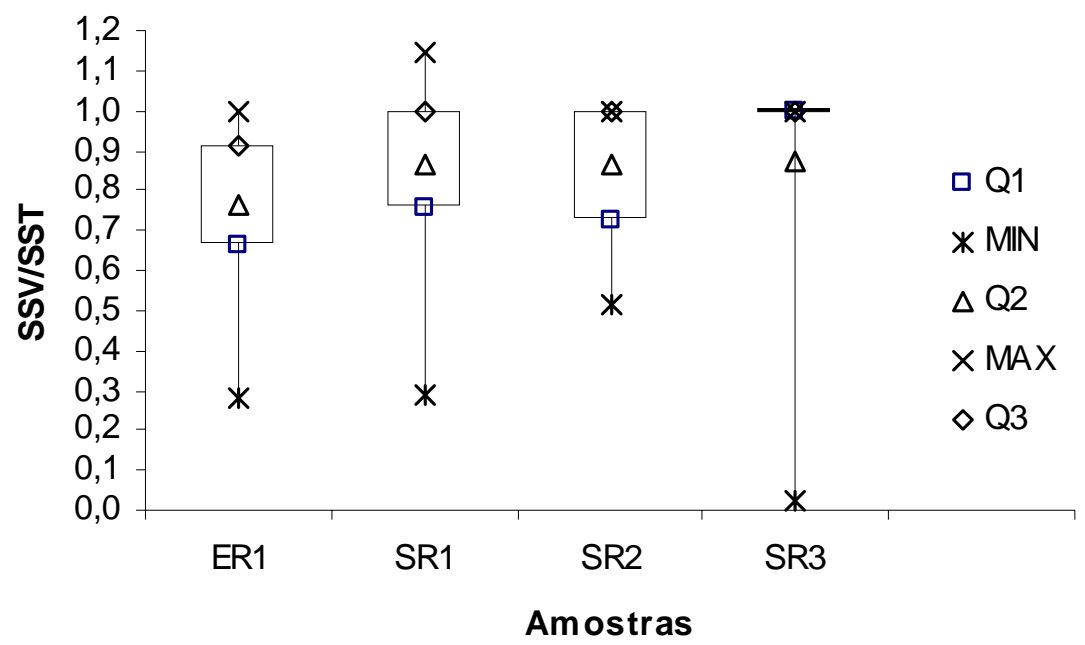

Figura 5.15 - Box-plot da relação SSV/SST para amostras coletadas na seqüência I.

O percentual orgânico da matéria particulada afluente ao sistema de reatores da seqüência I variou entre 70 e 100\% em $75 \%$ das amostras investigadas como mostra a figura 5.15. Essa figura mostra, também, que o percentual orgânico presente na matéria orgânica particulada no efluente do sistema foi praticamente $100 \%$ em $75 \%$ das amostras analisadas. 
Os resultados das análises para as variáveis sólidos totais (ST), sólidos totais fixos (SF), sólidos totais voláteis (SV) e relação SV/ST estão apresentados na tabela 5.10, em valores, máximo, mínimo e média aritmética.

Tabela 5.10 - Valores médio, mínimo, máximo e número de amostras analisadas para os parâmetros ST, SF, SV e SV/ST.

\begin{tabular}{c|cccc}
\hline ST (mg/L) & Afluente & \multicolumn{3}{c}{ Efluente } \\
\cline { 3 - 5 } seqüência I & ER1 & SR1 & SR2 & SR3 \\
\hline Média & 464 & 537 & 568 & 547 \\
Mínimo & 315 & 325 & 376 & 373 \\
Máximo & 687 & 712 & 870 & 865 \\
\hline SF (mg/L) & Afluente & & Efluente & \\
\cline { 3 - 5 } seqüência I & ER1 & SR1 & SR2 & SR3 \\
\hline Média & 223 & 203 & 200 & 195 \\
Mínimo & 51 & 14 & 15 & 10 \\
Máximo & 488 & 414 & 366 & 360 \\
\hline SV (mg/L) & Afluente & & Efluente & SR3 \\
seqüência I & ER1 & SR1 & SR2 & 235 \\
Média & 235 & 334 & 368 & 197 \\
Mínimo & 122 & 198 & 190 & 522 \\
Máximo & 484 & 474 & 504 & SR3 \\
\hline SV/ST & Afluente & & Efluente & 0,66 \\
seqüência I & ER1 & SR1 & SR2 & 0,35 \\
\hline Média & 0,52 & 0,65 & 0,67 & 0,97 \\
Mínimo & 0,26 & 0,37 & 0,47 & 8,96 \\
Máximo & 0,88 & 0,96 & 8 & \\
n & 8 & 8 & & \\
\hline
\end{tabular}

Pela tabela 5.10 é possível observar aumento de sólidos totais do afluente para o efluente do sistema. Para concentração média no afluente de $464 \mathrm{mg} / \mathrm{L}$ a concentração média no efluente foi de $547 \mathrm{mg} / \mathrm{L}$ de sólidos totais, evidenciando tal aumento. Esse comportamento pode ser atribuído ao lodo, que nessa seqüência não era efetuado o descarte, aumentando, assim, a concentração de sólidos no efluente do sistema de reatores.

Embora a análise de sólidos dissolvidos não tenha sido realizado nessa fase, é possível inferir, pelos dados de sólidos em suspensão constantes na tabela 5.9, que a matéria orgânica no efluente do sistema estava em grande parte dissolvida.

A relação SV/ST no afluente ao sistema de reatores variou entre 0,26 e 0,66 em $75 \%$ dos resultados investigados, revelando que variação do percentual orgânico dos 
sólidos totais esteve entre 26 e $66 \%$, como mostra a figura 5.16. Esse percentual variou entre 35 e $73 \%$ no efluente final do sistema.

Esses resultados indicam, indiretamente, baixa produção de lodo no sistema de reatores conforme proposta do projeto idealizado. Isso pode ser atribuído à capacidade de retenção de sólidos em suspensão do leito filtrante empregado.

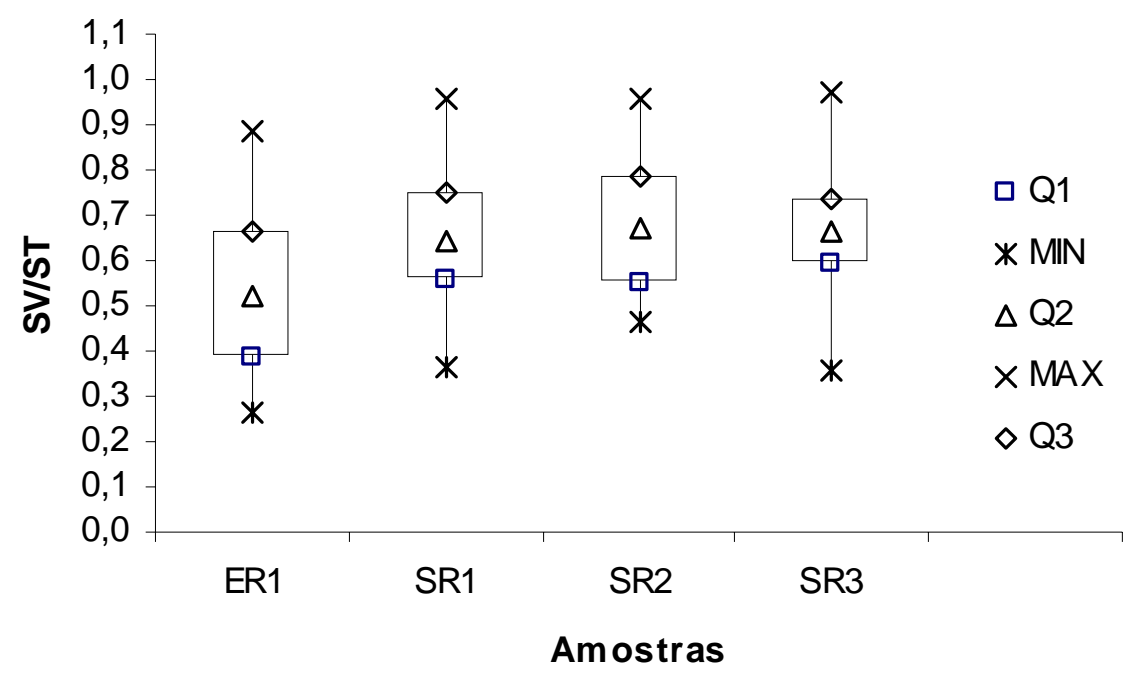

Figura 5.16 - Box-plot da relação SV/ST dos resultados obtidos na seqüência I.

Pela figura 5.17, é possível observar a variação estatística da relação entre sólidos totais fixos e voláteis $(\mathrm{SF} / \mathrm{SV})$ referente ao afluente e efluente do sistema de reatores.

A variação do percentual de sólidos fixos em relação as voláteis do esgoto afluente ao sistema de reatores foi de 54 a 164\% em $75 \%$ das amostras analisas. Apesar de não afetar o desempenho do sistema como unidade de pós-tratamento para remoção de nitrogênio, esse resultado indica necessidade de tratamento físico-químico para remoção de partículas inertes no efluente do reator UASB, caso um estudo mais detalhado verificasse sua viabilidade.

Para o mesmo percentual de amostras investigadas no efluente do sistema, a variação da relação $\mathrm{SF} / \mathrm{SV}$ esteve entre 0,36 e 0,68 . Esse resultado reflete, também, a capacidade de remoção de sólidos do leito filtrante empregado nos reatores do sistema. 


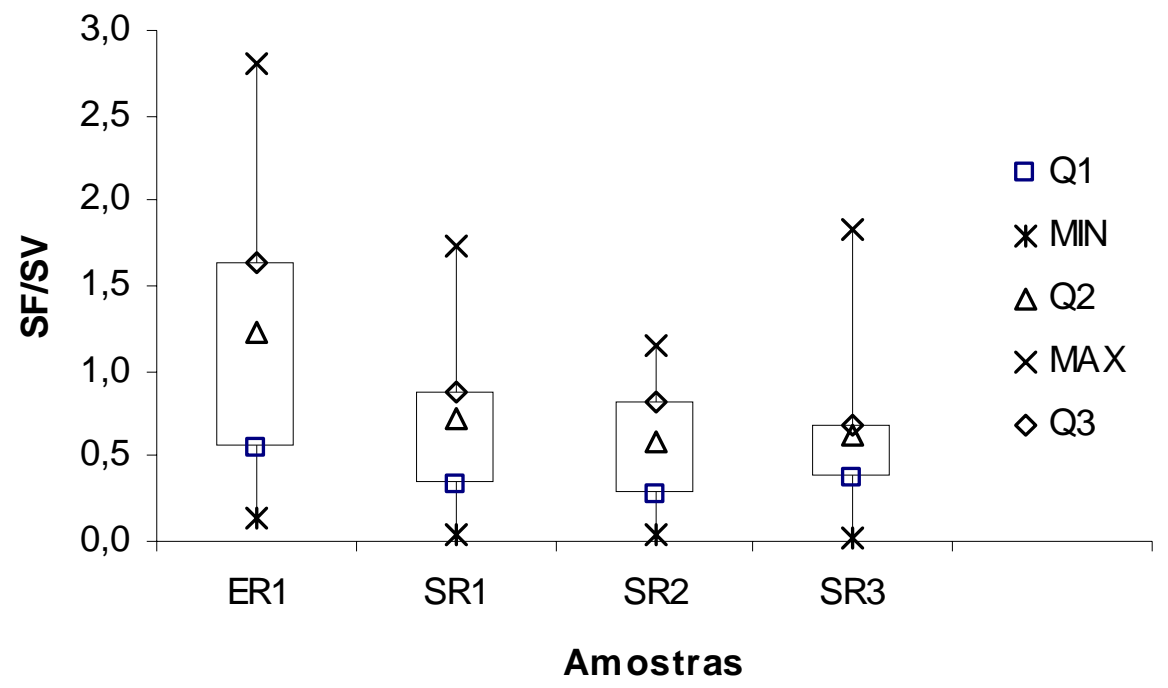

Figura 5.17 - Box-plot da relação SF/SV dos resultados obtidos na seqüência I.

\subsection{Seqüência II}

\subsubsection{Remoção de carbono orgânico total (COT) e DQO}

A tabela 5.11 apresenta os valores médios, mínimos, máximos e número de dados analisados, para o parâmetro carbono orgânico total (COT), durante o período de operação referente à seqüência II, etapa I, do projeto de pesquisa bem como a respectiva eficiência total de remoção.

Tabela 5.11-Valores médio, mínimo, máximo e eficiência total de remoção do sistema em COT para amostras analisadas na seqüência II, etapa I.

\begin{tabular}{c|ccccc}
\hline $\begin{array}{c}\text { COT } \\
\text { (seqüência II - } \\
\text { etapa I) }\end{array}$ & $\begin{array}{c}\text { Afluente } \\
\text { (mg/L) }\end{array}$ & \multicolumn{5}{c}{$\begin{array}{c}\text { Efluente } \\
\text { (mg/L) }\end{array}$} & \begin{tabular}{c} 
Efic. \\
Total \\
\cline { 3 - 5 }
\end{tabular} & ER2 & SR1 & SR2 & SR3 & (\%) \\
\cline { 3 - 5 } Média & 15,17 & 6,93 & 6,90 & 5,68 & 58,61 \\
Mínimo & 7,55 & 5,38 & 4,35 & 4,71 & 32,30 \\
Máximo & 26,19 & 9,49 & 9,16 & 7,16 & 77,74 \\
$\mathbf{n}$ & 5 & 6 & 6 & 8 & 8 \\
\hline
\end{tabular}


Segundo a tabela 5.11, para concentração média de COT no afluente ao sistema igual a $15,17 \mathrm{mg} / \mathrm{L}$, a concentração média no efluente foi de $5,68 \mathrm{mg} / \mathrm{L}$ revelando eficiência média de remoção igual a 58,61\%.

As concentrações máximas, no afluente e no efluente do sistema, foram iguais a 26,19 e $7,16 \mathrm{mg} / \mathrm{L}$, respectivamente. Esses valores revelam a capacidade do sistema em suportar aumento de carga orgânica afluente, sem consideráveis quedas na eficiência de remoção.

O comportamento da variação estatística dos resultados de COT está apresentado na figura 5.18.

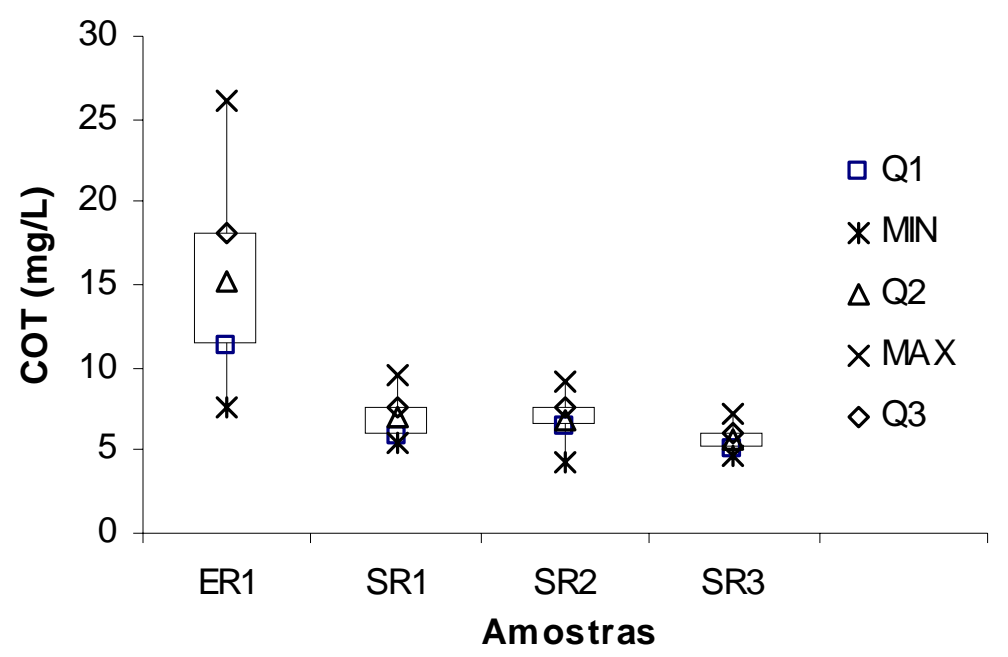

Figura 5.18 - Box-plot do parâmetro COT para resultados obtidos na etapa I da seqüência II.

A variação da concentração de COT no afluente do sistema esteve entre 11 e 26 $\mathrm{mg} / \mathrm{L}$, em $75 \%$ das amostras investigadas como é possível constatar na figura 5.18 . Para mesma percentagem de amostras analisadas no efluente do sistema, essa variação esteve entre 5 e $7 \mathrm{mg} / \mathrm{L}$ revelando a capacidade do sistema em suportar a variação observada na entrada.

As analises de DQO foram retomadas durante a operação da etapa III da seqüência II, pois nessa fase da pesquisa foi utilizado método adequado para quantificação entre 10 e $50 \mathrm{mg} / \mathrm{L}$.

A tabela 5.12 apresenta os valores mínimos, máximos, média aritmética e número de dados analisados para DQO durante o período de operação referente à seqüência II, etapa III, bem como a respectiva eficiência total de remoção. 
Para concentração média afluente ao sistema de reatores operados na etapa III igual $210 \mathrm{mg} / \mathrm{L}$ de DQO a concentração média no efluente foi igual $20 \mathrm{mg} / \mathrm{L}$. Esses resultados revelaram eficiência média total de remoção de DQO igual de 87,8\% (Tabela $5.12)$.

Tabela 5.12-Valores médio, mínimo, máximo e eficiência total de remoção de remoção do sistema em DQO para amostras analisadas na seqüência II, etapa III.

\begin{tabular}{c|cccccc}
\hline $\begin{array}{c}\text { DQO } \\
\text { (seqüência II } \\
\text { - etapa III) }\end{array}$ & $\begin{array}{c}\text { Afluente } \\
\text { (mg/L) }\end{array}$ & \multicolumn{3}{c}{$\begin{array}{c}\text { Efluente } \\
\text { (mg/L) }\end{array}$} & $\begin{array}{c}\text { Efic. } \\
\text { Total }\end{array}$ \\
\cline { 3 - 5 } & ER2 & SR1 & SR2 & SR3 & (\%) \\
\hline Média & 210 & 27 & 48 & 20 & 87,8 \\
Mínimo & 56 & 20 & 20 & 13 & 76,7 \\
Máximo & 304 & 33 & 108 & 26 & 93,7 \\
$\mathbf{n}$ & 5 & 5 & 5 & 5 & 5 \\
\hline
\end{tabular}

Para A variação estatística dos resultados obtidos em DQO está apresentada na figura 5.19.

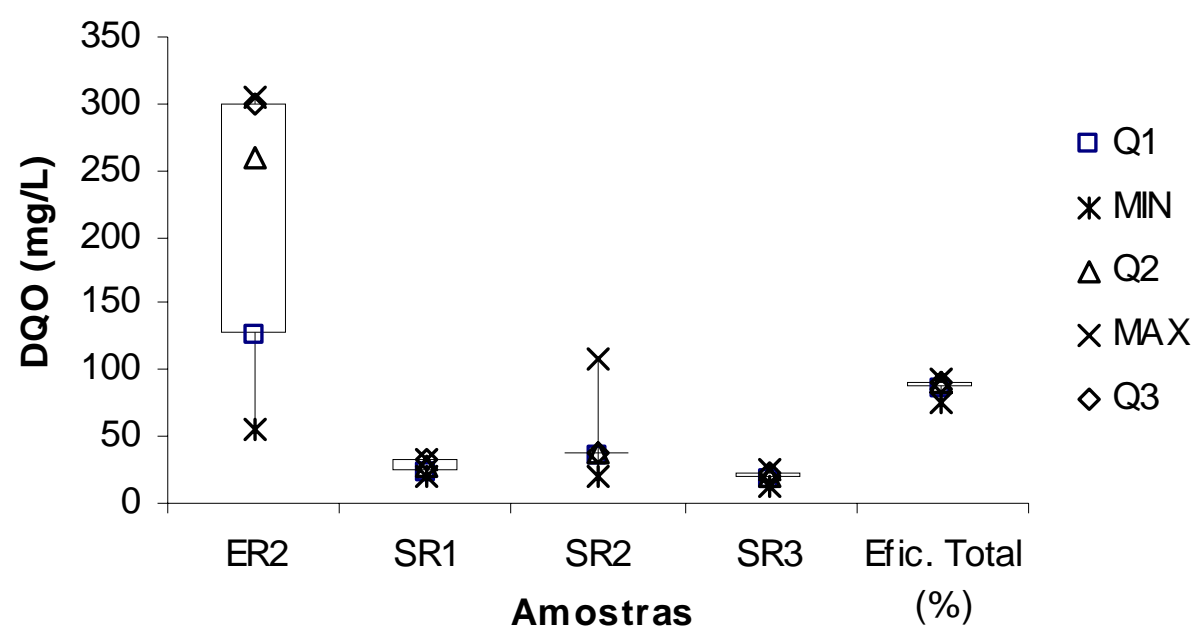

Figura 5.19 - Box-plot referente à DQO para resultados obtidos na etapa III.

Os resultados obtidos para DQO no afluente ao sistema revelam grande dispersão com valores variando aproximadamente entre 125 e $300 \mathrm{mg} / \mathrm{L}$ para $75 \%$ das amostras investigadas. Pouca dispersão, porém, é observada no efluente do sistema, SR3, que estiveram próximos a $20 \mathrm{mg} / \mathrm{L}$ de DQO em praticamente $100 \%$ das amostras analisadas. Esses resultados evidenciam que o sistema projetado era capaz de suportar eventuais sobrecargas em DQO. 


\subsubsection{Remoção de Nitrogênio}

Os resultados referentes à conversão de NTK na seqüência II - etapas I, II e III estão apresentados nas tabelas 5.13, 5.14 e 5.15, respectivamente, que ilustram os valores mínimo, máximo, média aritmética e eficiência total de conversão para amostras analisadas. Essas tabelas mostram, também, o número de amostras cujo valor da concentração de NTK não foi detectada (ND).

Na seqüência II, o R2 teve o papel de oferecer, ao efluente recirculado de R1, condições para desnitrificação. Assim, a carga em NTK afluente ao sistema não era convertida em R2, e o valor da concentração no efluente desse reator é resultado da vazão de recirculação $R_{c}$ revelando eficiência de conversão aparente.

Os dados observados nas tabelas 5.13 a 5.15 mostram que grande parte da carga em NTK afluente ao sistema era convertida no R1, ficando R3 com o papel de complementar a conversão.

A partir de certo período de operação na seqüência II - etapa I foi observado que o sistema estava em equilíbrio dinâmico aparente na conversão de NTK. Assim, até que qualquer outra mudança no sistema fosse aplicada, ou seja, operação das etapas II e III, respectivamente, o potencial do sistema na remoção de DQO nessa etapa, foi monitorado mediante a caracterização do afluente e do efluente do sistema. Logo, o número de amostras analisadas para ER1 e SR3 é o mesmo como consta na tabela 5.13.

Tabela 5.13 - Valores mínimo, máximo, média aritmética e eficiência total do sistema em relação a NTK para amostras analisadas, na seqüência II - etapa I, e número de amostras com concentração não detectada.

\begin{tabular}{|c|c|c|c|c|c|}
\hline \multirow{2}{*}{$\begin{array}{c}\text { NTK } \\
\text { (Seqüência II } \\
\text { - etapa I) }\end{array}$} & \multirow{2}{*}{$\begin{array}{c}\text { Afluente } \\
\text { (mg/L) } \\
\text { ER2 }\end{array}$} & \multicolumn{3}{|c|}{$\begin{array}{c}\text { Efluente } \\
\text { (mg/L) }\end{array}$} & \multirow{2}{*}{$\begin{array}{c}\text { Efic. } \\
\text { Total } \\
(\%)\end{array}$} \\
\hline & & SR1 & SR2 & SR3 & \\
\hline Média & 37,6 & 4,0 & 15,9 & 0,2 & 98,1 \\
\hline Mínimo & 24,2 & $N D$ & 12,8 & $N D$ & 92,0 \\
\hline Máximo & 75,5 & 17,2 & 18,6 & 6,0 & 100,0 \\
\hline $\mathbf{n}$ & 11 & 6 & 6 & 11 & 11 \\
\hline $\begin{array}{l}\text { Valores < } \\
0,1 \mathrm{mg} / \mathrm{L}\end{array}$ & 0 & 1 & 0 & 7 & - \\
\hline
\end{tabular}


Tabela 5.14 - Valores médio, mínimo, máximo e eficiência total do sistema em relação a NTK para amostras analisadas, na seqüência II - etapa II, e número de amostras com concentração não detectada.

\begin{tabular}{c|ccccc}
\hline $\begin{array}{c}\text { NTK } \\
\text { (Seqüência II - } \\
\text { etapa II) }\end{array}$ & $\begin{array}{c}\text { Afluente } \\
\text { (mg/L) }\end{array}$ & \multicolumn{5}{c}{$\begin{array}{c}\text { Efluente } \\
\text { (mg/L) }\end{array}$} & \begin{tabular}{c} 
Efic. \\
Total \\
\cline { 3 - 5 }
\end{tabular} & ER2 & SR1 & SR2 & SR3 & (\%) \\
\cline { 3 - 5 } Média & 62,0 & 9,7 & 18,2 & 9,0 & 86,5 \\
Mínimo & 52,4 & 3,4 & 15,1 & 3,4 & 74,2 \\
Máximo & 80,1 & 20,7 & 20,7 & 20,7 & 94,4 \\
$\mathbf{n}$ & 4 & 4 & 4 & 4 & 4 \\
$\begin{array}{c}\text { Valores < 0,1 } \\
\text { mg/L }\end{array}$ & 0 & 0 & 0 & 0 & - \\
\hline
\end{tabular}

Tabela 5.15 - Valores médio, mínimo, máximo e eficiência total do sistema em relação a NTK para amostras analisadas, na seqüência II - etapa III, e número de amostras com concentração não detectada.

\begin{tabular}{c|ccccc}
\hline $\begin{array}{c}\text { NTK } \\
\text { (Seqüência II - } \\
\text { etapa III) }\end{array}$ & $\begin{array}{c}\text { Afluente } \\
\text { (mg/L) }\end{array}$ & \multicolumn{5}{c}{$\begin{array}{c}\text { Efluente } \\
\text { (mg/L) }\end{array}$} & $\begin{array}{c}\text { Efic. } \\
\text { Total } \\
\text { ER2 }\end{array}$ & SR1 & SR2 & SR3 & (\%) \\
\cline { 3 - 5 } Média & 45,8 & 7,7 & 15,4 & 5,8 & 87,9 \\
Mínimo & 36,5 & 5,4 & 8,8 & 1,8 & 81,5 \\
Máximo & 61,7 & 11,5 & 23,3 & 11,4 & 95,3 \\
$\mathbf{n}$ & 6 & 6 & 6 & 6 & 6 \\
$\begin{array}{c}\text { Valores < 0,1 } \\
\text { mg/L }\end{array}$ & 0 & 0 & 0 & 0 & - \\
\hline
\end{tabular}

As concentrações médias no afluente ao sistema de reatores em cada etapa realizada durante a seqüência II foram, respectivamente, 37,6, 62,0 e 45,8 mg/L de NTK, nas etapas I, II e III, conforme apresentam as tabelas 5.13, 5.14 e 5,15, enquanto que as concentrações efluentes médias foram iguais a $0,2,9,0$ e 5,8 mg/L de NTK.

Uma pequena queda na eficiência total de conversão de NTK do sistema de reatores foi observada da etapa I, para as etapas II e III. Esse resultado pode ser atribuído ao aumento da concentração de NTK no afluente aos sistemas das etapas II e III que em média foram 62,0 e $45,8 \mathrm{mg} / \mathrm{L}$ respectivamente. 
As três etapas, em geral, revelaram grande potencial para conversão de NTK com eficiências totais médias de conversão iguais a 98,1, 86,5 e 87,9\%.

Pela observação das figuras 5.20, 5.21 e 5.22 é possível o verificar o comportamento estatísticos dos resultados obtidos na seqüência II, etapas I, II e III, respectivamente.

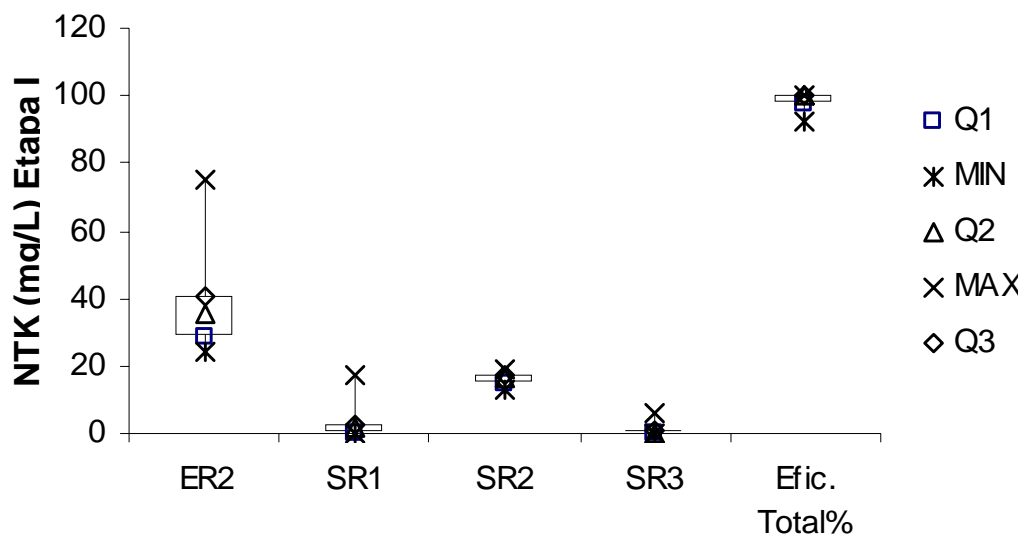

Amostras

Figura 5.20 - Box-plot do parâmetro NTK para resultados obtidos na etapa I, seq. II.

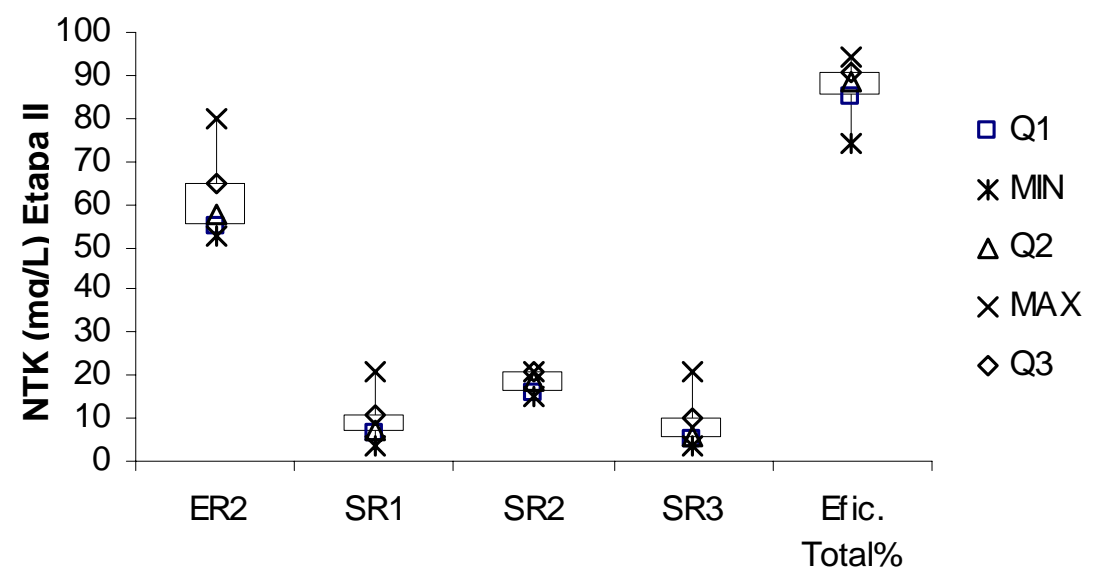

Amostras

Figura 5.21 - Box-plot do parâmetro NTK para resultados obtidos na etapa II, seq. II. 


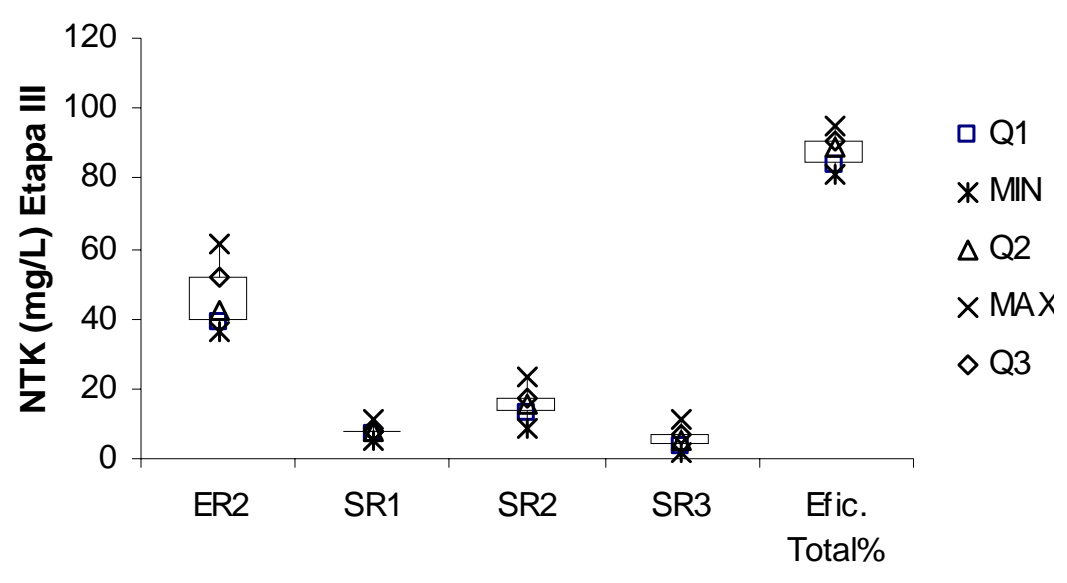

Amostras

Figura 5.22 - Box-plot do parâmetro NTK para resultados obtidos na etapa III, seq.II.

A concentração de NTK no afluente ao sistema nas etapas, I, II e III, variaram entre 24 e 40,52 e 65 e 37 e $52 \mathrm{mg} / \mathrm{L}$, respectivamente, em $75 \%$ da amostras investigadas (figuras 5.20 a 5.22). Esses resultados mostram que as maiores concentrações afluentes de NTK foram constatadas na etapa II. Para mesma porcentagem de amostras investigadas, a variação da concentração de NTK no efluente do sistema esteve entre não detectado e 1, 3 e 10 e 2 e 7 nas etapas I, II e III, respectivamente.

A eficiência total de conversão de NTK variou entre 92 e 100\%, 85 e $94 \%$ e 84 e $95 \%$ em $75 \%$ dos resultados obtidos na operação das etapas I, II e III, respectivamente (figuras 5.20 a 5.22). Esses valores mostram que os sistemas operados nas seqüências II e III, tiveram praticamente, o mesmo desempenho na conversão de NTK.

Após o período de operação da seqüência II - etapa I na qual foi verificada estabilidade do sistema na conversão de $\mathrm{N}-\mathrm{NH}_{3}$, as amostras coletadas no efluente dos reatores R1 e R2 não foram mais consideradas sendo efetuado, penas, o monitoramento global do sistema para essa variável com os dados do afluente, ER1, e do efluente, SR3, do conjunto de reatores.

Os resultados referentes à conversão de $\mathrm{N}_{-} \mathrm{NH}_{3}$ na seqüência II - etapas I, II e III estão apresentados nas tabelas 5.16, 5.17 e 5.18, respectivamente, que ilustram os valores mínimo, máximo, média aritmética e eficiência total de conversão para as amostras analisadas. Essas tabelas mostram, também, o número de amostras cujo valor da concentração de $\mathrm{N}-\mathrm{NH}_{3}$ não foi detectada (ND). 
Tabela 5.16-Valores mínimo, máximo, média aritmética e eficiência total do sistema em relação a $\mathrm{N}-\mathrm{NH}_{3}$ para amostras analisadas, na seqüência II - etapa I, e número de amostras com concentração não detectada.

\begin{tabular}{|c|c|c|c|c|c|}
\hline \multirow{2}{*}{$\begin{array}{c}\mathrm{N}-\mathrm{NH}_{3} \\
\text { (Seqüência II - } \\
\text { etapa I) }\end{array}$} & \multirow{2}{*}{$\begin{array}{c}\text { Afluente } \\
\text { (mg/L) } \\
\text { ER2 }\end{array}$} & \multicolumn{3}{|c|}{$\begin{array}{c}\text { Efluente } \\
\text { (mg/L) }\end{array}$} & \multirow{2}{*}{$\begin{array}{l}\text { Efic. } \\
\text { Total } \\
(\%)\end{array}$} \\
\hline & & SR1 & SR2 & SR3 & \\
\hline Média & 34,2 & 0,2 & 14,8 & 0,2 & 99,6 \\
\hline Mínimo & 22,0 & ND & 11,0 & ND & 97,4 \\
\hline Máximo & 49,9 & 0,6 & 18,9 & 0,6 & 100,0 \\
\hline $\mathbf{n}$ & 11 & 6 & 6 & 11 & 11 \\
\hline $\begin{array}{c}\text { Valores }<0,1 \\
\mathrm{mg} / \mathrm{L}\end{array}$ & - & 3 & - & 10 & - \\
\hline
\end{tabular}

Tabela 5.17-Valores mínimo, máximo, média aritmética e eficiência total do sistema em relação a $\mathrm{N}-\mathrm{NH}_{3}$ para amostras analisadas, na seqüência II - etapa II, e número de amostras com concentração não detectada.

\begin{tabular}{|c|c|c|c|c|c|}
\hline \multirow{2}{*}{$\begin{array}{c}\mathrm{N}_{-\mathrm{NH}_{3}} \\
\text { (Seqüência II } \\
\text { - etapa II) }\end{array}$} & \multirow{2}{*}{$\begin{array}{c}\text { Afluente } \\
\text { (mg/L) } \\
\text { ER2 }\end{array}$} & \multicolumn{3}{|c|}{$\begin{array}{c}\text { Efluente } \\
\text { (mg/L) }\end{array}$} & \multirow{2}{*}{$\begin{array}{c}\text { Efic. } \\
\text { Total } \\
(\%)\end{array}$} \\
\hline & & SR1 & SR2 & SR3 & \\
\hline Média & 40,2 & 0,60 & 10,5 & ND & 99,8 \\
\hline Mínimo & 38,2 & ND & 8,9 & ND & 99,3 \\
\hline Máximo & 41,3 & 1,3 & 12,2 & 0,3 & 100,00 \\
\hline $\mathbf{n}$ & 4 & 4 & 4 & 4 & 4 \\
\hline $\begin{array}{l}\text { Valores < } \\
0,1 \mathrm{mg} / \mathrm{L}\end{array}$ & - & 1 & - & 3 & - \\
\hline
\end{tabular}

Os dados da seqüência II-etapa I revelam que para concentração média no afluente ao sistema de $34,2 \mathrm{mg} \mathrm{N}-\mathrm{NH}_{3} / \mathrm{L}$ o efluente dos reatores R1, R2 e R3 apresentou concentrações médias iguais a 0,$2 ; 14,8$ e $0,2 \quad \mathrm{mg} \quad \mathrm{N}_{-} \mathrm{NH}_{3} \quad / \mathrm{L}$, respectivamente. Das seis amostras efluentes de R1 analisadas, três resultaram em concentração menor que $0,1 \mathrm{mg} \mathrm{N}-\mathrm{NH}_{3} / \mathrm{L}$, sendo que a concentração média dos resultados de saída desse reator foi de $0,2 \mathrm{mg} / \mathrm{L}$. Isso revela que a maior parte da conversão de $\mathrm{N}_{-} \mathrm{NH}_{3}$ estava ocorrendo em R1, conforme idealização do projeto. Para 11 amostras analisadas no efluente de R3, 10 resultaram em valores menores que $0,1 \mathrm{mg} / \mathrm{L}$ de $\mathrm{N}_{-} \mathrm{NH}_{3}$. Isso revela que o sistema apresentou alto potencial de conversão de $\mathrm{N}^{-\mathrm{NH}_{3}}$ com eficiência média 99,6\% durante operação da etapa I (tabela 5.16). 
Tabela 5.18-Valores mínimo, máximo, média aritmética e eficiência total do sistema em relação a $\mathrm{N}-\mathrm{NH}_{3}$ para amostras analisadas, na seqüência II - etapa III, e número de amostras com concentração não detectada.

\begin{tabular}{|c|c|c|c|c|c|}
\hline \multirow[t]{2}{*}{$\begin{array}{c}\mathrm{N}^{-\mathrm{NH}_{3}} \\
\text { (Seqüência II - } \\
\text { etapa III) }\end{array}$} & \multirow{2}{*}{$\begin{array}{c}\text { Afluente } \\
\text { (mg/L) } \\
\text { ER2 }\end{array}$} & \multicolumn{3}{|c|}{$\begin{array}{c}\text { Efluente } \\
\text { (mg/L) }\end{array}$} & \multirow{2}{*}{$\begin{array}{c}\text { Efic. } \\
\text { Total } \\
(\%)\end{array}$} \\
\hline & & SR1 & SR2 & SR3 & \\
\hline Média & 33,7 & 0,31 & 7,9 & 0,2 & 99,5 \\
\hline Mínimo & 27,8 & ND & 5,6 & ND & 98,6 \\
\hline Máximo & 39,3 & 1,4 & 9,8 & 0,5 & 100,00 \\
\hline $\mathbf{n}$ & 6 & 6 & 6 & 6 & 6 \\
\hline $\begin{array}{c}\text { Valores }<0,1 \\
\mathrm{mg} / \mathrm{L}\end{array}$ & - & 4 & - & 4 & - \\
\hline
\end{tabular}

As etapas II e III revelaram alto potencial de conversão de $\mathrm{N}-\mathrm{NH}_{3}$ com eficiências totais de conversão iguais 99,8 e $99,5 \%$, respectivamente. Para concentrações médias no afluente aos sistemas das etapas II e III, iguais a 40,2 e 33,7 $\mathrm{mg} / \mathrm{L}$, as concentrações médias no efluentes foram não detectada (ND) e $0,2 \mathrm{mg} / \mathrm{L}$, respectivamente (tabelas 5.17 e 5.18).

O resultado de SR2, em todas as etapas, é apenas o reflexo da diluição promovida nos sistema pela recirculação efetuada entre os reatores R1 e R2, respectivamente.

Esses resultados evidenciam que a carga de nitrogênio amoniacal afluente ao sistema de reatores, em todas as etapas da seqüência II, estava sendo convertida a nitrato em sua quase totalidade.

O comportamento da variação estatística dos resultados obtidos na seqüência IIetapas I, II e III está apresentado nas figuras 5.23, 5.24 e 5.25, respectivamente. 


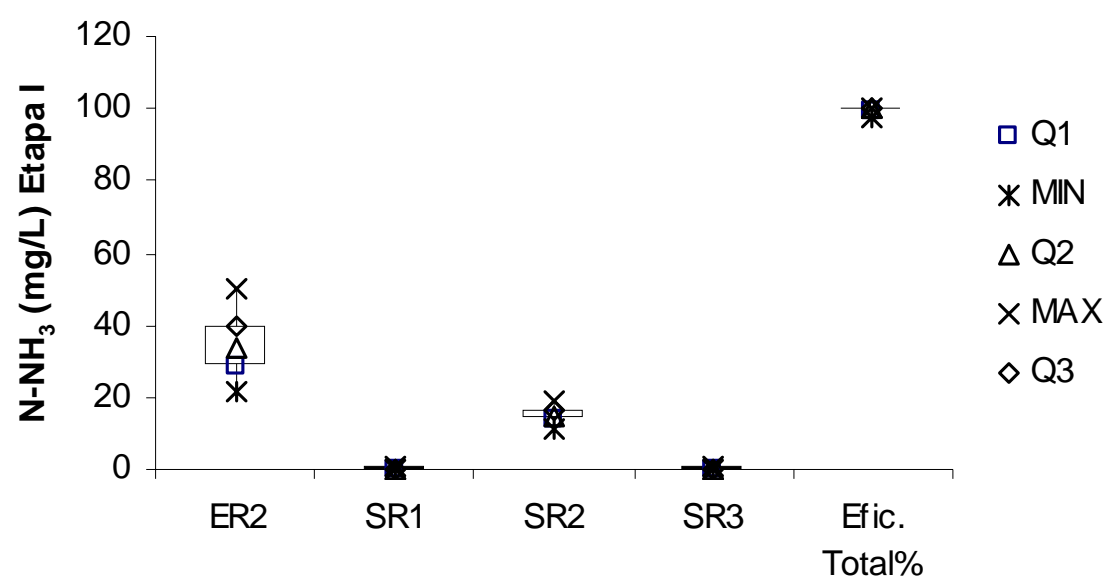

Amostras

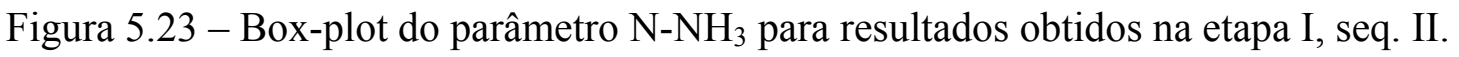

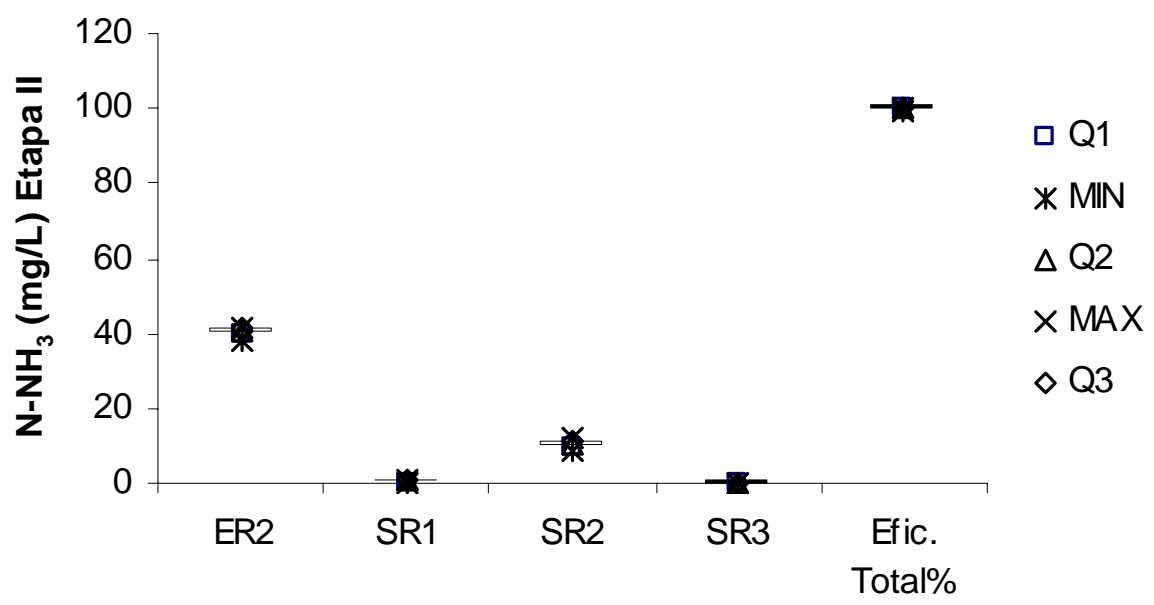

Amostras

Figura 5.24 - Box-plot do parâmetro $\mathrm{N}-\mathrm{NH}_{3}$ para resultados obtidos na etapa II, seq. II.

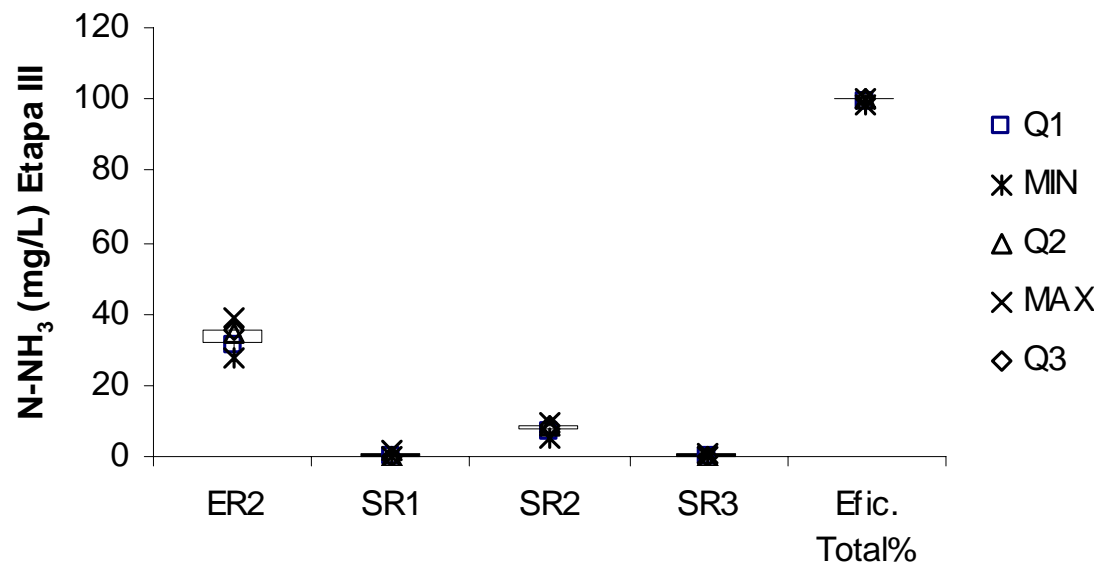

Amostras

Figura 5.25 - Box-plot do parâmetro N-NH 3 para resultados obtidos na etapa III, seq.II. 
As concentrações de $\mathrm{N}-\mathrm{NH}_{3}$ no afluente variaram entre 30 e $50 \mathrm{mg} / \mathrm{L}$, para a etapa I em $75 \%$ das amostras investigadas e entre 30 e $40 \mathrm{mg} / \mathrm{L}$, para etapa III, também em $75 \%$ das amostras. Na etapa II a concentração afluente esteve próxima a $40 \mathrm{mg} / \mathrm{L}$ em praticamente $100 \%$ das amostras investigadas.

Pela análise das figuras 5.23 a 5.25, é possível notar que a eficiência total de conversão de $\mathrm{N}^{-\mathrm{NH}_{3}}$ esteve próxima a $100 \%$ em praticamente $100 \%$ das amostras investigadas em todas as etapas de operação da seqüência II. Esse resultado revela que o sistema apresentou considerável estabilidade na conversão de $\mathrm{N}-\mathrm{NH}_{3}$ durante as três etapas investigadas. É possível observar, também, que a concentração no efluente, dos reatores R1 e R3 esteve próxima ao valor não detectado (ND) em quase todas as amostras investigadas em todas as etapas dessa fase da pesquisa.

Os valores mínimo, máximo, média aritmética e o número de amostras analisadas em cada ponto de coleta, para as variáveis nitrito $\left(\mathrm{N}-\mathrm{NO}_{2}{ }^{-}\right)$e nitrato $\left(\mathrm{N}_{-} \mathrm{NO}_{3}\right)$, observados nas etapas I, II e III estão apresentados nas tabelas 5.19 a 5.21, respectivamente. As tabelas apresentam, ainda, o número de resultados das concentrações de nitrito que apresentaram valores menores que $0,01 \mathrm{mg} / \mathrm{L}$ (Valores < $0,01)$.

Para auxiliar a interpretação da conversão de $\mathrm{N}-\mathrm{NH}_{3}$ para $\mathrm{N}-\mathrm{NO}_{2}{ }^{-} \mathrm{ou} \mathrm{N}-\mathrm{NO}_{3}{ }^{-}$, os resultados de nitrogênio amoniacal no afluente e no efluente do sistema foram novamente inseridos nessas tabelas. 
Tabela 5.19 - Valores mínimo, máximo, média aritmética e número de amostras analisadas para os parâmetros $\left(\mathrm{N}^{-\mathrm{NO}_{2}}{ }^{-}\right)$e $\left(\mathrm{N}^{-\mathrm{NO}_{3}}{ }^{-}\right)$e número de amostras com concentração de nitrito menor que $0,01 \mathrm{mg} / \mathrm{L}$ encontrados na etapa I, sequência II.

\begin{tabular}{|c|c|c|c|c|c|}
\hline \multirow{2}{*}{$\begin{array}{l}\mathrm{N}-\mathrm{NO}_{2}{ }^{-} \\
(\mathrm{mg} / \mathrm{L})\end{array}$} & \multicolumn{5}{|c|}{ Etapa I } \\
\hline & $\begin{array}{c}\text { ER2 } \\
\left(\mathrm{N}-\mathrm{NH}_{3}\right)\end{array}$ & SR1 & SR2 & SR3 & $\begin{array}{c}\mathrm{SR3} \\
\left(\mathrm{N}-\mathrm{NH}_{3}\right)\end{array}$ \\
\hline Média & 34,2 & 0,0042 & 0,2097 & 0,0033 & 0,1 \\
\hline Mínimo & 22,0 & $N D$ & 0,0033 & 0,0023 & ND \\
\hline Máximo & 49,9 & 0,0073 & 1,0700 & 0,0050 & 0,6 \\
\hline $\mathbf{n}$ & 11 & 7 & 7 & 11 & 11 \\
\hline $\begin{array}{c}\text { Valores < } \\
0,01 \mathrm{mg} / \mathbf{L}^{*}\end{array}$ & - & 7 & 1 & 11 & - \\
\hline $\begin{array}{l}\mathrm{N}-\mathrm{NO}_{3}{ }^{-} \\
(\mathrm{mg} / \mathrm{L})\end{array}$ & $\begin{array}{c}\text { ER2 } \\
\left(\mathrm{N}-\mathrm{NH}_{3}\right)\end{array}$ & SR1 & SR2 & SR3 & $\begin{array}{c}\mathrm{SR3} \\
\left(\mathrm{N}-\mathrm{NH}_{3}\right)\end{array}$ \\
\hline Média & 34,2 & 23,0 & 8,0 & 22,6 & 0,1 \\
\hline Mínimo & 22,0 & 16,8 & 2,5 & 16,4 & ND \\
\hline Máximo & 49,9 & 28,3 & 13,4 & 30,7 & 0,6 \\
\hline $\mathbf{n}$ & 11 & 6 & 6 & 11 & 11 \\
\hline
\end{tabular}

(*) Esse valor não é o limite de detecção do método.

Os resultados da tabela 5.19 mostram que o sistema de reatores na etapa I apresentou alto potencial para conversão de nitrogênio amoniacal. Para concentrações médias de $\mathrm{N}^{-\mathrm{NH}_{3}}$ no afluente e no efluente iguais a $34,2 \mathrm{mg} / \mathrm{L}$ e $0,1 \mathrm{mg} / \mathrm{L}$, respectivamente, as concentrações efluentes de $\mathrm{N}^{-\mathrm{NO}_{2}}{ }^{-}$em cada reator, responsável pela nitrificação, foram inferiores a $0,01 \mathrm{mg} / \mathrm{L}$. Esses resultados indicam que a carga de nitrogênio amoniacal afluente ao sistema foi, em quase sua totalidade, convertida a $\mathrm{N}$ $\mathrm{NO}_{3}{ }^{-}$. O mesmo desempenho na conversão de $\mathrm{N}-\mathrm{NH}_{3}$ a N-NO${ }_{3}{ }^{-}$também foi observado nas etapas II e III, como é possível constatar pelos resultados apresentados na tabelas 5.20 e 5.21 , respectivamente. 
Um pequeno aumento no potencial de desnitrificação do sistema, com a mudança da seqüência I para a seqüência II - etapa I, pode ser observado comparando os dados das tabelas 5.7 e 5.19, respectivamente. Na seqüência I para concentração média de $\mathrm{N}_{-} \mathrm{NH}_{3}$ afluente igual a $32,6 \mathrm{mg} / \mathrm{L}$ a concentração efluente média em relação ao $\mathrm{N}$ $\mathrm{NO}_{3}{ }^{-}$foi igual a $25,2 \mathrm{mg} / \mathrm{L}$, enquanto que na seqüência II- etapa I para concentração média no afluente em relação a $\mathrm{N}_{-} \mathrm{NH}_{3}$ igual a $34,2 \mathrm{mg} / \mathrm{L}$ a concentração média de $\mathrm{N}$ $\mathrm{NO}_{3}{ }^{-}$no efluente foi igual a $22,6 \mathrm{mg} / \mathrm{L}$.

Tabela 5.20 - Valores mínimo, máximo, média aritmética, número de amostras

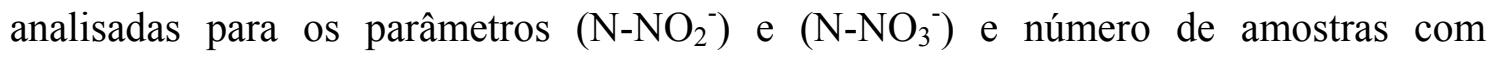
concentração de nitrito menor que $0,01 \mathrm{mg} / \mathrm{L}$ encontrados na etapa II, sequência II.

\begin{tabular}{|c|c|c|c|c|c|}
\hline \multirow{2}{*}{$\begin{array}{l}\mathrm{N}-\mathrm{NO}_{2}{ }^{-} \\
(\mathrm{mg} / \mathrm{L})\end{array}$} & \multicolumn{5}{|c|}{ Etapa II } \\
\hline & $\begin{array}{c}\text { ER2 } \\
\left(\mathrm{N}-\mathrm{NH}_{3}\right)\end{array}$ & SR1 & SR2 & SR3 & $\begin{array}{r}\mathrm{SR3} \\
\left(\mathrm{N}-\mathrm{NH}_{3}\right)\end{array}$ \\
\hline Média & 40,16 & 0,00298 & 0,00878 & 0,00393 & ND \\
\hline Mínimo & 38,24 & 0,0016 & 0,0072 & 0,003 & ND \\
\hline Máximo & 41,26 & 0,0039 & 0,0108 & 0,0046 & 0,29 \\
\hline $\mathbf{n}$ & 4 & 4 & 4 & 4 & 4 \\
\hline $\begin{array}{l}\text { Valores < } \\
0,01 \mathrm{mg} / \mathrm{L}^{*}\end{array}$ & - & 4 & 3 & 4 & - \\
\hline $\mathrm{N}-\mathrm{NO}_{3}{ }^{-}(\mathrm{mg} / \mathrm{L})$ & $\begin{array}{c}\text { ER2 } \\
\left(\mathrm{N}-\mathrm{NH}_{3}\right)\end{array}$ & SR1 & SR2 & SR3 & $\begin{array}{r}\mathrm{SR3} \\
\left(\mathrm{N}-\mathrm{NH}_{3}\right) \\
\end{array}$ \\
\hline Média & 40,16 & 16,73 & 7,67 & 16,02 & ND \\
\hline Mínimo & 38,24 & 10,93 & 2,82 & 10,97 & ND \\
\hline Máximo & 41,26 & 24,14 & 12,07 & 22,75 & 0,29 \\
\hline $\mathbf{n}$ & 4 & 4 & 4 & 4 & 4 \\
\hline
\end{tabular}

(*) Esse valor não é o limite de detecção do método. 
Tabela 5.21 - Valores mínimo, máximo, média aritmética e número de amostras analisadas para os parâmetros $\left(\mathrm{N}^{-} \mathrm{NO}_{2}^{-}\right)$e $\left(\mathrm{N}^{-\mathrm{NO}_{3}}{ }^{-}\right)$e número de amostras com concentração de nitrito menor que $0,01 \mathrm{mg} / \mathrm{L}$ encontrados na etapa III, sequência II.

\begin{tabular}{|c|c|c|c|c|c|}
\hline \multirow{2}{*}{$\begin{array}{l}\mathrm{N}-\mathrm{NO}_{2}{ }^{-} \\
(\mathrm{mg} / \mathrm{L})\end{array}$} & \multicolumn{5}{|c|}{ Etapa III } \\
\hline & $\begin{array}{c}\text { ER2 } \\
\left(\mathrm{N}-\mathrm{NH}_{3}\right)\end{array}$ & SR1 & SR2 & SR3 & $\begin{array}{c}\mathrm{SR3} \\
\left(\mathrm{N}-\mathrm{NH}_{3}\right)\end{array}$ \\
\hline Média & 33,74 & 0,0035 & 0,0171 & 0,0026 & 0,16 \\
\hline Mínimo & 27,76 & 0,0017 & 0,0025 & 0,0015 & ND \\
\hline Máximo & 39,27 & 0,0092 & 0,0547 & 0,0034 & 0,49 \\
\hline $\mathbf{n}$ & 6 & 6 & 6 & 6 & 6 \\
\hline $\begin{array}{l}\text { Valores < } \\
0,01 \mathrm{mg} / \mathrm{L}^{*}\end{array}$ & - & 6 & 3 & 6 & - \\
\hline $\begin{array}{l}\mathrm{N}-\mathrm{NO}_{3}{ }^{-} \\
(\mathrm{mg} / \mathrm{L})\end{array}$ & $\begin{array}{c}\text { ER2 } \\
\left(\mathrm{N}-\mathrm{NH}_{3}\right)\end{array}$ & SR1 & SR2 & SR3 & $\begin{array}{c}\mathrm{SR3} \\
\left(\mathrm{N}-\mathrm{NH}_{3}\right)\end{array}$ \\
\hline Média & 33,74 & 8,67 & ND & 9,72 & 0,16 \\
\hline Mínimo & 27,76 & 5,59 & ND & 4,57 & ND \\
\hline Máximo & 39,27 & 14,07 & 0,01 & 21,00 & 0,49 \\
\hline $\mathbf{n}$ & 6 & 6 & 6 & 6 & 6 \\
\hline
\end{tabular}

(*) Esse valor não é o limite de detecção do método.

Um aumento significativo no potencial de desnitrificação do sistema foi observado com o mudança na razão de recirculação $R_{c}$ de 1 para 2,65, efetuada da etapa

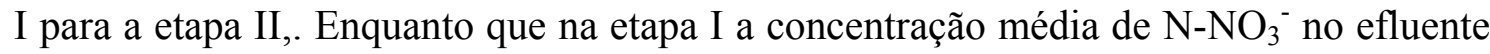
do sistema era igual a $22,6 \mathrm{mg} / \mathrm{L}$, para concentração média de $\mathrm{N}-\mathrm{NH}_{3}$ no afluente de $34,2 \mathrm{mg} / \mathrm{L}$, a concentração média no efluente do sistema na etapa II, foi igual a 16,02 mg N-NO ${ }_{3} / \mathrm{L}$ - para concentração média de $\mathrm{N}^{-N_{3}}$ no afluente igual a 40,16 mg/L (tabelas 5.19 e 5.20).

Pelos dados da tabela 5.21 é possível verificar que o aumento no potencial de desnitrificação do sistema foi ainda mais significativo com a mudança efetuada da etapa II para a etapa III. Para concentração média de $\mathrm{N}^{-N_{3}}$ igual 33,74 mg/L no afluente ao

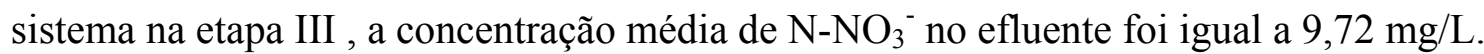

Para melhor visualização da evolução do potencial de desnitrificação ao longo da seqüência II em todas as etapas, um gráfico tipo box-plot foi elaborado considerando os dados referentes às concentrações de $\mathrm{N}_{-} \mathrm{NH}_{3}$ no afluente e no efluente, respectivamente, e $\mathrm{N}^{-\mathrm{NO}_{3}}{ }^{-}$no efluente do sistema (figura 5.26). 


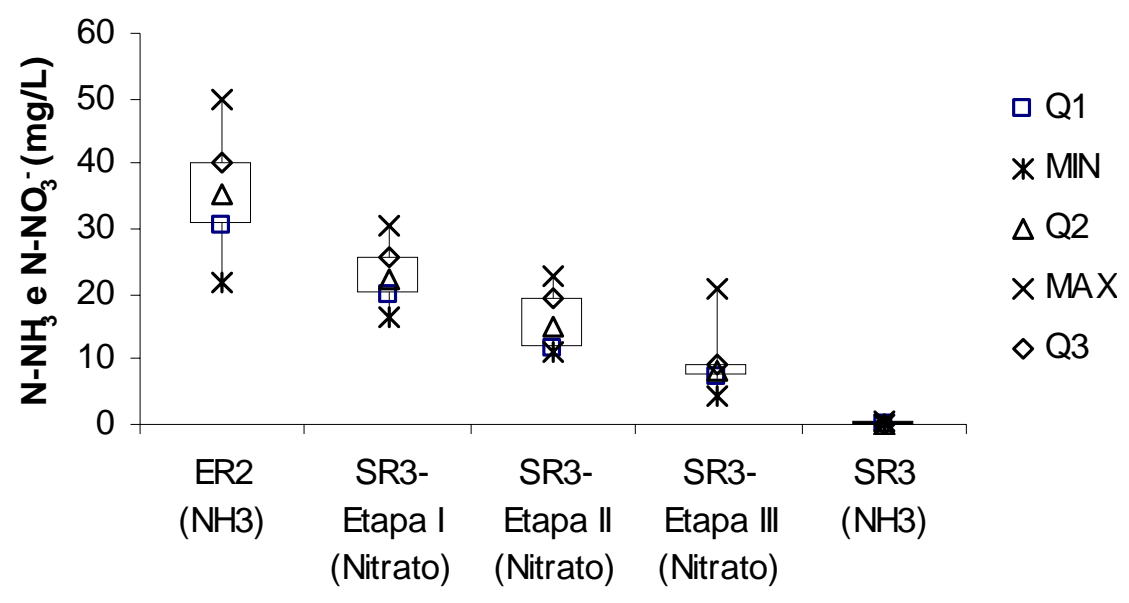

\section{Amostras}

Figura 5.26 - Evolução do potencial de desnitrificação ao longo das etapas da seq. II.

Pela figura 5.26 é possível observar que a concentração de $\mathrm{N}-\mathrm{NH}_{3}$ no afluente ao sistema de reatores operados na seqüência II variou entre 22 e $40 \mathrm{mg} / \mathrm{L}$ em $75 \%$ dos resultados encontrados em todas as etapas investigadas. A figura mostra, ainda, que a concentração efluente de $\mathrm{N}-\mathrm{NH}_{3}$ em todas as etapas da seqüência II esteve próxima a zero evidenciando atividade nitrificante em todo período investigado.

A evolução do aumento do potencial de desnitrificação observado ao longo das etapas de operação também é visível pela análise da figura 5.26. As concentrações de N$\mathrm{NO}_{3}$ no efluente - variaram entre 16 e $26 \mathrm{mg} / \mathrm{L}$ em 75\% das amostras analisadas na etapa I, entre 11 e $20 \mathrm{mg} / \mathrm{L}$ também em $75 \%$ dos resultados obtidos, durante a etapa II, e entre 5 e $9 \mathrm{mg} / \mathrm{L}$ para o esse mesmo percentual de amostras investigadas na etapa III.

O emprego de esgoto bruto como fonte de carbono, na porcentagem de $40 \%$, misturado ao efluente do reator UASB, no total do volume armazenado no reservatório que alimentava o sistema, pode ter sido o fator responsável pelo aumento observado no potencial de desnitrificação do sistema durante a operação da etapa III, seqüência II.

A relação DQO/N observada durante a operação da seqüência II - etapa III evidencia aumento na disponibilidade de fonte de carbono para a desnitrificação heterotrófica. Esse pode ter sido o fator decisivo para o aumento do potencial de conversão de $\mathrm{N}_{-\mathrm{NO}_{3}}{ }^{-}$para $\mathrm{N}_{2}$. O valor da relação DQO/N observado na seqüência I foi em média igual a 2,2, resultando em baixo potencial de desnitrificação, enquanto que esse valor na etapa III, foi em média igual a 26, justificando o maior potencial observado nessa fase. A figura 5.27 apresenta a dispersão dos resultados da relação DQO/N observadas na seqüência I e na etapa III da seqüência II. 


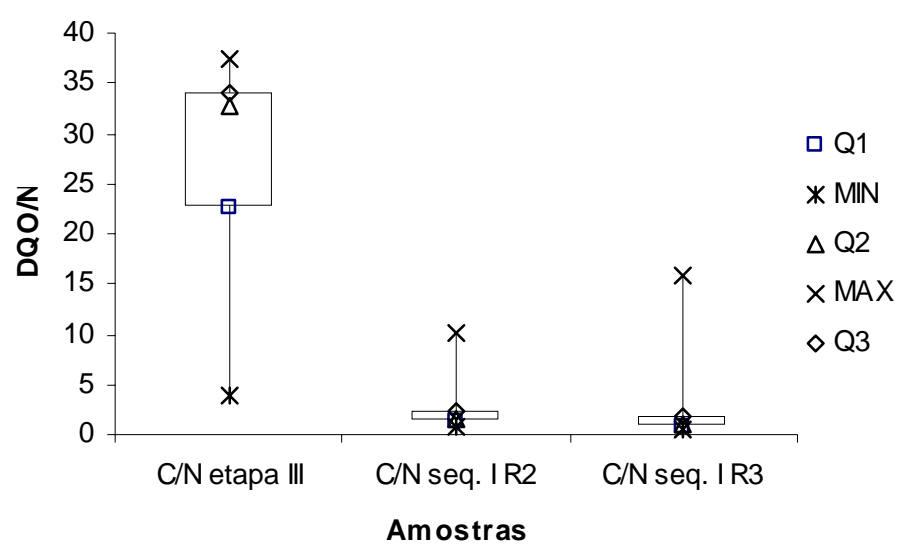

Figura 5.27 - Box-plot das relações DQO/N observadas na seqüência I e na etapa III.

A figura revela que a dispersão dos resultados observados na seqüência I para a relação DQO/N, como discutidos anteriormente, esteve entre 0,7 e 2,4 e 0,4 e 2,2 para $75 \%$ das amostras investigadas nos reatores R2 e R3, respectivamente, enquanto que a dispersão para a mesma percentagem do total de amostras analisadas na etapa III da seqüência II esteve entre 22 e 34. O aumento no valor da relação DQO/N ocorreu devido a recirculação e ao emprego de $40 \%$ em volume de esgoto bruto como fonte de carbono, adotados na operação da etapa III. ANUSHUYA E GUPTA (2008) observaram desnitrificação e metanogênese simultâneas em um reator UASB híbrido utilizando esgoto sintético como fonte de carbono e nitrato como aceptor final de elétrons, objetivando avaliar a biodegradabilidade de um composto fenólico complexo. A relação DQO/N empregada no experimento desses autores variou entre 4,4 e 20,1.

RUIZ et. al (2006) investigaram o potencial de desnitrificação por via curta de um reator UASB, em escala de bancada (3L) e relação DQO/N em média igual a $2,87$. Para concentrações médias de $\mathrm{N}-\mathrm{NO}_{2}{ }^{-}$e de $\mathrm{N}-\mathrm{NO}_{3}{ }^{-}$no afluente ao sistema iguais a 433 e $136 \mathrm{mg} / \mathrm{L}$, respectivamente, as concentrações efluentes foram em média iguais a 0,6 $\mathrm{mg}$ de nitrito/L e $2 \mathrm{mg}$ de nitrato/L, revelando alto pontecial do sistema na desnitrificação via curta.

$\mathrm{O}$ aumento na razão de recirculação $\mathrm{R}_{\mathrm{c}}$ de 1 para 2,65 também contribuiu para melhoria dos resultados referentes ao aumento da desnitrificação investigada na seqüência II. Essa melhoria é evidenciada, também, pelos dados apresentados na figura 5.26, na qual é possível avaliar a variação das concentrações, no efluente do sistema, registradas a partir da mudança da etapa I para a etapa II. RAMOS et. al (2007) investigaram o potencial remoção de um biofiltro na remoção de nitrogênio e fenol de 
efluente industrial aplicando valores de $\mathrm{R}_{\mathrm{c}}$ de 3,4 e 6 . Esses autores verificaram eficiência máxima de $63 \%$ na oxidação de $\mathrm{N}_{-} \mathrm{NH}_{3}$ a N-NO${ }_{3}{ }^{-}$durante seu experimento.

Os resultados referentes à alcalinidade total, encontrada na seqüência II, etapas I, II e III, estão apresentados nas tabelas 5.22 a 5.24 e contribuíram para discussão complementar sobre o potencial do sistema quanto à nitrificação e desnitrificação, respectivamente.

Tabela 5.22 - Valores, mínimo, máximo, média aritmética e número de amostras analisadas para as variáveis $\mathrm{pH}$ e alcalinidade total em $\mathrm{mg}$ de $\mathrm{CaCO}_{3} / \mathrm{L}$ analisados na etapa I, sequência II.

\begin{tabular}{|c|c|c|c|c|c|c|c|c|c|}
\hline \multirow{2}{*}{$\begin{array}{l}\text { Alcal. Tot. } \\
\left(\mathrm{mgCaCO}_{3} / \mathrm{L}\right)\end{array}$} & \multicolumn{4}{|c|}{ Etapa I } & \multirow{2}{*}{ pH } & \multicolumn{4}{|c|}{ Etapa I } \\
\hline & ER1 & SR1 & SR2 & SR3 & & ER1 & SR1 & SR2 & SR3 \\
\hline Méd. & 276 & 68 & 188 & 54 & Méd. & 7,34 & 7,80 & 7,68 & 7,39 \\
\hline Mín. & 224 & 47 & 158 & 9 & Mín. & 6,85 & 7,62 & 7,36 & 6,64 \\
\hline Máx. & 359 & 89 & 230 & 95 & Máx. & 8,17 & 7,89 & 7,93 & 7,69 \\
\hline $\mathbf{n}$ & 9 & 4 & 4 & 9 & $\mathbf{n}$ & 9 & 4 & 4 & 9 \\
\hline
\end{tabular}

Os dados apresentados na tabela 5.22 corroboram com a afirmação de alto potencial para nitrificação observado na etapa I. Para alcalinidade média afluente ao sistema igual a $276 \mathrm{mg} / \mathrm{L}$, a alcalinidade efluente média foi igual a $54 \mathrm{mg} / \mathrm{L}$. Esses resultados evidenciam alto potencial para nitrificação em virtude do consumo de alcalinidade constatado.

$\mathrm{O} \mathrm{pH}$ no efluente dos três reatores operados na etapa I apresentou um pequeno aumento, comparando-os ao $\mathrm{pH}$ no efluente do sistema, como pode ser observado também na tabela 5.22. O pH médio no afluente ao sistema de reatores foi, em média, igual a 7,34, enquanto que os valores do $\mathrm{pH}$ no efluente de cada reator foram em média iguais a 7,8, 7,68 e 7,39 nos pontos de coleta SR1, SR2 e SR3, respectivamente. Esse aumento observado no $\mathrm{pH}$ efluente pode ser atribuído à dessorção de $\mathrm{CO}_{2}$ presente na fase líquida do sistema. Vale lembrar que o sistema proposto nessa pesquisa foi empregado no pós-tratamento de efluente de reator anaeróbio, que pode possuir elevada concentração de $\mathrm{CO}_{2}$ diluído. Essa concentração de $\mathrm{CO}_{2}$ pode ter sido reduzida, por dessorção, no momento em que o efluente anaeróbio entrou em contato com o ambiente 
aerado do sistema, acarretando no aumento do $\mathrm{pH}$ no efluente de cada reator (Van HAANDEL E LETTINGA, $1994^{9}$ apud RODRÍGUEZ, 2006).

A figura 5.28 foi elaborada para melhor compreensão dos resultados apresentados na tabela 5.22 .
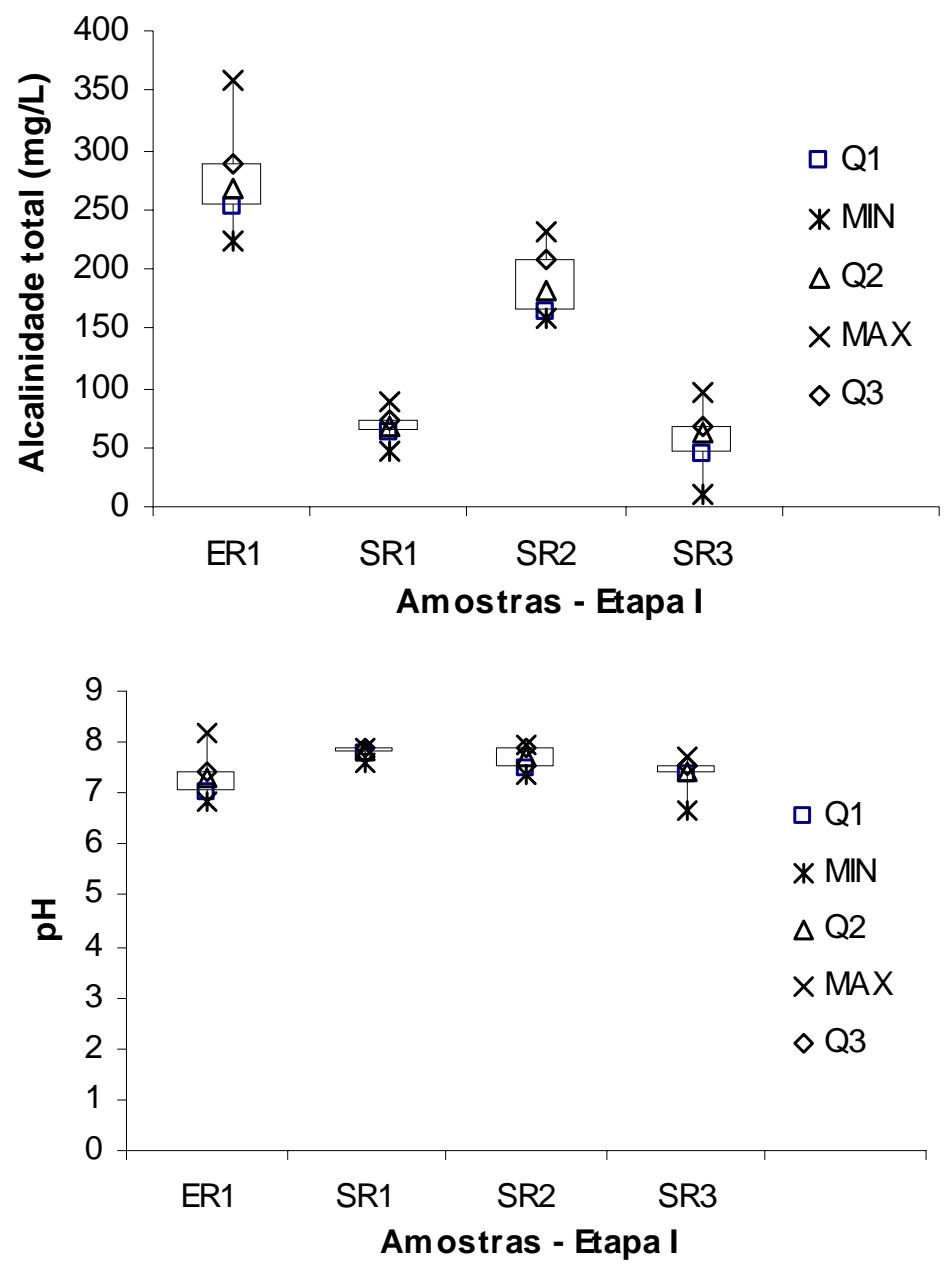

Figura 5.28 - Box-plot dos resultados de pH e alcalinidade total da etapa I, sequência II.

A figura 5.28 revela a dispersão nos dados de entrada e saída do sistema, quanto à variável alcalinidade total. Nos resultados de entrada do sistema, a alcalinidade total variou entre 225 e $290 \mathrm{mg}$ de $\mathrm{CaCO}_{3}{ }^{-} / \mathrm{L}$ em $75 \%$ das amostras investigadas. A dispersão observada nos dados de saída revelou variação da alcalinidade efluente do sistema entre 9 e $66 \mathrm{mg}$ de $\mathrm{CaCO}_{3}{ }^{-} / \mathrm{L}$ para mesma percentagem de amostras investigadas. Essa dispersão pode ser atribuída à atividade nitrificante complementar do reator R3. É

\footnotetext{
${ }^{9}$ Van HAANDEL, A., LETTINGA, G. (1994). Tratamento anaeróbio de esgotos - um manual para regiões de clima quente. Campina Grande - PB. 472p.
} 
possível notar, também, que a dispersão dos resultados de alcalinidade em SR1 foi menor que a observada em SR3. Esse fato pode ser devido à recirculação efetuada entre R1 e R2que atenuava as possíveis variações de alcalinidade encontradas em SR1.

Tabela 5.23 - Valores mínimo, máximo, média aritmética e número de amostras analisadas para as variáveis $\mathrm{pH}$ e alcalinidade total em $\mathrm{mg}$ de $\mathrm{CaCO}_{3} / \mathrm{L}$ analisados na etapa II.

\begin{tabular}{|c|c|c|c|c|c|c|c|c|c|}
\hline \multirow{2}{*}{$\begin{array}{l}\text { Alcal. Tot. } \\
\left(\mathrm{mgCaCO}_{3} / \mathrm{L}\right)\end{array}$} & \multicolumn{4}{|c|}{ Etapa II } & \multirow[b]{2}{*}{ pH } & \multicolumn{4}{|c|}{ Etapa II } \\
\hline & ER1 & SR1 & SR2 & SR3 & & ER1 & SR1 & SR2 & SR3 \\
\hline Méd. & 294 & 99 & 182 & 108 & Méd. & 7,10 & 8,05 & 7,38 & 7,90 \\
\hline Mín. & 261 & 72 & 161 & 90 & Mín. & 6,96 & 7,87 & 7,19 & 7,82 \\
\hline Máx. & 344 & 145 & 223 & 150 & Máx. & 7,28 & 8,22 & 7,48 & 8 \\
\hline $\mathbf{n}$ & 4 & 4 & 4 & 4 & $\mathbf{n}$ & 4 & 4 & 4 & 4 \\
\hline
\end{tabular}

$\mathrm{Na}$ etapa II a alcalinidade média no afluente ao sistema foi igual a $294 \mathrm{mg}$ de $\mathrm{CaCO}_{3} / \mathrm{L}$, valor esse muito próximo ao observado durante a operação da etapa $\mathrm{I}$ (Tabela 5.22). Porém, o valor da alcalinidade efluente média na etapa II, igual a $108 \mathrm{mg}$ $\mathrm{CaCO}_{3} / \mathrm{L}$, foi superior ao valor observado durante a etapa I. Esse resultado pode ser atribuído ao aumento no potencial de desnitrificação, observado na etapa II, devido à mudança da razão de recirculação, $\mathrm{R}_{c}$, para 2,65.

$\mathrm{O}$ aumento no valor do $\mathrm{pH}$ efluente de cada reator operado durante a etapa II, também foi constatado como mostra os resultados apresentados na tabela 5.23. A justificativa para tal aumento pode ser a mesma apontada para os resultados de $\mathrm{pH}$ encontrados na etapa I, ou seja, dessorção de $\mathrm{CO}_{2}$ presente na fase líquida do sistema.

Para melhor visualização da dispersão dos resultados encontrados na etapa II, um gráfico tipo box-plot foi elaborado conforme representado na figura 5.29. 

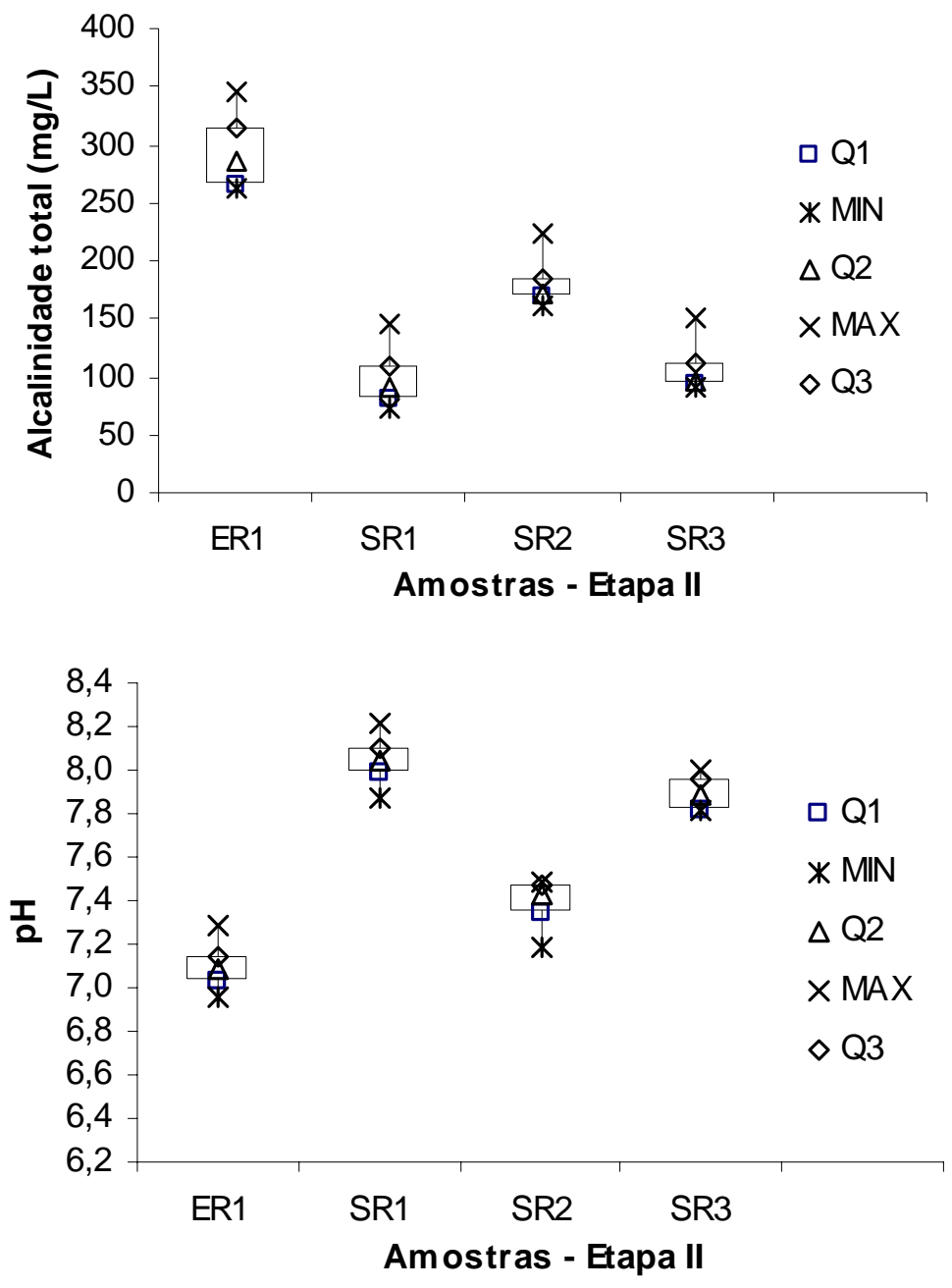

Figura 5.29 - Box-plot dos resultados de pH e alcalinidade total da etapa II.

Pela figura 5.29 é possível observar que a alcalinidade afluente ao sistema de reatores da etapa II variou entre 260 e $315 \mathrm{mg} \mathrm{CaCO}_{3} / \mathrm{L}$ em $75 \%$ das amostras investigadas. A atividade nitrificante pode ser verificada pela diminuição da alcalinidade efluente do sistema que variou entre 90 e $110 \mathrm{mg} \mathrm{CaCO}_{3} / \mathrm{L}$, para mesma percentagem de amostras analisadas. Esses resultados também corroboram com a afirmação feita sobre o aumento do potencial de desnitrificação verificado na etapa II com o aumento do valor de $\mathrm{R}_{\mathrm{c}}$.

$\mathrm{O}$ aumento no $\mathrm{pH}$ efluente dos reatores, também é melhor visualizado pelas dispersões apresentadas na figura 5.29. O pH afluente ao sistema, em 75\% das amostras investigadas na etapa II, variou entre 7 e 7,3 enquanto que os valores dos $\mathrm{pH}$ efluentes dos reatores R1, R2 e R3 variaram entre 8 e 8,$2 ; 7,3$ e 7,5 e 7,8 e 8, respectivamente, para a mesma percentagem de amostras investigadas. 
$\mathrm{Na}$ etapa III a alcalinidade total afluente ao sistema de reatores, em média, foi menor que as encontradas nas etapas I e II, respectivamente. A alcalinidade total média afluente ao sistema foi igual a $199 \mathrm{mg} \mathrm{CaCO}_{3} / \mathrm{L}$ enquanto que a efluente média observada foi igual a $48 \mathrm{mg} \mathrm{CaCO}_{3} / \mathrm{L}$ (Tabela 5.24). Esses resultados evidenciam o alto potencial em nitrificação observado, também, nessa etapa.

$\mathrm{O}$ valor de $\mathrm{pH}$ efluente dos reatores operados durante a etapa III, também, se comportou como os observados nas etapas I e IIcomo pode ser constato pelos resultados apresentados na tabela 5.24.

Tabela 5.24 - Valores, mínimo, máximo, média aritmética e número de amostras analisadas para os parâmetros $\mathrm{pH}$ e alcalinidade total em $\mathrm{mg}$ de $\mathrm{CaCO}_{3} / \mathrm{L}$ analisados na etapa III.

\begin{tabular}{|c|c|c|c|c|c|c|c|c|c|}
\hline \multirow{2}{*}{$\begin{array}{c}\text { Alcal. Tot. } \\
\left(\mathrm{mgCaCO}_{3} / \mathrm{L}\right)\end{array}$} & \multicolumn{4}{|c|}{ Etapa III } & \multirow[b]{2}{*}{$\mathbf{p H}$} & \multicolumn{4}{|c|}{ Etapa III } \\
\hline & ER1 & SR1 & SR2 & SR3 & & ER1 & SR1 & SR2 & SR3 \\
\hline Méd. & 199 & 54 & 96 & 48 & Méd. & 6,84 & 7,36 & 7,32 & 7,33 \\
\hline Mín. & 178 & 3 & 32 & 4 & Mín. & 6,5 & 6,1 & 7,02 & 6,12 \\
\hline Máx. & 257 & 103 & 153 & 120 & Máx. & 7,22 & 8,02 & 7,65 & 8,01 \\
\hline $\mathbf{n}$ & 6 & 6 & 6 & 6 & $\mathbf{n}$ & 6 & 6 & 6 & 6 \\
\hline
\end{tabular}

A figura 5.30 apresenta a dispersão dos resultados encontrados na etapa III, para os parâmetros alcalinidade e $\mathrm{pH}$.

A alcalinidade total afluente ao sistema na etapa III variou entre 177 e $200 \mathrm{mg}$ $\mathrm{CaCO}_{3} / \mathrm{L}$ em $75 \%$ das amostras investigadas evidenciando queda no valor dessa variável em relação aos dados de entrada das etapas I e II, respectivamente. Essa queda pode ser atribuída à adição de esgoto bruto efetuada no reservatório de entrada, para ser utilizado como fonte de carbono para desnitrificação.

O ensaio para determinação da quantidade de alcalinizante necessário, para a nova composição de esgoto afluente ao sistema, não foi realizado nessa etapa. Assim, a quantidade de alcalinizante que vinha sendo adicionada pode não ter sido suficiente para manter os valores de alcalinidade afluente dentro das faixas de variação observadas nas etapas I e II, respectivamente. 


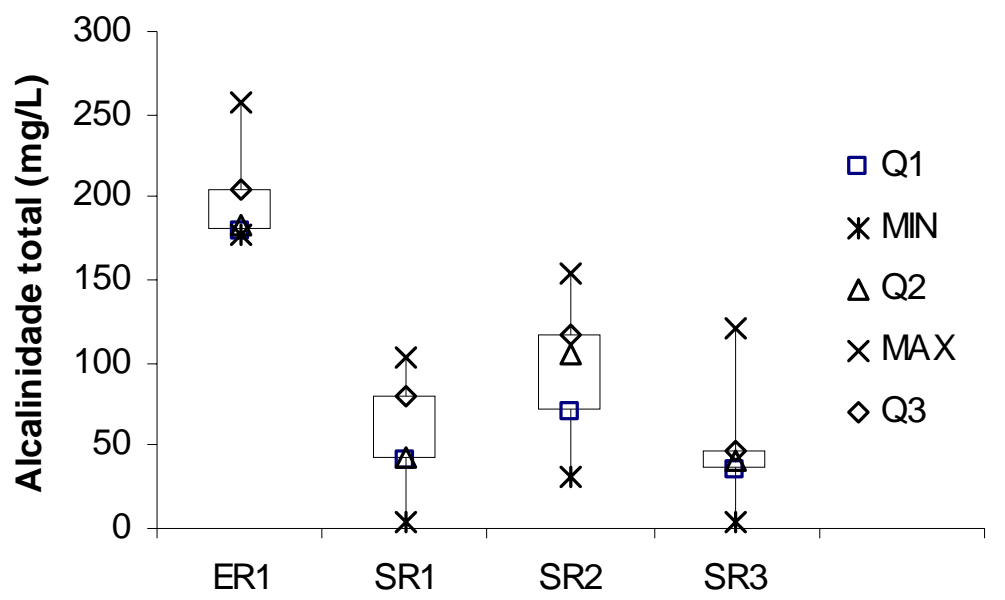

Amostras - Etapa III

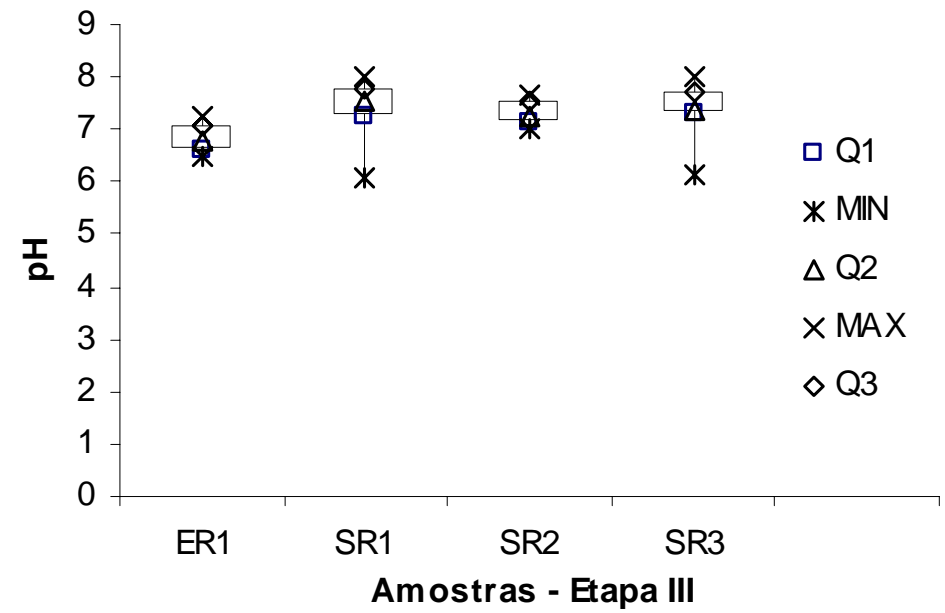

Figura 5.30 - Box-plot dos resultados de pH e alcalinidade total da etapa III.

Pela análise da figura 5.30 é possível notar que a alcalinidade efluente do sistema variou entre 35 e $120 \mathrm{mg} \mathrm{CaCO}_{3} / \mathrm{L}$ revelando a dispersão dos resultados encontrados em $75 \%$ das amostras investigadas. A atividade nitrificante do sistema, na etapa III, que implicava no consumo de alcalinidade, é constatada pela faixa de variação observada em $50 \%$ das amostras analisadas que esteve entre 35 e $47 \mathrm{mg} \mathrm{CaCO}_{3} / \mathrm{L}$. A dispersão observada nos resultados em SR3 pode ser atribuída à questão da mudança efetuada na composição do esgoto armazenado, mencionada anteriormente.

Essa questão da alteração da composição do esgoto armazenado não afetou significativamente os valores do $\mathrm{pH}$ efluente de cada reator operado na etapa III, como é possível observar nas dispersões dos resultados de SR1 e SR3 apresentados na figura 5.30 . 


\subsection{Biofiltro Piloto.}

\subsubsection{Remoção de DQO}

As maiores DQO no afluente foram observadas durante a operação do Biofiltro Piloto. Pela tabela 5.25 é possível observar que a DQO máxima no afluente ao sistema observada nessa fase da pesquisa foi de $963 \mathrm{mg} / \mathrm{L}$ de DQO. A tabela 5.25 mostra, ainda, que a eficiência média de remoção de DQO alcançada pelo sistema durante a operação do Biofiltro Piloto foi de 79,2\%. Em média, essa eficiência de remoção foi maior que a observada durante a operação da seqüência I cujo valor foi de 68,4\% (tabela 5.3).

Tabela 5.25 - Valores mínimo, máximo, média aritmética de DQO, COVa e COVr das amostras analisadas na operação do Biofiltro Piloto.

\begin{tabular}{c|ccccc}
\hline $\begin{array}{c}\text { DQO } \\
\text { (Biofiltro Piloto) }\end{array}$ & ER2 & SR3 & $\begin{array}{l}\text { Eficiência } \\
\mathbf{( \% )}\end{array}$ & $\begin{array}{c}\text { COVa } \\
\left(\mathbf{k g D Q O} / \mathbf{m}^{3} \mathbf{d}\right)\end{array}$ & $\begin{array}{c}\text { COVr } \\
\left(\mathbf{k g D Q O} / \mathbf{m}^{3} \mathbf{d}\right)\end{array}$ \\
\hline Média & 294,1 & 31,5 & 79,2 & 0,50 & 0,45 \\
Mínimo & 51,0 & 20,0 & 49,0 & 0,09 & 0,05 \\
Máximo & 963,0 & 61,0 & 97,4 & 1,64 & 1,58 \\
$\mathbf{n}$ & 12 & 12 & 12 & 12 & 12 \\
\hline
\end{tabular}

A tabela 5.25 mostra, também, que as carga volumétricas aplicada (COVa) e removida (COVr) em DQO foram em média, respectivamente, iguais a $0,50 \mathrm{~kg}$ de $\mathrm{DQO} / \mathrm{m}^{3} \mathrm{~d}$ e $0,45 \mathrm{~kg}$ de $\mathrm{DQO} / \mathrm{m}^{3} \mathrm{~d}$ revelando alto potencial do sistema na remoção dessa variável durante a operação do BF.

A correlação entre as cargas volumétricas aplicadas e removidas de DQO pelo sistema durante a operação do BF está representada na figura 5.31.

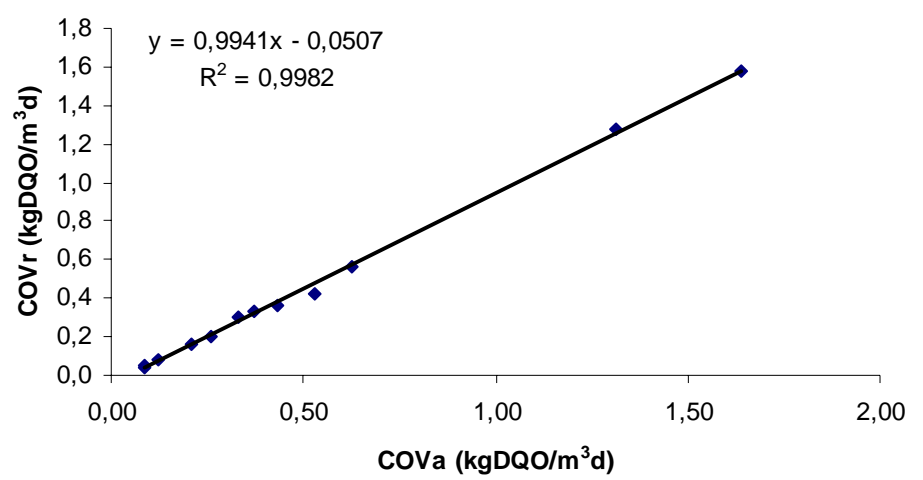

Figura 5.31 - Correlação entre COVa e COVr em DQO para o Biofiltro Piloto. 
A equação da reta ajustada aos pontos do gráfico apresentado na figura 5.30 indica que para COVa igual a $1 \mathrm{~kg}$ de $\mathrm{DQO} / \mathrm{m}^{3} \mathrm{~d}$ o valor de COVr era de $0,95 \mathrm{~kg}$ de $\mathrm{DQO} / \mathrm{m}^{3} \mathrm{~d}$. Esse resultado corrobora a afirmação feita sobre o alto potencial do sistema na remoção de DQO.

A variação temporal da DQO observada durante a operação do Biofiltro Piloto está apresentada na figura 5.32.

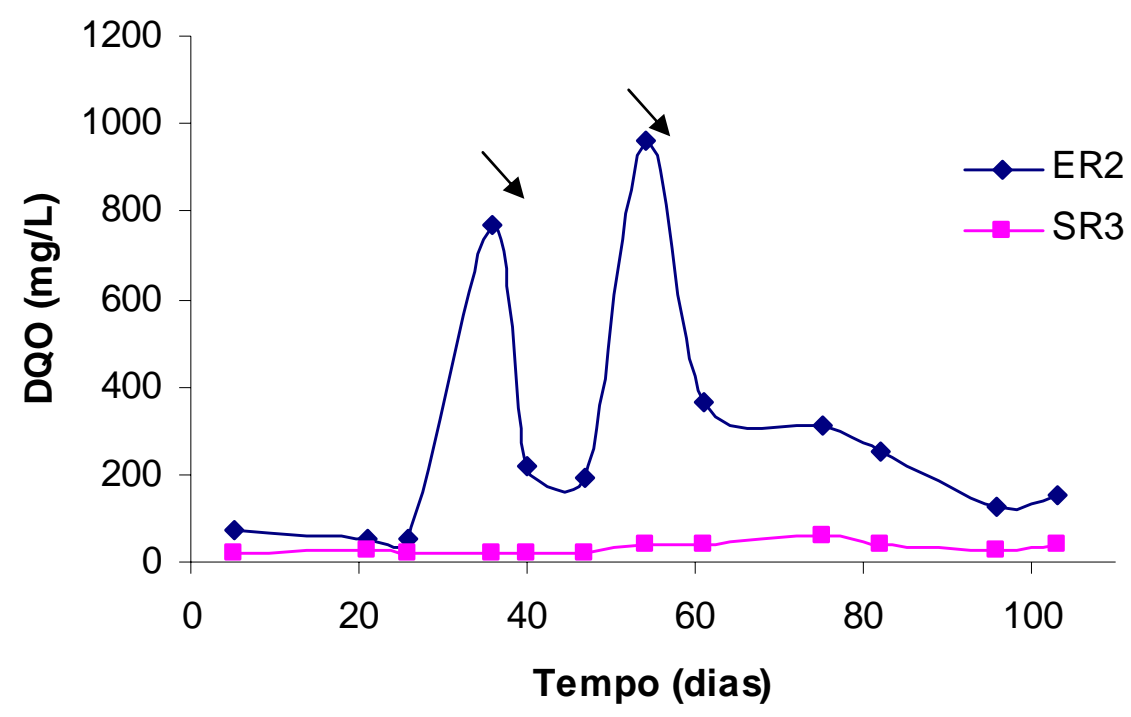

Figura 5.32 - Variação temporal da DQO durante a operação do Biofiltro Piloto.

Pela figura 5.32 é possível constatar a considerável resistência do sistema em suportar sobrecargas em DQO. Os picos, indicados pelas setas, mostram que para as concentrações afluentes iguais a 772 e $963 \mathrm{mg} / \mathrm{L}$ as concentrações efluentes foram iguais a 20 e $36 \mathrm{mg} / \mathrm{L}$, respectivamente. Esses picos nas concentrações afluentes ao sistema, são reflexos do desempenho do reator UASB que foi totalmente comprometido nessa fase da pesquisa, por estar sendo objeto da investigação de outros pesquisadores que alteraram todas as condições de operação que este possuía até o início da operação do Biofiltro Piloto.

\subsubsection{Remoção de Nitrogênio}

Os resultados referentes à conversão de NTK na operação do Biofiltro Piloto estão apresentados na tabela 5.26 que ilustra os valores mínimo, máximo, média aritmética e eficiência total de conversão para as amostras analisadas. 
Tabela 5.26 - Valores mínimo, máximo, média aritmética e eficiência total do sistema na conversão de NTK para amostras analisadas, na operação do Biofiltro Piloto.

\begin{tabular}{c|ccc}
\hline $\begin{array}{c}\text { NTK (Biofiltro } \\
\text { Piloto) }\end{array}$ & $\begin{array}{c}\text { Afluente } \\
\text { (mg/L) }\end{array}$ & $\begin{array}{c}\text { Efluente } \\
\text { (mg/L) }\end{array}$ & $\begin{array}{c}\text { Efic. } \\
\text { Total. } \\
\text { (\%) }\end{array}$ \\
\cline { 2 - 3 } & ER2 & SR3 & (\%) \\
\hline Média & 49,9 & 22,1 & 56,0 \\
Mínimo & 30,5 & 4,2 & 11,6 \\
Máximo & 82,1 & 40,1 & 86,8 \\
$\mathbf{n}$ & 12,0 & 12,0 & 12,0 \\
\hline
\end{tabular}

A tabela 5.26 revela que a concentração média afluente em NTK ao sistema do Biofiltro Piloto foi em média igual a $49,9 \mathrm{mg} / \mathrm{L}$ enquanto que a média efluente observada foi igual a $22,1 \mathrm{mg} / \mathrm{L}$ indicando eficiência média de conversão igual a $56 \%$.

A figura 5.33 apresenta a dispersão dos resultados encontrados na operação do Biofiltro Piloto.

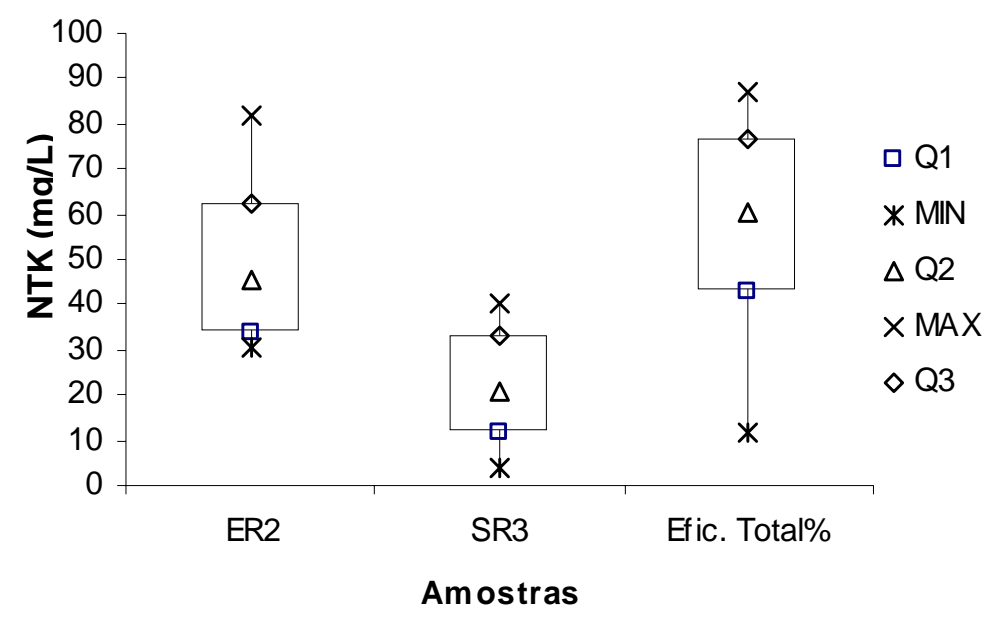

Figura 5.33 - Box-plot do parâmetro NTK para resultados obtidos na operação do Biofiltro Piloto.

Pela figura 5.33, é possível verificar que a concentração de NTK no afluente variou entre 34 e $82 \mathrm{mg} / \mathrm{L}$ em 75\% do total de amostras analisadas, enquanto que para essa mesma percentagem, a concentração efluente esteve entre 11 e $40 \mathrm{mg} / \mathrm{L}$. A grande dispersão observada nesses resultados reflete a instabilidade operacional do sistema. Tal instabilidade, como mencionada no capítulo 4, foi proporcionada pela quebra dos compressores e obstrução da válvula de pé com crivo da bomba que alimentava o sistema causando variações no valor da vazão afluente aos reatores do Biofiltro Piloto. 
Outro fator, também apontado anteriormente, foi a questão da utilização do UASB como objeto de investigação de outros pesquisadores, que incorreu na alteração das características do efluente produzido pelo mesmo.

A tabela 5.27 apresenta os valores mínimo, máximo, média aritmética e eficiência total de conversão para as amostras analisadas na operação do Biofiltro Piloto para a variável $\mathrm{N}-\mathrm{NH}_{3}$

Tabela 5.27 - Valores mínimo, máximo, média aritmética e eficiência total do sistema na conversão de $\mathrm{N}-\mathrm{NH}_{3}$ para amostras analisadas, na operação do Biofiltro Piloto.

\begin{tabular}{c|ccc}
\hline $\begin{array}{c}\mathbf{N}^{\mathbf{N H}} \mathbf{N}_{3} \\
\text { (Biofiltro Piloto) }\end{array}$ & $\begin{array}{c}\text { Afluente } \\
\text { (mg/L) }\end{array}$ & $\begin{array}{c}\text { Efluente } \\
\text { (mg/L) }\end{array}$ & $\begin{array}{c}\text { Efic. } \\
\text { Total. } \\
\text { (\%) }\end{array}$ \\
\hline Média & 37,8 & 13,4 & 67,3 \\
Mínimo & 22,4 & N.D & 27,1 \\
Máximo & 52,0 & 37,9 & 100,0 \\
$\mathbf{n}$ & 12,0 & 12,0 & 12,0 \\
Valor $<\mathbf{0 , 1}$ & - & 1 & - \\
\hline
\end{tabular}

Pela tabela 5.27 é possível verificar que o potencial de conversão de $\mathrm{N}_{-} \mathrm{NH}_{3}$ também foi prejudicado pela instabilidade operacional observada na operação do Biofiltro Piloto, pelos mesmos motivos justificados para o parâmetro NTK. Para concentração média afluente ao sistema igual a $37,8 \mathrm{mg} / \mathrm{L}$ a concentração média efluente foi igual a $13,4 \mathrm{mg} / \mathrm{L}$ revelando eficiência média total na conversão de $\mathrm{N}^{-\mathrm{NH}_{3}}$ de $67,3 \%$. A figura 5.34 ilustra a dispersão dos resultados referentes a $\mathrm{N}^{-\mathrm{NH}_{3}}$ para melhor interpretação dos dados apresentados na tabela 5.27.

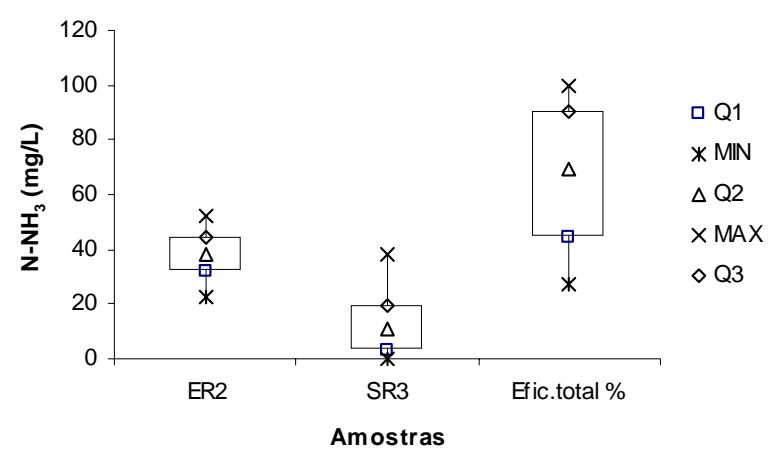

Figura 5.34 - Box-plot do parâmetro $\mathrm{N}-\mathrm{NH}_{3}$ para resultados obtidos na operação do Biofiltro Piloto. 
A concentração de $\mathrm{N}^{-N_{3}}$ afluente ao Biofiltro Piloto variou entre 32 e $52 \mathrm{mg} / \mathrm{L}$ em $75 \%$ das amostras analisadas, enquanto que para esse mesmo percentual, a concentração efluente esteve entre 3,5 e $38 \mathrm{mg} / \mathrm{L}$. A eficiência total de conversão observada nessa fase variou entre 45 e 100\%. A dispersão observada nesses resultados, também revela a instabilidade operacional encontrada nessa fase da pesquisa pelos motivos apontados anteriormente.

O potencial de conversão de $\mathrm{N}-\mathrm{NH}_{3}$ a $\mathrm{N}_{-} \mathrm{NO}_{2}{ }^{-}$e $\mathrm{N}_{-} \mathrm{NO}_{3}{ }^{-}$pode ser interpretado, também, pelos resultados apresentados na tabela 5.28 que apresenta os valores máximo, mínimo e média aritmética das concentrações, para os parâmetros nitrito e nitrato, detectadas na operação do Biofiltro Piloto.

Tabela 5.28 - Valores médio, mínimo, máximo e números de amostras analisadas para os parâmetros $\mathrm{N}_{-} \mathrm{NO}_{2}{ }^{-}$e N-NO${ }_{3}^{-}$encontrados durante a operação do Biofiltro Piloto.

\begin{tabular}{|c|c|c|c|c|c|c|}
\hline \multirow{2}{*}{$\begin{array}{c}\text { (Biofiltro } \\
\text { Piloto) }\end{array}$} & \multicolumn{2}{|c|}{ Nitrito $\left(\mathrm{NO}_{2}^{-}\right)$} & \multicolumn{2}{|c|}{ Nitrato $\left(\mathrm{NO}_{3}{ }^{-}\right)$} & \multicolumn{2}{|c|}{$\mathrm{N}-\mathrm{NH}_{3}$} \\
\hline & $\begin{array}{c}\text { Afluente } \\
\text { (mg/L) } \\
\text { ER2 }\end{array}$ & $\begin{array}{c}\text { Efluente } \\
\text { (mg/L) } \\
\text { SR3 }\end{array}$ & $\begin{array}{c}\text { Afluente } \\
\text { (mg/L) } \\
\text { ER2 }\end{array}$ & $\begin{array}{c}\text { Efluente } \\
\text { (mg/L) } \\
\text { SR3 }\end{array}$ & $\begin{array}{c}\text { Afluente } \\
\text { (mg/L) } \\
\text { ER2 }\end{array}$ & $\begin{array}{c}\text { Efluente } \\
\text { (mg/L) } \\
\text { SR3 }\end{array}$ \\
\hline Média & 0,004 & 0,164 & 0,84 & 14,01 & 37,8 & 13,4 \\
\hline Mínimo & N.D & 0,005 & 0,23 & 1,89 & 22,4 & N.D \\
\hline Máximo & 0,010 & 0,741 & 1,42 & 24,87 & 52,0 & 37,9 \\
\hline $\mathbf{n}$ & 12 & 12 & 12 & 12 & 12 & 12 \\
\hline
\end{tabular}

O sistema operado na configuração do Biofiltro Piloto não apresentou o mesmo potencial de nitrificação como observado na operação das seqüências I e II, respectivamente, como é possível constatar com os resultados apresentados na tabela 5.28. As concentrações de $\mathrm{N}-\mathrm{NH}_{3}$ afluente e efluente ao sistema, respectivamente, foram em média, como já mencionadas, $37,8 \mathrm{mg} / \mathrm{L}$ e $13,4 \mathrm{mg} / \mathrm{L}$. Na operação das configurações dos BFs seqüenciais, a concentração efluente em $\mathrm{N}-\mathrm{NH}_{3}$ durante todo o período de investigação esteve próxima a zero, indicando alto potencial em nitrificação, como discutido anterirmente. A concentração média de $\mathrm{N}-\mathrm{NH}_{3}$ no efluente observada na operação do Biofiltro Piloto indica que nem toda carga nitrogenada estava sendo convertida a $\mathrm{N}-\mathrm{NO}_{3}{ }^{-}$. 
O potencial de desnitrificação alcançado na operação do Biofiltro Piloto foi bem menor que o observado na etapa III da seqüência II, como revelam os dados

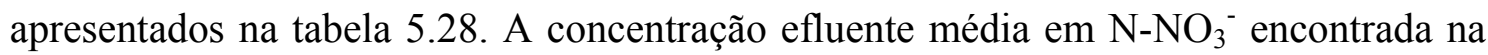
operação do Biofiltro Piloto foi igual a $14,01 \mathrm{mg} / \mathrm{L}$. Comparando esse valor com as concentrações médias afluentes e efluentes em $\mathrm{N}-\mathrm{NH}_{3}$, respectivamente, é possível avaliar o baixo potencial em desnitrificação observado nessa fase da pesquisa.

A figura 5.35 apresenta a dispersão dos resultados apresentados na tabela 5.28 para sua melhor interpretação.

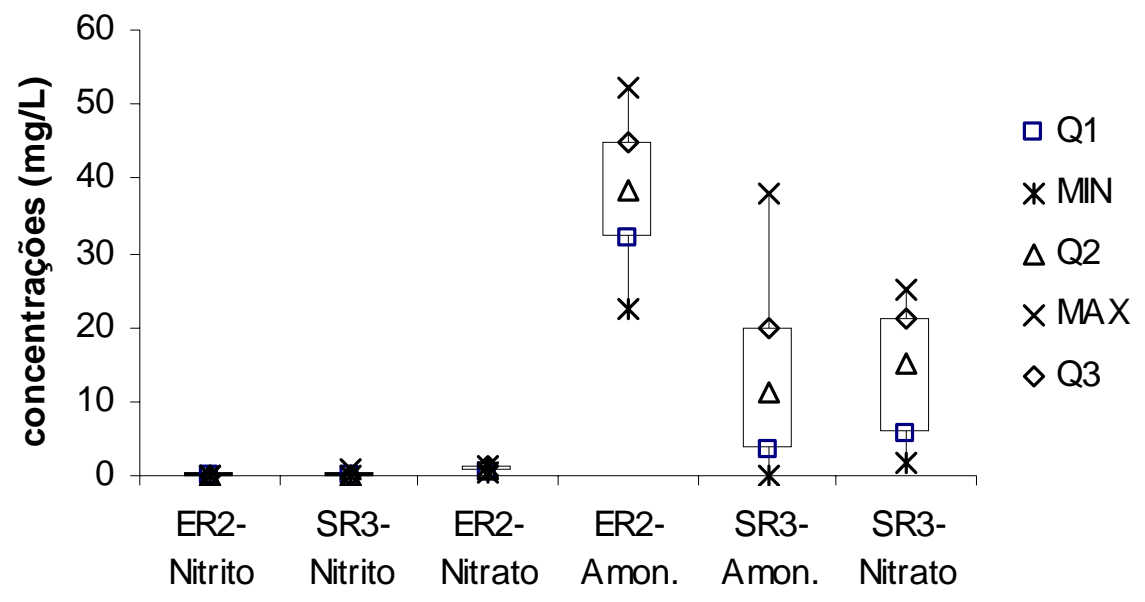

Amostras

Figura 5.35 - Box-plot dos parâmetros $\mathrm{N}-\mathrm{NH}_{3}, \mathrm{~N}_{-} \mathrm{NO}_{2}{ }^{-}$e $\mathrm{N}_{-\mathrm{NO}_{3}}{ }^{-}$obtidos na operação do Biofiltro Piloto.

A dispersão dos resultados das concentrações efluentes em N-NH $\mathrm{NO}_{3}{ }^{-}$, também, apontam para o baixo potencial de nitrificação, observado na operação do Biofiltro Piloto. A concentração de $\mathrm{N}_{-} \mathrm{NH}_{3}$ no afluente em variou entre 32 e $52 \mathrm{mg} / \mathrm{L}$ em $75 \%$ das amostras analisadas, enquanto que as concentrações efluentes em $\mathrm{N}_{-} \mathrm{NH}_{3}$, $\mathrm{N}-\mathrm{NO}_{2}{ }^{-}$e $\mathrm{N}-\mathrm{NO}_{3}{ }^{-}$, variaram respectivamente, entre 3,5 e $38,0,03$ e $0,74,5,5$ e $25 \mathrm{mg} / \mathrm{L}$, para o percentual amostral. O baixo potencial de nitrificação observado no Biofiltro Piloto pode ser atribuído aos problemas no sistema de aeração ocorridos durante a operação do sistema. Em duas ocasiões o compressor que alimentava o BF quebrou e o sistema ficou em média quatro dias sem aeração até que fosse reparado.

A dispersão das concentrações efluentes em $\mathrm{N}-\mathrm{NH}_{3}$ e $\mathrm{N}_{-} \mathrm{NO}_{3}{ }^{-}$, apresentadas na figura 5.35, para 75\% das amostras analisadas, também evidenciam o baixo potencial de desnitrificação observado nessa fase da pesquisa. Além da questão da mudança das 
características do efluente do reator UASB, apontada anteriormente, outra que pode ter contribuído para o baixo potencial de desnitrificação observado na operação do Biofiltro Piloto, foi a quebra da bomba que efetuava recirculação entre os reatores R3 e R2. Essa bomba ficou por dias, aparentemente com funcionamento normal pois o motor estava ligado constantemente, sem que fosse notado que a mesma não estava efetuando a devida recirculação entre os dois reatores do sistema. Nos dez dias finais dessa fase experimental é que esse problema foi detectado e corrigido. Logo a razão de recirculação, $R_{c}$, igual a 2,65 provavelmente não foi mantida durante grande parte do período de análises do Biofiltro Piloto.

Os resultados referentes à alcalinidade total apresentados na tabela 5.29 forneceram suporte para discussão sobre os potenciais de nitrificação e desnitrificação observados durante a operação do Biofiltro Piloto.

Tabela 5.29 - Valores médio, mínimo, máximo e número de amostras analisadas para os parâmetros pH e alcalinidade total analisados na operação do Biofiltro Piloto.

\begin{tabular}{c|cc|cc}
\hline (Biofiltro Piloto) & \multicolumn{2}{|c|}{$\begin{array}{c}\text { Alcalinidade } \\
\left.\text { (mg de } \mathrm{CaCO}_{3} / \mathbf{L}\right)\end{array}$} & \multicolumn{2}{c}{ pH } \\
& Afluente & Efluente & Afluente & Efluente \\
& ER2 & SR3 & ER2 & SR3 \\
& 553 & 198 & 6,73 & 6,59 \\
Média & 19 & 1 & 6,42 & 4,73 \\
Mínimo & 2796 & 1722 & 7,26 & 7,39 \\
Máximo & 12 & 12 & 12 & 12 \\
\hline n & & & & \\
\hline
\end{tabular}

Embora o potencial de nitrificação tenha sido menor que o obtido com os BFs seqüenciais, a atividade nitrificante observada na operação do Biofiltro Piloto é evidenciada pelo consumo de alcalinidade apresentado pelos valores da tabela 5.29. Para alcalinidade média afluente igual a $553 \mathrm{mg} \mathrm{CaCO}_{3} / \mathrm{L}$ a concentração efluente média foi igual a $198 \mathrm{mg} \mathrm{CaCO}_{3} / \mathrm{L}$. A figura 5.36 representa a variação temporal dos valores de alcalinidade total encontrados na operação do Biofiltro Piloto. 


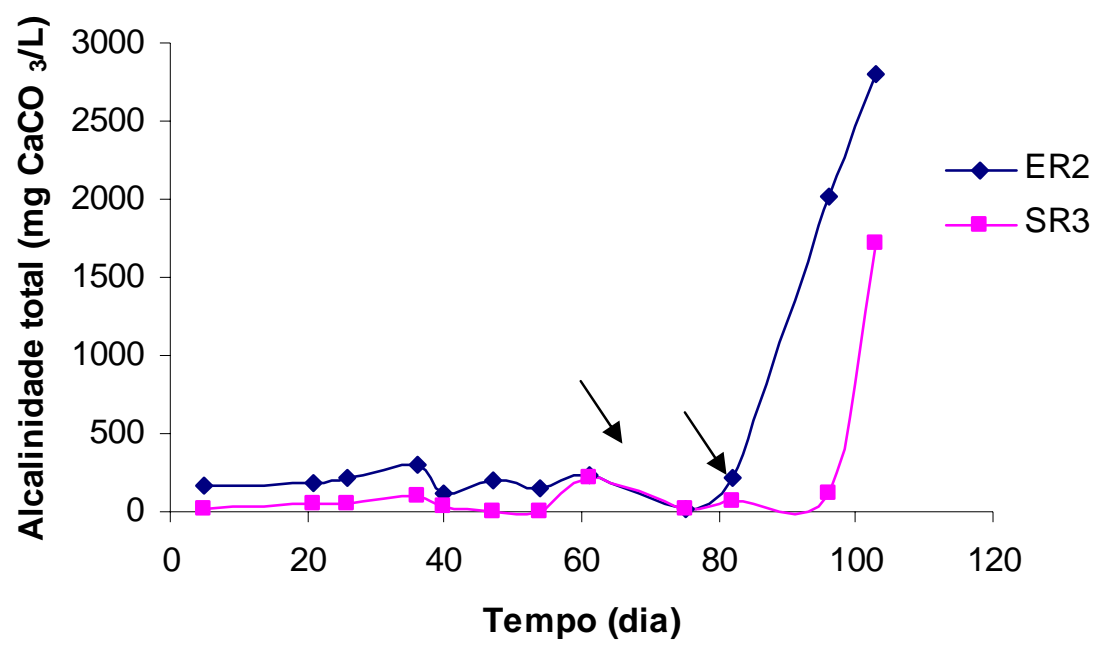

Figura 5.36 - Variação temporal da alcalinidade total durante a operação do Biofiltro

Piloto.

As setas da figura 5.36 indicam os períodos em que ocorreram falhas no sistema de aeração resultando na queda do potencial de nitrificação do sistema. No $60^{\circ}$ dia de operação para alcalinidade total afluente igual a $235 \mathrm{mg}$ de $\mathrm{CaCO}_{3} / \mathrm{L}$ a alcalinidade efluente foi igual a $216 \mathrm{mg} \mathrm{CaCO}_{3} / \mathrm{L}$. No $75^{\circ}$ dia a alcalinidade afluente foi igual a 19 mg de $\mathrm{CaCO}_{3} / \mathrm{L}$ e a efluente igual a $12 \mathrm{mg}$ de $\mathrm{CaCO}_{3} / \mathrm{L}$. Esses valores refletem o impacto na nitrificação causado pela falha do sistema de aeração ocorrida próximo aos períodos indicados na figura 5.36 . O aumento da alcalinidade total afluente e efluente, respectivamente, observado nas últimas semanas de operação do BF, é oriundo das mudanças das características do efluente do reator UASB.

A figura 5.37 apresenta a dispersão dos resultados de alcalinidade total observada na operação do Biofiltro Piloto.

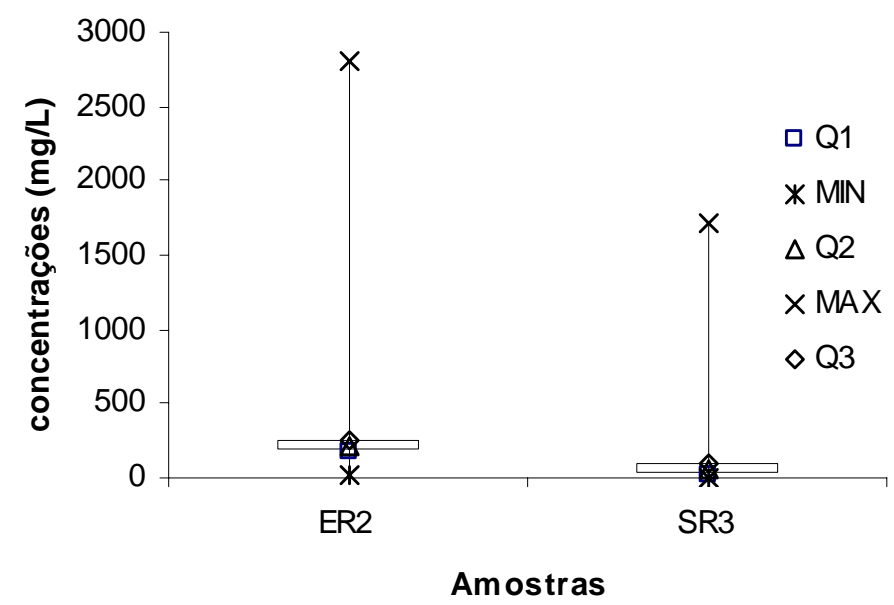

Figura 5.37 - Box-plot dos resultados da alcalinidade total obtidos na operação do Biofiltro Piloto. 
A figura 5.37 revela a dispersão dos resultados de alcalinidade total encontrados na entrada e saída do Biofiltro Piloto. Pela dispersão observada, o valor médio pode oferecer um número bastante representativo dos resultados obtidos para esse parâmetro. $\mathrm{O}$ valor de Q2 para ER2 foi igual a $208 \mathrm{mg}$ de $\mathrm{CaCO}_{3} / \mathrm{L}$ enquanto que para SR3 esse valor foi igual a $50 \mathrm{mg} \mathrm{CaCO}_{3} / \mathrm{L}$.

Devido mudanças ocorridas nas características do efluente do reator UASB, a quantidade de alcalinizante adicionada ao reservatório que alimentava o sistema, pode não ter sido suficiente para manter o $\mathrm{pH}$ próximo do valor desejado, entre 7 e 8 , ao longo da operação do BF do defintivo. Essas mudanças também podem ser a causa dos picos de alcalinidade total observado nas figuras 5.36 e 5.37, respectivamente.

A dispersão dos valores obtidos para o parâmetro pH na operação do Biofiltro Piloto está apresentada na figura 5.38. O valor do $\mathrm{pH}$ afluente ao sistema de reatores variou entre 6,5 e 7,3 para 75\% das amostras analisadas, enquanto que para esse mesmo percentual de amostras coletadas na saída do sistema o valor do $\mathrm{pH}$ esteve entre 6,5 e 7,4 .

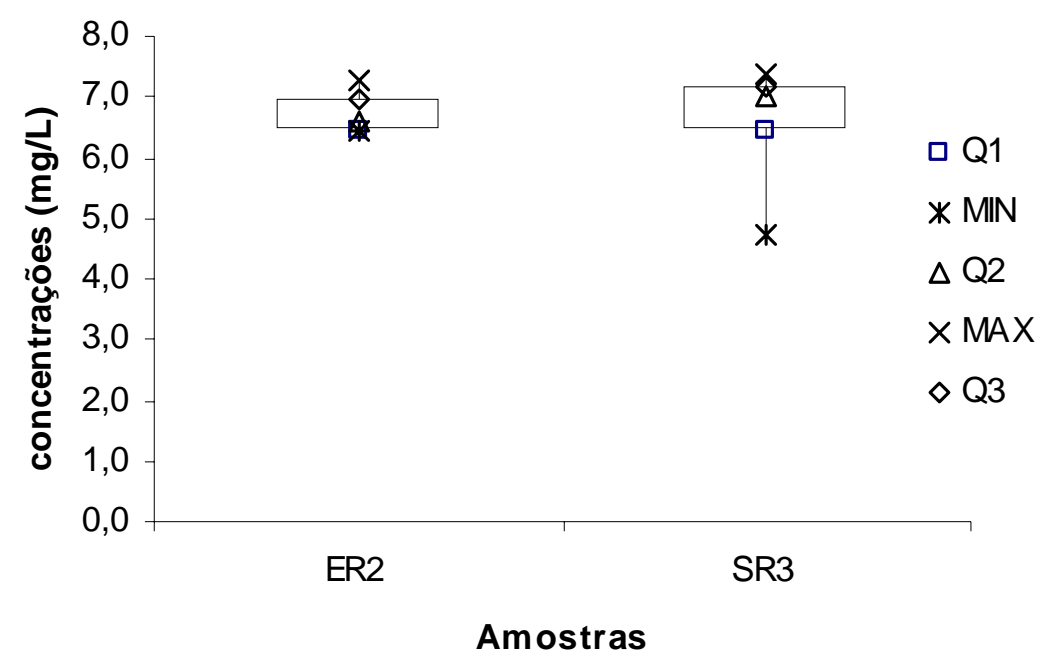

Figura 5.38 - Box-plot dos valores do pH obtidos na operação do Biofiltro Piloto.

É possível identificar, pela variação temporal dos valores de $\mathrm{pH}$ apresentada na figura 5.39, os pontos em que os valores do $\mathrm{pH}$ efluente foram menores que o afluente. Esse fato indica que a alcalinidade afluente ao sistema não era suficiente para manter o $\mathrm{pH}$ dentro do valor ótimo para as bactérias desnitrificantes, que segundo HENZE et al. (1997) deve estar entre 7 e 9. Porém, JIANPING et al. (2002), operando um reator de biomassa imobilizada, apontaram como faixa ótima para desnitrificação valores de $\mathrm{pH}$ entre 6,5 e 7,5. Essa variação foi praticamente a mesma observada na operação do 
Biofiltro Piloto. Portanto, a indisponibilidade de fonte de carbono pode ter sido o principal fator limitante da desnitrificação nessa fase da pesquisa.

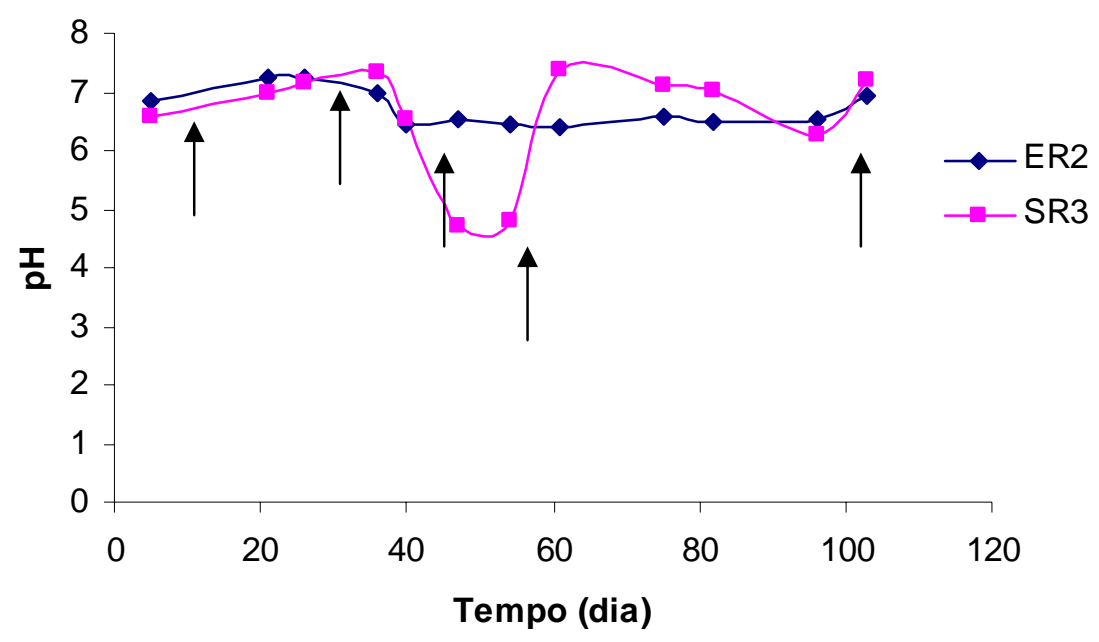

Figura 5.39 - Variação temporal dos valores do pH obtidos na operação do Biofiltro Piloto.

\subsubsection{Remoção de sólidos.}

Os resultados das análises para as variáveis sólidos totais (ST), sólidos totais fixos (SF), sólidos totais voláteis (SV), sólidos dissolvidos totais (SDT), sólidos dissolvidos fixos (SDF) e sólidos dissolvidos voláteis (SDV) e relações SV/ST, SF/SV e SDV/SDT estão apresentados na tabela 5.30 em valores, mínimo, máximo e média aritmética. A tabela apresenta ainda o número de amostras analisadas no período considerado.

Pela tabela 5.30 é possível verificar que as concentrações médias de sólidos totais, afluente e efluente ao Biofiltro Piloto foram, respectivamente, iguais a 425,8 e $359,3 \mathrm{mg} / \mathrm{L}$. Esses resultados revelam eficiência média de remoção desse parâmetro aproximadamente igual a 16\%. Essa baixa eficiência pode ser justificada pela relação $\mathrm{SF} / \mathrm{SV}$ que, segundo essa tabela, foram em média, iguais a 1,53 e 2,20, respectivamente, para os pontos amostrais de entrada e saída do sistema. Esses valores indicam alto percentual de material inerte. O aumento desse percentual, verificado na saída do sistema pode ser justificado pela estabilização do lodo acumulado nos reatores que não foi descartado durante a operação do Biofiltro Piloto. 
Tabela 5.30 - Valores médio, mínimo, máximo e numero de amostras analisadas para os parâmetros ST, SF, SV, SDT, SDF, SDV e relações SV/ST, SF/SV e SDV/SDT.

\begin{tabular}{c|cccccc}
\hline $\begin{array}{c}\text { Biofiltro } \\
\text { Piloto }\end{array}$ & \multicolumn{2}{|c}{ ST (mg/L) } & \multicolumn{2}{c}{ SF (mg/L) } & \multicolumn{2}{c}{ SV (mg/L) } \\
& ER2 & SR3 & ER2 & SR3 & ER2 & SR3 \\
\hline Média & 425,8 & 359,3 & 212,8 & 215,3 & 213,1 & 144,0 \\
Mínimo & 238,6 & 249,0 & 107,0 & 131,4 & 47,1 & 23,0 \\
Máximo & 951,4 & 476,0 & 442,9 & 278,6 & 508,6 & 239,0 \\
n & 11,0 & 11,0 & 11,0 & 11,0 & 11,0 & 11,0 \\
\hline Biofiltro & \multicolumn{2}{|c}{ SDT (mg/L) } & SDF $(\mathbf{m g} / \mathbf{L})$ & SDV (mg/L) \\
Piloto & ER2 & SR3 & ER2 & SR3 & ER2 & SR3 \\
\hline Média & 263,6 & 291,2 & 167,3 & 168,1 & 96,3 & 123,1 \\
Mínimo & 189,0 & 171,0 & 99,0 & 47,0 & 20,0 & 26,0 \\
Máximo & 342,9 & 475,7 & 250,0 & 242,9 & 160,0 & 235,7 \\
n & 11,0 & 11,0 & 11,0 & 11,0 & 11,0 & 11,0 \\
\hline Biofiltro & \multicolumn{2}{c}{ SV/ST } & \multicolumn{2}{c}{ SF/SV } & \multicolumn{2}{c}{ SDV/SDT } \\
Piloto & ER2 & SR3 & ER2 & SR3 & ER2 & SR3 \\
\hline Média & 0,47 & 0,39 & 1,53 & 2,20 & 0,36 & 0,42 \\
Mínimo & 0,17 & 0,09 & 0,42 & 0,98 & 0,11 & 0,15 \\
Máximo & 0,70 & 0,51 & 4,94 & 9,83 & 0,55 & 0,76 \\
n & 11,00 & 11,00 & 11,00 & 11,00 & 11,00 & 11,00 \\
\hline
\end{tabular}

Segundo dados da relação SV/ST apresentados na tabela 5.30 o percentual orgânico dos sólidos totais, afluente e efluente, respectivamente, foi em média igual a 47 e $39 \%$. Esses valores indicam baixa biodegradabilidade do esgoto efluente do reator UASB. Esse fato talvez tenha contribuído para limitar a desnitrificação do sistema uma vez que a biodisponibilidade de fonte de carbono orgânico para as bactérias desnitrificantes pode não ter sido suficiente para promover altas taxas de conversão de $\mathrm{N}-\mathrm{NO}_{3}{ }^{-}$a $\mathrm{N}_{2}$.

Comparando os resultados obtidos entre os sólidos totais e totais dissolvidos, apresentados na tabela 5.30, é possível estimar o percentual da matéria particulada afluente e efluente do sistema. Tal estimativa pode ser feita pela diferença entre os valores de sólidos totais e dissolvidos. Para concentração média de ST afluente ao BF o percentual médio estimado para a fração particulada foi de $38 \%$, enquanto para a concentração média efluente em ST, esse percentual foi estimado em 19\%. Essas 
estimativas apontam para o potencial de filtração conferido pelo material suporte utilizado no BF.

A estimativa da produção de lodo pode ser efetuada pela análise comparativa dos resultados apresentados, também na tabela 5.30, com os dados referentes à SV e SDV efluentes. Para concentração efluente média de SV igual a $144 \mathrm{mg} / \mathrm{L}$ o percentual médio de sólidos suspensos totais voláteis (SSV) foi estimado em 14,5\%, ou seja, 21 $\mathrm{mg} / \mathrm{L}$. Com esse resultado é possível estimar que, para carga volumétrica afluente média em sólidos suspensos igual a $0,195 \mathrm{~kg}$ de $\mathrm{SSV} / \mathrm{m}^{3} \mathrm{~d}$, a carga volumétrica média efluente foi igual $0,035 \mathrm{~kg}$ de SSV $/ \mathrm{m}^{3} \mathrm{~d}$.

A dispersão dos resultados apresentados na tabela 5.30 está representada nas figuras $5.40,5.41,5.42$ e 5.43 .

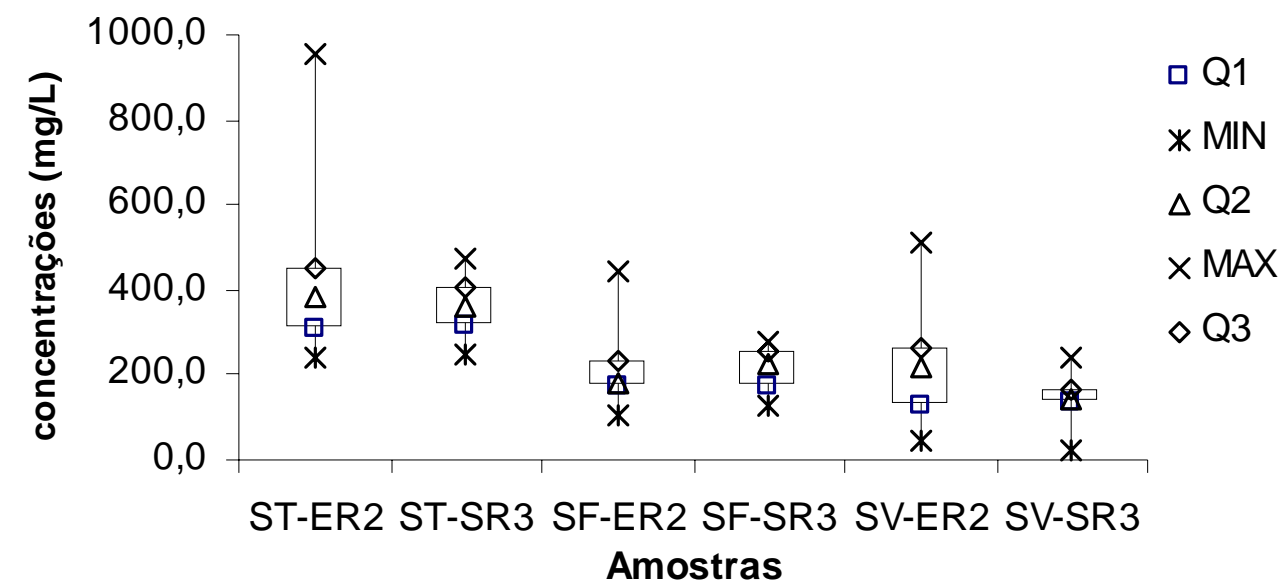

Figura 5.40 - Box-plot dos valores de ST, SF e SV obtidos na operação do Biofiltro Piloto.

A figura 5.40 mostra que a concentração de sólidos totais no afluente ao sistema variou entre 240 e $450 \mathrm{mg} / \mathrm{L}$ para um percentual de $75 \%$ das amostras analisadas, enquanto que para esse mesmo percentual a variação da concentração efluente de ST esteve entre 250 e $410 \mathrm{mg} / \mathrm{L}$. Esse resultado evidencia a baixa eficiência do sistema na remoção de ST. 


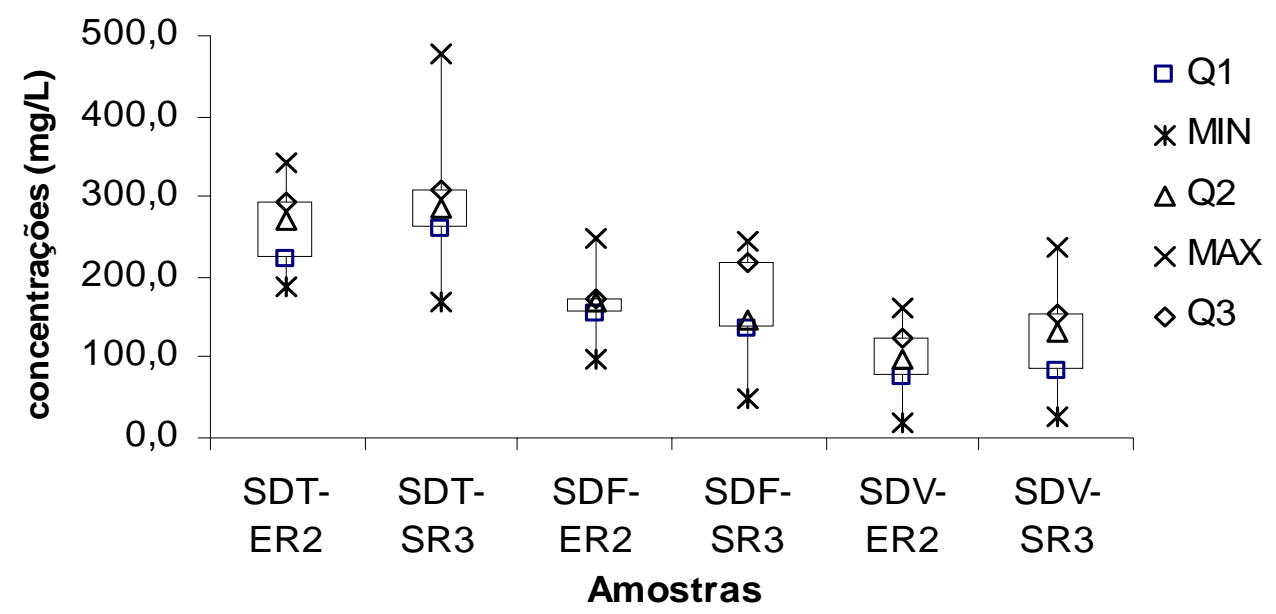

Figura 5.41 - Box-plot dos valores de SDT, SDF e SDV obtidos na operação do Biofiltro Piloto.

A concentração de SDT afluente ao sistema variou entre 220 e $290 \mathrm{mg} / \mathrm{L} \mathrm{em}$ $75 \%$ das amostras analisadas, como é possível verificar pela figura 5.41. A concentração efluente de SDT para o mesmo percentual de amostras variou entre 260 e $310 \mathrm{mg} / \mathrm{L}$ indicando um leve aumento na concentração dessa variável no efluente do BF. Esse aumento pode ser o resultado da estabilização do lodo acumulado no reator que não foi descartado durante o período experimental considerado.

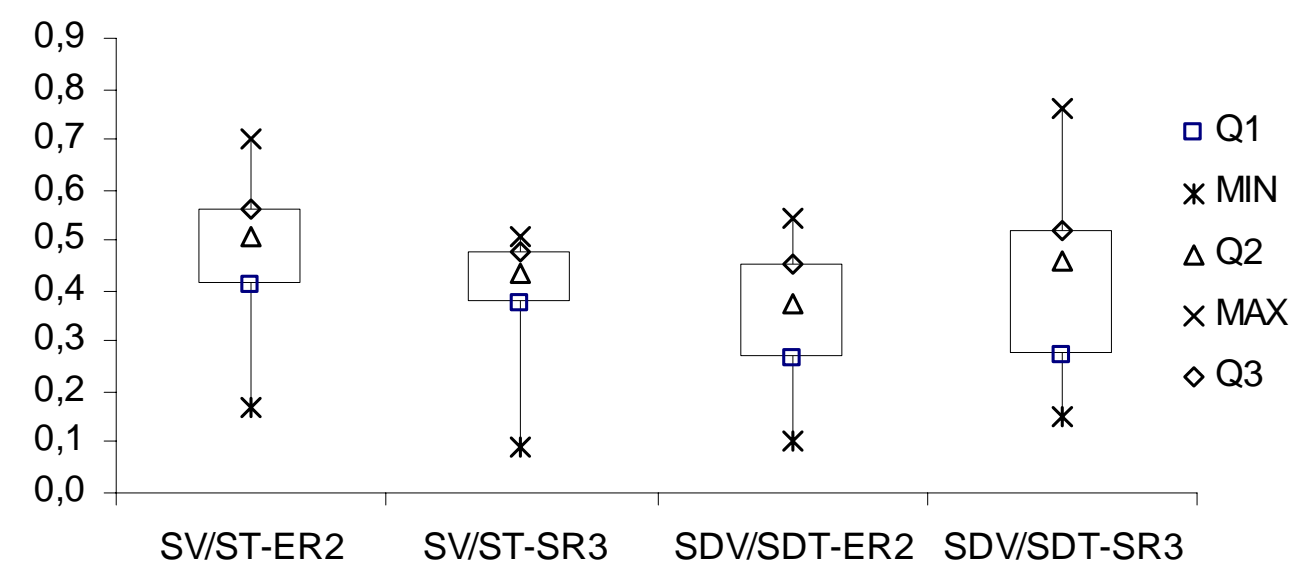

Figura 5.42 - Box-plot das relações SV/ST e SDV/SDT obtidas na operação do Biofiltro Piloto.

A fração orgânica dos valores de ST afluente ao BF esteve entre 17 e 56\% para $75 \%$ das amostras consideradas, como é possível observar na dispersão dos resultados da relação SV/ST apresentados na figura 5.42. Para esse mesmo percentual de 
amostras, a variação da fração orgânica dos valores de ST efluentes do sistema esteve entre 9 e $48 \%$.

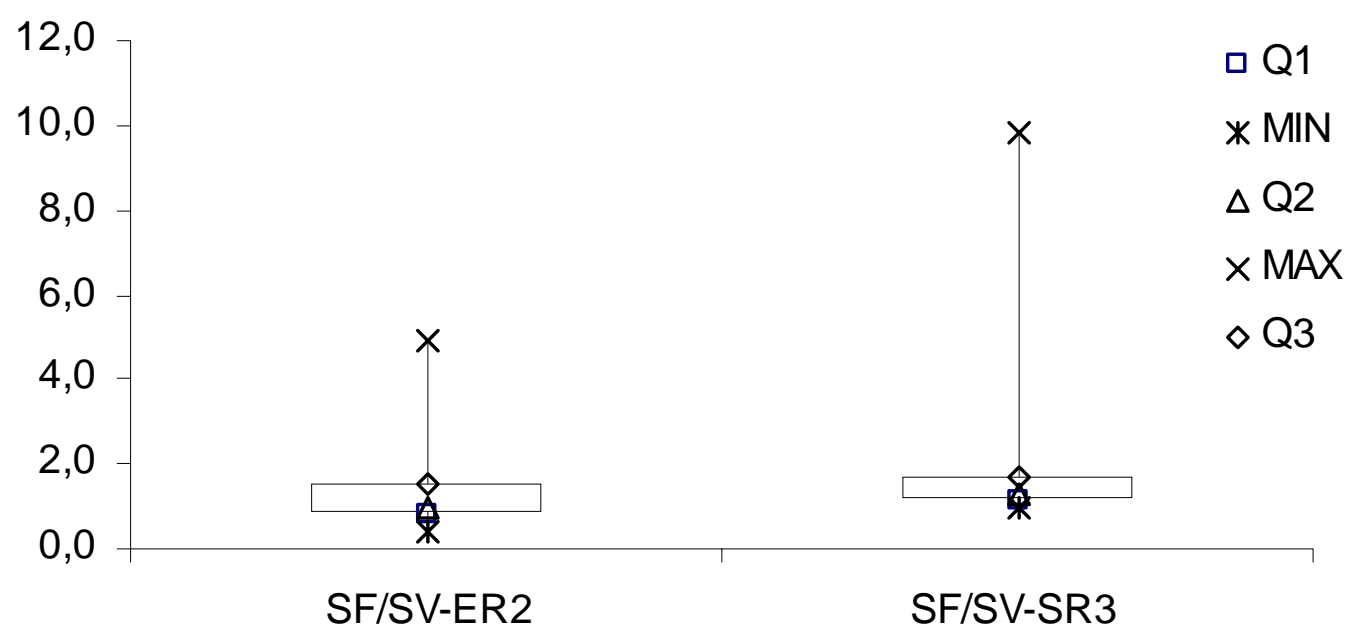

Figura 5.43 - Box-plot da relação SF/SV obtida na operação do Biofiltro Piloto.

A relação SF/SV afluente ao sistema variou entre 0,40 e 1,5 para um percentual de amostras igual a 75\%, enquanto que no esgoto efluente do sistema, a variação dessa relação esteve entre 1 e 1,7, para o mesmo percentual de amostras analisadas. Esses resultados indicam elevada quantidade de sólidos inertes tanto afluentes quanto efluentes ao BF.

5.4 Enquadramento do efluente produzido ao padrão de lançamento estabelecido pela legislação vigente.

Este capítulo foi dedicado a análise comparativa dos resultados encontrados ao longo de toda pesquisa, para verificar a eficiência dos sistemas propostos em atender aos padrões de lançamento da legislação ambiental vigente.

O padrão inicialmente adotado para análise comparativa dos resultados foi estabelecido pela resolução CONAMA no 357 de 17 de Março de 2005. Porém uma resolução complementar, CONAMA n 397 de 03 de Abril de 2008, estabeleceu no artigo $1^{\circ}$, parágrafo $7^{\circ}$, que o padrão de lançamento de nitrogênio amoniacal fixado em $20 \mathrm{mg} / \mathrm{L}$, pela resolução $\mathrm{n}^{\circ} 357$, não é mais aplicável a esgotos sanitários; no artigo $2^{\circ}$ porém, foi proposto a criação de um grupo de trabalho para estabelecer as condições e padrões para lançamento desses efluentes. 
Diante desse quadro, optou-se por continuar a adotar a resolução CONAMA n ${ }^{\circ}$ 357 de 17 de Março de 2005, para efeito comparativo dos resultados obtidos na pesquisa, já que em âmbito nacional não há, até o momento, qualquer padrão estabelecido pelos órgãos competentes.

Como o objetivo principal da pesquisa foi a busca de um sistema capaz de promover nitrificação e desnitrificação em um único reator, o parâmetro empregado na análise comparativa com o padrão apresentado pela legislação foi a concentração de nitrogênio amoniacal afluente e efluente dos BFs.

A figura 5.44 apresenta, para cada fase da pesquisa, as concentrações afluente e efluente em $\mathrm{N}_{-} \mathrm{NH}_{3}$, o respectivo padrão de lançamento indicado pela legislação ambiental e também os valores das concentrações de $\mathrm{N}_{-} \mathrm{NO}_{3}{ }^{-}$efluente.

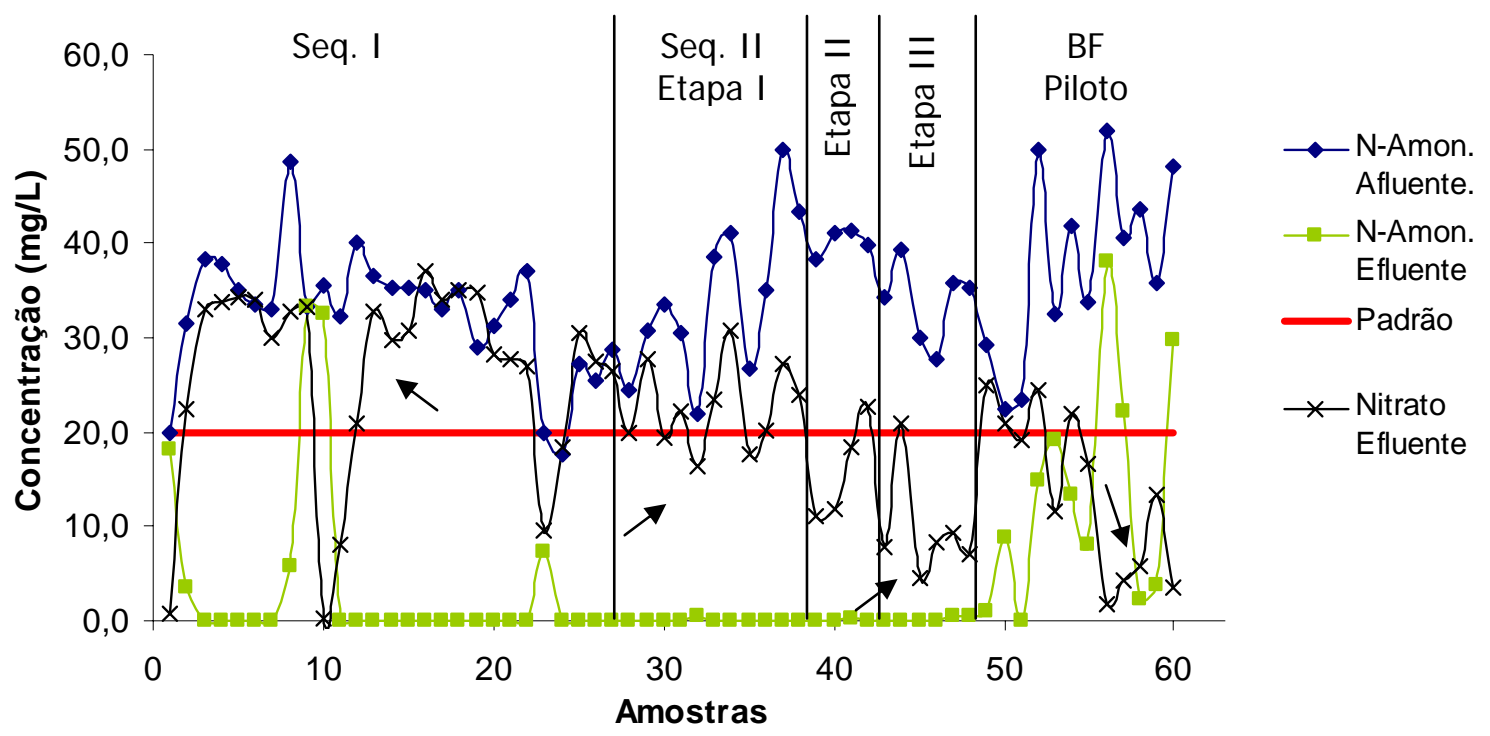

Figura 5.44 - Enquadramento do efluente produzido pelo sistema ao padrão de lançamento estabelecido pela resolução CONAMA 357/05.

A figura 5.44 revela que os sistemas operados ao longo da pesquisa foram adequados para pós-tratamento do efluente de UASB, no tocante ao enquadramento do efluente produzido ao padrão de $\mathrm{N}_{-} \mathrm{NH}_{3}$ estabelecido pela norma ambiental vigente. A maioria dos resultados de $\mathrm{N}-\mathrm{NH}_{3}$ efluentes, obtidos ao longo de toda pesquisa, estiveram abaixo do valor de $20 \mathrm{mg} / \mathrm{L}$, como padroniza tal norma.

Apesar da referida norma não estabelecer limites para lançamento de nitrato, a figura 5.39 apresenta, ainda, as concentrações de $\mathrm{N}^{-\mathrm{NO}_{3}}{ }^{-}$efluentes obtidas ao longo de todas as fases da pesquisa. Esses resultados foram ilustrados na figura, pois a conversão 
de nitrogênio amoniacal a nitrato não é suficiente para se falar em "remoção" de nitrogênio amoniacal. Segundo DAYLE et al. (1985) ${ }^{10}$ apud GÁLVEZ et al. (2003) nitrato em águas de abastecimento pode ser tóxico aos seres humanos, podendo causar uma séria doença conhecida como síndrome do bebê azul (Metahemoglobinemia). A portaria do ministério da saúde $n^{0} 518 / 2004$, estabelece o limite máximo de nitrato em águas de abastecimento em $10 \mathrm{mg} / \mathrm{L}$. Pela figura 5.40, portanto é possível verificar os pontos que atenderam aos padrões de lançamento e potabilidade, respectivamente.

\subsection{Exames microbiológicos.}

Exames microbiológicos, por microscopia óptica comum, foram realizados, ao final do período de investigação da etapa III da seqüência II, para se identificar os microrganismos presentes no lodo do sistema de reatores. Esses exames possibilitaram classificar o provável estágio de depuração do efluente do sistema.

As morfologias foram identificadas a partir da comparação com as descritas por JENKINS et al. (1993). As fotografias realizadas durante a microscopia estão apresentadas nas figuras 5.45, 5.46, 5.47, 5.48 e 5.49 .

Os microrganismos encontrados no lodo coletado no sistema de reatores operado na seqüência II - etapa III indicam elevado estágio de depuração.

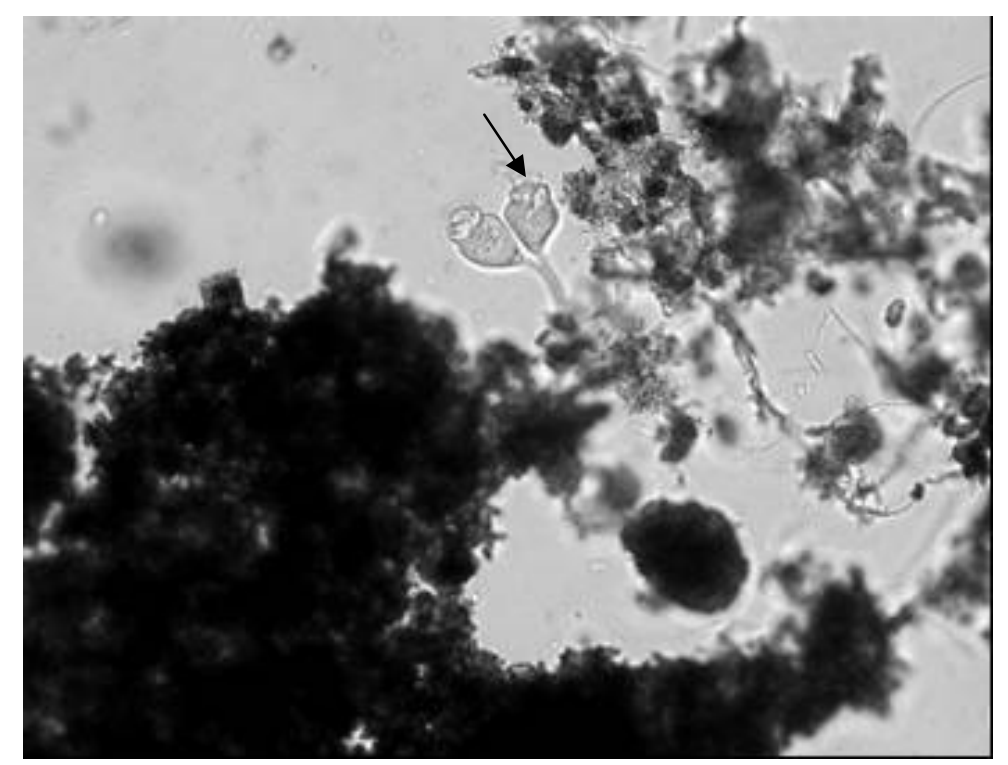

Figura 5.45 - Microscopia óptica comum do lodo coletado na etapa III da seqüência II: microrganismos ciliados fixos semelhantes a Epystilis sp.

\footnotetext{
${ }^{10}$ DAYLE, M.P., HERMAN, J.G., DYKSTRA, R. C. (1985). J. Free Radic. Med. p. 145.
} 


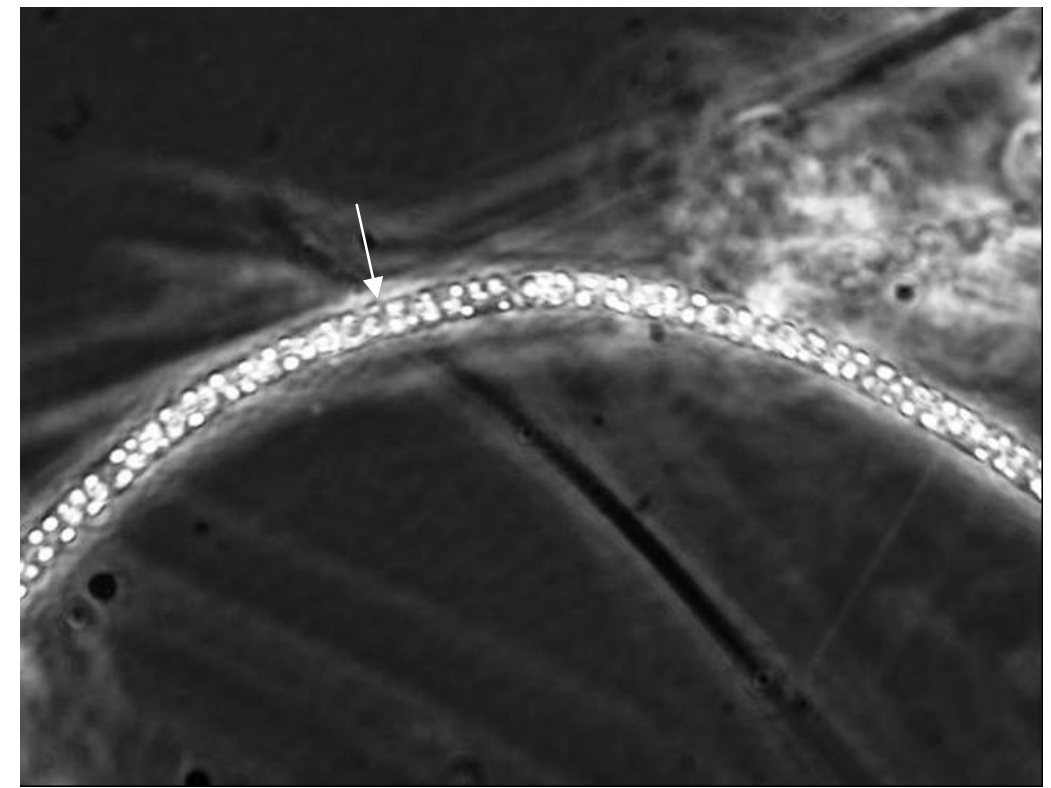

Figura 5.46 - Microscopia óptica comum do lodo coletado na etapa III da seqüência II: microrganismo filamentoso semelhante à Beggiatoa $\mathrm{sp}$.

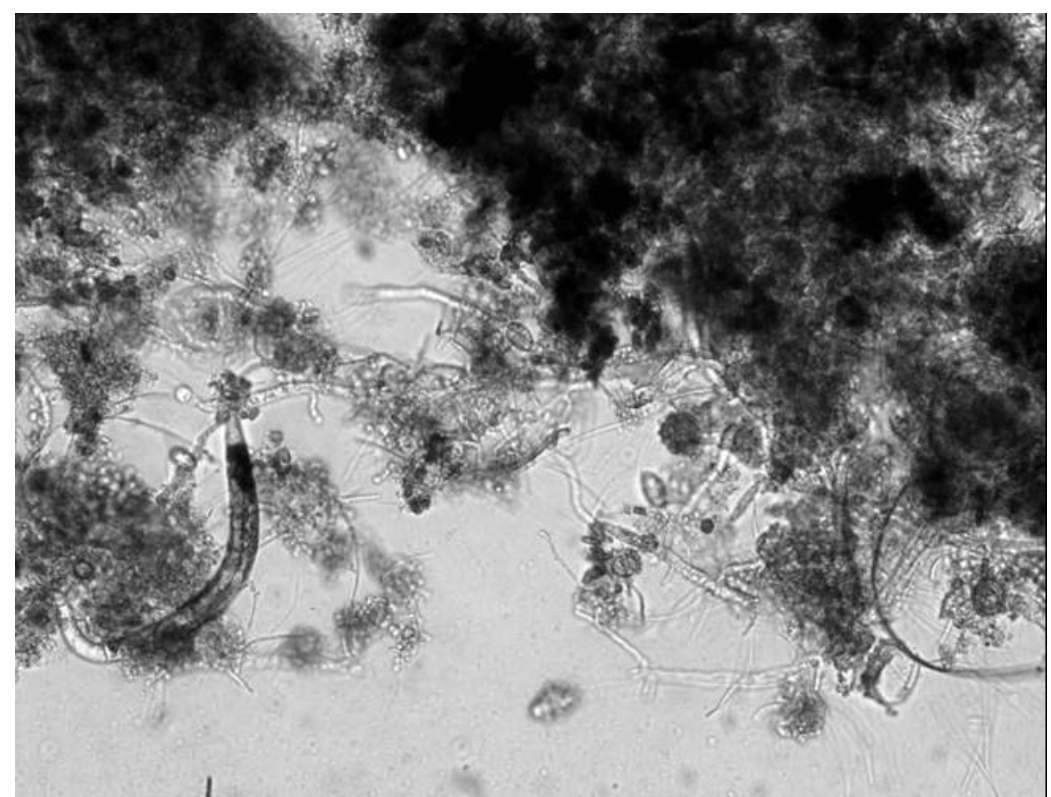

Figura 5.47 - Microscopia óptica comum do lodo coletado na etapa III da seqüência II: microrganismo Metazoário Nematóide. 


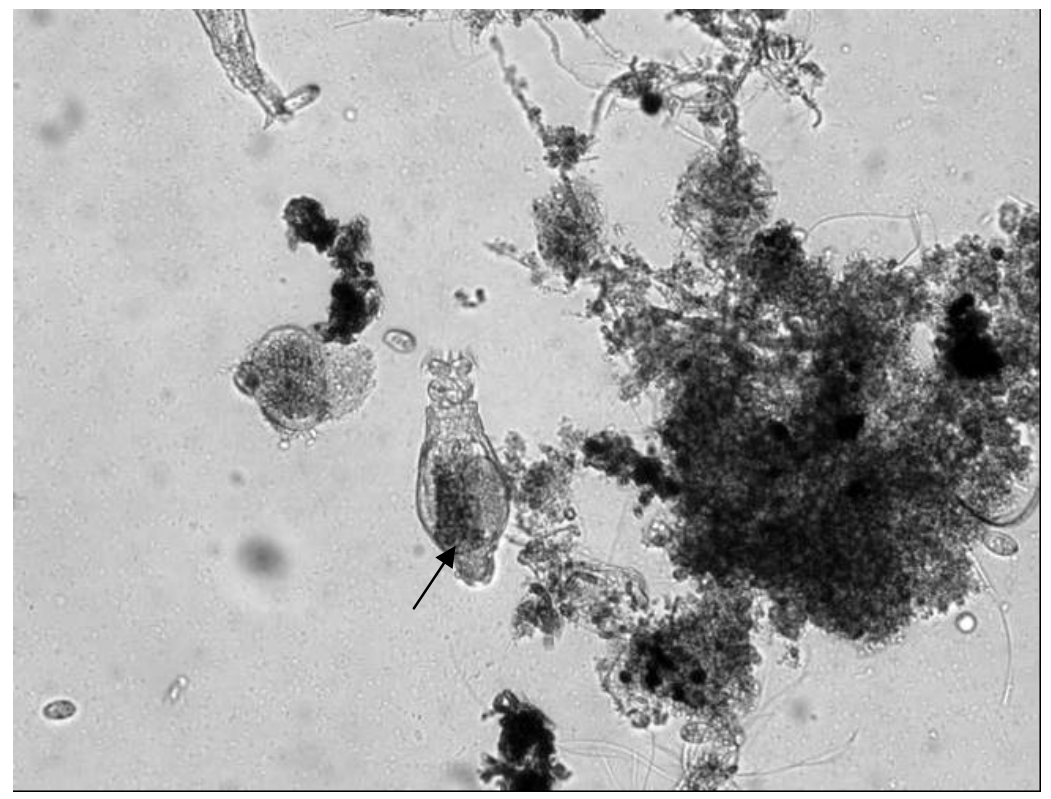

Figura 5.48 - Microscopia óptica comum do lodo coletado na etapa III da seqüência II: microrganismo Metazoário Rotífero.

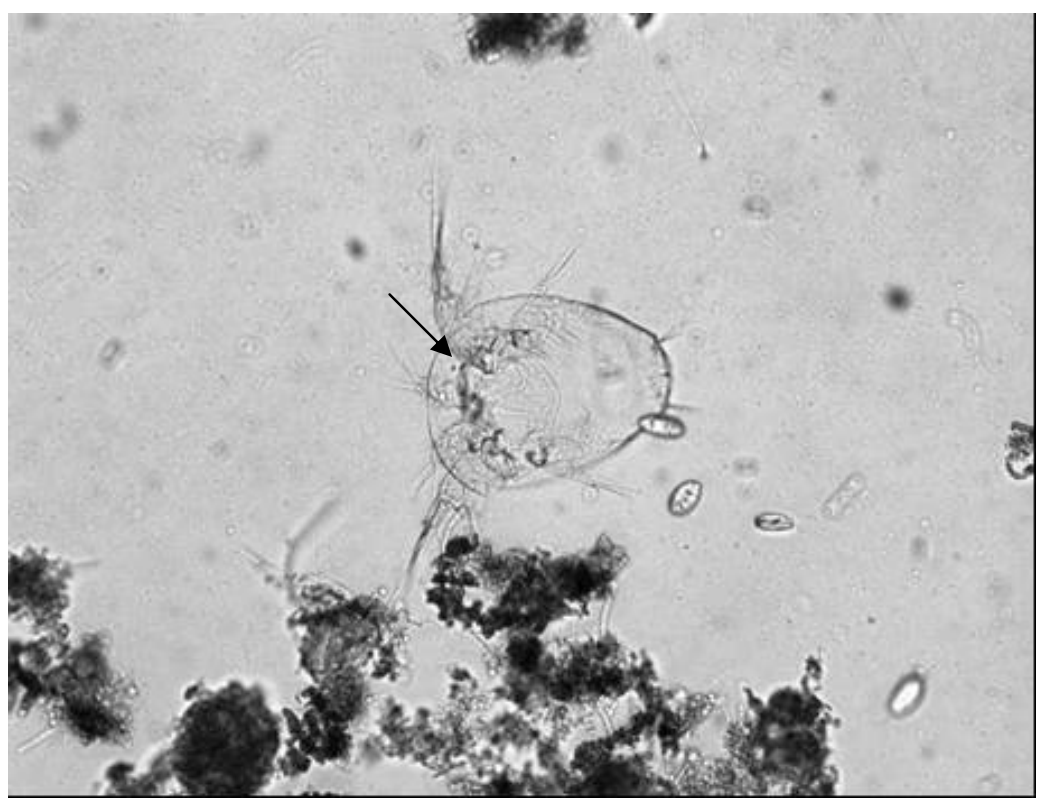

Figura 5.49 - Microscopia óptica comum do lodo coletado na etapa III da seqüência II: microrganismo Metazoário Ácaro. 


\section{Conclusões}

Os resultados obtidos com a operação dos sistemas de biofiltros empregados nas sequências I e II, respectivamente, bem como com a operação do biofitro investigado na configuração definitiva, permitem concluir que:

- Os dados relativos à remoção de matéria orgânica mostraram que o sistema proposto na seqüência I apresentou eficiência média de $94,5 \%$ em $\mathrm{DBO}_{5,20}$ e até $94,2 \%$ de remoção em DQO.

- Quanto à conversão de nitrogênio NTK e amoniacal o sistema de reatores operados na seqüência I apresentou alto potencial de conversão levando praticamente toda concentração de $(\mathrm{NTK})$ e $\left(\mathrm{N}-\mathrm{NH}_{3}\right)$ afluente a nitrato $\left(\mathrm{N}-\mathrm{NO}_{3}\right)$.

- O sistema operado na seqüência I apresentou baixo potencial em desnitrificação.

- A mudança efetuada na configuração do sistema da seqüência I para a seqüência II, visando aumento no potencial de desnitrificação, apresentou melhoria desse processo logo na operação da etapa I. Nessa etapa foi verificado, pelos resultados apresentados, um pequeno aumento no potencial de desnitrificação do sistema. O principal fator apontado para tal aumento, foi a recirculação efetuada entre os reatores $\mathrm{R} 1$ e R2, respectivamente, na razão $\mathrm{R}_{\mathrm{c}}$ igual 1 .

- O sistema de reatores operados na seqüência I também revelou alto potencial de remoção de sólidos suspensos com efluente bastante clarificado.

- O mudança dessa razão de 1 para 2,65, realizada na etapa II, resultou em aumento ainda mais significativo do potencial de desnitrificação do sistema.

- O potencial de desnitrificação nos reatores seqüenciais foi máximo na etapa III. O uso de $40 \%$, em volume, de esgoto bruto ao afluente do sistema como fonte de carbono, pode ter sido o principal fator responsável por tal eficiência.

- O aumento no potencial de desnitrificação observado da etapa II para etapa III, mostra que o efluente do reator UASB não era fonte de carbono adequada para as bactérias desnitrificantes. 
- Todas as etapas da seqüência II mostraram alto potencial de remoção da matéria orgânica carbonácea afluente ao sistema. Os resultados obtidos na etapa III mostraram que a eficiência média de remoção de DQO foi de 87,3\% com concentração média efluente do sistema igual a 19,6 mg/L.

- O sistema operado na etapa III revelou ser adequado para pós-tratamento do efluente do reator UASB, promovendo remoção das matérias orgânicas carbonácea e nitrogenada, dentro dos padrões estabelecidos pela norma, e também serviu como base tecnológica para construção e operação da configuração definitiva do BF.

- O biofiltro na configuração definitiva mostrou alto potencial na remoção da matéria orgânica em DQO, revelando capacidade para suportar altas concentrações afluentes como observadas durante sua operação.

- O objetivo principal da pesquisa que era obter um sistema capaz de promover nitrificação e desnitrificação em único sistema parece ter sido alcançado como mostram os resultados obtidos na operação do Biofiltro Piloto. Apesar da série de problemas encontrados durante a operação desse sistema, a eficiência de conversão de $\mathrm{N}^{-\mathrm{NH}_{3}}$ esteve dentro do padrão de lançamento estabelecido pela resolução CONAMA 357, em quase todas as amostras investigadas nesse período.

- O Biofiltro Piloto revelou ter, portanto, potencial para ser utilizado como unidade de pós-tratamento para efluente de reator UASB, empregado no tratamento de esgoto sanitário, apresentando as seguintes vantagens: alto potencial para suportar sobrecargas orgânicas, compacidade (conferindo versatilidade na instalação em regiões com pouca disponibilidade de área de implantação), nitrificação e desnitrificação em um único sistema (resultando em conversão total de $\mathrm{N}_{-} \mathrm{NH}_{3}$ a $\mathrm{N}_{2}$ ) e baixa produção de lodo (conferindo economia com sistema de tratamento e disposição desse lodo). 


\section{Recomendações}

Devido a problemas operacionais apontados anteriormente, o potencial de póstratamento do Biofiltro Piloto não foi devidamente explorado nessa pesquisa. Novas investigações, portanto, devem ser conduzidas de acordo com as seguintes recomendações:

- Operar o BF dentro das condições operacionais estabelecidas na etapa III $\left(\mathrm{R}_{\mathrm{c}}\right.$ igual a 2,65 e esgoto sanitário bruto como fonte de carbono) até que o sistema entre em equilíbrio dinâmico aparente.

- Efetuar descarte periódico do lodo acumulado no fundo dos reatores com sua respectiva quantificação e caracterização.

- Otimizar a quantidade de ar comprimido fornecido ao sistema até o mínimo valor possível, sem que os processos que dependem de OD sejam prejudicados. Essa quantidade pode ser tal que, promova acúmulo de nitrito no sistema favorencedo a desnitrificação por via curta na fase anóxica do sistema.

- Empregar, juntamente com o esgoto sanitário bruto, uma fonte complementar de carbono para melhorar a biodisponibilidade dessa aos microrganismos desnitrificantes.

- Verificar o potencial do sistema sob altas concentrações de nitrogênio amoniacal para uma possível aplicação no tratamento de efluentes industriais. 


\section{Referências Bibliográficas}

APHA, AWWA; WPCF (1995). Standard methods for examination of water and wastewater. 19th.Ed., American Public Health Association, American Water Works Association, Water Environment Federation, Washington DC, USA.

ARAVINTHAN, V.; TAKIZAWA, S.; FUJITA, K.; KOMATSU, K. (1998). Factors affecting nitrogen removal from domestic wastewater using immobilized bacteria. Water Science and Technology. v. 38, n. 1, p. 193-202.

AUN, M. V. (2007). Estudo da remoção de nitrogênio via nitrito e via nitrato me sistema de lodos ativados alimentos por despejos com alta concentração de fenol. Tese de Doutorado - Escola Politécnica de São Paulo - USP - São Paulo, 224p.

BARBER, W. P.; STUCKEY, D. C. (2000). Nitrogen removal in a modified anaerobic baffled reactor (ABR): 1, denitrification. Water Research. v. 34, n. 9, p. 2413-2422.

BODÍK, I.; KRATOCHVIL, K.; GÁSPARIKOVA, E.; HUTNAN, M. (2001). Nitrogen removal in an anaerobic baffled filter reactor with aerobic post-treatment. Bioresource Technology. n. 86, p. 79-84.

BRASIL. Ministério da Saúde. Portaria N518/ GM de 25 de março de 2004. Disponível em: <http://dtr2001.saude.gov.br/sas/PORTARIAS/Port2004/GM/GM518.htm.> Acesso em: 14 set 2008.

CALLADO, N. H.; FORESTI, E. (2000). Ensaio de atividade desnitrificante utilizando diferentes fontes de carbono. Disponível em:

<www.bvsde.paho.org/bvsacd/sibesa6/ciocho.pdf.>. Acesso em: 02 set. 2008.

CAMPOS, J. R., (1989). Remoção de DQO e de nitrogênio em um sistema de três reatores biológicos de filme fixo em série. Tese de Livre Docência - Escola de Engenharia de São Carlos - USP- São Carlos, 295p.

CAMPOS, J.R. et al. (1999). Tratamento de esgotos sanitários por processo anaeróbio e disposição controlada no solo. Rio de Janeiro - RJ. ABES - Projeto PROSAB.

CARRERA, J.; VICENT, T.; LAFUENTE, J. (2004). Effect of influent COD/N ratio on biological nitrogen removal (BNR) from high-strength ammonium industrial wastewater. Process Biochemistry. v. 39, n.12, p. 2035-2041.

CANZIANI, R. et. al. (1999). Nitrogen removal in fixed-bed submerged biofilters without backwashin. Water Science and Technology. v. 40, p. 145-152. 
ÇEÇEN, F. (1996). Investigation of partial and full nitrification characteristics of fertilizer wastewaters in a submerged biofilm reactor.Water Science and Technology. v.34, n.11, p. 77-85.

CHERNICHARO, C. A. L. (2001). Pós-tratamento de efluentes de reatores anaeróbios por reatores com biofilme. In: Pós-tratamento de efluentes de reatores anaeróbios. Belo Horizonte - MG. - Projeto PROSAB.

CHIE-CHIEN T.; THOMAS, G. P.; KOOPMAN, B. (1998). Effect of influent chemical oxygen demand to nitrogen ration on a partial nitrification/complete denitrification process. Water Research. v. 32, n.1, p. 165-173.

CHUI, P.C.; TERASHIMA, Y.; TAY, J.H.; OZAKI, H. (1996). Performance of a partly aerated biofilter in the removal of nitrogen. Water Science and Technology. v. 34, p.187-194.

CONAMA. Resolução n ${ }^{0} 357$ de 17 março de 2005. Disponível em: <www.mma.gov.br/port/conama/res/res05/res35705.pdf.> Acesso em: 11 set 2008.

CROLL, B. T.; HAYES, C. R. (1988). Nitrate and water supplies in the United Kingdom. Environmental Pollution. v. 50, p. 163-187.

DAVIDSON, J.; HELWIG, N.; SUMMERFELTA, S.T. (2008). Fluidized sand biofilters used to remove ammonia, biochemical oxygen demand, total coliform bacteria, and suspended solids from an intensive aquaculture effluent. Aquacultural Engineering. v.39, p. 6-15.

DINÇER, A. R.; KARGI, F. (2000). Kinetics of sequential nitrification and denitrification processes. Enzyme and Microbial Technology. v. 27, n. 1-2, p. 37-42.

FDZ-POLANCO, F.; MÉNDEZ, E.; URUEÑA, M. A.; VILLAVERDE, S. M.; GARCÍA, P. A. (2000). Spatial distribution of heterotrophs and nitrifiers in a submerged biofilter for nitrification. Water Research.v.34, n.16, p. 4081-4089.

GÁLVEZ, J. M.; GÓMEZ, M. A.; HONTORIA, E.; GONZÁLEZ-LÓPEZ, J. (2003). Influence of hydraulic loading and air flowrate on urban wastewater nitrogen removal with a submerged fixed-film reactor. Journal of Hazardous. v. 101, p. 219-229.

GARBOSSA, L. H. P. (2003) desenvolvimento e avaliação de sistema de leito fixo radial seguido de reator anóxico horizontal para remoção de matéria orgânica e nitrogênio de esgoto sanitário. Dissertação de Mestrado- Escola de Engenharia de São Carlos - USP- São Carlos,100p. 
GARBOSSA, L. H. P. (2006). Avaliação de sistemas anaeróbio-aeróbio com biomassa imobilizada para remoção de matéria carbonácea e nitrogênio de esgoto sanitário e uso de biogás na desnitrificação. Tese de Doutorado Escola de Engenharia de São Carlos - USP- São Carlos, 125p.

GÓMEZ, M. A.; GONZÁLEZ-LÓPEZ, J.; HONTORIA-GARCÍA, E. (2000). Influence of carbon source on nitrate removal of contaminated groundwater in a denitrifying submerged filter. Journal of Hazardous Materials. v. 80, p. 69-80.

GONÇALVES, R. F. et. al.(1998). Association of a UASB reactor and a submerged aerated biofilter for domestic sewage treatment. Water Science and Technology., v. 38, p. 189-195.

GRUNDITZ, C.; DALHAMMAR, G. (2000). Development of nitrification inhibition assays using pure cultures of nitrosomonas and nitrobacter. Water Research. v. 35, n.2, p. $433-440$.

GUO, H.; ZHOU, J.; SU, J.; ZHANG, Z.; (2005). Integration of nitrification and denitrification in airlift bioreactor. Biochemical Engineering Journal. v. 23, p. 57-62.

HAMAKRISHNANA, A.; GUPTA, S. K. (2008). Effect of COD/NO${ }_{3}{ }^{-}-\mathrm{N}$ ratio on the performance of a hybrid UASB reactor treating phenolic wastewater. Desalination. v. 232, p. 128-138.

HENZE, M. (1997). Wastewater treatment : biological and chemical processes. 2.ed. Berlim: Springer Verlag. 383p.

IAMAMOTO, C. Y. (2006). Remoção de nitrogênio de águas residuárias com elevada concentração de nitrogênio amoniacal em reator com biomassa em suspensão operado em bateladas seqüenciais e aeração intermitente. Tese de Doutorado - Escola de Engenharia de São Carlos - USP- São Carlos, 157p.

JENKINS, D. et al. (1993). Manual on the causes and control of activated sludge bulking and foaming. 2.ed., USA: Library of Congress Cataloging in Publication date. $193 p$.

KOENIG, A.; LIU, L. H. (2001). Kinetic model of autotrophic denitrification in sulphur packed-bed reactors. Water Research. v.35, n. 8, p. 1969-1978.

LI, Y. Z.; HE, Y. L.; OHANDJA, D.G.; JI, J.; LI, J.F.; ZHOU, T. (2008). Simultaneous nitrification-denitrification achieved by an innovative internal-loop airlift MBR:

Comparative study. Bioresource Technology. v. 99, n.13, p. 5867-5872.

LING, J. e CHEN, S. (2005). Impact of organic carbon on nitrification performance of different biofilters. Aquacultural Engineering. v. 33, n. 2, p. 150-162. 
MADIGAN, M. T. et al. (1996). Brock biology of microorganisms. 8.ed. USA- New Jersey: Prentice Hall. 1110p.

MANN, A. T.; MENDOZA-ESPINOSA, L.; STEPHENSON, T. (1999). Performance of floating and sunken media biological aerated filters under unsteady state conditions. Water Research. v.33, n. 4, p.1108-1113.

MATSUMOTO, S.; TERADA, A.; TSUNEDA, S. (2007). Modeling of membraneaerated biofilm: Effects of $\mathrm{C} / \mathrm{N}$ ratio, biofilm thickness and surface loading of oxygen on feasibility of simultaneous nitrification and denitrification. Biochemical Engineering Journal. v.37, n. 1, p. 98-107.

METCALF; EDDY (1991) INC- Wastewater Engineer: Treatment, Disposal and Reuse. 3. ed. N. Y., Mc GRaw- Hill. 1334p.

METCALF; EDDY (2003) INC- Wastewater Engineer: Treatment, Disposal and Reuse. 4. ed. N. Y., Mc GRaw- Hill. 1819p.

MODIN, O.; FUKUSHIB, K.; NAKAJIMA, F.; YAMAMOTO, K. (2008). Performance of a membrane biofilm reactor for denitrification with methane. Bioresource Technology. v.99, p. 8054-8060.

MULDER, A.; VAN DE GRAAF, A.; ROBERTSON, L. A.; KUENEN, J. G. (1995). Anaerobic ammonium oxidation discovered in a denitrifying fluidized bed reactor. FEMS Microbiology Ecology. v. 16, n.3, p. 177-183.

OKABE, S.; OOZAWA, Y.; HIRATA, K.; WATANABE, Y. (1996). Relationship between population dynamics of nitrifiers in biofilms and reactor performance at various C:N ratios. Water Research. v. 30, n.7, p. 1563-1572.

QI, R.; YANG, K.; YU, Z. (2007).Treatment of coke plant wastewater by SND fixed biofilm hybrid system. Journal of Environmental Sciences. v. 19, n. 2, p.153-159.

QIN, L. e LIU, Y. (2006). Aerobic granulation for organic carbon and nitrogen removal in alternating aerobic-anaerobic sequencing batch reactor. Chemosphere. v. 63, n. 6, p. 926-933.

RAMOS A.F.; GÓMEZA M. A., HONTORIA E.; GONZÁLEZ-LÓPEZ J. (2007). Biological nitrogen and phenol removal from saline industrial wastewater by submerged fixed-film reactor. Journal of Hazardous Materials. v. 142, p.175-183.

REYES-AVILA, J.; RAZO-FLORES, E.; GÓMEZ, J. (2004). Simultaneous biological removal of nitrogen, carbon and sulfur by denitrification. Water Research. v. 38, n. 1415, p. 3313-3321. 
RODRÍGUEZ, J. A., (2006). Filtro biológico aeróbio/anóxico para remoção de nitrogênio de efluentes de reatores UASB. Tese de Doutorado - Escola de Engenharia de São Carlos - USP- São Carlos, 129p.

ROSTRON, W. M.; STUCKEY D. C.; YOUNG, A. A. (2001). Nitrification of high strength ammonia wastewaters: comparative study of immobilisation media. Water Research. v. 35, n. 5, p. 1169-1178.

RUIZ, G.; JEISON D.; RUBILAR, O.; CIUDAD, G.; CHAMY, R. (2006).

Nitrification-denitrification via nitrite accumulation for nitrogen removal from wastewaters. Bioresource Technology. v. 97, p. 330-335.

SÉGURET, F.; RACAULT, Y. (1998). Hydrodynamic behaviour of a full-scale submerged biofilter and its possible influence on performances.Water Science and Technology. v.38, n.8-9, p. 249-256.

SEN, P.; DENTEL, S. K. (1998). Simultaneous nitrification-denitrification in a fluidized bed reactor.Water Science and Technology. v. 38, n.1, p. 247-254.

SITÔNIO, C. P. (2001). Pós-tratamento de efluentes de reatores anaeróbios utilizando biofiltro aerado submerso. Dissertação de Mestrado - Escola de Engenharia de São Carlos - USP- São Carlos. 105p.

SOARES, L. V. (2003). Pós-tratamento de esgoto sanitário tratado em reator anaeróbio compartimentado utilizando biofiltro aerado submerso. Dissertação de Mestrado - Escola de Engenharia de São Carlos - USP- São Carlos. 181p.

SOUSA, T. J.; FORESTI, E. (1999). Utilização de lodo anaeróbio como fonte externa de carbono no processo de desnitrificação de águas residuárias. Revista Brasileira de Engenharia Agrícola e Ambiental. v.3, n.1, p.69-73.

TAWFIK, A.; KLAPWIJK, A.; EL-GOHARY, F.; LETTINGA, G. (2005). Potentials of using a rotating biological contactor $(\mathrm{RBC})$ for post-treatment of anaerobically pretreated domestic wastewater. Biochemical Engineering Journal. v. 25, n.1, p. 89-98.

THIRD, K. A.; GIBBS, B.; NEWLAND, M.; CORD-RUWISCHA, R. (2005). Longterm aeration management for improved N-removal via SND in a sequencing batch reactor. Water Research. v. 39, p. 3523-3530.

VAN LOOSDRECHT, M.C.M.; JETTEN, M.S.M. (1998). Microbiological conversions in nitrogen removal. Water Science and Technology.v.38, n.1, p. 1-7. 
VILLAVERDE, S.; FDZ-POLANCO, F.; GARCÍA, P. A. (2000). Nitrifying biofilm acclimation to free ammonia in submerged biofilters. Start-up influence. Water Research. v. 2, p. 602-610.

VILLAVERDE, S.; GARCÍA, P. A.; FDZ-POLANCO, F. (1997). Influence of pH over nitrifying biofilm activity in submerged biofilters. Water Research. v. 31, n. 5, p. 11801186.

VON SPERLING (1996) Princípios básicos de tratamento de Esgotos. Belo Horizonte: Departamento de Engenharia Sanitária e Ambiental-DESA - UFMG - 211p.

WALTER, B.; HAASE, C.; RÄBIGER, N. (2005). Combined nitrification/denitrification in a membrane reactor. Water Research. v. 39, p. 2781-2788.

WEISSENBACHER, N.; LODERER, C.; LENZ, K.; MAHNIK, S. N.; WETT, B.; FUERHACKER, M. (2007). NOx monitoring of a simultaneous nitrifying-denitrifying (SND) activated sludge plant at different oxidation reduction potentials. Water Research. v.41, n. 2, p. 397-405.

WESTERMAN, P. W.; BICUDO, J. R.; KANTARDJIEFF, A. (2000). Upflow biological aerated filters for the treatment of flushed swine manure. Bioresource Technology. v.74, n.3, p. 181-190.

WIJFFELS, R. H.; TRAMPER, J. (1995). Nitrification by immobilized cells. Enzyme and Microbial Technology. v.17, p. 482-492.

WU, C.; CHEN, Z.; LIU, X.; PENG, Y. (2007). Nitrification-denitrification via nitrite in SBR using real-time control strategy when treating domestic wastewater.

Biochemical Engineering Journal. v. 36, n. 2, p. 87-92.

YOO, H.; AHN, K.; LEE, H.; LEE, K.; KWAK, Y.; SONG, K. (1999).Nitrogen removal from synthetic wastewater by simultaneous nitrification and denitrification (SND) via nitrite in an intermittently-aerated reactor. Water Research. v.33, n.1, p. 145154. 